UNIVERSIDADE DE SÃO PAULO

FACULDADE DE ECONOMIA, ADMINISTRAÇÃO E CONTABILIDADE DEPARTAMENTO DE ADMINISTRAÇÃO

PROGRAMA DE MESTRADO PROFISSIONAL EM EMPREENDEDORISMO

MARCUS VINICIUS VIVONE

CONSULTOR EXTERNO COMO CATALISADOR DA TRANSFORMAÇÃO DE PROFISSIONAIS EM AGENTES INTERNOS DE MELHORIA CONTÍNUA

ORIENTADOR: PROF. DR. ALVAIR SILVEIRA TORRES JUNIOR

SÃO PAULO

2016 
Prof. Dr. Marco Antônio Zago

Reitor da Universidade de São Paulo

Prof. Dr. Adalberto Américo Fischmann

Diretor da Faculdade de Economia, Administração e Contabilidade

Prof. Dr. Roberto Sbragia

Chefe do Departamento de Administração

Prof. Dr. Martinho Isnard Ribeiro de Almeida

Coordenador do Programa do Mestrado Profissional em Empreendedorismo 


\title{
CONSULTOR EXTERNO COMO CATALISADOR DA TRANSFORMAÇÃO DE PROFISSIONAIS EM AGENTES INTERNOS DE MELHORIA CONTÍNUA
}

\author{
Dissertação apresentada ao Programa de Mestrado \\ Profissional em Empreendedorismo, da Faculdade de \\ Economia, Administração e Contabilidade da \\ Universidade de São Paulo, como requisito parcial para \\ obtenção do título de Mestre em Ciências.
}

Orientador: Prof. Dr. Alvair Silveira Torres Junior

Versão Corrigida

(versão original disponível na Biblioteca da Faculdade de Economia, Administração e Contabilidade)

SÃO PAULO 


\section{FICHA CATALOGRÁFICA}

Elaborada pela Seção de Processamento Técnico do SBD/FEA/USP

Vivone, Marcus Vinicius.

Consultor externo como catalisador da transformação de profissionais em agentes internos de melhoria contínua / Marcus Vinicius Vivone. São Paulo, 2016.

$187 \mathrm{p}$

Dissertação (Mestrado) - Universidade de São Paulo, 2016.

Orientador: Alvair Silveira Torres Junior

1. Eficiência organizacional. 2. Melhoria contínua. 3. Consultoria. 4. Agentes. I. Universidade de São Paulo. Faculdade de Economia, Administração e Contabilidade. II. Título.

CDD 658.409 
A Deus, aos meus pais, a minha esposa e a minha filha. 



\section{AGRADECIMENTOS}

Agradeço a minha esposa Miriam e filha Maria Luiza, pelo tempo em que abriram mão de minha presença, por seu amor e pelas palavras de motivação.

Agradeço aos meus pais, Rui e Rose, e a Odila, por serem um exemplo vivo de caráter, generosidade e cuidado com a família. Aos meus irmãos Eduardo e Ana Paula, por serem exatamente isso: irmãos. Me sinto muitíssimo privilegiado por ter vocês como família.

Agradeço aos meus colegas de trabalho, pelo compartilhar diário de experiências e conhecimentos.

Agradeço a todos os professores do programa de mestrado profissional em empreendedorismo da FEA. Em especial agradeço ao professor Martinho e a Fabiana pelo suporte e a incansável dedicação para alcançar excelência em cada aspecto do programa e nos tornar melhores profissionais e acadêmicos.

Agradeço aos meus colegas de mestrado, pela criação de um ambiente de cooperação e torcida mútua.

Finalmente, um agradecimento especial ao meu orientador, o professor Alvair pela sua abordagem de orientação construtiva na busca de produção de conhecimento relevante, um verdadeiro e sábio mentor. 

E conhecerão a verdade, e a verdade vos libertará.

Jesus Cristo. 



\section{RESUMO}

A implantação de um processo ou programa de melhoria contínua pode ser verificada amplamente no contexto organizacional. Para que produtos, processos e serviços sejam melhorados é necessária a realização de intervenções, usualmente denominadas projetos de melhoria. Os profissionais, membros da organização, devem estar aptos, disponíveis e engajados na identificação, seleção e condução de projetos de melhoria. O presente estudo visa identificar elementos relevantes para a transformação efetiva de profissionais, membros da organização, em agentes internos de melhoria. Uma pesquisa de campo, de caráter exploratório foi realizada, utilizando a metodologia de estudo de casos múltiplos. Foram pesquisadas três montadoras onde foram capacitados 410 agentes internos de melhoria durante os anos de 2012 e 2014. Dezesseis elementos foram identificados na revisão bibliográfica. As evidências de pesquisa de campo apontaram 7 elementos altamente relevantes, e 7 elementos moderadamente relevantes, que foram classificados em duas categorias: institucionalização de melhoria e agência humana. Recomendações à prática gerencial incluíram um modelo de análise de prontidão para melhoria contínua. Recomendações a teoria acadêmica incluíram a formulação de 4 elementos que não foram observados na revisão bibliográfica, mas tiveram papel significativo na transformação de agentes internos de melhoria.

Palavras-chaves: Eficiência organizacional; Melhoria contínua; Consultoria; Agentes. 


\begin{abstract}
The implementation of a continuous process or program can be broadly verified in the organizational context. In order to improve products, processes and services, it is necessary interventions, usually called improvement projects. The employees shall be qualified, available and committed in the identification, selection and implementation of improvement projects. This current study has the purpose to identify relevant elements for the effective transformation of employees into continuous improvement internal agents. This study is exploratory and a multiple case study research. Three automotive industries were researched which were qualified 410 improvement internal agents between 2012 e 2014. Sixteen elements were identified from bibliography review. Seven elements were classified with high relevancy and 7 with moderate relevancy from the evidenced from the field research. Recommendation to the managerial practice include a readiness review model for continuous improvement. Recommendation to the academic theory included the formulation of 4 new elements that did not come from the bibliography review, but had a significant role in the transformation of internal improvement agentes.
\end{abstract}

Keywords: Organizational efficiency; Continuous improvement; Consultancy; Agents. 


\section{LISTA DE ABREVIATURAS E SIGLAS}

DMAIC: Acrônimo da metodologia de solução de projeto seis sigma.

ISO: International Organization for Standardization

WCM: World Class Manufacturing 


\section{LISTA DE QUADROS}

Quadro 1 - Acompanhamento contínuo de projetos nas montadoras A e C.

Quadro 2 - Filtros utilizados na pesquisa de publicações sobre melhoria contínua.

Quadro 3 - Referencial teórico do presente estudo.

Quadro 4 - Enfoques de pesquisas sobre melhoria contínua.

Quadro 5 - Assertivas identificadas a partir do referencial teórico sobre obstáculos a melhoria contínua.

Quadro 6 - Assertivas identificadas a partir do referencial teórico sobre fatores críticos de sucesso para a melhoria contínua.

Quadro 7 - Assertivas identificadas a partir do referencial teórico sobre comprometimento com a melhoria contínua.

Quadro 8 - Assertivas identificadas a partir do referencial teórico sobre seleção e gerenciamento de projetos de melhoria contínua.

Quadro 9 - Assertivas identificadas a partir do referencial teórico sobre sustentação dos resultados alcançados com os projetos de melhoria.

Quadro 10 - Rotinas chaves da melhoria contínua segundo Bessant et al. (2001).

Quadro 11 - Indicadores de maturidade da melhoria contínua segundo Fryer et al. (2013). 
Quadro 12 - Modelo de Wu e Chen sobre maturidade da melhoria contínua.

Quadro 13 - Facilitadores e Habilidades em cada Nível de Maturidade.

Quadro 14 - Assertivas identificadas a partir do referencial teórico sobre modelos de maturidade para melhoria contínua.

Quadro 15 - Assertivas identificadas a partir do referencial teórico sobre melhoria contínua como uma capacidade organizacional estratégica.

Quadro 16 - Relação entre as proposições teóricas e as questões de pesquisa com Agentes internos (A), Gestores (G), Coordenadores (C) e Consultores externos (CE).

Quadro 17 - Critérios de classificação da aderência das proposições teóricas.

Quadro 18.1 - Análise de projetos realizados na Montadora A.

Quadro 18.2 - Análise de outras fontes de evidência observadas na Montadora A.

Quadro 19.1 - Análise de projetos realizados na Montadora B.

Quadro 19.2 - Análise de outras fontes de evidência observadas na Montadora B.

Quadro 20.1 - Análise de projetos realizados na Montadora C.

Quadro 20.2 - Análise de outras fontes de evidência observadas na Montadora C.

Quadro 21 - Resultados dos projetos nas três montadoras.

Quadro 22.1 - Análise e classificação da relevância da proposição teórica P1

Quadro 22.2 - Análise e classificação da relevância da proposição teórica P2

Quadro 22.3 - Análise e classificação da relevância da proposição teórica P3 
Quadro 22.4 - Análise e classificação da relevância da proposição teórica P4

Quadro 22.5 - Análise e classificação da relevância da proposição teórica P5

Quadro 22.6 - Análise e classificação da relevância da proposição teórica P6

Quadro 22.7 - Análise e classificação da relevância da proposição teórica P7

Quadro 22.8 - Análise e classificação da relevância da proposição teórica P8

Quadro 22.9 - Análise e classificação da relevância da proposição teórica P9

Quadro 22.10 - Análise e classificação da relevância da proposição teórica P10

Quadro 22.11 - Análise e classificação da relevância da proposição teórica P11

Quadro 22.12 - Análise e classificação da relevância da proposição teórica P12

Quadro 22.13 - Análise e classificação da relevância da proposição teórica P13

Quadro 22.14 - Análise e classificação da relevância da proposição teórica P14

Quadro 22.15 - Análise e classificação da relevância da proposição teórica P15

Quadro 22.16 - Análise e classificação da relevância da proposição teórica P16

Quadro 23.1 - Classificação da relevância da proposição teórica P1

Quadro 23.2 - Classificação da relevância da proposição teórica P2

Quadro 23.3 - Classificação da relevância da proposição teórica P3

Quadro 23.4 - Classificação da relevância da proposição teórica P4 
Quadro 23.5 - Classificação da relevância da proposição teórica P5

Quadro 23.6 - Classificação da relevância da proposição teórica P6

Quadro 23.7 - Classificação da relevância da proposição teórica P7

Quadro 23.8 - Classificação da relevância da proposição teórica P8

Quadro 23.9 - Classificação da relevância da proposição teórica P9

Quadro 23.10 - Classificação da relevância da proposição teórica P10

Quadro 23.11 - Classificação da relevância da proposição teórica P11

Quadro 23.12 - Classificação da relevância da proposição teórica P12

Quadro 23.13 - Classificação da relevância da proposição teórica P13

Quadro 23.14 - Classificação da relevância da proposição teórica P14

Quadro 23.15 - Classificação da relevância da proposição teórica P15

Quadro 23.16 - Classificação da relevância da proposição teórica P16

Quadro 24 - Achados da pesquisa de campo não ligados diretamente as proposições teóricas 


\section{LISTA DE ILUSTRAÇÕES}

Ilustração 1 - Diagrama da Estrutura do Trabalho.

Ilustração 2 - Institucionalização da melhoria contínua.

Ilustração 3 - Modelo de 3 estágios de McLean e Antony.

Ilustração 4 - Preditores da capacidade de melhoria contínua.

Ilustração 5 - Acompanhamento de projetos na Montadora A

Ilustração 6 - Acompanhamento de projetos na Montadora B

Ilustração 7 - Acompanhamento de projetos na Montadora C 


\section{SUMÁRIO}

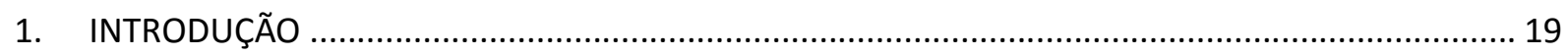

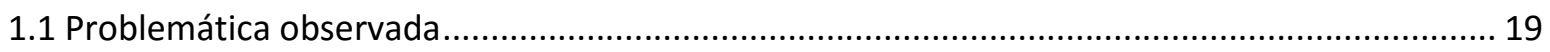

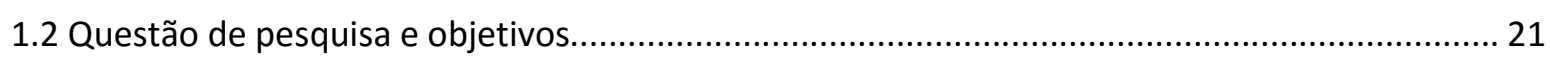

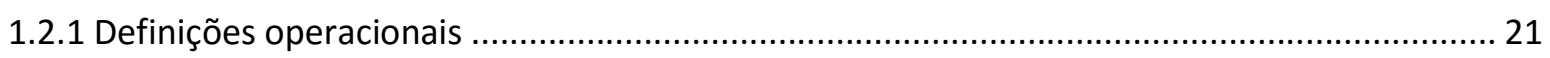

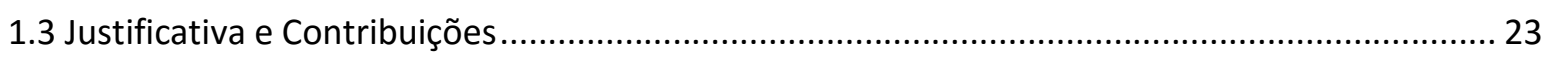

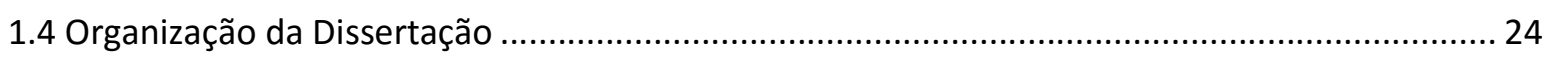

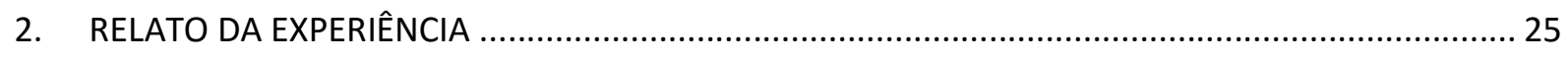

2.1 Consultoria externa para apoio ao programa de melhoria contínua.......................................... 25

2.2 Descrição das intervenções de capacitação entre 2012 e 2014 ................................................. 26

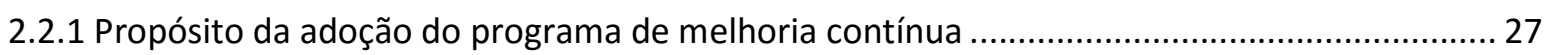

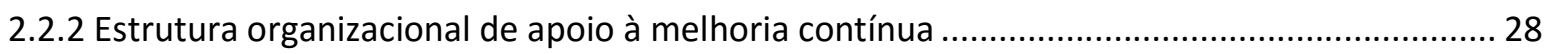

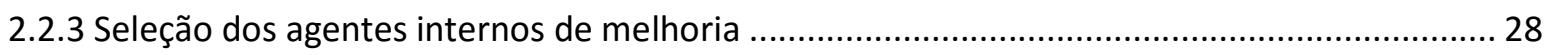

2.2.4 Competências requeridas e abordagem de aprendizagem ................................................... 29

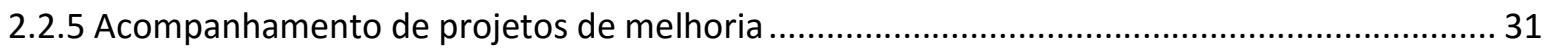

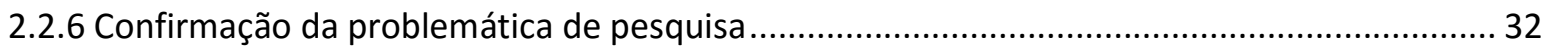

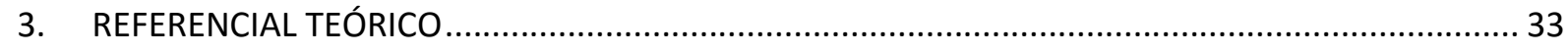

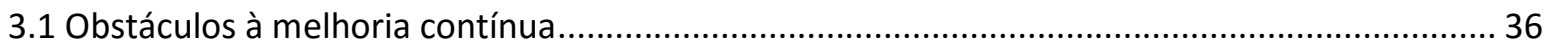

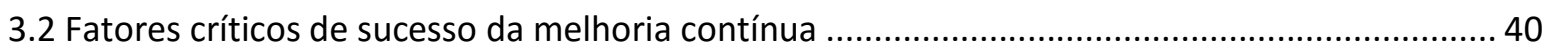

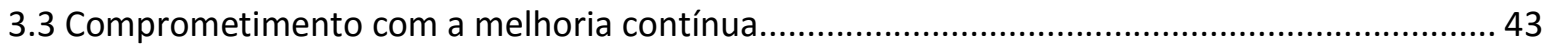

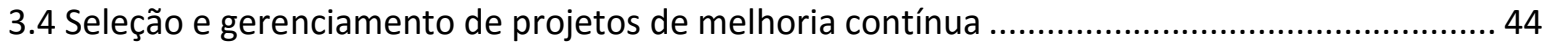

3.5 Sustentação dos resultados alcançados com os projetos de melhoria contínua ........................ 45

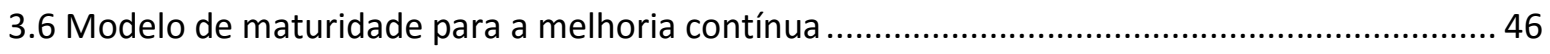

3.7 Melhoria contínua como uma capacidade organizacional estratégica......................................... 51

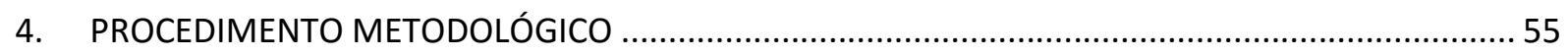

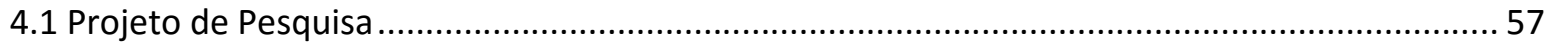

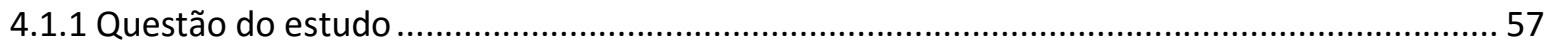

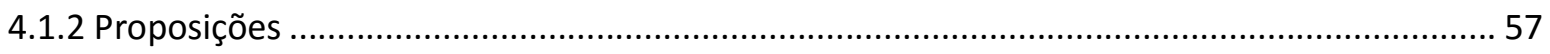

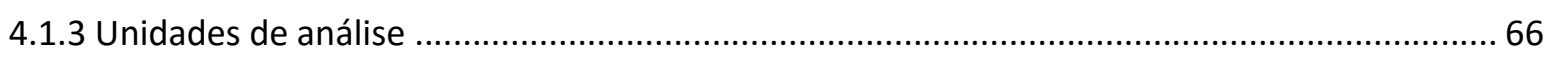

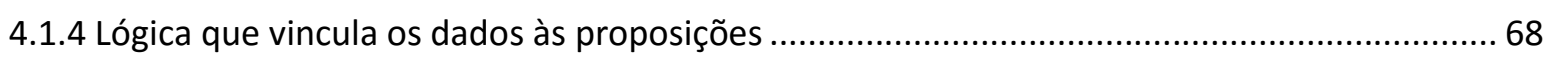

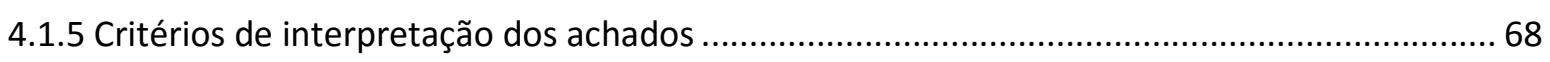

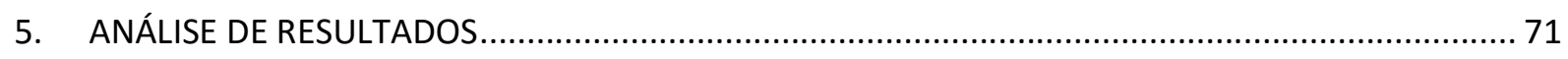

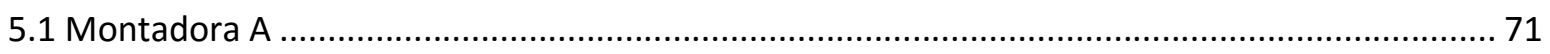


5.2 Montadora B

5.3 Montadora C... 85

5.4 Comparação dos resultados entre as montadoras 90

5.5 Análise e classificação da relevância das proposições teóricas .92

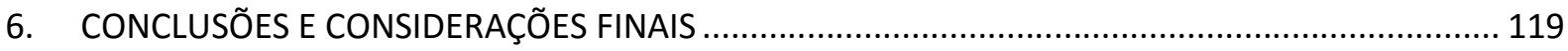

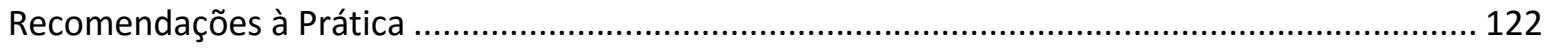

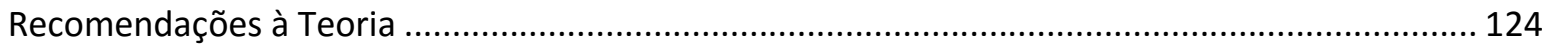

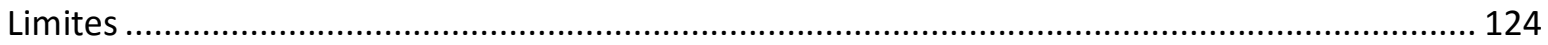

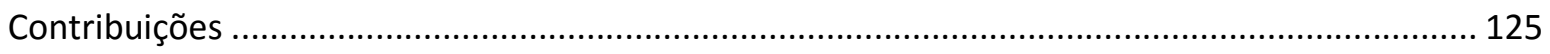

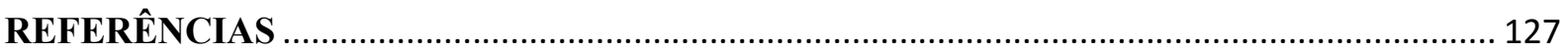

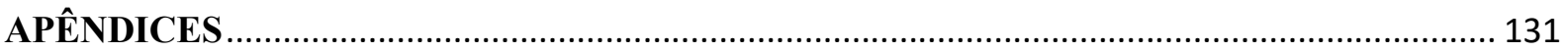

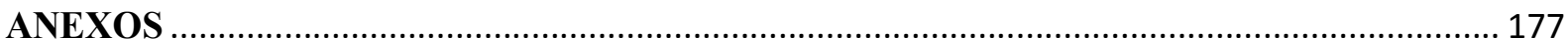




\section{INTRODUÇÃO}

$\mathrm{Na}$ indústria automobilística, setor produtivo caracterizado por intensa competição, a busca de ganhos de eficiência é um fator crítico de crescimento e de sobrevivência. Promover intervenções de melhoria de forma sistemática, a chamada melhoria contínua, tornou-se um daqueles poucos axiomas absolutos e de validade incontestável (Shah \& Ward, 2003). O clássico artigo de Bessant, Caffyn, Gilbert, Harding e Webb (1994) define a iniciativa de melhoria contínua como um processo de inovação incremental, contínuo, focado e perene em toda a organização.

A filosofia de melhoria contínua ganhou notoriedade com a divulgação dos estudos sobre práticas que explicaram a distinta e elevada competitividade das empresas japonesas na década de 1980. As iniciativas de melhoria contínua como programa seis sigma, manufatura classe mundial ou produção enxuta proliferaram mundialmente entre indústrias e empresas de serviço (Voss, 2005). A melhoria contínua é considerada uma prática essencial na estratégia de operações das principais montadoras globais. Ela é o elemento central das operações da Volvo no Volvo Production System-VPS, o princípio no General Motors Manufacturing System - GMS da GM, o pilar no World Class Manufacturing - WCM da Fiat Chrysler, o fundamento no modelo Toyota de produção, o cérebro do Nissan Production Way da Nissan, a cultura central da Mercedes-Benz no Truck Operating System-TOS, e a prática fundamental nos sistemas de produção das demais montadoras como Ford, VW, Audi, Scania, Honda, Ford, Caterpillar, MAN e em fornecedores automotivos como Benteler, Bosch, Cummins, Dana, Haldex, Hella, Valeo e ZF (Netland, 2013).

\subsection{Problemática observada}

Ao conciliar resultados de diversos estudos sobre o tema, Wu e Chen (2006) propõem um modelo de estruturação da atividade de melhoria contínua que tem como elemento comum o desenvolvimento de profissionais em métodos e ferramentas de solução de problemas. GarcíaSabater, Marín-García e Perelló-Marín (2012) confirmam a importância da capacitação profissional atestando que a falta de habilidades em solução de problemas é uma grande barreira à atividade de melhoria contínua. 
Um dos critérios de avaliação da eficácia do processo de capacitação, ora explícito, ora implícito, é que, ao concluí-lo, cada profissional passe a identificar e realizar projetos de melhoria para atingir objetivos de desempenho e resolver problemas crônicos. Trata-se, portanto, não apenas de apropriação de conhecimento metodológico, mas de viabilizar a transformação de profissionais em agentes internos de melhoria, ou seja, torná-los aptos, disponíveis e engajados na identificação, seleção e condução de projetos de melhoria.

O uso de consultorias externas para apoiar o processo de capacitação destes profissionais é uma prática comum. Dentro do modelo de intervenção adotado por algumas montadoras presentes no Brasil para transformar seus profissionais em agentes internos de melhoria contínua, o presente pesquisador atua como consultor externo responsável pelo desenho e realização do processo de capacitação. O papel de consultor possibilita a observação in loco antes, durante e após o término do processo de capacitação, onde se percebe que parte dos profissionais capacitados não realiza a condução de novos projetos de melhoria após sua qualificação inicial.

Daí surge a problemática investigada neste estudo: a simples prescrição e aplicação, por parte da consultoria externa, de boas práticas de treinamento em metodologias e ferramentas de solução de problemas não tem sido suficiente para perenizar a atividade de melhoria contínua no dia-a-dia de operações porque, em certa medida, a transformação esperada não ocorre sistematicamente.

Uma pesquisa conduzida por Pay (2008) descobriu que embora $74 \%$ das indústrias de manufatura americana adotou programas de manufatura enxuta, apenas $26 \%$ não estavam desapontadas com o progresso alcançado. Choo, Linderman e Schroeder (2007) desenvolveram um modelo conceitual que aponta como o grande fator de fracasso dos programas seis sigma a ausência da infraestrutura adequada para coordenar os múltiplos e concomitantes projetos de melhoria contínua, ou seja, enfatizando a importância do equilíbrio de esforços de desenvolvimento de habilidades técnicas e comportamentais. Tanto as pesquisas de campo quanto as proposições de modelos teórico conceituais abordam, de forma implícita ou explícita, a falta de efetividade das iniciativas de melhoria contínua, o que corrobora com a problemática central do presente estudo. 


\subsection{Questão de pesquisa e objetivos}

Da indagação sobre como tornar efetiva a intervenção de capacitação realizada pela consultoria, surgiu a seguinte questão de pesquisa:

- Quais elementos são relevantes na transformação efetiva de profissionais, membros da organização, em agentes internos de melhoria contínua, na indústria automobilística?

O objetivo geral deste estudo é descrever e analisar como tornar mais efetivos os esforços de transformação de profissionais, membros da organização, em agentes internos de melhoria na indústria automobilística. Os objetivos específicos para este trabalho são os seguintes:

a) Relatar as experiências de intervenções de capacitação dos agentes internos de melhoria.

b) Sumarizar os principais achados oriundos das teorias pesquisadas a fim de formar um referencial teórico.

c) Realizar um estudo de campo empírico nas empresas que passaram pelas intervenções de capacitação, coletando distintas fontes de evidência sobre os resultados e percepções dos processos de capacitação realizados.

d) Comparar, o referencial teórico e pesquisa de campo, a fim de identificar elementos relevantes na transformação efetiva de profissionais, membros da organização, em agentes internos de melhoria contínua da indústria automobilística.

e) Prover uma lista de recomendações à teoria acadêmica, ao identificar aderências e lacunas em relação ao referencial teórico.

f) Prover uma lista de recomendações à prática gerencial, ao propor novos cursos de ação para os casos estudados.

\subsubsection{Definições operacionais}

Adota-se aqui a definição operacional de melhoria contínua proposta por Yen-Tsang, Csillag e Siegler (2012):

A melhoria continua pode ser vista como uma capacidade da empresa na busca de atingimento uma meta organizacional particular, que pode ser a melhoria de desempenho organizacional nos indicadores de custo, entrega, qualidade e outros. Para que este propósito seja alcançado, atividades de melhoria contínua devem ser coordenadas e fundamentadas numa série de tarefas desenvolvidas pelos recursos organizacionais. O resultado da capacidade de melhoria continua não deveria ser ad-hoc, mas recorrente e intencional. 
As atividades de melhoria contínua citadas nesta definição compreendem intervenções de melhoria com o intuito de atingir metas através do estabelecimento de um novo processo ou modificação de um processo existente, bem como manter o processo existente dentro da estabilidade, ou seja, resolver problemas de forma a recuperar a estabilidade de processos organizacionais, usualmente através de ações que visam a restauração de padrões de trabalho Sanchez e Blanco (2014).

Dado que as intervenções de capacitação realizadas foram aplicadas em profissionais que desempenhavam outros papéis na organização, achou-se mais apropriado a adoção do termo transformação efetiva ao invés de formação. Ressalta-se que o conteúdo da transformação destes profissionais não é amplo, mas específico, na medida em que o resultado esperado é o surgimento de agentes internos que realizem projetos de melhoria de forma recorrente e intencional, concluído o processo de capacitação.

Empregamos aqui o termo agente, oriundo da teoria social cognitiva. Ser agente significa influenciar o próprio funcionamento e as circunstâncias de vida de modo intencional, contribuindo para as circunstâncias de sua vida, não sendo apenas produto dessas circunstâncias (Bandura, 2005).

Esforços de transformação de profissionais, membros da organização, em agentes internos de melhoria na indústria automobilística serão pesquisados em campo. Uma perspectiva contingencial (Sousa \& Voss, 2008) será utilizada para identificar aspectos relevantes.

Cabe aqui também uma definição operacional sobre esta perspectiva: enquanto a perspectiva universalista busca identificar as melhores práticas que possam ser aplicadas universalmente e afetem positivamente os resultados organizacionais intencionados, a perspectiva contingencial, a adotada neste estudo, considera como melhores práticas efetivas aquelas aplicáveis numa contingência organizacional bem definida, caracterizada por variáveis estratégicas, organizacionais e ambientais específicas (Martin-Alcazar, Romero-Fernandes, \& Sanchez-Gardey, 2005).

Dois eixos conceituais serão considerados na análise de resultados desta pesquisa: institucionalização, contemplando os processos e estrutura organizacional estabelecidos para 
reforçar a promoção da melhoria contínua; e a agência humana, abrangendo os fatores pessoais dos profissionais escolhidos para tornarem-se os agentes internos de melhoria. Propõe-se neste trabalho que a complementariedade e sincronismo entre estes dois eixos é o local onde ocorre a transformação de profissionais em agentes internos de melhoria, dentro das limitações de configuração organizacional de cada empresa automobilística estudada.

\subsection{Justificativa e Contribuições}

O presente estudo pretende prover contribuições para a teoria e para prática da melhoria contínua na indústria automobilística. A identificação e confirmação de elementos relevantes sobre a transformação efetiva de profissionais em agentes internos de melhoria contínua, citados ou não na literatura existente, será o legado para pesquisa acadêmica. A proposição de boas práticas para que esta transformação ocorra será o legado para a prática gerencial.

As iniciativas de melhoria contínua a serem investigadas e documentadas são aquelas com a intenção de desenvolver uma capacidade organizacional estratégica. Daí a importância de iluminar a questão da transformação de profissionais em agentes internos de melhoria, pois a aquisição de capacidades organizacionais passa pela capacidade de seus atores internos (Peng, Schroeder, \& Shah, 2008).

O escopo desta pesquisa inclui a análise de práticas de formação dos agentes de melhoria contínua durante os anos de 2012 a 2014 realizadas em três montadoras localizadas no Brasil. Nos três casos o pesquisador teve um papel de observador participante. A consultoria foi contratada pelas montadoras ao reconhecerem que não possuíam as habilidades ou os recursos necessários para promover esta transformação sem apoio externo.

Outro aspecto relevante é que nos três casos as montadoras manifestam, no mínimo, uma teoria esposada (Schein, 2010) com a filosofia de melhoria contínua. Desde suas matrizes e filiais em demais países, existem declarações formais, processos e estrutura para apoiar o programa de melhoria contínua, geralmente contemplado nos sistemas de produção corporativos. Isto é importante porque se elimina da amostra estudada um fator crítico que é a não intencionalidade de implantar um programa efetivo de melhoria contínua. 
De forma mais ampla, este estudo justifica-se por buscar a solução do hiato entre a teoria esposada e a teoria em uso (Argyris, 2003), representada pela diferença entre as propagadas declarações sobre a necessidade de estabelecimento de uma cultura de melhoria contínua e as barreiras observadas para sua institucionalização (Torres e Gatti, 2011).

\subsection{Organização da Dissertação}

Este trabalho de pesquisa está estruturado em capítulos, conforme ilustra a Ilustração $1 . \mathrm{Na}$ introdução apresenta-se a problemática, a questão e os objetivos de pesquisa. Em relato da experiência as observações do consultor oriundas de sua atividade profissional ligada a formação de agentes internos de melhoria contínua são descritas. A seção de referencial teórico tem como função identificar teorias administrativas que sejam relevantes para a análise dos casos por estarem ligadas ao conteúdo. O procedimento metodológico é descrito na seção seguinte, o que inclui as técnicas de coleta e triangulação de evidências. Na seção análise de resultados, é identificado o grau de ajuste entre a prática observada e o referencial teórico. Na seção conclusões e considerações finais são apresentadas as recomendações à prática e a teoria, a descrição de limitações e as contribuições obtidas com o estudo.

Ilustração 1 - Diagrama da Estrutura do Trabalho

\begin{tabular}{|c|c|c|}
\hline $\begin{array}{l}\text { 1. INTRODUÇÃO } \\
\text {. Qual é a questão e } \\
\text { objetivos de pesquisa? } \\
\text {. Porque é relevante? }\end{array}$ & $\begin{array}{l}\text { 2. RELATO DA } \\
\text { EXPERIÊNCIA } \\
\text {. Como ocorreram as } \\
\text { intervenções } \\
\text { realizadas? }\end{array}$ & $\begin{array}{l}\text { 3. REFERENCIAL } \\
\text { TEÓRICO } \\
\text {. Que teorias usar e o } \\
\text { que elas descrevem? }\end{array}$ \\
\hline
\end{tabular}

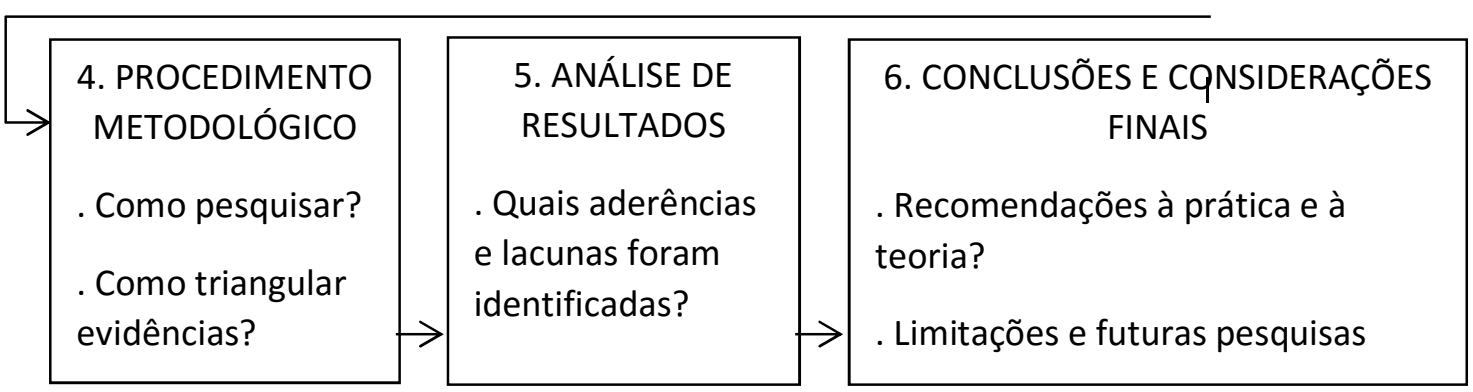

Fonte: Elaborado pelo autor 


\section{RELATO DA EXPERIÊNCIA}

\subsection{Consultoria externa para apoio ao programa de melhoria contínua}

A indústria automobilística tem desenvolvido seus próprios modelos de excelência em operações (Netland, 2013). O processo de formação de agentes internos de melhoria é uma etapa essencial na implantação destes modelos, pois a capacitação habilita os profissionais na realização de projetos cujos resultados colaboram com a busca da excelência operacional. Para suprir a demanda de informação e de qualificação dos agentes internos de melhoria surgiram várias empresas de prestação de serviços de consultoria e treinamento.

As intervenções aqui relatadas ocorreram entre os anos de 2012 a 2014 em três montadoras de veículos que contrataram serviços de uma consultoria externa para auxiliá-las na capacitação de seus profissionais. Trata-se de uma consultoria multinacional, com presença nos principais polos produtivos da indústria automobilística, especializada em desenvolver e desdobrar globalmente e de forma padronizada programas de certificação profissional. Estas características favorecem a sua contratação pelas montadoras, por assegurar consistência e alinhamento nos processos e critérios de capacitação e ao mesmo tempo adaptação às particularidades locais de cada planta e cadeia produtiva.

O presente pesquisador, desde o ano de 2003, ocupa nesta consultoria a função de Diretor de Desenvolvimento e participou ativamente do processo de capacitação dos agentes internos de melhoria nestas montadoras. As atividades realizadas pela consultoria podem ser divididas nas fases de desenvolvimento, implantação e acompanhamento do processo de capacitação. $\mathrm{O}$ presente pesquisador participou ativamente de todas elas, que estão descritas em detalhes a seguir.

Durante o desenvolvimento do processo de capacitação foram realizadas reuniões e visitas de diagnóstico junto a cada montadora que serviram para definição de escopo dos serviços contratados e formulação de proposta técnico-comercial. A partir destas informações iniciais ocorreu o mapeamento de competências e objetivos de aprendizado, o desenvolvimento de materiais dos participantes e do instrutor, a escolha de abordagem de aprendizagem, culminando com a aprovação final pelo cliente do projeto de capacitação. 
Durante a implantação do processo de capacitação foram realizadas as atividades de planejamento de turmas de treinamento, entrevistas iniciais com participantes visando esclarecer os projetos práticos a serem usados para obtenção da certificação, desenvolvimento de demais consultores para atuar como instrutores de treinamento e realização de treinamentos.

Durante o acompanhamento do processo de capacitação foram realizadas as atividades de análise de resultados e percepções de cada turma de treinamento, aprimoramento de material ou atividades de treinamento, realimentação aos instrutores sobre pontos fortes e áreas que requerem melhorias no seu desempenho, acompanhamento de projetos práticos dos agentes internos seguido de realimentação sobre pontos fortes e oportunidades de melhoria, reuniões com gestores, coordenadores e outras partes interessadas no processo de capacitação.

Em suma, o papel desempenhado pela consultoria nestes casos foi análogo ao de um catalisador que estimula e facilita a transformação dos profissionais em agentes internos de melhoria contínua, sem, contudo, realizar as atividades de melhoria em si.

\subsection{Descrição das intervenções de capacitação entre 2012 e 2014}

As intervenções de capacitação entre os anos de 2012 a 2014 serão descritas considerando os seguintes aspectos: propósito ou necessidade de cada montadora ao adotar um programa de melhoria contínua, estrutura organizacional de apoio à melhoria contínua, método e critérios de seleção das pessoas escolhidas para participar do processo de capacitação, incluindo o método e critérios de escolha de projetos de melhoria iniciais, competências requeridas no processo de capacitação e abordagem de aprendizagem utilizada no desenvolvimento destas competências, método e critérios de acompanhamento e avaliação da eficácia de projetos.

Para preservar a identidade das empresas estudadas elas serão chamadas neste estudo de Montadora A, Montadora B e Montadora C. As montadoras A e C são plantas diferentes do mesmo grupo automobilístico. A montadora B é parte de outro grupo automobilístico. Isto possibilita a comparação dos resultados entre grupos automobilísticos e entre plantas produtivas diferentes dentro do mesmo grupo. Nas três montadoras ocorreu uma decisão 
formal de promoção do programa de melhoria contínua e a contratação do presente pesquisador como consultor externo e coordenador do processo de capacitação.

\subsubsection{Propósito da adoção do programa de melhoria contínua}

Nas três montadoras, ocorreu uma motivação comum relativa à decisão de implantar modelos de excelência em operações utilizando projetos de melhoria. $\mathrm{O}$ fator motivador principal não ocorreu a partir da busca de soluções após um diagnóstico das estratégias organizacionais e de operações e sim da adoção e adaptação das melhores práticas gerenciais de suas matrizes estrangeiras (Netland \& Aspelund, 2014).

Podem-se sumarizar cinco etapas do programa de melhoria contínua nestas montadoras: desenvolvimento e aprimoramento contínuo do modelo de excelência em operações da matriz estrangeira, exportação seguida de adoção do modelo nas filiais brasileiras, escolha, capacitação e apoio aos agentes internos de melhoria, realização de projetos de melhoria pelos agentes internos e finalmente, obtenção de melhoria no desempenho de operações, conforme diagrama de etapas de institucionalização apresentadas na Ilustração 2. A atuação da consultoria externa deu-se principalmente nas etapas 3 e 4 deste diagrama, logo após a filial brasileira da montadora decidiu adotar o modelo de excelência corporativo em sua operação.

Ilustração 2 - Institucionalização da melhoria contínua.

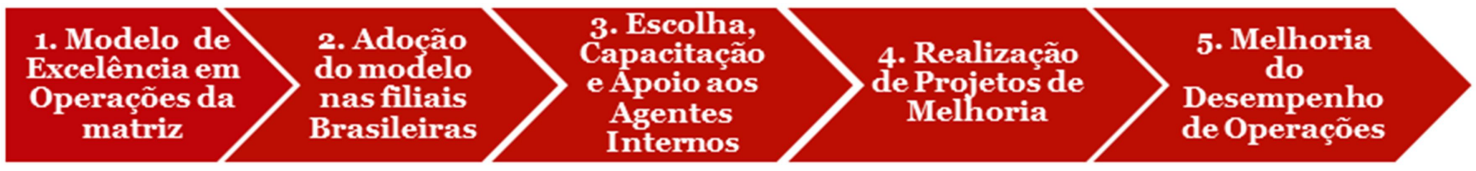

Fonte: elaborado pelo autor.

$\mathrm{Na}$ montadora A e C a capacitação dos agentes internos de melhoria contínua foi parte da implantação de um modelo de excelência baseado no programa seis sigma. Já na montadora B o modelo de excelência que requer a melhoria contínua é o WCM, acrônimo do termo em inglês World Class Manufacturing, ou seja, manufatura classe mundial. 


\subsubsection{Estrutura organizacional de apoio à melhoria contínua}

As montadoras $\mathrm{A}$ e $\mathrm{C}$ tem em comum a seguinte estrutura organizacional de apoio à melhoria contínua: um coordenador de melhoria contínua local, agentes internos de melhoria contínua e seus gestores. O coordenador de melhoria contínua é um profissional com dedicação exclusiva para apoiar os agentes internos com seus projetos e planejar atividades de treinamento e acompanhamento. $\mathrm{O}$ agente interno de melhoria é o profissional que é escolhido para ser capacitado e passar a realizar projetos de melhoria. Os gestores dos agentes internos representam a chefia imediata dos mesmos, usualmente denominados padrinhos. Uma diferença significativa na estrutura de apoio ao programa é que na Montadora A o papel de patrocinador do programa foi desempenhado pelo diretor da qualidade e na Montadora $\mathrm{C}$ o patrocinador foi o diretor de planta, o maior nível hierárquico local.

A estrutura organizacional de apoio à melhoria contínua na Montadora B é composta por coordenador de melhoria, analista e gerente de recursos humanos, agentes internos de melhoria e seus gestores. O patrocinador do programa foi o diretor de produção da planta.

\subsubsection{Seleção dos agentes internos de melhoria}

O método e critérios de seleção das pessoas escolhidas para participar do processo de capacitação foram distintos em cada uma das três montadoras estudadas.

Na montadora A, o programa de capacitação abrangeu a formação de 103 profissionais, 94 deles na função de analistas e engenheiros de garantia da qualidade. Anualmente o coordenador do programa seis sigma apresentava ao diretor da qualidade um plano de investimento em treinamento e acompanhamento de projetos em conjunto com um relatório de viabilidade. As vagas de treinamento aprovadas eram comunicadas as diversas áreas industriais. A contrapartida exigida era que os participantes deveriam escolher e conduzir pelo menos um projeto de melhoria que tivesse impacto de melhoria no mínimo de $30 \%$ sobre algum indicador de desempenho da empresa. Ao receber as solicitações de inscrição, o coordenador formava turmas de treinamento e comunicava o consultor externo quando as datas estavam confirmadas. Antes da realização do treinamento, cada agente interno e seu gestor era convidado para uma entrevista com o consultor externo com o objetivo de 
apresentar o projeto de melhoria inicial e receber a aprovação quanto a sua viabilidade. Todos os participantes selecionados continuaram desempenhando suas atividades de rotina após o treinamento e durante a fase de condução de projeto de melhoria.

Na montadora B, o programa de capacitação abrangeu a formação de 200 profissionais, todos eles na função do primeiro nível de liderança dos operários no departamento de produção. Diferentemente das montadoras A e C, a capacitação foi coordenada pelo departamento de recursos humanos e parte de uma estratégia de desenvolver novos líderes de produção, sendo 75 pessoas recém-contratadas através do programa de trainee e o restante composto de operadores experientes que estavam sendo promovidos à função de líder de produção. Cada participante deveria escolher, conduzir e concluir, durante o período de treinamento, dois projetos de melhoria com impacto na sua própria área produtiva. Após selecionados para o programa de capacitação, os participantes da montadora B foram submersos num regime de dedicação em tempo integral nas atividades de treinamento e condução dos projetos, não desempenhando nenhuma outra tarefa ligada a sua área de trabalho.

Na montadora C, o programa de capacitação abrangeu a formação de 107 profissionais, todos eles no nível de supervisão e/ou gestão de unidades fabris. Como na Montadora A, a verba para realização da capacitação também veio através do coordenador do programa seis sigma, entretanto o diretor de planta direcionou as vagas para todos os gerentes e supervisores de produção. Cada participante deveria escolher e conduzir pelo menos um projeto de melhoria que tivesse impacto de melhoria no mínimo de 30\% sobre algum indicador de desempenho ligado a sua área produtiva. A formação das turmas, incluindo entrevistas iniciais para avaliação de viabilidade dos projetos, foi realizada da mesma forma que na Montadora A. Assim como na Montadora A, todos os participantes selecionados continuaram desempenhando suas atividades de rotina após o treinamento e durante a fase de condução de projeto de melhoria.

\subsubsection{Competências requeridas e abordagem de aprendizagem}

Nas montadoras A e C, as competências requeridas no processo de capacitação dos agentes internos de melhoria foram idênticas, seguindo o mesmo padrão do programa seis sigma do grupo automobilístico. Após a escolha dos projetos, um treinamento de 24 horas, durante 3 
dias consecutivos, fundamentado na metodologia DMAIC, acrônimo com as iniciais das etapas de solução de problemas definir, medir, analisar, melhorar e controlar, foi provido a todos os profissionais inscritos. Adicionalmente, as seguintes ferramentas básicas de solução de problema foram abordadas: descrição de fenômeno através do 5W2H, Pareto, diagrama de causa-efeito, 5 porquês e validação de causa raiz, gráfico sequencial, plano de ação $5 \mathrm{~W} 2 \mathrm{H}$, avaliação de eficácia e padronização. Não foi abordado nenhum tipo de desenvolvimento de competências comportamentais ligadas a condução de projetos, nem aplicado exame final de conhecimento ao término do treinamento.

$\mathrm{Na}$ Montadora B, além da metodologia PDCA e das ferramentas básicas de solução de problema também endereçadas no treinamento das montadoras A e C, as competências requeridas para o agente interno incluiu diversas ferramentas e métodos ligados a cada um dos pilares do WCM: qualidade, desdobramento de custos, organização do posto de trabalho, logística, manutenção autônoma, manutenção profissional e preventiva, desenvolvimento de pessoas, segurança e meio ambiente. Para um escopo tão amplo foi realizado um treinamento de 176 horas, em 22 dias distribuídos durante 6 semanas. Adicionalmente, foram realizados treinamentos de desenvolvimento de competências comportamentais ligadas a liderança, comunicação, delegação, trabalho em equipe e administração do tempo. No último dia do treinamento foi aplicado um exame prático do tipo estudo de caso relativo a um projeto de melhoria.

A abordagem de aprendizagem do processo de capacitação foi escolhida em conjunto entre a consultoria e as três montadoras. Turmas de até 25 participantes foram divididas em equipes de 4 a 5 integrantes, com $50 \%$ do tempo dedicado a resolução de casos práticos, 30\% dedicado a leitura e discussão de exercícios conceituais e $20 \%$ do tempo em apresentação realizada pelo instrutor de treinamento. Após o treinamento, cada participante teve de concluir com sucesso um projeto de melhoria para obter a certificação de agente interno de melhoria.

Embora a terminologia usada pelas montadoras seja diferente, PDCA no caso da Montadora B, e DMAIC nas Montadoras A e C, a metodologia de realização de projetos de melhoria adotava o elemento central em comum: a responsabilidade de condução do projeto era do profissional treinado pela consultoria e não da equipe de projeto como um todo, pois tratou-se 
de um programa de capacitação individual nas três montadoras, o que torna válida a consideração da transformação dos profissionais nas três empresas num mesmo estudo.

\subsubsection{Acompanhamento de projetos de melhoria}

Nas montadoras A e C, após o treinamento, cada participante deveria formar uma equipe e conduzir um projeto de melhoria. Cada agente interno de melhoria, em conjunto com o seu gestor, deveria participar de seis encontros individuais de 50 minutos de duração a cada 20 dias, com o consultor externo. O objetivo era de apresentar situação atualizada do projeto e obter realimentação sobre pontos fortes e oportunidades de melhoria. A avaliação dos projetos foi contínua, ou seja, a cada encontro com o consultor a etapa correspondente do DMAIC deveria estar concluída com sucesso, conforme descrito no Quadro 1. No sexto encontro, o projeto deveria estar concluído, ou seja, a meta deveria ter sido alcançada, incluindo medidas de padronização para sustentar as ações de melhoria.

Quadro 1 - Acompanhamento contínuo de projetos nas montadoras A e C

\begin{tabular}{|l|l|l|}
\hline Encontro & Fase DMAIC & Critérios de avaliação de cada etapa de projeto \\
\hline $1^{\text {o }}$ & D- Definir & Escopo, meta e custo-benefício do projeto definidos. \\
\hline $2^{\mathbf{o}}$ & M- Medir & Estratificação do problema em fenômenos específicos. \\
\hline $3^{\text {o }}$ & A- Analisar & Causas potenciais identificadas. \\
\hline $4^{\text {o }}$ & A- Analisar & Causa raiz validada. \\
\hline $5^{\text {o }}$ & M- Melhorar & Plano de ação elaborado. \\
\hline $6^{\text {o }}$ & C- Controlar & Avaliação da eficácia da ação e padronização. \\
\hline
\end{tabular}

Fonte: elaborado pelo autor.

$\mathrm{Na}$ montadora $\mathrm{B}$, durante o treinamento, cada participante deveria formar uma equipe e conduzir dois projetos de melhoria: o primeiro denominado Kaizen Rápido, projeto realizado em 1 semana e geralmente ligado a restauração de padrões e melhoria de postos de trabalho produtivos, e o segundo denominado PDCA Kaizen, projeto realizado também durante as 6 semanas de treinamento e com impacto de melhoria significativo sobre algum indicador de desempenho da sua área produtiva. 


\subsubsection{Confirmação da problemática de pesquisa}

Ao conduzir outros projetos de consultoria e treinamento com as montadoras A, B e C durante os anos de 2014 e 2015, o presente pesquisador observou que, embora existisse uma política e estrutura organizacional para a excelência organizacional com a melhoria contínua sendo um dos pilares fundamentais, boa parte dos agentes internos de melhoria não iniciava novos projetos de forma voluntária. Recorrência e intencionalidade são aspectos essenciais da definição de melhoria contínua, e não foram integralmente observados.

Esta pesquisa visa avaliar, de forma mais objetiva ao ir além da simples percepção do consultor, a existência e tamanho desta lacuna na transformação de profissionais, membros da organização, em agentes internos de melhoria contínua, e, posteriormente, identificar elementos para resolvê-la. 


\section{REFERENCIAL TEÓRICO}

Inicialmente buscou-se identificar elementos já apontados na literatura acadêmica como relevantes em relação a questão de pesquisa sobre transformação efetiva de profissionais em agentes internos de melhoria contínua. Foi realizada uma busca com o termo continuous improvement no título de artigos acadêmicos de jornais nas bases de dados eletrônicos Proquest e Web of Science. Os filtros utilizados na pesquisa estão descritos no Quadro 2. Evitou-se, neste primeiro momento, a limitação de revisão de artigos relacionados a indústria automobilística, para obter acesso a um conjunto mais abrangente possível de artigos a serem analisados. A estratégia de considerar apenas artigos acadêmicos com o termo melhoria contínua no título foi adotada partindo da premissa de que a sua inclusão no título indica que a mesma está diretamente ligada a temática central de pesquisa de seus autores.

Quadro 2 - Filtros utilizados na pesquisa de publicações sobre melhoria contínua

\begin{tabular}{|l|l|}
\hline Tipo de informação & Filtro de pesquisa utilizado \\
\hline Domínio da pesquisa & Ciências sociais. \\
\hline Tipo de publicação & Artigo acadêmico. \\
\hline Área de pesquisa & Administração, Operações, Engenharia ou Economia. \\
\hline Título do documento & Constar o termo "melhoria contínua”. \\
\hline Data de publicação & De janeiro de 2006 até março de 2016. \\
\hline
\end{tabular}

Fonte: elaborado pelo autor.

A pesquisa resultou em 210 artigos da base Proquest e 61 artigos da base Web of Science. Foi feita a leitura do resumo de todos os 271 artigos, frutos da pesquisa inicial. Uma análise de relevância, objetivando uma revisão detalhada dos artigos que tinham uma relação direta com a questão de pesquisa, foi conduzida. O critério de seleção incluiu: artigos contendo algum tipo de revisão bibliográfica sobre melhoria contínua, artigos descrevendo barreiras ou fatores críticos de sucesso para melhoria contínua ou artigos relacionados ao desenvolvimento ou engajamento de agentes internos de melhoria.

O Quadro 3 apresenta os dezoito artigos foram identificados como relevantes ao tema da pesquisa, quatro oriundos de pesquisas realizadas em indústrias brasileiras, todos eles publicados em jornais com alto conceito no meio acadêmico. 
Quadro 3 - Referencial teórico do presente estudo

\begin{tabular}{|c|c|c|}
\hline Autores & Origem & Título da publicação \\
\hline Sanchez e Blanco (2014) & Internacional & $\begin{array}{l}\text { Total Quality Management \& } \\
\text { Business Excellence }\end{array}$ \\
\hline McLean e Antony (2014) & Internacional & $\begin{array}{l}\text { International Journal of Productivity } \\
\text { and Performance Management }\end{array}$ \\
\hline Oprime, Mendes, e Pimenta (2012) & Brasil & $\begin{array}{l}\text { International Journal of Productivity } \\
\text { and Performance Management }\end{array}$ \\
\hline Torres e Gatti (2011) & Brasil & $\begin{array}{l}\text { Journal of Technology Management } \\
\text { \& Innovation }\end{array}$ \\
\hline $\begin{array}{l}\text { García-Sabater, Marín-García e } \\
\text { Perelló-Marín (2012) }\end{array}$ & Internacional & $\begin{array}{l}\text { Human Factors and Ergonomics in } \\
\text { Manufacturing \& Service Industries }\end{array}$ \\
\hline Gonzalez e Martins (2015) & Brasil & Gestão \& Produção \\
\hline Hyland, Mellor e Sloan (2007) & Internacional & $\begin{array}{l}\text { International Journal of Technology } \\
\text { Management }\end{array}$ \\
\hline Lam, O’Donnell e Robertson (2015) & Internacional & $\begin{array}{l}\text { International Journal of Operations \& } \\
\text { Production Management }\end{array}$ \\
\hline Kornfeld e Kara (2011) & Internacional & $\begin{array}{l}\text { International Journal of Operations } \\
\text { and Production Management }\end{array}$ \\
\hline Salah (2015) & Internacional & $\begin{array}{l}\text { International Journal of Project } \\
\text { Organisation and Management }\end{array}$ \\
\hline Glover, Farris e Van Aken (2015) & Internacional & $\begin{array}{l}\text { International Journal of Production } \\
\text { Research }\end{array}$ \\
\hline Fryer, Ogden e Anthony (2013) & Internacional & $\begin{array}{l}\text { International Journal of Public Sector } \\
\text { Management }\end{array}$ \\
\hline Bessant, Caffyn e Gallagher (2001) & Internacional & Technovation \\
\hline Wu e Chen (2006) & Internacional & Technovation \\
\hline Yen-Tsang, Csillag e Siegler (2012) & Brasil & $\begin{array}{l}\text { RAE - Revista de Administração de } \\
\text { Empresas }\end{array}$ \\
\hline Aloini, Martini e Pellegrini (2011) & Internacional & $\begin{array}{l}\text { International Journal of Technology } \\
\text { Management }\end{array}$ \\
\hline Wenbin e Hongyi (2009) & Internacional & Total Quality Management \\
\hline
\end{tabular}




\begin{tabular}{|l|l|l|}
\hline & & Business Excellence \\
\hline Huang, Rode e Schroeder (2011) & Internacional & $\begin{array}{l}\text { Journal of International Business } \\
\text { Studies }\end{array}$ \\
\hline
\end{tabular}

Fonte: elaborado pelo autor.

Merece destaque inicial o recente artigo de Sanchez e Blanco (2014), contendo a abrangente revisão bibliográfica de mais de 1000 artigos relacionados ao tema de melhoria contínua, publicados entre 1980 e 2011 na base Web of Science. Reforça-se, nesta revisão, a importância de estudar melhoria contínua a partir dos dois eixos conceituais propostos no presente estudo. A institucionalização da melhoria contínua está presente em artigos com enfoque em fatores técnicos e organizacionais. A agência humana aparece nos artigos com enfoque social e individual. No Quadro 4 estão descritos os enfoques mais frequentes das pesquisas sobre melhoria contínua, segundo Sanchez e Blanco (2014), bem como sua relação com os dois eixos conceituais propostos neste estudo.

Quadro 4 - Enfoques de pesquisas sobre melhoria contínua

\begin{tabular}{|c|c|}
\hline $\begin{array}{l}\text { Enfoques mais frequentes das pesquisas sobre melhoria } \\
\text { contínua, segundo Sanchez e Blanco (2014) }\end{array}$ & $\begin{array}{l}\text { Relação com os eixos conceituais } \\
\text { deste estudo }\end{array}$ \\
\hline $1^{\circ}$ - Implantação da melhoria contínua & $\begin{array}{l}\text { Institucionalização e agência } \\
\text { humana }\end{array}$ \\
\hline $2^{\circ}$ - Ferramentas de melhoria contínua & Institucionalização \\
\hline $\begin{array}{l}3^{\circ} \text { - Relação da melhoria com outros sistemas de gestão } \\
\text { ou programas }\end{array}$ & $\begin{array}{l}\text { Institucionalização e agência } \\
\text { humana }\end{array}$ \\
\hline $4^{\circ}$ - Conceituação da melhoria contínua & Institucionalização \\
\hline $\begin{array}{l}5^{\circ} \text { - Práticas bem-sucedidas de recursos humanos na } \\
\text { melhoria contínua, indicadores e controles da melhoria } \\
\text { contínua }\end{array}$ & Agência humana \\
\hline $6^{\circ}$ - Cultura organizacional e melhoria contínua & Agência humana \\
\hline $\begin{array}{l}7^{0} \text { - Fatores críticos de sucesso e obstáculos a melhoria } \\
\text { contínua }\end{array}$ & $\begin{array}{l}\text { Institucionalização e agência } \\
\text { humana }\end{array}$ \\
\hline $8^{\circ}$ - Relação da melhoria contínua com a in & Institucionalização \\
\hline
\end{tabular}

Fonte: elaborado pelo autor. 
Os demais artigos acadêmicos do referencial teórico que foram considerados relevantes para o tema desta pesquisa foram agrupados nas categorias: obstáculos à melhoria contínua, fatores críticos de sucesso para melhoria contínua, comprometimento com a melhoria contínua, seleção e gerenciamento de projetos de melhoria contínua, sustentação dos resultados alcançados com a melhoria contínua, modelo de maturidades para melhoria contínua e melhoria contínua como uma capacidade organizacional estratégica. Uma sumarização dos achados dos artigos de cada uma destas categorias será apresentada a seguir, incluindo sua relação com a temática deste estudo; transformação efetiva de profissionais, membros da organização, em agentes internos de melhoria.

A relação do referencial com a temática será feita através da elaboração de assertivas dentro do contexto deste estudo. As assertivas serão agrupadas na seção 4 e formarão as proposições teóricas a serem confirmadas na pesquisa de campo. Estas assertivas ou afirmações serão, portanto, a matéria-prima bruta usadas para a formulação das proposições teóricas, que terão a função de dirigir a atenção para algo que deve ser examinado dentro do escopo da pesquisa (Yin, 2010), tornando-se parte essencial do protocolo de pesquisa, que será descrito detalhadamente na seção 4 deste trabalho.

\subsection{Obstáculos à melhoria contínua}

Em outra extensa revisão bibliográfica, feita por McLean e Antony (2014), foram apontados 8 temas relacionados a causas de fracasso das iniciativas de melhoria contínua. $\mathrm{O}$ tema 1 , motivação e expectativas, refere-se à motivação inadequada para a iniciativa como mimetismo em relação a outras empresas ou pressões externas e expectativa de resultado irrealista. $\mathrm{O}$ tema 2, cultura organizacional e ambiente, indica que algumas empresas possuem uma cultura organizacional ou operam em ambientes que restringem esforços de mudança. $\mathrm{O}$ tema 3, gerenciamento e liderança, está ligado a real falta de suporte gerencial, já que os projetos de melhoria demandam altos níveis de envolvimento e de alocação de tempo dos agentes internos. O tema 4, abordagem de implantação, estabelece que o nível em que a iniciativa é implementada, a velocidade de desdobramento da iniciativa pela empresa e o método de implementação são aspectos fundamentais, ressaltando a importância da integração de ferramentas e técnicas com os processos organizacionais existentes e a escolha cuidadosa da pessoa ou equipe de coordenação da iniciativa. O tema 5 , treinamento, aponta para a 
importância do conteúdo, abordagem de aprendizagem e aplicação prática dos conhecimentos aprendidos durante a capacitação dos agentes internos. O tema 6 , gestão de projeto, identifica a seleção inadequada do projeto, escopo grande ou pequeno demais ou existência de soluções pré-determinadas, participação ativa da equipe de projeto e suporte de mentores aos agentes internos de melhoria. O tema 7, nível de envolvimento do agente interno de melhoria, relata a importância da apropriada alocação de tempo e de delegação, tratativa de conflito e acúmulo de papéis, e, o aspecto individualizado das reservas dos próprios agentes quanto a iniciativa de melhoria, fruto de experiências prévias dos agentes com outros programas de mudança e preocupações relacionadas com a segurança de permanência no trabalho. O tema 8, realimentação e resultados, descreve a falha dos mecanismos de análise crítica de projetos que pode ser mal realizada ou mal comunicada dentro da organização e a falha de apuração dos resultados que pode gerar a percepção de fracasso da iniciativa no longo prazo.

Três estágios progressivos para endereçar estes oito temas de fracasso das iniciativas de melhoria contínua são demonstrados na Ilustração 3. Os três estágios estão congruentes com o relato das intervenções realizadas: atividades de preparação antes da realização da capacitação dos profissionais, atividades de capacitação em si e finalmente, atividades de acompanhamento de projetos como a etapa final de certificação dos agentes internos de melhoria.

Ilustração 3 - Modelo de 3 estágios de McLean e Antony.

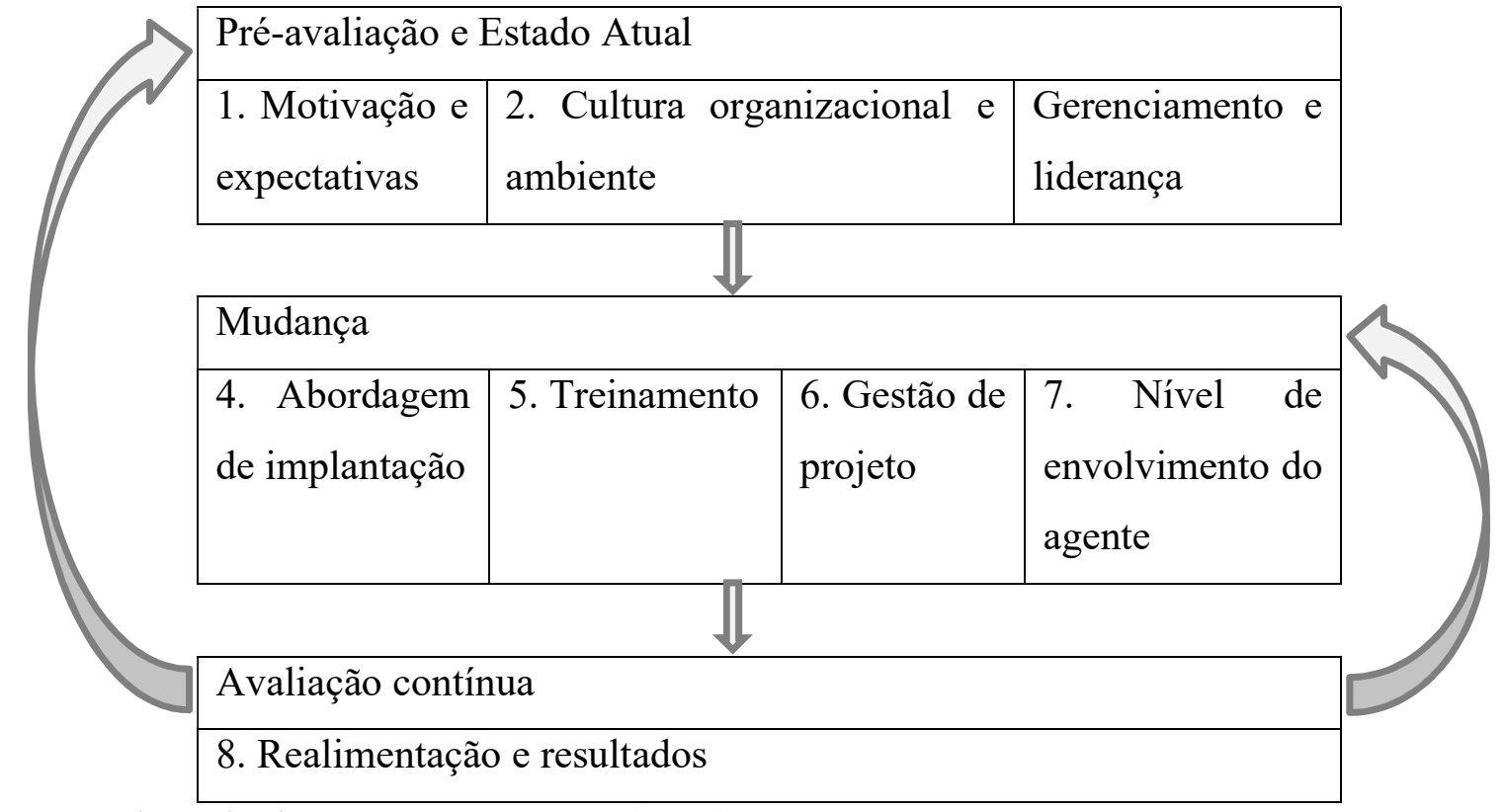

Fonte: Adaptado de McLean e Antony (2014) 
Um estudo realizado com 46 indústrias brasileiras identificou três situações como maiores dificuldades na condução de atividade de melhoria contínua: difundir os esforços de melhoria de forma a aumentar o grau de participação dos colaboradores melhoria contínua, dar início ao programa de melhoria e gerenciar vários projetos simultaneamente (Oprime, Mendes, \& Pimenta, 2012). A pesquisa ainda apontou os seguintes fatores críticos de sucesso ligados a implantação da melhoria contínua: treinamento de pessoal em metodologia de solução de problemas integrada com o uso de ferramentas fundamentais e avançadas da qualidade, existência de planos de sugestão visando a participação dos colaboradores na melhoria do processo produtivo, comunicação face-a-face e visitas regulares dos gestores na fábrica para acompanhar as rotinas de trabalho, e a existência de um sistema de incentivos, não necessariamente financeiro.

Na pesquisa de Torres e Gatti (2011) são apontados os seguintes fatores para superação dos obstáculos a institucionalização da melhoria contínua: liderança, comunicação, estrutura, capacitação e monitoramento do desempenho. $O$ fator liderança indica que o papel fundamental do líder é a mobilização e alinhamento de esforços das equipes de trabalho em torno das metas organizacionais quantitativas. Por comunicação entende-se a aplicação de programas de comunicação em todos os níveis, com linguagem e frequência apropriadas. Outro fator relevante é a estrutura para formação de equipes de melhoria com patrocinadores de projetos e comitê de coordenação do programa, incluindo reuniões regulares entre os agentes de melhoria, operários e líderes. Capacitação é representada pela a provisão de treinamentos técnicos e comportamentais no local de trabalho e para as equipes de melhoria. Com o monitoramento do desempenho espera-se o acompanhamento dos resultados das atividades e dos projetos de melhoria a partir dos novos padrões de trabalho. Por fim, o fator tecnologia requer que equipamentos devam ser adequados às necessidades do negócio, sendo sua estabilidade essencial para a sustentação dos novos padrões de trabalho.

Do referencial teórico ligado a obstáculos à melhoria continua, podemos estabelecer as assertivas listadas no Quadro 5, a serem verificadas na pesquisa de campo. 
Quadro 5 - Assertivas identificadas a partir do referencial teórico sobre obstáculos a melhoria contínua.

\begin{tabular}{|c|c|}
\hline Item & Assertivas a partir do referencial teórico de obstáculos a melhoria \\
\hline AS1 & $\begin{array}{l}\text { É necessário uma motivação e crença genuína, por parte dos gestores e alta direção, } \\
\text { de que a transformação dos profissionais em agentes internos é relevante para a } \\
\text { melhoria do desempenho organizacional. }\end{array}$ \\
\hline AS2 & $\begin{array}{l}\text { É necessário um suporte gerencial a realização de projetos de melhoria, o que } \\
\text { implica em altos níveis de envolvimento alocação de tempo do gestor para liderar a } \\
\text { mudança. Exemplo disso é a comunicação face-a-face e visitas regulares dos } \\
\text { gestores na fábrica para acompanhar as rotinas de trabalho. }\end{array}$ \\
\hline AS3 & $\begin{array}{l}\text { É necessário considerar o nível organizacional em que estão situados a primeira } \\
\text { leva de profissionais a serem capacitados e o tipo e velocidade de desdobramento } \\
\text { para os demais níveis organizacionais, aumentando o grau de participação dos } \\
\text { membros da organização. }\end{array}$ \\
\hline AS4 & $\begin{array}{l}\text { É necessário o comprometimento gerencial não apenas com a capacitação, mas } \\
\text { também com o método de implantação. }\end{array}$ \\
\hline AS5 & $\begin{array}{l}\text { É necessário prever e prover a integração das metodologias de solução de } \\
\text { problemas e ferramentas fundamentais e avançadas da qualidade, ensinadas aos } \\
\text { agentes, com os processos organizacionais existentes. }\end{array}$ \\
\hline AS6 & $\begin{array}{l}\text { É necessário a escolha cuidadosa das pessoas com função de coordenação da } \\
\text { iniciativa de melhoria contínua. }\end{array}$ \\
\hline AS7 & $\begin{array}{l}\text { É necessário a escolha adequada de abordagem de aprendizagem e aplicação } \\
\text { prática dos conteúdos, que devem ser técnicos e comportamentais, trabalhados } \\
\text { durante o treinamento dos agentes internos. }\end{array}$ \\
\hline AS8 & $\begin{array}{l}\text { É necessária a seleção adequada de projetos, com objetivos mensuráveis alinhados } \\
\text { com a estratégia organizacional. }\end{array}$ \\
\hline AS9 & $\begin{array}{l}\text { É necessário que os projetos de melhoria conduzidos pelos agentes internos contem } \\
\text { com a participação ativa da equipe de projeto e suporte de mentores aos agentes } \\
\text { internos. }\end{array}$ \\
\hline AS10 & $\begin{array}{l}\text { É necessário a resolução de conflito e acúmulo de papéis dos agentes internos, o } \\
\text { que significa que os agentes internos devem ter desenvolvidas as habilidades de } \\
\text { gerenciamento de conflitos, gerenciamento de tempo e delegação. }\end{array}$ \\
\hline
\end{tabular}




\begin{tabular}{|l|l|}
\hline AS11 & $\begin{array}{l}\text { É necessário assegurar uma apuração consistente dos resultados dos projetos de } \\
\text { melhoria, incluindo a verificação do estabelecimento eficaz de novos padrões de } \\
\text { trabalho. }\end{array}$ \\
\hline AS12 & $\begin{array}{l}\text { É necessário assegurar uma comunicação efetiva dos resultados dos projetos dentro } \\
\text { da organização. Para ser efetiva a comunicação deve ser realizada em todos os } \\
\text { níveis, com linguagem e frequência apropriadas. }\end{array}$ \\
\hline AS13 & $\begin{array}{l}\text { É necessário monitorar a percepção sobre a eficácia dos projetos de melhoria, de } \\
\text { forma a prevenir e corrigir percepções de fracasso da transformação dos agentes } \\
\text { internos. }\end{array}$ \\
\hline AS14 & $\begin{array}{l}\text { É necessário estabelecer mecanismos de coordenação de projetos de melhoria que } \\
\text { ocorrem concomitantemente, em especial, quanto ao alinhamento de objetivos e ao } \\
\text { uso de recursos comuns e escassos. }\end{array}$ \\
\hline AS15 & $\begin{array}{l}\text { É necessário a existência de planos de sugestão visando a participação dos } \\
\text { colaboradores na melhoria do processo produtivo. }\end{array}$ \\
\hline AS16 & $\begin{array}{l}\text { É necessário a existência de um sistema de incentivos, não necessariamente } \\
\text { financeiro, para que os profissionais tornem-se motivados com a sua transformação } \\
\text { em agentes internos de melhoria. }\end{array}$ \\
É necessário a realização de reuniões regulares entre os agentes de melhoria, \\
operios e líderes.
\end{tabular}

Fonte: elaborado pelo autor.

\subsection{Fatores críticos de sucesso da melhoria contínua}

Ao realizar extensa pesquisa bibliográfica e entrevistar funcionários de 14 plantas de autopeças espanholas com experiência de 7 a 9 anos na implantação de atividades de melhoria contínua, García-Sabater, Marín-García e Perelló-Marín (2012) relatam as seguintes ações facilitadoras do desenvolvimento de atividades de melhoria contínua:

- Envolvimento gerencial: o aspecto mais citado na pesquisa, sendo considerado o mais importante e indispensável pelos entrevistados.

- Alinhamento estratégico: identificar problemas que estão acima do apagar incêndios do diaa-dia e que representam melhorias em atividades significativas para o negócio. 
- Objetivos mensuráveis: baseados em medições confiáveis e acordados com a liderança.

- Gestor-Líder de Melhoria: este elemento é diferente do envolvimento gerencial porque é realizado por um profissional em tempo integral para realização, apoio e coordenação dos diversos projetos de melhoria.

- Envolvimento dos operários: buscar participação ativa dos operários em fornecer ideias e executar as melhorias propostas, com cuidado especial a comunicação clara para afastar o medo de perda de emprego em função das melhorias.

- Recursos: embora tipicamente de baixo custo, a atividade de melhoria contínua demanda como principal recurso o tempo de trabalho dedicado aos projetos e isto deve ser considerado na carga de trabalho dos agentes de melhoria.

- Criação de nova estrutura: times de trabalho multidisciplinares são importantes para atacar problemas que permeiam diversos departamentos funcionais, com seus líderes selecionados com base no seu conhecimento do processo envolvido e nas ferramentas necessárias para a solução do problema.

- Criação de uma metodologia própria: formatação de um manual de boas práticas e metodologias como modelo próprio de excelência em operações, geralmente denominado sistema de produção da empresa.

- Seleção de projetos de melhoria: importante o atingimento de sucesso reconhecido pela direção nos projetos iniciais, o que se consegue com a seleção de projetos alinhados com a solução de problemas significativos sob a ótica da direção.

- Aspectos culturais: ambientes de trabalho mais informais e menor senioridade dos colaboradores são fatores que diminuem as resistências as mudanças e, portanto, a execução de melhorias planejadas.

- Treinamento e Habilidades: desenvolvimento de habilidades para solução de problemas alinhada com práticas de gerenciamento adequadas é central para a sustentabilidade da melhoria contínua.

Gonzalez e Martins (2015) realizaram um recente estudo de múltiplos casos sobre competências habilitadoras da melhoria contínua em duas empresas do setor automobilístico e duas empresas do setor de bens de capital. Na revisão da literatura, foram mapeadas onze competências que sustentam a melhoria contínua: entendimento das metas organizacionais, sistema de gestão estruturado para melhoria contínua, apoio e envolvimento gerencial, envolvimento dos funcionários, melhoria desenvolvida em grupo, autonomia para a prática da 
melhoria, desenvolvimento de competências dos indivíduos, cultura voltada para melhoria contínua, aprendizagem, compartilhamento do conhecimento e interação interorganizacional. Dentre as conclusões da pesquisa estão os seguintes fatos que ocorrem na indústria automobilística: busca de maior envolvimento dos funcionários tanto de nível operacional quanto gerencial, ambientes organizacionais com interação e integração dos indivíduos alcançam maiores níveis de aprendizagem que, por sua vez, sustentam a prática da melhoria contínua, bem como o resgate e a utilização do conhecimento gerado pelos indivíduos.

Um outro estudo, realizado entre os anos de 2000 a 2003, investigando a percepção de gestores de 89 fábricas australianas constatou que o desempenho do negócio como um todo se beneficia substancialmente da aplicação de métodos de melhoria contínua (Hyland, Mellor, \& Sloan, 2007). A comunicação direta entre gestores e colaboradores e a aplicação de treinamentos em métodos e ferramentas de solução de problemas foram os dois aspectos considerados mais importantes para alcançar as melhorias de desempenho.

Do referencial teórico ligado a fatores críticos de sucesso para a melhoria contínua, podemos estabelecer as assertivas listadas no Quadro 6, a serem verificadas na pesquisa de campo. Ressalta-se que estão listados no Quadro 6 apenas as assertivas que não puderam ser inferidas dos referenciais teóricos analisados anteriormente. Desta forma, uma assertiva citando a necessidade do envolvimento gerencial, aspecto recorrente nos estudos sobre fatores críticos de sucesso, não está listada no Quadro 6, dado que já aparece como a assertiva AS2, previamente descrita no Quadro 5.

Quadro 6 - Proposições identificadas a partir do referencial teórico sobre fatores críticos de sucesso para a melhoria contínua.

\begin{tabular}{|l|l|}
\hline Item & Assertivas a partir do referencial teórico sobre fatores críticos de sucesso \\
\hline AS19 & $\begin{array}{l}\text { É necessário que o coordenador de melhoria seja um profissional em tempo } \\
\text { integral para realização, apoio e coordenação dos diversos projetos de melhoria. }\end{array}$ \\
\hline AS20 & $\begin{array}{l}\text { É necessário buscar participação ativa dos operários em fornecer ideias e executar } \\
\text { as melhorias propostas, com cuidado especial a comunicação clara para afastar o } \\
\text { medo de perda de emprego em função das melhorias. }\end{array}$ \\
\hline AS21 & $\begin{array}{l}\text { É necessário a seleção times de trabalho multidisciplinares em projetos de melhoria } \\
\text { que visam resolver problemas que permeiam diversos departamentos funcionais. }\end{array}$ \\
\hline
\end{tabular}




\begin{tabular}{|l|l|}
\hline AS22 & $\begin{array}{l}\text { É necessário identificar o nível de complexidade do projeto e prover o } \\
\text { conhecimento de ferramentas em função desta complexidade. }\end{array}$ \\
\hline AS23 & $\begin{array}{l}\text { É necessário a criação ou adaptação de conceitos em uma metodologia própria de } \\
\text { melhoria e modelo de excelência em operações. }\end{array}$ \\
\hline AS24 & $\begin{array}{l}\text { É necessário atingir sucesso com os projetos iniciais, solucionando problemas } \\
\text { significativos sob a ótica da direção, e, desta forma, gerando um ciclo virtuoso de } \\
\text { apoio gerencial a realização de novos projetos de melhoria. }\end{array}$ \\
\hline AS25 & $\begin{array}{l}\text { É necessário o estabelecimento de um ambiente de colaboração para com o agente } \\
\text { interno, para que as informações necessárias a realização do projeto de melhoria } \\
\text { possam fluir com maior rapidez e acuracidade. }\end{array}$ \\
\hline AS26 & $\begin{array}{l}\text { É necessário um processo de gestão do conhecimento efetivo, capaz de resgatar e } \\
\text { utilizar o conhecimento gerado em projetos anteriores. }\end{array}$ \\
\hline AS27 & $\begin{array}{l}\text { É necessário que o agente interno de melhoria entenda as metas organizacionais. } \\
\text { É necessário que o agente interno de melhoria possua autonomia para realizar as } \\
\text { atividades requeridas pelo projeto de melhoria. }\end{array}$ \\
\hline AS28
\end{tabular}

Fonte: elaborado pelo autor.

\subsection{Comprometimento com a melhoria contínua}

A pesquisa de Lam, O’Donnell e Robertson (2015) conclui que as seguintes ações e comportamentos gerenciais contribuem para o comprometimento dos colaboradores com as iniciativas de melhoria contínua: a colaboração entre os agentes internos de melhoria, o estabelecimento de um canal para questionamentos e consultas, apelos de inspiração, persuasão racional e até mesmo bajulação. $\mathrm{O}$ aumento da conscientização e uso de táticas de influência pelos gestores pode aumentar a taxa de sucesso dos projetos de melhoria e ainda melhorar o relacionamento com sua equipe.

Do referencial teórico ligado ao comprometimento com a melhoria contínua, podemos estabelecer as assertivas listadas no Quadro 7, a serem verificadas na pesquisa de campo. Ressalta-se que estão listados no Quadro 7 apenas as assertivas que não puderam ser inferidas dos referenciais teóricos analisados anteriormente. 
Quadro 7 - Assertivas identificadas a partir do referencial teórico sobre comprometimento com a melhoria contínua.

\begin{tabular}{|l|l|}
\hline Item & Assertivas a partir do referencial teórico sobre comprometimento com a melhoria \\
\hline AS29 & $\begin{array}{l}\text { É necessário que o estabelecimento de um ambiente de colaboração entre os } \\
\text { agentes internos de melhoria. }\end{array}$ \\
\hline AS30 & $\begin{array}{l}\text { É necessário o estabelecimento de um canal de comunicação com os agentes } \\
\text { internos de melhoria que responda a seus questionamentos e consultas. }\end{array}$ \\
\hline AS31 & $\begin{array}{l}\text { É necessário o uso de táticas de influência pelos gestores, incluindo apelos } \\
\text { racionais e de inspiração. }\end{array}$ \\
\hline
\end{tabular}

Fonte: elaborado pelo autor.

\subsection{Seleção e gerenciamento de projetos de melhoria contínua}

Kornfeld e Kara (2011) focaram em seu estudo bibliográfico a questão da importância da seleção adequada dos projetos na iniciativa melhoria contínua. As três principais lacunas identificadas foram a otimização do estado futuro, a geração de portfólio de projetos e a medição dos resultados. Segundo os autores, novos projetos deveriam ser selecionados no intuito de avançar continuamente na direção de melhoria de desempenho já alcançado pelo projeto anterior, o que é denominado otimização do estado futuro. As diversas oportunidades de melhoria deveriam ser agrupadas, priorizadas e selecionadas para assegurar integração e maior grau de impacto em áreas prioritárias oriundas da estratégia de operações, fator denominado geração de portfólio. Por medição de resultados, os autores apontam para a importância da escolha de métricas adequadas para julgamento dos resultados desde a fase de seleção de projetos de melhoria.

Ainda sobre a importância de adoção de critérios para seleção de projetos de melhoria, o estudo de Salah (2015) sugere a adoção de uma matriz de seleção e priorização de projetos com oito fatores a serem considerados: ganho financeiro que o projeto irá agregar, alinhamento com a estratégia e visão de futuro do negócio, impacto nos indicadores de desempenho do negócio, alinhamento com projetos prévios realizados, questão importante ou solução de problema percebido pelo cliente, risco potencial ao desempenho que requer ação preventiva e, finalmente, questão ligada ao negócio, como necessidade de expansão ou otimização de recurso chave. 
Do referencial teórico ligado a seleção e gerenciamento de projetos de melhoria contínua, podemos estabelecer as assertivas listadas no Quadro 8, a serem verificadas na pesquisa de campo. Ressalta-se que estão listados no Quadro 8 apenas as assertivas que não puderam ser inferidas dos referenciais teóricos analisados anteriormente.

Quadro 8 - Assertivas identificadas a partir do referencial teórico sobre seleção e gerenciamento de projetos de melhoria contínua.

\begin{tabular}{|c|c|}
\hline Item & $\begin{array}{l}\text { Assertivas a partir do referencial teórico sobre seleção e gerenciamento de projetos } \\
\text { de melhoria }\end{array}$ \\
\hline AS32 & $\begin{array}{l}\text { É necessário selecionar projetos que otimizem continuamente o estado futuro, ou } \\
\text { seja, parta das melhorias já alcançadas e promova a melhoria de desempenho, } \\
\text { como uma extensão das melhorias alcançadas. }\end{array}$ \\
\hline AS33 & $\begin{array}{l}\text { É necessário estabelecer um gerenciamento do portfólio de projetos, visando } \\
\text { integração e maior grau de impacto em áreas prioritárias oriundas da estratégia de } \\
\text { operações. }\end{array}$ \\
\hline AS34 & $\begin{array}{l}\text { É necessário estabelecer, desde a fase de seleção inicial de projetos, a escolha de } \\
\text { métricas adequadas para julgamento dos resultados a serem alcançados. }\end{array}$ \\
\hline AS35 & $\begin{array}{l}\text { É necessário realizar a seleção de projetos através de critérios objetivos, por } \\
\text { exemplo através do uso de uma matriz de seleção e priorização de projetos. }\end{array}$ \\
\hline
\end{tabular}

Fonte: elaborado pelo autor.

\subsection{Sustentação dos resultados alcançados com os projetos de melhoria contínua}

A questão da sustentação de resultados alcançados após a realização de um projeto de melhoria foi estudada por Glover, Farris e Van Aken (2015) ao acompanhar 65 projetos de melhoria realizados em oito fábricas distintas. Os seguintes fatores tiveram impacto significativo quanto à sustentação de resultados: aceitação a mudança, liderar o caminho e aprendizagem organizacional.

A aceitação a mudança significa colaboradores e gestores com tolerância a questionar e modificar procedimentos ou práticas enraizadas na busca de melhorias. A aceitação a mudança foi observada em níveis diferentes dentro da mesma organização, e fortemente 
presente em setores produtivos onde há o encorajamento de aprendizagem e tomar iniciativa. Gestores de áreas com alta aceitação de mudança preferem ouvir pedidos de desculpas ao invés de pedidos de permissão para tomar iniciativa. Liderar o caminho implica em realização, pelos gestores, de atividades de reforço da mudança, como conduzir pessoalmente e suportar campanhas ou eventos de melhoria, acompanhar a manutenção dos novos procedimentos, apoiar a aderência dos colaboradores de seguir os novos métodos de trabalho, reconhecer valores e fatores não econômicos. O aprendizado e a colaboração entre os trabalhadores da mesma área e um senso compartilhado de responsabilidade sobre as outras áreas também tiveram impacto positivo na sustentação de resultados dos projetos de melhoria. Para chegar a estas conclusões, este estudo considerou uma observação direta de todas as fábricas no período de 9 a 18 meses após a conclusão dos projetos de melhoria (Glover et al., 2015).

Do referencial teórico ligado a seleção e gerenciamento de projetos de melhoria contínua, podemos estabelecer as assertivas listadas no Quadro 9, a serem verificadas na pesquisa de campo. Ressalta-se que estão listados no Quadro 9 apenas as assertivas que não puderam ser inferidas dos referenciais teóricos analisados anteriormente.

Quadro 9 - Assertivas identificadas a partir do referencial teórico sobre sustentação dos resultados alcançados com os projetos de melhoria.

\begin{tabular}{|l|l|}
\hline Item & $\begin{array}{l}\text { Assertivas a partir do referencial teórico sobre sustentação dos resultados } \\
\text { alcançados com os projetos de melhoria }\end{array}$ \\
\hline AS36 & $\begin{array}{l}\text { É necessário a promoção da aceitação a mudança, ou seja, instigar nos agentes } \\
\text { internos e em seus gestores o questionamento e modificação de procedimentos ou } \\
\text { práticas enraizadas na busca de melhorias. }\end{array}$ \\
\hline AS37 & $\begin{array}{l}\text { É necessário a promoção de um senso compartilhado de responsabilidade e } \\
\text { contribuição para com outras áreas, não só as de atuação do agente interno. }\end{array}$ \\
\hline
\end{tabular}

Fonte: elaborado pelo autor.

\subsection{Modelo de maturidade para a melhoria contínua}

Fryer, Ogden e Anthony (2013) revisaram o modelo clássico e abrangente de condução da melhoria contínua oriundo de uma pesquisa ação realizada em 103 empresas (Bessant, 
Caffyn, \& Gallagher, 2001). Bessant et al. (2001) propuseram oito rotinas chaves para o sucesso da atividade de melhoria contínua, como descrito no Quadro 10. Fryer, Ogden e Anthony (2013) adicionaram ao modelo de Bessant et al. (2001) oito indicadores distribuídos em três níveis de maturidade da iniciativa de melhoria contínua, como descrito no Quadro 11.

Quadro 10 - Rotinas chaves da melhoria contínua segundo Bessant et al. (2001)

\begin{tabular}{|c|c|}
\hline Habilidade & Descrição \\
\hline $\begin{array}{l}\text { Compreender a } \\
\text { melhoria contínua }\end{array}$ & Articular os valores básicos da melhoria contínua. \\
\hline $\begin{array}{l}\text { Tornar a melhoria } \\
\text { contínua um hábito }\end{array}$ & Gerar envolvimento sustentável com a melhoria contínua. \\
\hline $\begin{array}{l}\text { Focar na melhoria } \\
\text { contínua }\end{array}$ & $\begin{array}{l}\text { Ligar as atividades de melhoria contínua com as metas estratégicas } \\
\text { da empresa. }\end{array}$ \\
\hline Liderar o caminho & $\begin{array}{l}\text { Liderar, dirigir e suportar a criação e sustentação de } \\
\text { comportamentos de melhoria contínua. }\end{array}$ \\
\hline $\begin{array}{l}\text { Alinhar a melhoria } \\
\text { contínua }\end{array}$ & $\begin{array}{l}\text { Criar consistência entre os valores e comportamentos de melhoria } \\
\text { contínua com o contexto organizacional. }\end{array}$ \\
\hline $\begin{array}{l}\text { Solucionar problemas } \\
\text { de forma compartilhada }\end{array}$ & $\begin{array}{l}\text { Mover as atividades de melhoria contínua através dos limites } \\
\text { departamentais e organizacionais. }\end{array}$ \\
\hline $\begin{array}{l}\text { Melhorar a melhoria } \\
\text { contínua }\end{array}$ & $\begin{array}{l}\text { Gerenciar de forma estratégica o desenvolvimento da melhoria } \\
\text { contínua. }\end{array}$ \\
\hline $\begin{array}{l}\text { Aprendizagem } \\
\text { organizacional }\end{array}$ & $\begin{array}{l}\text { Gerar a possibilidade de que o aprendizado ocorra e seja capturado } \\
\text { em todos os níveis organizacionais. }\end{array}$ \\
\hline
\end{tabular}

Fonte: Adaptado de Bessant et al. (2001)

Quadro 11 - Indicadores de maturidade da melhoria contínua segundo Fryer et al. (2013)

\begin{tabular}{|l|lr|l|l|}
\hline \multirow{2}{*}{ Indicador } & \multicolumn{4}{l|}{ Nível de maturidade da iniciativa de melhoria contínua } \\
\cline { 2 - 5 } & \multicolumn{2}{l|}{ Movendo-se } & Transformando & Integrando \\
\hline 1. Integração da & Nenhuma estrutura & Times identificam e & Melhoria continua \\
melhoria contínua & $\begin{array}{l}\text { formal para a } \\
\text { realização } \\
\text { melhoria. }\end{array}$ & de & realizam atividades & não é mais uma \\
& & & $\begin{array}{l}\text { atividade adicionada } \\
\text { a rotina, e sim uma }\end{array}$ \\
\hline
\end{tabular}




\begin{tabular}{|c|c|c|c|}
\hline & & & $\begin{array}{l}\text { parte integral do } \\
\text { trabalho de } \\
\text { indivíduos e equipes. }\end{array}$ \\
\hline $\begin{array}{l}\text { 2. Extensão dos } \\
\text { projetos de melhoria }\end{array}$ & $\begin{array}{ll}\text { Atividade } & \text { de } \\
\text { melhoria focada no } \\
\text { nível local. }\end{array}$ & $\begin{array}{l}\text { Atividade de } \\
\text { melhoria envolve } \\
\text { pessoas de diferentes } \\
\text { departamentos, } \\
\text { seções e divisões. }\end{array}$ & $\begin{array}{l}\text { Pessoas consideram } \\
\text { clientes externos e } \\
\text { internos ao conduzir } \\
\text { projetos de melhoria. }\end{array}$ \\
\hline 3. Suporte gerencial & $\begin{array}{l}\text { Esporadicamente } \\
\text { alguns gestores } \\
\text { promovem a } \\
\text { melhoria contínua. }\end{array}$ & $\begin{array}{l}\text { Existe sério esforço } \\
\text { organizacional para } \\
\text { adotar a melhoria } \\
\text { contínua }\end{array}$ & $\begin{array}{l}\text { O comprometimento } \\
\text { gerencial com a } \\
\text { melhoria continua é } \\
\text { evidente em toda a } \\
\text { organização. }\end{array}$ \\
\hline $\begin{array}{l}\text { 4. Gerenciamento } \\
\text { estratégico do } \\
\text { desempenho }\end{array}$ & $\begin{array}{l}\text { Foco em benefício de } \\
\text { curto prazo. }\end{array}$ & $\begin{array}{l}\text { É possível ligar as } \\
\text { iniciativas } \\
\text { melhoria com as } \\
\text { metas estratégicas do } \\
\text { negócio. }\end{array}$ & $\begin{array}{l}\text { Projetos são } \\
\text { mensurados para } \\
\text { avaliar sua } \\
\text { contribuição para as } \\
\text { metas estratégicas do } \\
\text { negócio. }\end{array}$ \\
\hline $\begin{array}{l}\text { 5. Treinamento e } \\
\text { aprendizado }\end{array}$ & $\begin{array}{l}\text { Treinamento é } \\
\text { realizado de forma } \\
\text { ad-hoc. }\end{array}$ & $\begin{array}{l}\text { Treinamento em } \\
\text { ferramentas básicas } \\
\text { de forma contínua. } \\
\text { Individuos e grupos } \\
\text { compartilham seu } \\
\text { aprendizado } \\
\text { experiência em todos } \\
\text { os níveis. }\end{array}$ & $\begin{array}{l}\text { Organização que } \\
\text { aprende através da } \\
\text { iniciativa de } \\
\text { melhoria contínua. } \\
\text { Todos estão } \\
\text { envolvidos na missão } \\
\text { de compartilhar } \\
\text { conhecimento e criar } \\
\text { uma organização que } \\
\text { aprende. }\end{array}$ \\
\hline $\begin{array}{l}\text { 6. Sistema } \\
\text { recompensa }\end{array}$ & $\begin{array}{l}\text { Não existe sistema } \\
\text { de recompensa. }\end{array}$ & $\begin{array}{l}\text { Sistema de } \\
\text { recompensa local. }\end{array}$ & $\begin{array}{l}\text { Sistema } \\
\text { recompensa } \\
\text { reconhecimento }\end{array}$ \\
\hline
\end{tabular}




\begin{tabular}{|l|l|l|l|l|}
\hline 7. Cultura de culpa & $\begin{array}{l}\text { Indivíduos com } \\
\text { receio de dar } \\
\text { sugestões; }\end{array}$ & $\begin{array}{l}\text { Suporte gerencial e } \\
\text { não punição a erros, } \\
\text { e sim encorajamento } \\
\text { a aprender com eles. }\end{array}$ & $\begin{array}{l}\text { Quando algo dá } \\
\text { errado, a reação } \\
\text { natural das pessoas é } \\
\text { a busca de razões ao } \\
\text { invés de culpados. }\end{array}$ \\
\hline 8. Comunicação & $\begin{array}{l}\text { Boa comunicação de } \\
\text { cima para baixo. }\end{array}$ & $\begin{array}{l}\text { Eficiente e eficaz } \\
\text { comunicação } \\
\text { vertical. }\end{array}$ & $\begin{array}{l}\text { Eficiente e eficaz } \\
\text { comunicação vertical } \\
\text { e horizontal. }\end{array}$ \\
\hline
\end{tabular}

Fonte: Adaptado de Fryer et al. (2013)

Segundo $\mathrm{Wu}$ e Chen (2006), para ser efetiva, a atividade de melhoria contínua percorre estágios progressivos de maturidade, representados no Quadro 12. O super-sistema, referenciado no último nível de maturidade, ocorre quando a estrutura e os processos organizacionais propiciam a criação de um ambiente de aprendizado e crescimento através da gestão do conhecimento e da prática rotineira de solução de problemas que agregam valor ao negócio como um todo.

Quadro 12 - Modelo de Wu e Chen sobre maturidade da melhoria contínua

\begin{tabular}{|l|l|}
\hline \multicolumn{1}{|c|}{ Estágio } & \multicolumn{1}{|c|}{ Alcance das iniciativas de melhoria } \\
\hline $\begin{array}{l}\text { 0. Iniciativas de } \\
\text { Solução }\end{array}$ & $\begin{array}{l}\text { A habilidade de solução de problemas não está claramente } \\
\text { presente. A abordagem utilizada é de eliminar sintomas. }\end{array}$ \\
\hline $\begin{array}{l}\text { 1. Modelos e } \\
\text { Ferramentas }\end{array}$ & $\begin{array}{l}\text { Empresa está aprendendo ferramentas e modelos apropriados de } \\
\text { solução de problemas. Poucas pessoas envolvidas no processo }\end{array}$ \\
\hline $\begin{array}{l}\text { 2. Modelos, } \\
\text { Ferramentas } \\
\text { combinados com } \\
\text { a Promoção }\end{array}$ & $\begin{array}{l}\text { Equipes de solução envolvendo toda a empresa. Reconhecimento } \\
\text { de soluções através de apresentações. Avaliação formal das } \\
\text { explícitos e demanda por treinamento aumenta. }\end{array}$ \\
\hline $\begin{array}{l}\text { 3. Enfoque } \\
\text { Estratégico }\end{array}$ & $\begin{array}{l}\text { Identificação de problemas a partir da estratégia. Habilidades em } \\
\text { inovação e gestão de processos são necessárias. }\end{array}$ \\
\hline $\begin{array}{l}\text { 4. Interação entre } \\
\text { os 3 componentes }\end{array}$ & $\begin{array}{l}\text { Problema deve ser aprofundado e a promoção está ligada a este } \\
\text { aprofundamento em especificidade. Ferramentas devem se ajustar }\end{array}$ \\
\hline
\end{tabular}




\begin{tabular}{|l|l|}
\hline & $\begin{array}{l}\text { ao problema. Empresa motivada em aprofundar e solucionar } \\
\text { problemas. Aplicação de habilidade de inovação e gestão de } \\
\text { processos e encontro de soluções ótimas através de } \\
\text { experimentação. }\end{array}$ \\
\hline $\begin{array}{l}\text { 5. Integração com } \\
\text { o super-sistema }\end{array}$ & $\begin{array}{l}\text { Identificação sistemática de problemas que agregam valor ao } \\
\text { negócio. Melhoria e inovação dos processos de negócio. } \\
\text { Estabelecimento de uma cultura de gestão do conhecimento. }\end{array}$ \\
\hline
\end{tabular}

Fonte: Chen e Wu, 2006, p. 701. Traduzido pelo Autor.

De forma semelhante a Chen e Wu (2006) García-Sabater, Marín-García e Perelló-Marín (2012) concluem a pesquisa com uma proposta de habilidades requeridas para cada um dos níveis de maturidade da melhoria contínua, apresentados no Quadro 13.

Quadro 13 - Facilitadores e Habilidades em cada Nível de Maturidade

\begin{tabular}{|l|l|l|}
\hline Estágio & Foco da Melhoria & Habilidades Requeridas \\
\hline $\begin{array}{l}\text { 1. Pré-Melhoria } \\
\text { Contínua }\end{array}$ & $\begin{array}{l}\text { Compreensão da } \\
\text { melhoria contínua }\end{array}$ & $\begin{array}{l}\text { Compreensão e formação de hábito de } \\
\text { melhoria contínua }\end{array}$ \\
\hline $\begin{array}{l}\text { 2. Melhoria } \\
\text { Contínua estruturada }\end{array}$ & $\begin{array}{l}\text { Compreensão da } \\
\text { melhoria contínua }\end{array}$ & $\begin{array}{l}\text { Liderar, promover e reconhecer resultados dos } \\
\text { projetos de melhoria contínua }\end{array}$ \\
\hline $\begin{array}{l}\text { 3.Melhoria Contínua } \\
\text { orientada a metas }\end{array}$ & $\begin{array}{l}\text { Foco em melhoria } \\
\text { contínua }\end{array}$ & $\begin{array}{l}\text { Coordenação de projetos multidisciplinares } \\
\text { pelo Gestor-Líder de Melhoria, metas } \\
\text { definidas pelos gestores }\end{array}$ \\
\hline $\begin{array}{l}\text { 4. Melhoria } \\
\text { Contínua proativa }\end{array}$ & Foco em melhoria & $\begin{array}{l}\text { Metodologia estruturada (sistema de produção } \\
\text { próprio), metas definidas pelo grupo }\end{array}$ \\
\hline $\begin{array}{l}\text { 5. Capacidade Plena } \\
\text { de Melhoria }\end{array}$ & $\begin{array}{l}\text { Melhoria } \\
\text { melhoria contínua }\end{array}$ & $\begin{array}{l}\text { Gestão do conhecimento, ferramentas } \\
\text { complexas de solução de problemas }\end{array}$ \\
\hline
\end{tabular}

Fonte: García-Sabater et al. (2012). Adaptado pelo Autor.

Do referencial teórico ligado a seleção e gerenciamento de projetos de melhoria contínua, podemos estabelecer as assertivas listadas no Quadro 14, a serem verificadas na pesquisa de campo. Ressalta-se que estão listados no Quadro 14 apenas as assertivas que não puderam ser inferidas dos referenciais teóricos analisados anteriormente. 
Quadro 14 - Assertivas identificadas a partir do referencial teórico sobre modelos de maturidade para melhoria contínua.

\begin{tabular}{|l|l|}
\hline Item & $\begin{array}{l}\text { Assertivas a partir do referencial teórico sobre modelos de maturidade para } \\
\text { melhoria contínua }\end{array}$ \\
\hline AS38 & $\begin{array}{l}\text { É necessário a adoção de um modelo de maturidade para formar e fortalecer uma } \\
\text { cultura de melhoria contínua que incentive os agentes internos a dar continuidade } \\
\text { dos projetos atuais e realizar novos projetos de melhoria. }\end{array}$ \\
\hline AS39 & É necessário tornar a melhoria contínua parte da rotina diária dos agentes internos. \\
\hline AS40 & É necessário estabelecer a melhoria do processo de melhoria contínua. \\
\hline AS41 & $\begin{array}{l}\text { É necessário remover a cultura da busca aos culpados pelos problemas, para que os } \\
\text { projetos sejam objetivos e não adotes viés politizado. }\end{array}$ \\
\hline
\end{tabular}

Fonte: elaborado pelo autor.

\subsection{Melhoria contínua como uma capacidade organizacional estratégica}

O estudo de múltiplos casos, realizado em 3 indústrias brasileiras, conduzido por Yen-Tsang et al. (2012) buscou avaliar preditores da capacidade organizacional de melhoria contínua. As proposições investigadas e comprovadas foram: P1 - O comportamento de melhoria continua é precedido pela intenção de realizá-la; P2 - A atitude, normalização e auto eficácia definem a intenção de realizar a melhoria contínua; P3 - Crenças subjetivas é a causa de cada uma das atitudes, normas e exemplos de auto eficácia.

A atitude favorável em relação ao aprendizado colaborativo, ao envolvimento de colaboradores e ao trabalho em equipe são exemplos de aspectos que formam a intenção de realizar a melhoria contínua. Requisitos de clientes, legislação e requisitos de sistemas de gestão das normas ISO são exemplos de normalização. A percepção de possuir a competência para implantar as melhorias necessárias em apoiar suas próprias rotinas é um exemplo de auto eficácia. Exemplos de crenças subjetivas individuais são trabalhar em time é mais produtivo que individual, devo sempre cumprir com os procedimentos ISO, tenho capacidade de contribuir com soluções criativas. A proposição pode ser diagramada conforme apresentado na Ilustração 4. 
Ilustração 4 - Preditores da capacidade de melhoria contínua

\begin{tabular}{|c|c|c|c|c|c|}
\hline P1 & P2 & P3 & & & \\
\hline $\begin{array}{l}\text { Crenças } \\
\text { subjetivas } \\
\text { individuais }\end{array}$ & $\begin{array}{l}\text { Atitude } \\
\text { Normalização }\end{array}$ & $\begin{array}{l}\text { Intenção } \\
\text { de realizar } \\
\text { a melhoria }\end{array}$ & $\begin{array}{l}\text { Comporta- } \\
\text { mento de } \\
\text { melhoria } \\
\text { contínua }\end{array}$ & $\begin{array}{l}\text { Rotinas } \\
\text { de } \\
\text { melhoria } \\
\text { contínua }\end{array}$ & $\begin{array}{l}\text { Capaci- } \\
\text { dade de } \\
\text { melhoria } \\
\text { contínua }\end{array}$ \\
\hline
\end{tabular}

Fonte: Adaptado de Yen-Tsang, Csillag e Siegler (2012)

A pesquisa de Yen-Tsang et al. (2012) tangencia a problemática do presente estudo, já que variáveis como intenção, atitude, auto eficácia e crenças são manifestadas na esfera da agência individual, representada pelo agente interno de melhoria, e a variável normalização é manifesta na esfera da institucionalização, representada pelo estudo do processo de transformação de profissionais nestes agentes.

Congruente com o trabalho de Yen-Tsang et al. (2012), Aloini, Martini e Pellegrini (2011) investigaram a melhoria contínua como uma capacidade que a organização deve desenvolver. Detectou-se uma incongruência entre a teoria normativa de melhoria continua representado por modelos de maturidade que seguem uma lógica de amadurecimento linear (Bessant et al., 2001; Fryer et al., 2013 ) e os estudos de caso e levantamentos que não seguem esta mesma lógica. Na lógica linear, por exemplo, a organização inicia a jornada sem nenhuma estrutura formal de melhoria, passa a adotar uma estrutura de equipes de melhoria até ter uma estrutura onde a rotina do dia-a-dia já incorporou a tarefa de melhoria em todas as funções e níveis organizacionais. A conclusão da pesquisa indica que empresas que adotaram uma lógica linear de desenvolvimento da capacidade de melhoria contínua possuem desempenho operacional significativamente maior em relação a aquelas que seguiram um padrão não linear, corroborando com a importância de adoção de um modelo de maturidade para melhoria contínua. Isto implica que a implantação da melhoria contínua é como o deslizar de uma bola de neve: as empresas devem ser pacientes ao implementar, pois não existem atalhos para desenvolver esta capacidade (Wenbin \& Hongyi, 2009). 
Huang, Rode e Schroeder (2011) testaram as seguintes proposições numa pesquisa com 266 empresas do setor industrial: P1 - Uma estrutura organizacional orgânica está relacionada com a melhoria contínua e aprendizado; P2 - Esta relação é mais fortalecida em culturas nacionais que endossam a liderança participativa; P3 - Uma cultura de grupo na organização é mais importante dentro de culturas nacionais que não endossam a liderança participativa. A pesquisa foi conduzida de em vários países para identificar a influência da cultura nacional: asiática representada por Japão e Coreia do Sul, latina europeia representada por Itália e Espanha, nórdica europeia representada por Finlândia e Suécia, germânica europeia representada por Áustria e Alemanha, e anglo representada pelos Estados Unidos. Os resultados comprovaram que as proposições P1, P2 e P3. Destaca-se o fato da cultura de grupo, variável organizacional independente da cultura nacional, não precisar ser forte quando a cultura nacional endossa a liderança participativa, indicando que a iniciativa para a melhoria contínua é favorecida em culturas nacionais de empresas nórdicas, germânicas ou norteamericanas. Infere-se que no caso brasileiro, mais próximo das culturas latinas, o fomento a uma cultura de grupo dentro da organização tem papel fundamental na promoção de melhoria contínua, já que o contexto nacional não favorece a liderança participativa.

Quadro 15 - Assertivas identificadas a partir do referencial teórico sobre melhoria contínua como uma capacidade organizacional estratégica.

\begin{tabular}{|l|l|}
\hline Item & $\begin{array}{l}\text { Assertivas a partir do referencial teórico sobre melhoria contínua como uma } \\
\text { capacidade organizacional estratégica }\end{array}$ \\
\hline AS42 & $\begin{array}{l}\text { É necessário que cada agente interno de melhoria tenha uma atitude favorável em } \\
\text { relação a dar continuidade aos projetos atuais e iniciar novos projetos de melhoria. }\end{array}$ \\
\hline AS43 & $\begin{array}{l}\text { É necessário o estabelecimento de uma normalização para os agentes internos que } \\
\text { requeira a continuidade dos projetos atuais e iniciar novos projetos de melhoria. }\end{array}$ \\
\hline AS44 & $\begin{array}{l}\text { É necessário que os agentes internos tenham uma percepção de auto eficácia ao } \\
\text { possuir a competência para realizar projetos de melhoria. }\end{array}$ \\
\hline AS45 & $\begin{array}{l}\text { É necessário que haja a paciência gerencial e dos próprios agentes com a colheita } \\
\text { dos resultados dos projetos de melhoria. }\end{array}$ \\
\hline AS46 & $\begin{array}{l}\text { É necessário o fomento de uma cultura de trabalho em equipe e autonomia, já que } \\
\text { o contexto cultural brasileiro não favorece a liderança participativa ou a autonomia } \\
\text { para iniciativa. }\end{array}$ \\
\hline
\end{tabular}

Fonte: elaborado pelo autor. 


\section{PROCEDIMENTO METODOLÓGICO}

O objetivo principal deste trabalho é descrever e analisar como tornar mais efetivos os esforços de transformação de profissionais, membros da organização, em agentes internos de melhoria na indústria automobilística. A fim de se atingir o objetivo principal, foram delineados sete objetivos específicos:

1) Relatar as experiências de intervenções de capacitação dos agentes internos de melhoria.

2) Sumarizar os principais achados oriundos das teorias pesquisadas a fim de formar um referencial teórico.

3) Realizar um estudo de campo empírico nas empresas que passaram pelas intervenções de capacitação, coletando distintas fontes de evidência sobre os resultados e percepções dos processos de capacitação realizados.

4) Comparar, o referencial teórico e pesquisa de campo, a fim de identificar elementos relevantes na transformação efetiva de profissionais, membros da organização, em agentes internos de melhoria contínua da indústria automobilística.

5) Prover uma lista de recomendações à teoria acadêmica, ao identificar aderências e lacunas em relação ao referencial teórico.

6) Prover uma lista de recomendações à prática gerencial, ao propor novos cursos de ação para os casos estudados.

O primeiro objetivo específico foi atendido por meio da seção 2, relato da experiência, onde os elementos presentes nos modelos de intervenção realizados foram descritos para as três montadoras consideradas neste estudo. O segundo objetivo específico foi obtido por meio de levantamento bibliográfico orientado a identificar elementos já apontados na literatura acadêmica como relevantes em relação a transformação efetiva de profissionais em agentes internos de melhoria contínua. Este capítulo apresenta a descrição do estudo empírico realizado para atender o terceiro objetivo específico, o que inclui a definição do tipo de pesquisa, a metodologia e procedimentos empregados para análise dos resultados. O quarto objetivo específico será tratado na seção 5 , análise de resultados. A seção 6 , conclusões e considerações finais, atenderá o quinto e sexto objetivos específicos desta pesquisa. 
A questão de pesquisa configura o presente estudo como qualitativo e de caráter exploratório. A pesquisa qualitativa também pode ser utilizada quando deseja-se obter novos pontos de vista sobre coisas das quais já se conhece bastante (Strauss \& Corbin, 2008), como é o caso da melhoria contínua. O caráter é exploratório porque se procura entender o complexo fenômeno transformação de profissionais em agentes internos de melhoria, com ênfase na ampliação de conhecimentos (Godoy, 1995). Complexidade explicada pela multiplicidade de variáveis atuantes: atores envolvidos, estrutura organizacional requerida, interação com demais iniciativas de gestão de operações, cultura organizacional e nacional, importação de modelos gerenciais de matrizes das montadoras, conteúdo e abordagem de aprendizagem na formação dos agentes, critérios de seleção e coordenação de projetos, apenas para citar algumas delas.

A metodologia de pesquisa é o estudo de caso. O autor descreve que o escopo do estudo de caso é:

“... uma investigação empírica que investiga um fenômeno contemporâneo em profundidade e em seu contexto de vida real, especialmente quando os limites entre o fenômeno e o contexto não são claramente evidentes" (Yin, 2010, pp. 39).

Yin (2010) ainda enfatiza que com a investigação do estudo de caso enfrenta a situação tecnicamente diferenciada em que existirão muito mais variáveis de interesse do que pontos de dados, e, como resultado:

- conta com múltiplas fontes de evidência, com os dados precisando convergir de maneira triangular, e

- beneficia-se do desenvolvimento anterior das proposições teóricas para orientar a coleta e a análise de dados. (pp.40)

Destaca-se a participação do presente pesquisador e da equipe de consultoria como observadores participantes, o que gerou o benefício de proporcionar fontes objetivas de evidência, como relatórios e observações in loco. Desta forma a descrição das intervenções de capacitação realizadas pela consultoria nas três montadoras e o contexto organizacional de cada uma delas é uma aplicação legítima para utilizar a metodologia de estudo de caso, porque descreverá uma intervenção e o contexto da vida real na qual ela ocorreu e explorará 
situações em que a intervenção sendo avaliada não possui um único e claro conjunto de resultados.

\subsection{Projeto de Pesquisa}

Os cinco componentes do projeto de pesquisa para os estudos de caso são: as questões do estudo, as proposições, quando existirem, as unidades de análise, a lógica que vincula os dados às proposições e os critérios de interpretação dos achados (Yin, 2010).

\subsubsection{Questão do estudo}

A questão de pesquisa elaborada com base no objetivo principal de pesquisa é:

- Quais elementos são relevantes na transformação efetiva de profissionais, membros da organização, em agentes internos de melhoria contínua, na indústria automobilística?

\subsubsection{Proposições}

O referencial teórico foi identificado e selecionado a partir de artigos acadêmicos alinhados com o objetivo principal e questão de pesquisa. Quarenta e seis assertivas emergiram como elementos relevantes na transformação de profissionais em agentes internos de melhoria, que é o escopo deste estudo (Yin, 2010). As listas com todas as assertivas estão apresentadas no Apêndice 1.

Para facilitar a análise dos resultados, as assertivas foram agrupadas em torno do tema central a que elas se referem, tornando-se proposições teóricas a serem investigadas na pesquisa de campo.

As assertivas AS1, AS2, AS4, AS31, AS45 estão ligadas ao papel da alta direção e do nível gerencial, de onde se pode propor as seguintes proposições teóricas:

- P1: A transformação de profissionais, membros da organização, em agentes internos de melhoria deve ser vista como uma ação estratégica da alta direção. 
- P2: A transformação de profissionais, membros da organização, em agentes internos de melhoria requer um investimento de tempo e participação dos gestores no apoio a realização de projetos de melhoria.

As assertivas que tratam da importância da seleção dos agentes internos de melhoria são AS3, AS27, AS28, AS42, AS44. Delas se infere as seguintes proposições teóricas:

- P3: Os profissionais selecionados para se tornarem agentes internos de melhoria devem demonstrar atitude favorável à melhoria e perceber-se capaz de realizar projetos de melhoria. Isto engloba perceber-se capaz de aprender a realizar projetos de melhoria e também acreditar que haverá o respaldo suficiente para realizar projetos de melhoria na sua organização.

- P4: Os profissionais selecionados para se tornarem agentes internos de melhoria devem conhecer as metas organizacionais e estarem no nível organizacional adequado com a maturidade do programa. Isto significa que se a atividade de melhoria contínua não estiver disseminada e com estrutura de apoio estabelecida, os profissionais selecionados deverão estar num nível hierárquico maior, suficiente para que haja autonomia e autoridade para realizar projetos. Em suma, quanto menos madura a melhoria contínua, maior o nível hierárquico necessário.

As assertivas que tratam da importância do desenvolvimento das competências dos agentes internos e a abordagem de aprendizagem adotada são AS5, AS7, AS10, AS22, AS23. AS36 e AS37. Delas se infere as seguintes proposições teóricas:

- P5: Deve-se desenvolver a habilidade do agente interno de melhoria em aplicar na prática uma metodologia e ferramentas de solução de problemas de acordo com o tipo de projeto e dos processos organizacionais.

- P6: Deve-se desenvolver a habilidade do agente interno de melhoria em gerenciamento de tempo, gerenciamento de conflito, delegação, aceitação a mudança e pensamento sistêmico.

As assertivas que tratam da importância do papel do coordenador de melhoria são AS6 e AS19. Delas se infere a seguinte proposição teórica:

- P7: O coordenador de melhoria contínua deve ser escolhido cuidadosamente e ter dedicação de tempo integral na função. 
As assertivas que tratam da importância da gestão dos projetos de melhoria são AS8, AS11, AS12, AS13, AS14, AS17, AS21, AS24, AS26, AS32, AS33, AS34 e AS35, de onde formula-se as seguintes proposições:

- P8: O projeto deve ter objetivo mensurável, alinhado com a estratégia organizacional, de apuração de resultado não ambígua.

- P9: Deve ser estabelecido um processo de gestão do conhecimento, capaz de resgatar e utilizar o conhecimento gerado em projetos anteriores, que facilite a condução de novos projetos otimizando o estado futuro já alcançado em projetos anteriores.

- P10: Deve estar implantada uma sistemática de seleção de projetos com critérios objetivos e uma função de coordenação de portfólio de projetos.

- P11: Cada projeto de melhoria deve contar com uma equipe adequada a sua complexidade, com comunicação efetiva e regular entre a equipe e outras funções e níveis organizacionais.

As assertivas que tratam da importância de normalização e de incentivos para estimular a condução de projetos de melhoria são AS15, AS16, AS20 e AS43. Delas se infere a seguinte proposição teórica:

- P12: Devem ser criados mecanismos de normalização e de incentivo a continuidade de atuação através de novos projetos de melhoria, que cheguem até o nível dos operadores.

As assertivas que tratam da importância criação de um ambiente de colaboração são AS25, AS29, AS30, AS41 e AS46, de onde formula-se as seguintes proposições:

- P13: Deve ser fomentado um ambiente de colaboração para com o agente interno, o que inclui canal de comunicação para esclarecimentos durante o projeto, valorização de trabalho em equipe e da autonomia.

- P14: Deve ser atacada intencionalmente a cultura de busca aos culpados dos problemas.

As assertivas que tratam da importância da adoção de um modelo de maturidade para melhoria contínua são AS38, AS39 e AS40, de onde formula-se as seguintes proposições: 
- P15: Deve ser adotado um modelo de maturidade para formar e fortalecer uma cultura de melhoria, incluindo a melhoria do próprio processo de melhoria.

A assertiva AS18 trata da questão da estabilidade do processo, e será considerada uma proposição adicional:

- P16: É necessário assegurar a estabilidade dos equipamentos para que os projetos de melhoria realizados pelos agentes internos tenham resultados sustentáveis.

As proposições serão checadas diretamente através de evidências objetivas como observações diretas, observações participantes, ou seja, relatos onde o pesquisador estava participando da realização de atividades, e análise de documentos e de registros. Os documentos e registros avaliados incluem relatórios de cada projeto de melhoria, atas de reunião, painéis de indicadores de desempenho e planos de ação e foram analisados pelo pesquisador durante visitas in loco nas montadoras, mas não puderam ser disponibilizados por motivos de confidencialidade das informações.

Adicionalmente as proposições serão checadas indiretamente através de entrevistas, utilizando questionário não estruturado, com demais consultores externos, coordenadores dos programas de melhoria das montadoras e agentes internos e gestores, conforme demonstrado no Quadro 16. No Quadro 16 as proposições são relacionadas com as questões de pesquisa descritas nos questionários dos agentes internos, simbolizados pela letra $\mathrm{A}$, gestores, simbolizados pela letra $\mathrm{G}$, coordenadores de melhoria, simbolizados pela letra $\mathrm{C}$ e consultores externos, simbolizados pelas letras $\mathrm{CE}$, respectivamente nas quatro últimas colunas da direita do quadro. Após a descrição de cada proposição é colocado entre parêntesis as letras I ou A, classificando cada proposição entre relacionada com a institucionalização ou com a agência humana respectivamente. Os números apresentados abaixo das letras $\mathrm{A}, \mathrm{G}, \mathrm{C}$ e $\mathrm{CE}$ são os mesmos que identificam as questões de pesquisa dos anexos 1, 2, 3 e 4 .

Ao invés de realizar um levantamento de campo para testar de forma explícita as 16 proposições, escolheu-se aqui o uso de entrevistas individuais com questionários não estruturados para não induzir os participantes a afirmar proposições politicamente corretas. Lembre-se que uma das contribuições desta pesquisa é descrever e preencher a lacuna entre a teoria esposada e a teoria realmente em uso destas iniciativas de melhoria contínua e, 
portanto, um levantamento ou entrevista com assertivas de melhores práticas traria o risco de conter um conjunto de respostas com significativo viés de reflexividade, quando o entrevistado dá ao entrevistador o que ele quer ouvir (Yin, 2010). Enfim, questionário de entrevista conterá apenas tópicos, dado o caráter exploratório da presente pesquisa. Quando a questão de pesquisa esta relacionada com a proposição aparecerá o tema da questão, que tipo de ator entrevistado foi pesquisado e o número de referência da questão no respectivo questionário. 
Quadro 16 - Relação entre as proposições teóricas e as questões de pesquisa com Agentes internos (A), Gestores (G), Coordenadores (C) e Consultores externos (CE).

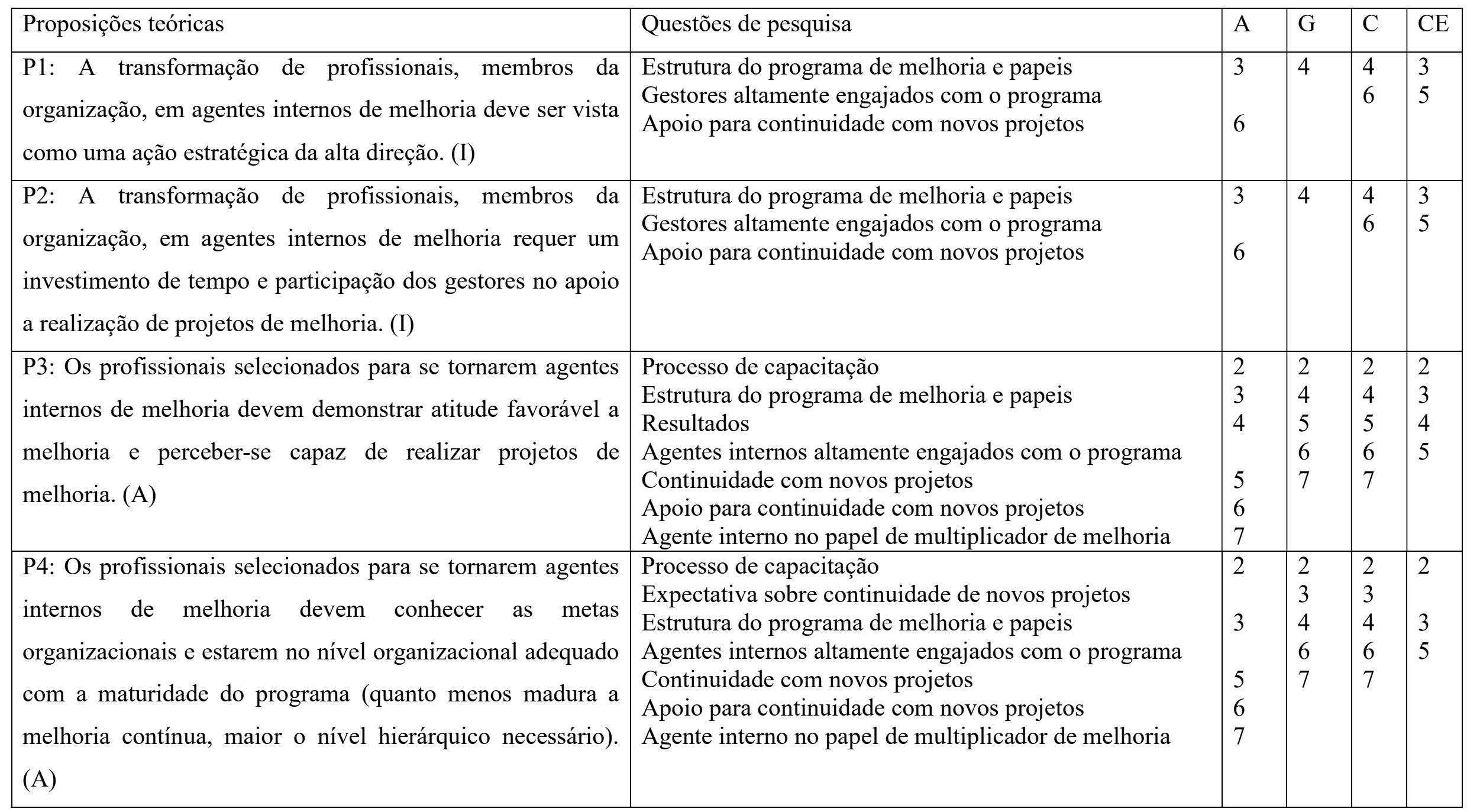


Quadro 16 - Relação entre as proposições teóricas e as questões de pesquisa com Agentes internos (A), Gestores (G), Coordenadores (C) e Consultores externos (CE).

\begin{tabular}{|c|c|c|c|c|c|}
\hline Proposições teóricas & Questões de pesquisa & A & G & $\mathrm{C}$ & $\mathrm{CE}$ \\
\hline $\begin{array}{l}\text { P5: Deve-se desenvolver a habilidade do agente interno de } \\
\text { melhoria em aplicar na prática uma metodologia e } \\
\text { ferramentas de solução de problemas de acordo com o tipo } \\
\text { de projeto e dos processos organizacionais. (I) }\end{array}$ & Processo de capacitação & 2 & 2 & 2 & 2 \\
\hline $\begin{array}{l}\text { P6: Deve-se desenvolver a habilidade do agente interno de } \\
\text { melhoria em gerenciamento de tempo, gerenciamento de } \\
\text { conflito, delegação, aceitação a mudança e pensamento } \\
\text { sistêmico. (A) }\end{array}$ & Processo de capacitação & 2 & 2 & 2 & 2 \\
\hline $\begin{array}{l}\text { P7: O coordenador de melhoria contínua deve ser escolhido } \\
\text { cuidadosamente e ter dedicação de tempo integral na } \\
\text { função. (I) }\end{array}$ & $\begin{array}{l}\text { Estrutura do programa de melhoria e papeis } \\
\text { Apoio para continuidade com novos projetos }\end{array}$ & $\begin{array}{l}3 \\
6\end{array}$ & 4 & 4 & 3 \\
\hline
\end{tabular}


Quadro 16 - Relação entre as proposições teóricas e as questões de pesquisa com Agentes internos (A), Gestores (G), Coordenadores (C) e Consultores externos (CE).

\begin{tabular}{|c|c|c|c|c|c|}
\hline Proposições teóricas & Questões de pesquisa & A & $\mathrm{G}$ & $\mathrm{C}$ & $\mathrm{CE}$ \\
\hline $\begin{array}{l}\text { P9: Deve ser estabelecido um processo de gestão do } \\
\text { conhecimento, capaz de resgatar e utilizar o } \\
\text { conhecimento gerado em projetos anteriores, que } \\
\text { facilite a condução de novos projetos otimizando o } \\
\text { estado futuro já alcançado em projetos anteriores. (I) }\end{array}$ & $\begin{array}{l}\text { Expectativa sobre continuidade de novos projetos } \\
\text { Estrutura do programa de melhoria e papeis } \\
\text { Resultados } \\
\text { Apoio para continuidade com novos projetos }\end{array}$ & $\begin{array}{l}3 \\
4 \\
6\end{array}$ & $\begin{array}{l}3 \\
4 \\
5\end{array}$ & $\begin{array}{l}3 \\
4 \\
5\end{array}$ & $\begin{array}{l}3 \\
4\end{array}$ \\
\hline $\begin{array}{l}\text { P11: Cada projeto de melhoria deve contar com uma } \\
\text { equipe adequada a sua complexidade, com } \\
\text { comunicação efetiva e regular entre a equipe e } \\
\text { outras funções e níveis organizacionais. (I) }\end{array}$ & $\begin{array}{l}\text { Processo de capacitação } \\
\text { Expectativa sobre continuidade de novos projetos } \\
\text { Estrutura do programa de melhoria e papeis } \\
\text { Resultados } \\
\text { Apoio para continuidade com novos projetos }\end{array}$ & $\begin{array}{l}2 \\
3 \\
4 \\
6\end{array}$ & $\begin{array}{l}2 \\
3 \\
4 \\
5\end{array}$ & $\begin{array}{l}2 \\
3 \\
4 \\
\mp\end{array}$ & $\begin{array}{l}2 \\
3 \\
4\end{array}$ \\
\hline
\end{tabular}


Quadro 16 - Relação entre as proposições teóricas e as questões de pesquisa com Agentes internos (A), Gestores (G), Coordenadores (C) e Consultores externos (CE).

\begin{tabular}{|c|c|c|c|c|c|}
\hline Proposições teóricas & Questões de pesquisa & A & $\mathrm{G}$ & $\mathrm{C}$ & $\mathrm{CE}$ \\
\hline $\begin{array}{l}\text { P13: Deve ser fomentado um ambiente de } \\
\text { colaboração para com o agente interno, o que inclui } \\
\text { canal de comunicação para esclarecimentos durante } \\
\text { o projeto, valorização de trabalho em equipe e da } \\
\text { autonomia. (I) }\end{array}$ & $\begin{array}{l}\text { Processo de capacitação } \\
\text { Estrutura do programa de melhoria e papeis } \\
\text { Gestores altamente engajados com o programa } \\
\text { Continuidade com novos projetos } \\
\text { Apoio para continuidade com novos projetos }\end{array}$ & $\begin{array}{l}2 \\
3 \\
5 \\
6\end{array}$ & $\begin{array}{l}2 \\
4\end{array}$ & $\begin{array}{l}2 \\
4 \\
6 \\
7\end{array}$ & $\begin{array}{l}2 \\
3 \\
5\end{array}$ \\
\hline $\begin{array}{l}\text { P15: Deve ser adotado um modelo de maturidade } \\
\text { para formar e fortalecer uma cultura de melhoria, } \\
\text { incluindo a melhoria do próprio processo de } \\
\text { melhoria. (I) }\end{array}$ & $\begin{array}{l}\text { Processo de capacitação } \\
\text { Expectativa sobre continuidade de novos projetos } \\
\text { Estrutura do programa de melhoria e papeis } \\
\text { Resultados } \\
\text { Gestores altamente engajados com o programa } \\
\text { Continuidade com novos projetos } \\
\text { Apoio para continuidade com novos projetos }\end{array}$ & $\begin{array}{l}2 \\
3 \\
5 \\
6\end{array}$ & $\begin{array}{l}2 \\
3 \\
4\end{array}$ & $\begin{array}{l}2 \\
3 \\
4 \\
6 \\
7\end{array}$ & $\begin{array}{l}2 \\
3 \\
5\end{array}$ \\
\hline $\begin{array}{l}\text { P16: É necessário assegurar a estabilidade dos } \\
\text { equipamentos para que os projetos de melhoria } \\
\text { realizados pelos agentes internos tenham resultados } \\
\text { sustentáveis. (I) }\end{array}$ & $\begin{array}{l}\text { Estrutura do programa de melhoria e papeis } \\
\text { Resultados }\end{array}$ & $\begin{array}{l}3 \\
4\end{array}$ & $\begin{array}{l}4 \\
5\end{array}$ & $\begin{array}{l}4 \\
5\end{array}$ & $\begin{array}{l}3 \\
4\end{array}$ \\
\hline
\end{tabular}

Fonte: elaborado pelo autor. 


\subsubsection{Unidades de análise}

Yin (2010) aponta para três situações onde um estudo de caso único deveria ser realizado: o caso representa todos os aspectos de uma teoria bem formulada, trata-se de um caso extremo ou único ou quando, devido às circunstâncias, representa uma oportunidade única de estudo pelo pesquisador. No presente estudo nenhuma destas condições é satisfeita, o que implica na necessidade de realizar um estudo de múltiplos casos: três plantas produtivas de montadoras multinacionais instaladas no Brasil. A escolha das montadoras foi baseada na sua aderência a questão de pesquisa e devido ao acesso a informações sobre a atividade de melhoria contínua, pois o autor atuou como consultor externo para as referidas montadoras realizando treinamentos e acompanhamentos de projetos de melhoria durante o período do estudo.

Neste trabalho, a unidade de análise considerada será o processo de transformação de profissionais em agentes internos de melhoria, desde a contratação da consultoria externa até a conclusão dos projetos de certificação final dos agentes internos de melhoria. $\mathrm{O}$ foco a ser dado em cada unidade de análise será híbrido, parte integrado, parte holístico.

As montadoras A e C serão consideradas um caso único, por serem duas plantas fabris do mesmo grupo automobilístico, entretanto unidades integradas de análise distintas. As montadoras A e C estão localizadas em cidades diferentes, com diretores de planta diferentes, mas com funções centrais e presidente de grupo em comum.

A montadora B será considerada outro caso, sem unidades dentro de si, o que significa uma unidade de análise holística. Isso permitirá identificar semelhanças e diferenças entre casos e entre unidades integradas dentro do mesmo caso (Yin, 2010), ou seja, será possível analisar dados e realizar comparações entre montadoras e dentro de plantas do mesmo grupo automobilístico.

Os fatos relevantes para caracterizar a atividade de melhoria contínua das três montadoras serão analisados a partir de múltiplas fontes de evidência: observações diretas e participantes, análise de documentos, análise de registros e entrevistas, de forma a assegurar uma triangulação adequada dos dados (Yin, 2010). 
Entre os anos de 2012 a 2014 foram analisados dados e eventos relativos desenvolvimento e aplicação do processo de formação dos agentes internos de melhoria, incluindo acompanhamento e implantação de projetos de melhoria.

Um caráter longitudinal está presente nesta pesquisa, pois a observação direta in loco e a condução das entrevistas com os principais atores do programa de melhoria em cada montadora foi realizada no primeiro semestre de 2016, cerca de 2 anos após a conclusão das intervenções de capacitação. A proposta é avaliar, até que ponto os agentes treinados continuaram com a implantação de novos projetos de melhoria no intervalo de um a dois anos após a capacitação inicial, uma medida objetiva de eficácia na sustentação do programa.

Foram realizadas entrevistas não estruturadas com os agentes de melhoria e seus gestores, coordenadores e consultores externos que participaram do programa entre 2012 a 2014 . O próprio pesquisador realizou as entrevistas utilizando um questionário com perguntas abertas, de forma a permitir a flexibilidade necessária à natureza exploratória da pesquisa. $\mathrm{O}$ roteiro para as entrevistas de cada um destes atores está descrito nos anexos 1 a 4 .

Entre março e maio de 2016 foram entrevistados todos os 4 consultores externos que participaram do programa de capacitação nas montadoras A, B e C. Adicionalmente foram entrevistados 1 coordenador, 1 gestor e 3 agentes internos de melhoria da Montadora A, 1 coordenador, 1 gestor e 4 agentes internos de melhoria da Montadora B, 1 coordenador, 1 gestor e 1 agente interno de melhoria da Montadora C. No total foram 17 entrevistas em aproximadamente 25 horas, que serviram de base para elaboração dos relatórios individuais de caso, apresentados na seção 5. Durante a entrevista o pesquisador revisava o roteiro e conduzia questões de esclarecimento de declarações ambíguas ou nebulosas. As informações e declarações mais relevantes oriundas das entrevistas das montadoras A, B e C são apresentadas nos Apêndices 2, 3 e 4, respectivamente. As informações e declarações dos consultores terão a função de triangular os achados a partir de observações diretas e participantes do presente pesquisador, que também atuava como consultor nos processos de capacitação das três montadoras estudadas. 


\subsubsection{Lógica que vincula os dados às proposições}

A análise dos resultados será realizada na seção 5. Primeiro serão relatadas as observações diretas e participantes e os documentos e registros ligados as proposições teóricas descritas no Apêndice 1, depois elas serão comparadas com os resultados das entrevistas, para avaliar sua relevância, fechando esta etapa de triangulação de dados (Yin, 2010). Esta análise será realizada de maneira individual para cada montadora e depois de maneira conjunto, comparando resultados entre as três montadoras. Isto porque Eisenhardt (1989) ressalta que a análise individual dos casos é uma etapa fundamental para construção de teoria a partir do estudo de casos múltiplos.

\subsubsection{Critérios de interpretação dos achados}

Yin (2010) enfatiza que a meta do método do estudo de caso é expandir e generalizar teorias, generalização analítica, e não enumerar frequências, generalização estatística. Uma série de precauções foi tomada para assegurar critérios de interpretação robustos.

Destacam-se os seguintes cuidados metodológicos para estabelecer as conclusões: uso de questionário durante entrevistas, entrevista conduzida pelo próprio pesquisador com interação e esclarecimentos de informações junto ao entrevistado, triangulação das múltiplas fontes de evidência, triangulação dos achados a partir da observação direta e participante, através da consideração de relatos dos 4 consultores que participaram ativamente dos processos de capacitação.

Para identificar os elementos relevantes da transformação efetiva de profissionais, membros da organização, em agentes internos de melhoria contínua, as proposições serão classificadas nas categorias aderência elevada, aderência moderada, sem aderência. Por aderência entendese o grau em que a proposição pôde ser confirmada pelas múltiplas fontes de evidência, ou seja, a relevância de cada uma das proposições teóricas. O propósito desta classificação é identificar os elementos com alta relevância na transformação de profissionais, membros da organização, em agentes internos de melhoria contínua, no caso desta pesquisa, aquelas classificadas como de aderência elevada. Os critérios para realizar esta classificação estão descritos nos Quadro 17. 
Quadro 17 - Critérios de classificação da aderência das proposições teóricas.

\begin{tabular}{|c|c|}
\hline $\begin{array}{l}\text { Classificação da } \\
\text { proposição }\end{array}$ & Critérios para classificação \\
\hline $\begin{array}{l}\text { Aderência } \\
\text { elevada }\end{array}$ & $\begin{array}{l}\text { Pelo menos um relato oriundo das entrevistas de agentes, gestores e } \\
\text { coordenadores nas três montadoras estudadas diretamente ligados a } \\
\text { confirmação da proposição. } \\
\text { Relatórios e outras fontes objetivas de evidência nas três montadoras } \\
\text { diretamente ligados a confirmação da proposição. } \\
\text { Observações diretas do pesquisador ligadas a confirmação da } \\
\text { proposição. }\end{array}$ \\
\hline $\begin{array}{l}\text { Aderência } \\
\text { moderada }\end{array}$ & $\begin{array}{l}\text { Pelo menos um relato de algum dos atores das montadoras estudadas, } \\
\text { com relação indireta ou não explícita com a proposição. } \\
\text { Pelo menos um relatório ou outra fonte objetiva de evidência de alguma } \\
\text { das três montadoras com relação indireta ou não explícita com a } \\
\text { proposição. } \\
\text { Observações diretas do pesquisador confirmam parcialmente a } \\
\text { proposição. }\end{array}$ \\
\hline Sem aderência & $\begin{array}{l}\text { Ausência de relatos que confirmem parcialmente ou totalmente a } \\
\text { proposição. Relatos tangenciam o tema da proposição, mas não } \\
\text { confirmam sua validade. } \\
\text { Relatórios ou outras fontes de evidência objetiva não confirmam a } \\
\text { validade da proposição ou até mesmo são contrários a proposição. } \\
\text { Observações diretas do pesquisador não confirmam a proposição ou até } \\
\text { mesmo são contrários a proposição. }\end{array}$ \\
\hline
\end{tabular}

Fonte: elaborado pelo autor. 


\section{ANÁLISE DE RESULTADOS}

A análise de resultados das pesquisas nas montadoras A, B e C está descrita nos itens 5.1, 5.2 e 5.3, respectivamente. Dois elementos foram analisados em cada montadora: entrevistas e fontes documentais. O conjunto de declarações dos coordenadores, gestores e agentes internos das montadoras A, B e C são apresentadas no Apêndice 2, 3 e 4, respectivamente. Exemplos de documentos observados nas montadoras A, B e C são apresentados nos apêndices 5, 6 e 7, respectivamente.

A análise de resultados de cada montadora inicia-se com uma sumarização de afirmações relevantes dos coordenadores de melhoria, gestores e agentes internos. Posteriormente foram descritos os principais achados ligados as fontes documentais pesquisadas. Da integração destes dois elementos foram traçadas as conclusões sobre a eficácia da capacitação dos agentes internos de melhoria em cada montadora.

Uma comparação dos resultados obtidos nas três montadoras está descrita no item 5.4. Por fim, no item 5.5, são apresentadas as conclusões relativas a classificação da relevância das proposições teóricas para que ocorra a transformação efetiva de profissionais, membros da organização, em agentes internos de melhoria contínua, que é o objetivo principal desta pesquisa.

\subsection{Montadora A}

O sumário das afirmações do coordenador de melhoria, gestor e agentes internos estão descritos nos itens 5.1.1, 5.1.2 e 5.1.3.

5.1.1) Resultados da entrevista com o coordenador de melhoria da Montadora A

Baseado no Apêndice 2, podemos sumarizar as seguintes afirmações coletadas durante a entrevista com o coordenador de melhoria da Montadora A:

a) Contratação da consultoria teve o propósito de ajudar na coordenação e suporte aos projetos dos agentes internos durante a capacitação inicial.

b) O consultor deve compreender questões políticas e rotina da empresa.

c) O ideal: agente interno como agente transformador. 
d) O agente deve saber utilizar de forma apropriada, e não apenas burocrática, as ferramentas.

e) Existem pessoas que adotaram para si o papel de agente, e se não encontraram espaço para aplicar a melhoria, saíram e foram para outras empresas para tal.

f) Resultados iniciais satisfatórios, porém, com baixo índice de transformação de profissionais em agentes internos de melhoria.

g) Alta direção não precisa de conhecimento aprofundado nas ferramentas, mas precisa acreditar e não ser imediatista na solução de problemas.

h) Na Montadora A é preciso convencer cada gestor. Na Montadora $\mathrm{C}$, ao convencer o diretor de planta, todos seguem as suas diretrizes.

i) Coordenador deve conhecer profundamente a metodologia e ter habilidades políticas.

j) Nem sempre um profissional experiente é um bom agente interno.

k) $\mathrm{O}$ gestor deve liderar o caminho, estabelecendo metas desafiadoras e apoiando a condução do projeto.

1) $\mathrm{O}$ gestor deve quebrar as barreiras departamentais para que o projeto possa fluir.

m) A grande dificuldade do agente é transformar seu tema em prioridade para outras áreas.

n) Profissionais experientes que aprenderam a resolver problemas sem a metodologia são mais resistentes a aplicar projetos de melhoria de forma estruturada. O gestor deve mapear e atuar próximo a estes casos.

o) A consultoria deveria fazer um trabalho de mudança atitudinal, tornando as pessoas mais favoráveis a realização de projetos de melhoria.

p) RH e Controladoria são funções de suporte que deveriam ser envolvidas no programa.

q) Os resultados de uma década do programa comprovam seu benefício.

r) A atitude favorável do agente interno é fundamental para a continuidade de novos projetos de melhoria.

s) O coordenador deve ter habilidades de negociação e influência.

t) O orçamento do programa de capacitação não pode estar alocado na função qualidade e sim no RH.

u) A controladoria deve avaliar os resultados dos projetos de forma independente, senão em momentos de crise não se mantém a estrutura do programa.

v) Reduções de custo sem visão sistêmica de seu impacto no longo prazo minaram a estrutura do programa. 


\subsection{2) Resultados da entrevista com um gestor da Montadora A}

Baseado no Apêndice 2, podemos sumarizar as seguintes afirmações coletadas durante a entrevista com o gestor da Montadora A:

a) Contratação da consultoria teve o propósito fomentar o programa de melhoria.

b) A alta direção deve comprar a filosofia de aplicação de metodologia estruturada para resolução de problemas.

c) O gestor deve acompanhar semanalmente os projetos dos agentes de sua equipe.

d) A alta direção deve fomentar os gestores a fomentarem projetos de melhoria.

e) A alta direção não pode aceitar soluções paliativas, que não ataquem a causa raiz.

f) A falta de tempo para se dedicar aos projetos acaba gerando soluções ineficazes e os problemas acabam recorrendo.

g) $\mathrm{O}$ coordenador melhoria e o seu gestor não tinha força junto a direção para exigir maior apoio de tempo dedicado para a realização dos projetos.

h) O nível de apoio dos gestores variava muito, e isto afeta significativamente o resultado dos projetos dos agentes de suas equipes.

i) Em áreas ligadas a solução de problemas, projetos de melhoria tem maiores chances de integração com a rotina.

j) O gestor precisa conhecer a metodologia de solução de problemas.

k) $\mathrm{O}$ agente interno deve acreditar nas ferramentas e metodologia, ter vontade de aprender, aprender e depois aplicar.

1) $\mathrm{O}$ agente interno deve ter desenvolvida a capacidade analítica, conhecimento técnico do processo onde está realizando o projeto e ser um negociador.

m) $\mathrm{O}$ agente interno deve monitorar as ações de melhoria até que o novo método esteja enraizado.

n) A própria estrutura de trabalho da área deveria monitorar a implantação das melhorias, mas não faz isso devido a rotina ter inúmeras tarefas a serem feitas.

o) O alinhamento com a estratégica de negócio deveria ser direto, pois cada projeto deveria ser um projeto de interesse do CEO.

p) Se o gestor valorizar e apoiar, os agentes acabam realizando novos projetos.

q) Quando o agende acredita que a metodologia de projetos de melhoria representa uma oportunidade de crescimento dentro ou fora da empresa, há maior chance de dar continuidade com novos projetos de melhoria. 
r) A necessidade de soluções rápidas e sua suficiência diante da grande variedade de problemas é um grande risco a construção de ações de melhoria robustas.

s) Na Montadora C, a aplicação da metodologia foi muito mais efetiva, devido o apoio do diretor de planta.

5.1.3) Resultados das entrevistas com os agentes internos de melhoria da Montadora A

Baseado no Apêndice 2, podemos sumarizar as seguintes afirmações coletadas durante as entrevistas com os agentes de melhoria da Montadora A:

Afirmações do agente A1

a) Aplicação de metodologia em garantia dá resultados expressivos, o que pode reforçar sua aceitação pessoal e apoio gerencial.

b) Aplicação de metodologia ficou muito focada a problemas e a projetos da área da qualidade.

c) É importante o acompanhamento de projetos por especialistas internos no processo, para validar ações e análises, as vezes muito técnicas.

d) $\mathrm{O}$ agente deve conseguir treinar o diretor cético quanto a metodologia e ele passou a acreditar que em alguns problemas a metodologia deveria ser aplicada.

e) Um diretor com conhecimento técnico consegue apoiar muito através de não aceitar soluções paliativas.

f) Os melhores projetos se originam do pessoal com grande conhecimento técnico prévio.

g) Apenas a presença do presidente em uma reunião mensal sobre problemas de qualidade de garantia já foi suficiente para mobilizar estruturas de outros departamentos, como a engenharia.

h) A crise não afetou a continuidade de novos projetos de melhoria na área de garantia, apenas mudou o enfoque de melhoria da qualidade para redução de custos de forma robusta.

i) A internalização da melhoria contínua ocorre para alguns agentes de forma muito forte.

j) A maior alavancagem é quando a alta direção internaliza a importância de usar metodologia na busca da melhoria contínua. 
Afirmações do agente A2

a) A abordagem de treinamento com caso real ajuda muito a realização de projeto e entender a metodologia.

b) Equilíbrio de apagar logo o incêndio, mas não parar o projeto antes de ações definitivas.

c) Mudou o gestor, a área parou de aplicar metodologia em projetos de melhoria. O perfil de promoção dos gestores deve ser considerado ao realizar promoções

d) Incentivo errado: fazer cursos ou abrir novos projetos

e) O apoio ao projeto inicial era muito mais forte do que para novos projetos.

f) A liberação de verba para investimento em soluções identificadas nos projetos de melhoria precisa de critérios claros e objetivos.

g) É muito importante o agente interno explicar o que está acontecendo para a equipe, não apenas usar o tempo e conhecimento dela.

Afirmações do agente A3

a) Pressão de tempo acaba reduzindo a qualidade dos projetos, então deveria ser ensinado como otimizar o tempo de análise e condução de projeto.

b) Etapa de padronização mal realizada minava a qualidade dos projetos.

c) A alta direção deveria apoiar e comprometer-se explicitamente com a realização de novos projetos.

d) O coordenador deve avaliar o grau de dificuldade dos projetos e ajudar os agentes a selecionarem projetos apropriados ao nível de recursos existentes para realizá-los..

e) O gestor deve ajudar o desenvolvimento técnico e comportamental, em especial a atitude de ter segurança ao demonstrar seu projeto em situações não politicamente favoráveis.

f) Em funções que demandam análise e solução de problemas, os projetos de melhoria são incorporados na rotina de maneira natural e consistente.

g) Os funcionários em fim de carreira tendem a não iniciar novos projetos. Mas também existem aqueles que adotam a postura de omissão e só fazem se forem pressionados.

5.1.4) Principais achados a partir da análise de projetos da Montadora A 
Devido a confidencialidade das informações, os projetos de melhoria e demais documentos do programa de melhoria não foram liberados para cópia ou fotografia, portanto as constatações aqui são produto de anotações realizadas pelo pesquisador. A Ilustração 5 apresenta, de forma gráfica, os resultados dos projetos de melhoria analisados.

Ilustração 5 - Acompanhamento de Projetos na Montadora A

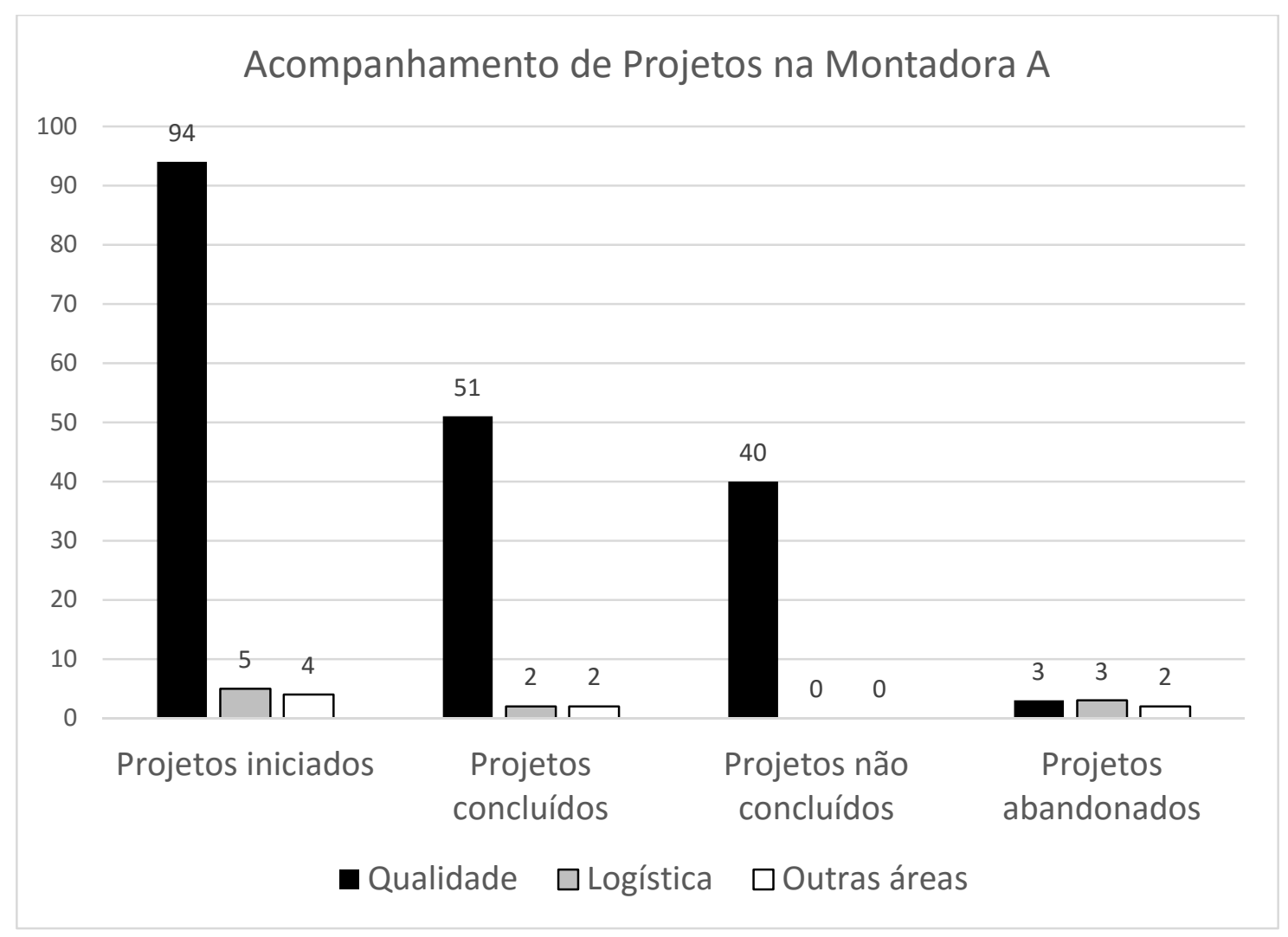

Fonte: elaborado pelo autor.

O sumário da análise dos projetos de melhoria na Montadora A está descrito no Quadro 18.1. O sumário da análise de outras fontes de evidência coletadas na Montadora A está descrito no Quadro 18.2. 
Quadro 18.1 - Análise de projetos realizados na Montadora A.

\begin{tabular}{|c|c|}
\hline $\begin{array}{l}\text { Documento e tipo de } \\
\text { informação coletada }\end{array}$ & $\begin{array}{l}\text { Sumário dos principais achados após análise do(s) } \\
\text { documento(s) }\end{array}$ \\
\hline $\begin{array}{l}\text { Planilha de controle de } \\
\text { projetos - modelo contido no } \\
\text { Apêndice 5: Listagem com } \\
\text { todos os projetos de melhoria } \\
\text { iniciados incluindo: os nomes } \\
\text { dos agentes de melhoria, } \\
\text { gestores e time, o título e } \\
\text { metas do projeto e a situação } \\
\text { de projeto. }\end{array}$ & $\begin{array}{l}103 \text { projetos de melhoria iniciados: } 94 \text { projetos ligados a } \\
\text { redução de defeitos e melhoria da qualidade do produto, } 5 \\
\text { projetos ligados a melhoria de atividades ligadas a logística } \\
\text { e } 4 \text { projetos ligados a outras áreas. O programa ficou dentro } \\
\text { da área de qualidade da montadora e, portanto, com } \\
\text { participação quase exclusiva do pessoal desta área. }\end{array}$ \\
\hline 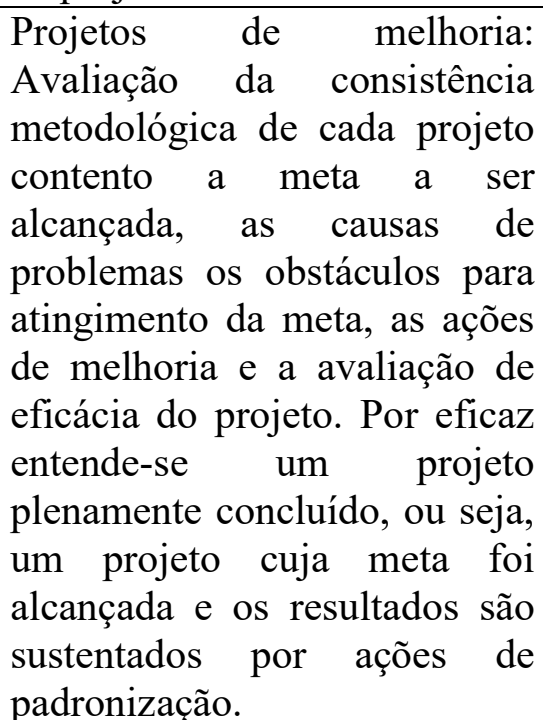 & $\begin{array}{l}\text { Apenas } 55 \text { projetos foram concluídos. Dos } 48 \text { projetos } \\
\text { restantes, } 8 \text { foram abandonados e } 40 \text { projetos foram } \\
\text { considerados não satisfatórios por não estarem plenamente } \\
\text { concluídos dentro do prazo estabelecido. Os } 38 \text { agentes de } \\
\text { melhoria cujo gestores participaram ativamente das reuniões } \\
\text { de acompanhamento tiveram seus projetos plenamente } \\
\text { concluídos. Destacam-se as seguintes fragilidades nos } \\
\text { projetos não concluídos: adoção de soluções paliativas } \\
\text { devido à baixa autonomia para modificar processos } \\
\text { produtivos, em especial nos projetos visando eliminação de } \\
\text { defeitos de qualidade ligados a fatores humanos, } \\
\text { impossibilidade de verificação da eficácia das ações de } \\
\text { melhoria e da sustentação dos resultados e a falta de } \\
\text { padronização do conhecimento ganho com o projeto. }\end{array}$ \\
\hline $\begin{array}{l}\text { Planilha de acompanhamento } \\
\text { de projetos - modelo contido } \\
\text { no Apêndice 5: avaliação da } \\
\text { participação dos gestores }\end{array}$ & $\begin{array}{l}\text { Foram realizadas } 6 \text { visitas de acompanhamento de projeto, } \\
\text { espaçadas de } 3 \text { a } 4 \text { semanas entre si. Apenas } 38 \text { projetos } \\
\text { contaram com a participação dos gestores nas reuniões de } \\
\text { acompanhamento. Merece destaque os dois gestores da área } \\
\text { de garantia da qualidade, os únicos que participaram de } \\
\text { todas as } 6 \text { reuniões previstas para o acompanhamento do } \\
\text { projeto inicial usado para qualificar cada agente interno de } \\
\text { melhoria. O coordenador tentava substituir o apoio gerencial } \\
\text { nos projetos em que o gestor não participou ativamente, mas } \\
\text { quando era necessárias mudanças significativas em } \\
\text { processos produtivos para solução de problemas, este apoio } \\
\text { não foi efetivo. }\end{array}$ \\
\hline $\begin{array}{l}\text { Planilha de acompanhamento } \\
\text { de projetos: avaliação da } \\
\text { participação das agentes }\end{array}$ & $\begin{array}{l}\text { Em } 17 \text { projetos sem a participação dos gestores os agentes } \\
\text { foram bem-sucedidos. Pode-se observar nestes casos que: o } \\
\text { escopo do projeto estava bem definido desde a entrevista } \\
\text { inicial com a consultoria, o agente conseguiu obter apoio do } \\
\text { líder e equipe de produção da área ligada ao projeto. }\end{array}$ \\
\hline
\end{tabular}

Fonte: elaborado pelo autor. 
Quadro 18.2 - Análise de outras fontes de evidência observadas na Montadora A.

\begin{tabular}{|c|c|}
\hline Fonte de evidência & Sumário dos principais achados e conclusões \\
\hline $\begin{array}{l}\text { Apresentação } \\
\text { gerencial do } \\
\text { programa de } \\
\text { melhoria }\end{array}$ & $\begin{array}{l}\text { Extrato do documento "criação de uma cultura de melhoria contínua } \\
\text { através da abertura de projetos de melhoria de forma sistemática e } \\
\text { contínua. " Confirma-se que a expectativa da Montadora A foi a de } \\
\text { formar profissionais capazes de realizar projetos de melhoria de forma } \\
\text { contínua. }\end{array}$ \\
\hline $\begin{array}{l}\text { Atas de reunião } \\
\text { para seleção de } \\
\text { projeto }\end{array}$ & $\begin{array}{l}\text { Foram realizadas reuniões de confirmação de projeto a ser conduzido } \\
\text { por cada agente de melhoria. O senso prático de viabilidade de } \\
\text { atingimento da meta era de responsabilidade do gestor e do senso de } \\
\text { consistência na definição do escopo de projeto era de responsabilidade } \\
\text { da consultoria. Em pelo menos } 15 \text { projetos houve a mudança de tema } \\
\text { por falta de viabilidade de atingimento da meta. }\end{array}$ \\
\hline $\begin{array}{l}\text { Planilha de controle } \\
\text { de projetos não } \\
\text { ligados ao } \\
\text { treinamento inicial }\end{array}$ & $\begin{array}{l}\text { Durante o ano de } 2015 \text { e primeiro semestre de } 2016 \text { foram realizados } \\
21 \text { projetos de melhoria pelos agentes internos capacitados. Foram } \\
\text { projetos ligados a solução de problemas crônicos de qualidade ou } \\
\text { ligados a extensão de ações de melhoria a projetos similares. Com a } \\
\text { crise econômica de } 2016 \text { o programa de melhoria perdeu sua estrutura } \\
\text { de apoio, incluindo o acompanhamento de projetos e o deslocamento } \\
\text { do coordenador de melhoria para o desempenho de outro papel na área } \\
\text { de qualidade. }\end{array}$ \\
\hline $\begin{array}{l}\text { Projetos de } \\
\text { melhoria não } \\
\text { formalmente } \\
\text { controlados }\end{array}$ & $\begin{array}{l}\text { Merece destaque a área de garantia de qualidade, onde os agentes } \\
\text { treinados continuaram a utilizar a metodologia de melhoria para } \\
\text { resolver problemas a peças retornadas de campo. Isto é relevante } \\
\text { porque demonstra que o papel desempenhado tem influência na } \\
\text { transformação do profissional em agente de mudança. } \\
\text { Outro caso que merece destaque refere-se a um dos profissionais } \\
\text { treinados que continua realizando projetos de melhoria, e o faz } \\
\text { escondido do chefe imediato porque acredita na metodologia como } \\
\text { ferramenta de trabalho. Isto reforça a importância do aspecto de } \\
\text { agência humana não só em conjunto com a institucionalização, mas } \\
\text { também na ausência de mecanismos de institucionalização. Este } \\
\text { profissional continua a realizar projetos numa condição adversa, onde a } \\
\text { chefia não permite a alocação de tempo para tanto por acreditar ser um } \\
\text { desperdício de tempo. }\end{array}$ \\
\hline
\end{tabular}

Fonte: elaborado pelo autor.

Considerando as informações levantadas nas entrevistas, a análise do resultado dos projetos e demais documentos e observações diretas do pesquisador podemos concluir que na Montadora A não ocorreu uma transformação efetiva dos profissionais treinados em agentes internos de melhoria. 


\subsection{Montadora B}

O sumário das afirmações do coordenador de melhoria, gestor e agentes internos estão descritos nos itens 5.2.1, 5.2.2 e 5.2.3.

\subsection{1) Resultados da entrevista com o coordenador de melhoria da Montadora B}

Baseado no Apêndice 3, podemos sumarizar as seguintes afirmações coletadas durante a entrevista com o coordenador de melhoria da Montadora B:

a) A busca de projetos de melhoria contínua é um requisito do grupo e a consistência e profundidade dos projetos é parte de um indicador que compara o nível de maturidade em excelência das operações entre plantas do grupo.

b) O líder de produção é a função mais importante de aderir a realização dos projetos de melhoria.

c) Os melhores líderes foram promovidos ou mudaram de área.

d) O bom projeto é aquele que realiza a integração com demais pilares para garantir a sustentabilidade dos resultados.

e) O papel do RH na área é fundamental para ouvir as demandas dos gestores e alinhar expectativas com a consultoria.

f) Capacitação em imersão gera uma visão sistêmica da excelência em cada agente.

g) Alta direção e gestores não pode aceitar no dia a dia apenas soluções paliativas.

h) Em áreas produtivas ligadas a montagem há uma tendência maior de projetos imediatistas serem aceitos. $\mathrm{Na}$ área de transformação, como pintura, a tendência é analisar os parâmetros de processo, a máquina, o meio ambiente, tornando mais crítica a análise de sugestões de melhoria.

i) Coordenador de pilar deve estar presente na fábrica.

j) Melhoria pode ser restauração de padrões ou estabelecimento de novos padrões.

k) Adaptação dos materiais a exemplos da planta ajuda a quebra de resistências a aplicação de metodologia e ferramentas de melhoria.

1) A implantação de área modelo é a melhor maneira de começar a melhoria num setor.

m) A grande dificuldade do agente é transformar seu tema em prioridade para outras áreas. 
5.2.2) Resultados da entrevista com um gestor de melhoria da Montadora B

Baseado no Apêndice 3, podemos sumarizar as seguintes afirmações coletadas durante a entrevista com o gestor da Montadora B:

a) Contratação da consultoria teve o propósito de trazer um treinamento prático para que os agentes internos pudessem elaborar projetos de melhoria e auxiliassem a implantação dos pilares do modelo de excelência em suas áreas.

b) O gestor deve acompanhar o projeto inicial de cada agente interno de melhoria da sua equipe.

c) O modelo de maturidade com avaliações periódicas e com a alta direção cobrando a melhoria da pontuação, faz com que a melhoria seja desdobrada para os gestores, líderes e até operadores.

d) A estrutura do modelo de maturidade em passos ou etapas favorece a identificação de lacunas de desempenho ou de padronização, que favorece a realização de projetos de melhoria sistematicamente.

e) $\mathrm{O}$ gestor que conhece a metodologia apoia muito mais assertivamente. $\mathrm{O}$ treinamento do gestor é fundamental para ele não se sentir "ultrapassado" pelo líder de sua equipe que foi treinado como agente interno de melhoria.

5.2.3) Resultados das entrevistas com os agentes internos de melhoria da Montadora B

Baseado no Apêndice 3, podemos sumarizar as seguintes afirmações coletadas durante as entrevistas com os agentes de melhoria da Montadora B:

Afirmações do agente A1

a) A abordagem prática do treinamento com apresentações acabou auxiliando o agente interno no trabalho em equipe.

b) $\mathrm{O}$ treinamento precisa conter desafios atitudinais ligados aos valores esperados pela empresa.

c) A comunicação dos objetivos do processo de capacitação deve ser feita claramente pela alta direção, sob o risco de gerar percepções negativas da importância de realizar projetos de melhoria. 
a) Aplicação de metodologia em projeto real é fundamental para o agente interno adquirir segurança na aplicação de metodologia nos projetos de melhoria.

b) Ao cobrar pelos projetos a direção deve mostrar-se disponível por participar dos mesmos, ou seja, liderar o caminho.

c) Os coordenadores devem estar presentes para que os novos projetos tenham um suporte após o término da capacitação inicial, já que a figura do consultor externo desaparece neste momento.

d) O líder de produção deve empoderar-se como dono do processo de melhoria de sua área.

Afirmações do agente A3

a) Aprender a trabalhar com metodologia foi muito valorizado pelos agentes da Montadora B.

b) É necessário desenvolver nos gestores uma visão de foco nos processos e não apenas foco nos resultados.

Afirmações do agente A4

a) Aprender a trabalhar com metodologia foi muito valorizado pelos agentes da Montadora B.

\subsection{4) Principais achados a partir da análise de projetos da Montadora B}

Devido a confidencialidade das informações, os projetos de melhoria e demais documentos do programa de melhoria não foram liberados para cópia ou fotografia, portanto as constatações aqui são produto de anotações realizadas pelo pesquisador. A Ilustração 6 apresenta, de forma gráfica, os resultados dos projetos de melhoria analisados.

Ilustração 6 - Acompanhamento de Projetos na Montadora B 


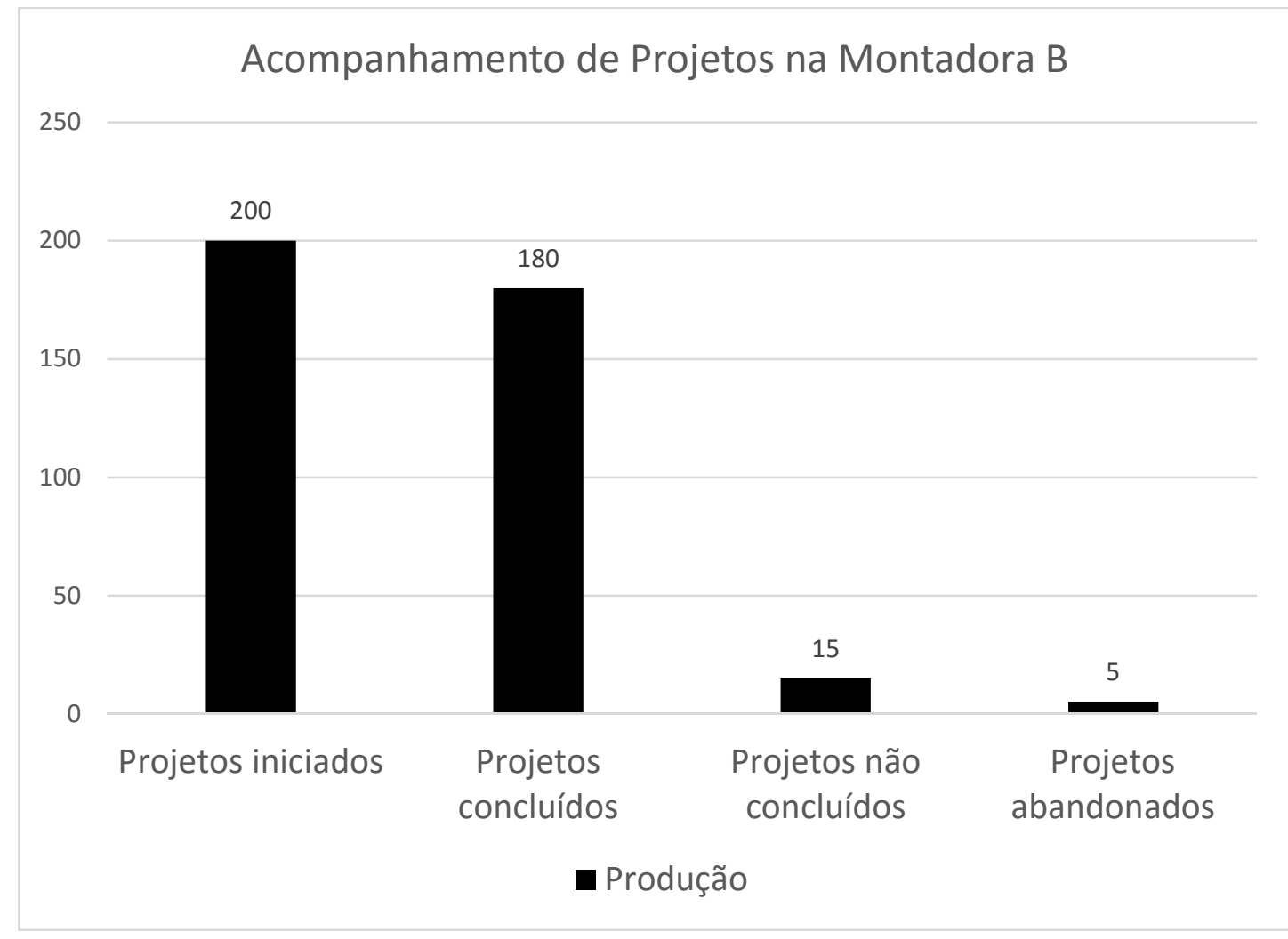

Fonte: elaborado pelo autor.

O sumário da análise dos projetos de melhoria na Montadora B está descrito no Quadro 19.1. O sumário da análise de outras fontes de evidência coletadas na Montadora B está descrito no Quadro 19.2.

Quadro 19.1 - Análise de projetos realizados na Montadora B.

\begin{tabular}{|c|c|}
\hline $\begin{array}{l}\text { Documento e tipo de } \\
\text { informação coletada }\end{array}$ & $\begin{array}{l}\text { Sumário dos principais achados após análise do(s) } \\
\text { documento(s) }\end{array}$ \\
\hline $\begin{array}{l}\text { Planilha de avaliação de } \\
\text { projetos }- \text { modelo contido no } \\
\text { Apêndice 6: Listagem com } \\
\text { todos os projetos de melhoria } \\
\text { iniciados incluindo: os nomes } \\
\text { dos agentes de melhoria e seus } \\
\text { projetos e a avaliação } \\
\text { quantitativa de consistência } \\
\text { metodológica de cada etapa do } \\
\text { projeto. }\end{array}$ & $\begin{array}{l}200 \text { projetos de melhoria iniciados, todos conduzidos por } \\
\text { líderes de produção de todas as oficinas da montadora: } \\
\text { estamparia, soldagem, pintura e montagem. Diferentemente } \\
\text { das montadoras A e C, não houve concentração de projetos } \\
\text { em torno de defeitos de qualidade do produto. Projetos } \\
\text { ligados a ganhos de eficiência produtiva foram a maioria, } \\
\text { destacando-se: redução de retrabalho, redução de tempo de } \\
\text { operação e tempo de preparação, melhoria da confiabilidade } \\
\text { de equipamento, redução de materiais consumíveis. } \\
\text { Redução de impactos ambientais e de riscos de segurança } \\
\text { ocupacional. O programa de treinamento foi amplamente } \\
\text { expandido para todas as oficinas da área de produção da } \\
\text { montadora e em suas } 6 \text { semanas de imersão em tempo }\end{array}$ \\
\hline
\end{tabular}




\begin{tabular}{|c|c|}
\hline & $\begin{array}{l}\text { integral abrangeu métodos e ferramentas dos pilares de } \\
\text { manufatura classe mundial e desenvolvimento de } \\
\text { competências comportamentais ligadas a liderança, } \\
\text { comunicação, delegação, trabalho em equipe e } \\
\text { administração do tempo. }\end{array}$ \\
\hline $\begin{array}{l}\text { Planilha de avaliação de } \\
\text { projetos - modelo contido no } \\
\text { Apêndice 6: Listagem com } \\
\text { todos os projetos de melhoria } \\
\text { iniciados incluindo: os nomes } \\
\text { dos agentes de melhoria e seus } \\
\text { projetos e a avaliação } \\
\text { quantitativa de consistência } \\
\text { metodológica de cada etapa do } \\
\text { projeto. }\end{array}$ & $\begin{array}{l}180 \text { projetos foram concluídos plenamente. Os } 15 \text { projetos } \\
\text { que foram considerados não satisfatórios ocorreram na área } \\
\text { de montagem. Observou-se que eles tenderam a restaurar } \\
\text { padrões de trabalho ao invés de eliminar causas e barreiras } \\
\text { da estabilidade do processo, o que é chave para a } \\
\text { sustentação dos resultados alcançados. A avaliação de } \\
\text { consistência do projeto teve o resultado negativo porque as } \\
\text { fragilidades tecnológicas do processo produtivo } \\
\text { continuaram presentes mesmo após a implantação das ações } \\
\text { de melhoria. }\end{array}$ \\
\hline $\begin{array}{l}\text { Reunião de apresentação de } \\
\text { tarefas pós módulos de } \\
\text { treinamento, incluindo avanço } \\
\text { dos projetos }\end{array}$ & $\begin{array}{l}\text { No início de cada uma das } 6 \text { semanas de treinamento, os } \\
\text { agentes tinham um momento de apresentar as evidências } \\
\text { relacionadas as tarefas pós treinamento, incluindo avanço } \\
\text { dos projetos, onde os gestores eram convidados a participar. } \\
\text { Alguns gestores compareciam nestes dias, mas o verdadeiro } \\
\text { apoio gerencial realizado foi o tempo em que os gestores } \\
\text { substituíram os líderes na rotina de liderança de produção e } \\
\text { permitiram a realização de projetos e implantação de } \\
\text { práticas de excelência em suas áreas. }\end{array}$ \\
\hline $\begin{array}{l}\text { Comunicados e memorandos } \\
\text { relativos a avaliação da } \\
\text { participação dos agentes }\end{array}$ & $\begin{array}{l}\text { A troca de correio eletrônico com a consultoria era um } \\
\text { processo de apoio muito importante na capacitação destes } \\
\text { líderes. Por estarem em regime de imersão eles realizavam } \\
\text { seus projetos e no caso de dúvidas mantinham o contato } \\
\text { contínuo com o consultor. Parte dos agentes era de uma } \\
\text { nova geração de engenheiros de produção participante de } \\
\text { um programa de trainees da montadora e outra parte era de } \\
\text { profíssionais com escolaridade técnica, porém atuando há } \\
\text { mais de } 20 \text { anos na fábrica. As dificuldades típicas dos } \\
\text { trainees eram de agilidade e autonomia, pois dependiam } \\
\text { mais do conhecimento técnico do gestor que os mentoriava. } \\
\text { As dificuldades típicas dos líderes experientes eram } \\
\text { documentar o projeto, pois como descrito pelo diretor de } \\
\text { planta em entrevista adicional, estes líderes são do tipo } \\
\text { "carregadores de piano" e preferem a "mão na massa". No } \\
\text { entanto em ambos os casos, a grande maioria consegui } \\
\text { completar plenamente os projetos. }\end{array}$ \\
\hline
\end{tabular}

Fonte: elaborado pelo autor. 
Quadro 19.2 - Análise de outras fontes de evidência observadas na Montadora B.

\begin{tabular}{|c|c|}
\hline Fonte de evidência & Sumário dos principais achados e conclusões \\
\hline $\begin{array}{l}\text { Materiais de apoio } \\
\text { ao programa de } \\
\text { manufatura classe } \\
\text { mundial }\end{array}$ & $\begin{array}{l}\text { A estrutura do programa de manufatura classe mundial conta com uma } \\
\text { ampla gama de manuais gerenciais e metodológicos para cada pilar de } \\
\text { excelência. A contínua realização de projetos de melhoria é um dos } \\
\text { valores essenciais do programa. }\end{array}$ \\
\hline $\begin{array}{l}\text { Atas de reunião } \\
\text { para seleção de } \\
\text { projeto }\end{array}$ & $\begin{array}{l}\text { Os projetos eram selecionados ao consultar a planilha de gestão } \\
\text { industrial, que auxiliou o agente a selecionar projetos que atacassem } \\
\text { perdas relevantes e bem documentadas pela empresa. Este sistema } \\
\text { apresentou-se muito robusto e não ocorreram mudanças de temas de } \\
\text { projetos no meio do programa de capacitação. }\end{array}$ \\
\hline $\begin{array}{l}\text { Planilha de gestão } \\
\text { industrial e } \\
\text { Matrizes de Perdas } \\
\text { e Riscos }\end{array}$ & $\begin{array}{l}\text { Uma planilha de controle de todos os projetos é monitorada pelo } \\
\text { escritório de manufatura classe mundial. Ela contém uma estratificação } \\
\text { detalhada de diversos tipos de perdas na área industrial. A partir dela, } \\
\text { qualquer líder pode saber qual a principal perda de seu processo por } \\
\text { tipo de perda, por operação, por tipo de veículo, por turno de trabalho e } \\
\text { por período de tempo. Esta poderosa ferramenta que leva o agente a } \\
\text { focar em perdas localizadas que são reconhecidas pela empresa, por } \\
\text { estarem ligadas ao sistema de coleta de dados de desempenho da } \\
\text { fábrica. O gerenciamento destas perdas é pauta da reunião de } \\
\text { monitoramento do desempenho de gerentes e supervisores, portanto, } \\
\text { todos os agentes têm apoio gerencial praticamente imediato para iniciar } \\
\text { projetos que ataquem estas perdas. Após a capacitação inicial, os } \\
\text { agentes internos de melhoria capacitados realizaram } 715 \text { projetos de } \\
\text { melhoria, entre os anos } 2015 \text { e } 2016 \text {. }\end{array}$ \\
\hline $\begin{array}{l}\text { Exame de } \\
\text { conhecimento }\end{array}$ & $\begin{array}{l}\text { No final do processo de capacitação, os líderes realizaram uma } \\
\text { avaliação de conhecimento sobre o método e ferramentas utilizadas em } \\
\text { projetos de melhoria. Os líderes mais experientes e com baixa } \\
\text { escolaridade tiveram sistematicamente notas mais baixas no exame, que } \\
\text { testava a capacidade cognitiva ao apresentar cenários teóricos de } \\
\text { aplicação de ferramentas de melhoria. }\end{array}$ \\
\hline $\begin{array}{l}\text { Projetos de } \\
\text { melhoria sistêmica }\end{array}$ & $\begin{array}{l}\text { O modelo de maturidade WCM, adotado pela montadora } \mathrm{B} \text {, prevê a } \\
\text { implantação de melhores práticas de gestão de operações quanto à } \\
\text { qualidade, desdobramento de custos, organização do posto de trabalho, } \\
\text { logística, manutenção autônoma, manutenção profissional e preventiva, } \\
\text { desenvolvimento de pessoas, segurança e meio ambiente. Este tipo de } \\
\text { melhoria é chamado de projeto de melhoria sistêmica, que é apoiado } \\
\text { por } 11 \text { profissionais na função de coordenador de pilar. Nele não se } \\
\text { foca numa perda específica, mas na adoção de práticas que removam } \\
\text { fragilidades sistêmicas de cada processo produtivo e aumente sua } \\
\text { estabilidade. Os líderes de produção são responsáveis pela implantação } \\
\text { integrada dos pilares, pois está é uma das principais atribuições de seus } \\
\text { cargos. O nível de maturidade de cada área produtiva compõe um } \\
\text { indicador de desempenho de planta que tem como responsável o diretor } \\
\text { de planta. Auditorias semestrais realizadas por uma equipe que realiza } \\
\text { avaliações e comparações de desempenho industrial entre as plantas do }\end{array}$ \\
\hline
\end{tabular}




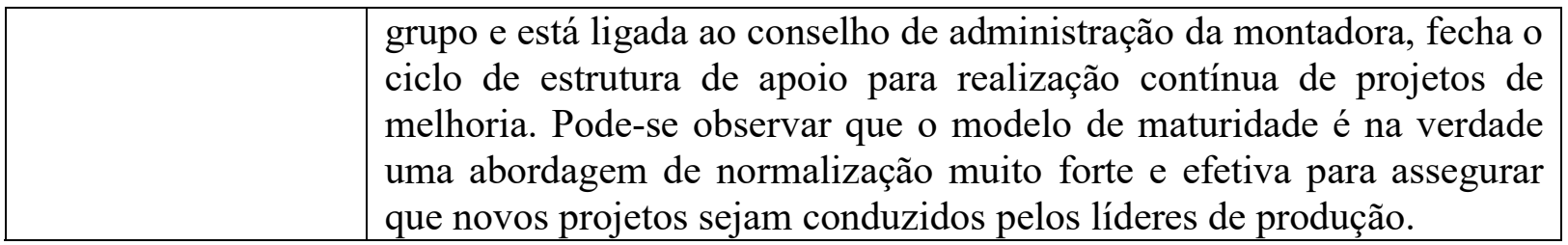

Fonte: elaborado pelo autor.

Considerando as informações levantadas nas entrevistas, a análise do resultado dos projetos e demais documentos e observações diretas do pesquisador podemos concluir que na Montadora B ocorreu a transformação efetiva dos profissionais treinados em agentes internos de melhoria.

\subsection{Montadora C}

O sumário das afirmações do coordenador de melhoria, gestor e agentes internos estão descritos nos itens 5.3.1, 5.3.2 e 5.3.3.

5.3.1) Resultados da entrevista com o coordenador de melhoria da Montadora C

Baseado no Apêndice 4, podemos sumarizar as seguintes afirmações coletadas durante a entrevista com o coordenador de melhoria da Montadora C:

a) O apoio do diretor de planta foi decisivo para a quantidade e qualidade dos projetos.

b) O uso de métricas não só financeiras para avaliar o resultado dos projetos foi muito importante para concluir alguns projetos.

c) $\mathrm{O}$ resultado financeiro inicial apareceu, mas com a mudança de diretoria perde-se a estrutura de monitoramento dos projetos.

d) Foi implantado um processo formal de reporte de resultados e avançamento de projetos, fundamental para manter os projetos dentro do prazo e objetivos.

e) A alta direção estabeleceu um diálogo com todos os níveis de operações para identificar projetos relevantes.

f) A alta direção estabeleceu um canal de comunicação direto com o coordenador de melhoria contínua. 
g) $\mathrm{O}$ agente interno deve apresentar as informações com robustez e com segurança, para evitar a falta de confiança do gestor na qualidade das informações.

h) Embora se reconheça o papel da alta direção, quando um gestor internaliza a importância de usar metodologia de melhoria, ele estabelece esta prática na rotina de sua equipe.

i) Em empresas com sistemática de avaliação de desempenho, os projetos de melhoria deveriam fazer parte das dimensões avaliadas.

j) É importante avaliar este perfil no momento da seleção e prover o desenvolvimento comportamental dos agentes que forem participar do programa.

k) É necessário que haja o alinhamento de metas do projeto com prioridades e objetivos da área do agente interno e de áreas de interface.

\subsection{2) Resultados da entrevista com o gestor de melhoria da Montadora C}

O gestor escolhido para entrevista atuou como gestor nas duas plantas, montadoras A e C, respectivamente, portanto as informações desta entrevista já foram descritas no item 5.1.2. Quando ocorreram, as diferenças percebidas pelo gestor entre a montadoras A e C foram descritas nas próprias afirmações descritas no item 5.1.2.

5.3.3) Resultados da entrevista com o agente interno de melhoria da Montadora C

Baseado no Apêndice 4, podemos sumarizar as seguintes afirmações coletadas durante a entrevista com o agente de melhoria da Montadora C:

a) A capacitação ajudou alguns agentes a acreditar que a aplicação da metodologia nos projetos de melhoria é importante, mesmo sob pressão de tempo.

b) Um processo objetivo de seleção de projetos deveria ser adotado, senão o agente fica a mercê de realizar projetos que consideram o interesse da chefia mas sem representatividade para o negócio.

c) É muito importante estabelecer um processo de compilação, acesso e utilização de projetos prévios, para ganhar tempo com análise e soluções de problemas similires.

d) Sem um sistema de padronização com sinalização clara das características especiais e um processo de validação das alterações de processo, os projetos de melhoria podem perder sua eficácia inicial. 
e) A alta direção deve conhecer e exigir a aplicação de metodologia para realização de projetos de melhoria.

f) Se a coordenação de melhoria tivesse acesso a informações sobre novas tecnologias, os projetos poderiam ser mais valorizados e as soluções poderiam também incluir inovações de processo.

g) A seleção de profissionais deveria ser condicionada a uma atitude favorável a melhoria contínua, ou no mínimo desenvolvê-la como parte do processo de capacitação.

h) O processo de capacitação deveria ser realista no sentido de mensurar que grau de lacuna atitudinal em relação a melhoria contínua é possível transformar com o processo de capacitação e que agentes possuem um grau de atitude tão desfavorável que nem deveriam ser selecionados como agentes internos de melhoria.

i) Um líder que opera num quadro enxuto de indiretos deveria ter apoio de uma área de tecnologia para implantar projetos de melhoria e inovação.

j) O processo de capacitação desenvolveu a capacidade analítica dos agentes internos, que mesmo sem praticar no dia a dia, afeta sua análise de dados e tomada de decisão.

5.3.4) Principais achados a partir da análise de projetos da Montadora C

Devido a confidencialidade das informações, os projetos de melhoria e demais documentos do programa de melhoria não foram liberados para cópia ou fotografia, portanto as constatações aqui são produto de anotações realizadas pelo pesquisador. A Ilustração 7 apresenta, de forma gráfica, os resultados dos projetos de melhoria analisados.

Ilustração 7 - Acompanhamento de Projetos na Montadora C 


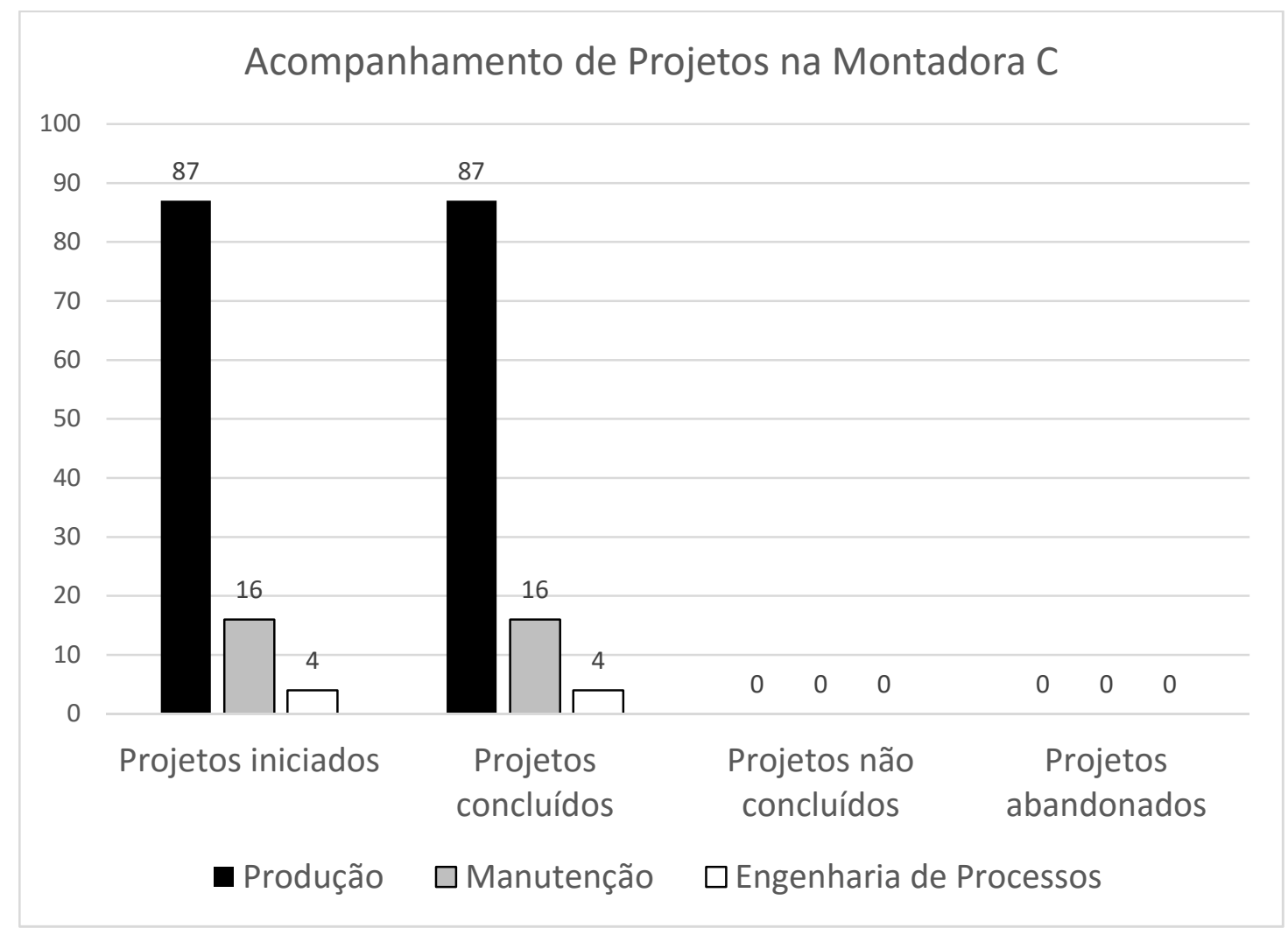

Fonte: elaborado pelo autor.

O sumário da análise dos projetos de melhoria na Montadora C está descrito no Quadro 20.1.

O sumário da análise de outras fontes de evidência coletadas na Montadora C está descrito no

Quadro 20.2.

Quadro 20.1 - Análise de projetos realizados na Montadora C.

\begin{tabular}{|l|l|}
\hline $\begin{array}{l}\text { Documento e tipo de } \\
\text { informação coletada }\end{array}$ & $\begin{array}{l}\text { Sumário dos principais achados após análise do(s) } \\
\text { documento(s) }\end{array}$ \\
\hline $\begin{array}{l}\text { Planilha de controle de } \\
\text { projetos - modelo contido no } \\
\text { Apêndice 7: Listagem com } \\
\text { todos os projetos de melhoria } \\
\text { iniciados incluindo: os nomes } \\
\text { dos agentes de melhoria, } \\
\text { gestores e time, o título e } \\
\text { metas do projeto e a situação } \\
\text { anderes de melhoria iniciados: 87 projetos liderados } \\
\text { mantenção e 4 projetos ligados à uma área de suporte a } \\
\text { produçáo denominada engenharia de processos. O programa } \\
\text { foi amplamente expandido para todas as oficinas da área de } \\
\text { produção da montadora e focou, essencialmente e capacitar } \\
\text { a liderança de produção na metodologia de realização de } \\
\text { projetos. Os projetos foram selecionados com a participação } \\
\text { ativa do diretor de planta que usava uma análise de } \\
\text { viabilidade para designar o projeto ao agente. Nesta análise } \\
\text { era considerada o grau de dificuldade de identificar } \\
\text { soluções, e, portanto, sempre que possível procurava-se }\end{array}$ \\
\hline
\end{tabular}




\begin{tabular}{|c|c|}
\hline & $\begin{array}{l}\text { selecionar projetos que tinham similaridade com soluções já } \\
\text { implantadas. }\end{array}$ \\
\hline 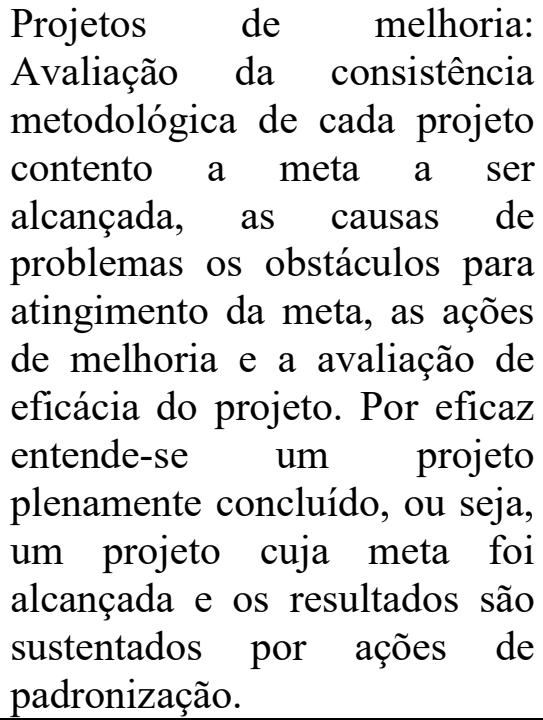 & $\begin{array}{l}\text { Todos os projetos foram plenamente concluídos. O diretor } \\
\text { de planta determinou que toda a liderança de manufatura } \\
\text { deveria ser agente de melhoria contínua e realizou análises } \\
\text { críticas de projetos em atraso semanalmente durante toda a } \\
\text { duração do programa de capacitação. Projetos que tiveram } \\
\text { atrasos, mas conseguiram ser concluídos plenamente no } \\
\text { prazo previsto contaram com as seguintes condições de } \\
\text { recuperação: a cobrança por explicações e plano de } \\
\text { recuperação do gestor pelo diretor de planta para alegações } \\
\text { do agente "não tive tempo ou não depende de mim" e a não } \\
\text { aceitação, por parte do diretor, de soluções do tipo "treinar } \\
\text { operador" para projetos ligados a erros ou desatenção } \\
\text { humana. }\end{array}$ \\
\hline $\begin{array}{l}\text { Planilha de acompanhamento } \\
\text { de projetos - modelo contido } \\
\text { no Apêndice } 7 \text { : avaliação da } \\
\text { participação dos gestores }\end{array}$ & $\begin{array}{l}\text { Assim como na Montadora A, foram realizadas } 6 \text { visitas de } \\
\text { acompanhamento de projeto, espaçadas de } 3 \text { a } 4 \text { semanas } \\
\text { entre si. Apenas } 6 \text { projetos, todos na área de manutenção, } \\
\text { não contaram com a participação dos gestores nas reuniões } \\
\text { de acompanhamento. Os gestores de produção não só } \\
\text { apoiavam, mas cobravam mais robustez nas ações, pois os } \\
\text { projetos tinham um significado prático na área e eles } \\
\text { conheciam sobre o processo a ser melhorado. }\end{array}$ \\
\hline $\begin{array}{l}\text { Planilha de acompanhamento } \\
\text { de projetos: avaliação da } \\
\text { participação das agentes }\end{array}$ & $\begin{array}{l}\text { Em } 17 \text { projetos sem a participação dos gestores os agentes } \\
\text { foram bem-sucedidos. Como os projetos tinham sido } \\
\text { selecionados pelo diretor de planta, um apoio formal da alta } \\
\text { direção esteve presente desde o início, viabilizando a } \\
\text { desobstrução de barreiras departamentais. Vale a pena } \\
\text { ressaltar também, que o fato dos agentes serem líderes ou } \\
\text { supervisores de produção e realizarem projetos ligados aos } \\
\text { seus processos produtivos, a questão da autonomia para } \\
\text { testar ideias e alterar o processo foi muito facilitada. }\end{array}$ \\
\hline
\end{tabular}

Fonte: elaborado pelo autor.

Quadro 20.2 - Análise de outras fontes de evidência observadas na Montadora C.

\begin{tabular}{|l|l|}
\hline Fonte de evidência & Sumário dos principais achados e conclusões \\
\hline Apresentação & $\begin{array}{l}\text { O programa de melhoria era corporativo e contava com o mesmo } \\
\text { propósito da Montadora A: “criação de uma cultura de melhoria } \\
\text { gentínua através da abertura de projetos de melhoria de forma } \\
\text { programa de }\end{array}$ \\
$\begin{array}{l}\text { sistemática e contínua. " Confirma-se também para a Montadora C a } \\
\text { expectativa de formar profissionais capazes de realizar projetos de } \\
\text { melhoria de forma contínua. }\end{array}$ \\
\hline
\end{tabular}




\begin{tabular}{|l|l|}
\hline $\begin{array}{l}\text { Atas de reunião } \\
\text { para seleção de } \\
\text { projeto }\end{array}$ & $\begin{array}{l}\text { Assim como na Montadora A, foram realizadas reuniões de } \\
\text { confirmação de projeto a ser conduzido por cada agente de melhoria. A } \\
\text { grande diferença é que os projetos eram selecionados pela alta direção e } \\
\text { não pelo gestor direto do agente de melhoria. }\end{array}$ \\
\hline Planilha de controle & $\begin{array}{l}\text { Durante o ano de 2015 e primeiro semestre de 2016, os agentes internos } \\
\text { capacitados realizaram 44 projetos de melhoria. Foram projetos ligados } \\
\text { a solução de problemas crônicos de qualidade e de eficiência produtiva. } \\
\text { de projetos não } \\
\text { ligados ao } \\
\text { treinamento inicial de 2016 o diretor de planta saiu do grupo automotivo. No seu } \\
\text { lugar entrou um novo diretor que não deu seguimento ao programa de } \\
\text { capacitação ou ao estímulo a abertura de projetos de melhoria com uso } \\
\text { de metodologia estruturada. }\end{array}$ \\
\hline Projetos de & $\begin{array}{l}\text { Alguns agentes continuaram a abrir novos projetos, mesmo após o } \\
\text { término da estrutura formal de gerenciamento do programa de } \\
\text { melhoria. Na montadora C, assim como na montadora A, também se } \\
\text { observa a abertura de novos projetos por profissionais que acreditam no } \\
\text { uso de metodologia para obtenção de melhoria sustentável ao longo do } \\
\text { tempo. Novamente, ressalta-se aqui a importância do aspecto de } \\
\text { agência humana. }\end{array}$ \\
controlados &
\end{tabular}

Fonte: elaborado pelo autor.

Considerando as informações levantadas nas entrevistas, a análise do resultado dos projetos e demais documentos e observações diretas do pesquisador podemos concluir que na Montadora $\mathrm{C}$ não ocorreu uma transformação efetiva dos profissionais treinados em agentes internos de melhoria.

\subsection{Comparação dos resultados entre as montadoras}

O quadro 21 apresenta a comparação de resultados dos projetos nas três montadoras estudadas.

Quadro 21 - Resultados dos projetos nas três montadoras.

\begin{tabular}{|c|c|c|c|}
\hline Aspectos avaliados & Montadora A & Montadora B & Montadora C \\
\hline Projetos iniciados & 103 & 200 & 107 \\
\hline Escopo dos projetos & $\begin{array}{l}\text { Projetos focavam } \\
\text { basicamente na } \\
\text { redução de defeitos e } \\
\text { foram conduzidos }\end{array}$ & $\begin{array}{lr}\text { Melhoria } & \mathrm{de} \\
\text { qualidade } & \mathrm{e} \\
\text { produtividade } & \\
\text { realizada } & \text { pelos }\end{array}$ & $\begin{array}{lr}\text { Melhoria } & \text { de } \\
\text { qualidade } & \mathrm{e} \\
\text { produtividade } & \\
\text { realizada } \quad \text { pelos }\end{array}$ \\
\hline
\end{tabular}




\begin{tabular}{|c|c|c|c|}
\hline & $\begin{array}{l}\text { por profissionais da } \\
\text { área da qualidade. }\end{array}$ & líderes de produção. & líderes de produção \\
\hline Projetos concluídos & 55 & 180 & 107 \\
\hline $\begin{array}{lr}\text { Abertura } & \text { de } \\
\text { projetos } & \text { pelos } \\
\text { agentes, } & \text { após a } \\
\text { capacitação inicial. }\end{array}$ & $\begin{array}{l}\text { Abertura de } 21 \text { novos } \\
\text { projetos por apenas } \\
\text { alguns dos agentes, } \\
\text { de forma isolada e } \\
\text { até o término formal } \\
\text { do programa. }\end{array}$ & $\begin{array}{l}\text { Continuidade } \\
\text { abertura de novos } \\
\text { projetos de forma } \\
\text { contínua pelos } \\
\text { agentes internos, } 715 \\
\text { projetos no total. }\end{array}$ & $\begin{array}{l}\text { Abertura de } 44 \text { novos } \\
\text { projetos por apenas } \\
\text { alguns agentes, de } \\
\text { forma isolada e até a } \\
\text { mudança do diretor } \\
\text { de planta. }\end{array}$ \\
\hline
\end{tabular}

Fonte: elaborado pelo autor.

Os termos mais recorrentes nas entrevistas das montadoras $\mathrm{A}$ e $\mathrm{C}$ foram direção, gestor, chefia e afins nas entrevistas. Isto mostra a importância do papel da direção e dos gestores nestas montadoras, onde não há um modelo de maturidade para a melhoria contínua. Estes termos não tiveram tanta incidência na Montadora B.

$\mathrm{Na}$ Montadora B existe um modelo de excelência em operações com níveis progressivos de melhoria contínua que é adotado em escala global. Isto significa que os projetos de melhoria devem ser realizados sistematicamente para que a avaliação da empresa na escala de maturidade, que é um indicador da alta direção, demonstre um patamar de evolução a cada auditoria semestral. Desta forma, na Montadora B, a rotina de realizar projetos de melhoria não varia com as mudanças de gerência ou direção, pois sempre estão na pauta do dia-a-dia.

$\mathrm{Na}$ montadora $\mathrm{C}$ o diretor da planta realizou abertura e fechamento dos treinamentos $\mathrm{e}$ diálogos com os consultores internos. Ele ainda designou que todos os gerentes de produção fossem os padrinhos dos agentes internos, que ocupavam a função de líder e supervisão de produção de todas as unidades produtivas. Na montadora $\mathrm{C}$ observou-se um engajamento com os projetos muito elevado, com índice de conclusão de $100 \%$ de todos os projetos iniciados. Quando o diretor saiu da empresa o programa de melhoria entrou em colapso, de forma similar a outra empresa do grupo, a Montadora A.

Podemos considerar a transformação de profissionais, membros da organização, em agentes internos de melhoria contínua como efetiva, se, após o término da capacitação inicial, os 
profissionais treinados continuam conduzindo novos projetos de melhoria. Pode-se observar este fenômeno apenas na Montadora B. Nas montadoras A e C, pertencentes ao mesmo grupo, não ocorreu sistematicamente esta transformação esperada, embora os resultados dos projetos iniciais e engajamento gerencial tenha sido elevado no início na Montadora C.

\subsection{Análise e classificação da relevância das proposições teóricas}

\subsubsection{Confirmação das proposições teóricas}

Nos Quadros 22.1 a 22.16 são apresentados os resultados relativos as 16 proposições teóricas com o objetivo de classificar seu grau de aderência com os resultados da pesquisa e observações em campo. A classificação das proposições teóricas entre os eixos conceituais institucionalização e agência humana, conforme apontado anteriormente no Quadro 16, aparece entre parêntesis ao lado da descrição de cada proposição.

Na coluna relatos estão referenciadas as declarações do coordenador, gestor e agentes de cada montadora, descritas nos itens 5.1 a 5.3 que tem algum tipo de relação com as proposições, não necessariamente direta ou forte, mas que pode ajudar na análise da relevância da proposição quando associada as fontes de evidência objetivas. Por exemplo, o Quadro 22.1 apresenta como relatos relacionados à proposição P1 as declarações descritas no item 5.1.1 letras g e h., oriundas da entrevista com o coordenador de melhoria da Montadora A.

Na coluna fontes objetivas estão sumarizadas as análises dos artefatos observados pelo pesquisador que confirmam ou não a proposição em cada montadora. Estes artefatos incluem: atas de reunião para seleção de projetos, avaliação da consistência metodológica em cada fase de cada projeto de melhoria, avaliação da capacidade de comunicação e das habilidades interpessoais para conduzir o projeto, quadros de gestão a vista disponíveis nas áreas, relatórios de acompanhamento de projetos e, no caso da Montadora B, resultados dos exames finais de conhecimento nas ferramentas de melhoria. Importante ressaltar que estas evidências foram possíveis devido ao fato do pesquisador continuar em contato com as montadoras com a prestação de demais serviços de consultoria após o término do processo de capacitação. 
Quadro 22.1 - Análise e classificação da relevância da proposição teórica P1 (Institucionalização).

P1: A transformação de profissionais, membros da organização, em agentes internos de melhoria deve ser vista como uma ação estratégica da alta direção.

\begin{tabular}{|c|c|c|c|c|c|c|}
\hline \multirow[t]{2}{*}{ Entrevistado } & \multicolumn{2}{|c|}{ Montadora A } & \multicolumn{2}{|c|}{ Montadora B } & \multicolumn{2}{|c|}{ Montadora C } \\
\hline & Entrevistas & Fontes objetivas & Entrevistas & Fontes objetivas & Entrevistas & Fontes objetivas \\
\hline Coordenador & 5.1.1: g, h. & \multirow{3}{*}{$\begin{array}{l}\text { O programa } \\
\text { ficou restrito a } \\
\text { área da } \\
\text { Qualidade e } \\
\text { acabou } \\
\text { oficialmente, } \\
\text { daí os relatos } \\
\text { dos gestores } \\
\text { sobre a } \\
\text { importância de } \\
\text { apoio da alta } \\
\text { direção. }\end{array}$} & 5.2.1:g. & \multirow{3}{*}{$\begin{array}{l}\text { Implantação de } \\
\text { pilar em quadro } \\
\text { de gestão a vista } \\
\text { é acompanhada } \\
\text { pelo líder de } \\
\text { pilar e pelo } \\
\text { diretor de } \\
\text { planta. } \\
\text { Avaliações do } \\
\text { nível de } \\
\text { maturidade do } \\
\text { programa são } \\
\text { comparadas } \\
\text { globalmente e é } \\
\text { usada como } \\
\text { indicador de } \\
\text { desempenho do } \\
\text { diretor de } \\
\text { planta. }\end{array}$} & $\begin{array}{l}\text { 5.3.1: a, c, e, f, } \\
\text { k. }\end{array}$ & \multirow{3}{*}{$\begin{array}{l}\text { Indicador de } \\
\text { status de projeto } \\
\text { acompanhado } \\
\text { semanalmente } \\
\text { pelo diretor de } \\
\text { planta. } \\
\text { Cobrança de } \\
\text { plano de ação } \\
\text { do gestor } \\
\text { quando projetos } \\
\text { tem avaliação } \\
\text { deficiente pela } \\
\text { consultoria. }\end{array}$} \\
\hline Gestor & $\begin{array}{l}\text { 5.1.2: b, d, e, } \\
\text { g, o, s. }\end{array}$ & & 5.2.2: c. & & $\begin{array}{l}\text { 5.1.2: b, d, e, g, } \\
\text { o, s. }\end{array}$ & \\
\hline Agente & $\begin{array}{l}\text { 5.1.3-A1: d, } \\
\text { e, g, h, j. } \\
\text { 5.1.3-A3: c. }\end{array}$ & & $\begin{array}{l}5.2 .3-\mathrm{A} 1: \mathrm{c} . \\
5.2 .3-\mathrm{A} 2: \mathrm{b}\end{array}$ & & 5.3.3: e. & \\
\hline Aderência & \multicolumn{2}{|c|}{$\begin{array}{l}14 \text { afirmações oriundas das } \\
\text { entrevistas e as fontes objetivas } \\
\text { comprovam a alta aderência da } \\
\text { proposição na Montadora A. }\end{array}$} & \multicolumn{2}{|c|}{$\begin{array}{l}4 \text { afirmações oriundas das } \\
\text { entrevistas e as fontes objetivas } \\
\text { comprovam a aderência moderada } \\
\text { da proposição na Montadora B. }\end{array}$} & \multicolumn{2}{|c|}{$\begin{array}{l}12 \text { afirmações oriundas das } \\
\text { entrevistas e as fontes objetivas } \\
\text { comprovam a alta aderência da } \\
\text { proposição na Montadora C. }\end{array}$} \\
\hline
\end{tabular}

Fonte: elaborado pelo autor. 
Quadro 22.2 - Análise e classificação da relevância da proposição teórica P2 (Institucionalização).

P2: A transformação de profissionais, membros da organização, em agentes internos de melhoria requer um investimento de tempo e participação dos gestores no apoio a realização de projetos de melhoria.

\begin{tabular}{|c|c|c|c|c|c|c|}
\hline \multirow[t]{2}{*}{ Entrevistado } & \multicolumn{2}{|c|}{ Montadora A } & \multicolumn{2}{|c|}{ Montadora B } & \multicolumn{2}{|c|}{ Montadora $\mathrm{C}$} \\
\hline & Entrevistas & Fontes objetivas & Entrevistas & Fontes objetivas & Entrevistas & Fontes objetivas \\
\hline Coordenador & $\begin{array}{l}\text { 5.1.1: h, k, 1, } \\
\text { n. }\end{array}$ & \multirow{3}{*}{$\begin{array}{l}\text { Os agentes } \\
\text { internos com } \\
\text { melhor } \\
\text { desempenho } \\
\text { nos projetos } \\
\text { concentraram- } \\
\text { se numa área } \\
\text { onde o gestor } \\
\text { apoiava e } \\
\text { participava } \\
\text { ativamente dos } \\
\text { projetos de } \\
\text { melhoria. }\end{array}$} & 5.2.1: e, g. & \multirow{3}{*}{$\begin{array}{l}\text { Alguns gestores } \\
\text { participavam } \\
\text { ativamente da } \\
\text { apresentação } \\
\text { dos projetos. } \\
\text { Nesta } \\
\text { montadora, o } \\
\text { RH tinha um } \\
\text { papel muito } \\
\text { forte de } \\
\text { cobrança junto } \\
\text { aos gestores } \\
\text { sobre a } \\
\text { implantação de } \\
\text { projetos. }\end{array}$} & 5.3.1: h. & \multirow{3}{*}{$\begin{array}{l}\text { Os gestores que } \\
\text { participavam das } \\
\text { reuniões de } \\
\text { acompanhamento } \\
\text { de projetos } \\
\text { dispunham } \\
\text { maiores recursos } \\
\text { e ao mesmo } \\
\text { tempo cobravam } \\
\text { mais rigor nas } \\
\text { análises e } \\
\text { soluções } \\
\text { propostas. }\end{array}$} \\
\hline Gestor & $\begin{array}{l}\text { 5.1.2: c, d, g, } \\
\mathrm{h}, \mathrm{j}, \mathrm{n}, \mathrm{p} .\end{array}$ & & 5.2.2: b, c, e. & & $\begin{array}{l}\text { 5.1.2: c, d, g, h, } \\
\text { j, n, p. }\end{array}$ & \\
\hline Agente & $\begin{array}{l}\text { 5.1.3-A2: c. } \\
\text { 5.1.3-A3: e. }\end{array}$ & & $\begin{array}{l}\text { 5.2.3-A2: c. } \\
5.2 .3-\mathrm{A} 3: \mathrm{b} .\end{array}$ & & 5.3.3: b. & \\
\hline Aderência & \multicolumn{2}{|c|}{$\begin{array}{l}13 \text { afirmações oriundas das } \\
\text { entrevistas e as fontes objetivas } \\
\text { comprovam a alta aderência da } \\
\text { proposição na Montadora A. }\end{array}$} & \multicolumn{2}{|c|}{$\begin{array}{l}7 \text { afirmações oriundas das } \\
\text { entrevistas e as fontes objetivas } \\
\text { comprovam a alta aderência da } \\
\text { proposição na Montadora B. }\end{array}$} & \multicolumn{2}{|c|}{$\begin{array}{l}9 \text { afirmações oriundas das } \\
\text { entrevistas e as fontes objetivas } \\
\text { comprovam a alta aderência da } \\
\text { proposição na Montadora C. }\end{array}$} \\
\hline
\end{tabular}

Fonte: elaborado pelo autor. 
Quadro 22.3 - Análise e classificação da relevância da proposição teórica P3 (Agência humana).

P3: Os profissionais selecionados para se tornarem agentes internos de melhoria devem demonstrar atitude favorável a melhoria e perceber-se capaz de realizar projetos de melhoria.

\begin{tabular}{|c|c|c|c|c|c|c|}
\hline \multirow[t]{2}{*}{ Entrevistado } & \multicolumn{2}{|c|}{ Montadora A } & \multicolumn{2}{|c|}{ Montadora B } & \multicolumn{2}{|c|}{ Montadora $\mathrm{C}$} \\
\hline & Entrevistas & Fontes objetivas & Entrevistas & Fontes objetivas & Entrevistas & Fontes objetivas \\
\hline Coordenador & $\begin{array}{l}\text { 5.1.1: c, d,e, } \\
\text { j, m, n, o, p, } \\
\text { r. }\end{array}$ & \multirow{3}{*}{$\begin{array}{l}\text { Mesmo diante } \\
\text { do término } \\
\text { formal do } \\
\text { programa, } \\
\text { agentes da área } \\
\text { de garantia } \\
\text { continuam a } \\
\text { conduzir } \\
\text { projetos por } \\
\text { valorizarem o } \\
\text { uso da } \\
\text { metodologia na } \\
\text { solução dos } \\
\text { problemas de } \\
\text { seu dia-a-dia. }\end{array}$} & $\begin{array}{l}\text { 5.2.1: b, c, f, k, } \\
\text { m. }\end{array}$ & \multirow{3}{*}{$\begin{array}{l}\text { Apesar da forte } \\
\text { estrutura de } \\
\text { apoio e } \\
\text { cobrança para } \\
\text { novos projetos } \\
\text { nem todos os } \\
\text { agentes } \\
\text { treinados } \\
\text { continuam a } \\
\text { conduzir novos } \\
\text { projetos, o que } \\
\text { leva a } \\
\text { confirmação da } \\
\text { importância da } \\
\text { atitude } \\
\text { favorável. }\end{array}$} & 5.3.1: g, j. & \multirow{3}{*}{$\begin{array}{l}\text { Semelhante ao } \\
\text { ocorrido na } \\
\text { montadora A, } \\
\text { apesar do } \\
\text { término formal } \\
\text { do programa, } \\
\text { alguns agentes } \\
\text { continuam } \\
\text { usando a } \\
\text { metodologia } \\
\text { para conduzir } \\
\text { novos projetos } \\
\text { de melhoria. }\end{array}$} \\
\hline Gestor & $\begin{array}{l}\text { 5.1.2: f, k, } 1 \text {, } \\
\text { m, q. }\end{array}$ & & $\begin{array}{l}\text { Nenhuma } \\
\text { afirmação. }\end{array}$ & & $\begin{array}{l}5.1 .2: \mathrm{f}, \mathrm{k}, \mathrm{l}, \mathrm{m} \text {, } \\
\text { q. }\end{array}$ & \\
\hline Agente & $\begin{array}{l}\text { 5.1.3-A1: d, } \\
\text { f, i. } \\
\text { 5.1.3-A2: b, } \\
\text { h. } \\
\text { 5.1.3-A3: a, } \\
\text { b, e, g. }\end{array}$ & & $\begin{array}{l}\text { 5.2.3-A2: d. } \\
\text { 5.2.3-A3: a. } \\
\text { 5.2.3-A4: a. }\end{array}$ & & 5.3.3: a, g, h, j. & \\
\hline Aderência & \multicolumn{2}{|c|}{$\begin{array}{l}23 \text { afirmações oriundas das } \\
\text { entrevistas e as fontes objetivas } \\
\text { comprovam a alta aderência da } \\
\text { proposição na Montadora A. }\end{array}$} & \multicolumn{2}{|c|}{$\begin{array}{l}\text { Embora existam } 8 \text { afirmações e } \\
\text { fontes objetivas, a ausência de } \\
\text { relatos pelo gestor torna a } \\
\text { aderência a proposição moderada } \\
\text { na Montadora B. }\end{array}$} & \multicolumn{2}{|c|}{$\begin{array}{l}10 \text { afirmações oriundas das } \\
\text { entrevistas e as fontes objetivas } \\
\text { comprovam a alta aderência da } \\
\text { proposição na Montadora C. }\end{array}$} \\
\hline
\end{tabular}

Fonte: elaborado pelo autor. 
Quadro 22.4 - Análise e classificação da relevância da proposição teórica P4 (Agência humana).

P4: Os profissionais selecionados para se tornarem agentes internos de melhoria devem conhecer as metas organizacionais e estarem no nível organizacional adequado com a maturidade do programa (quanto menos madura a melhoria contínua, maior o nível hierárquico necessário).

\begin{tabular}{|c|c|c|c|c|c|c|}
\hline \multirow[t]{2}{*}{ Entrevistado } & \multicolumn{2}{|c|}{ Montadora A } & \multicolumn{2}{|c|}{ Montadora B } & \multicolumn{2}{|c|}{ Montadora $\mathrm{C}$} \\
\hline & Entrevistas & Fontes objetivas & Entrevistas & Fontes objetivas & Entrevistas & Fontes objetivas \\
\hline Coordenador & 5.1.1: b, e, f. & \multirow{3}{*}{$\begin{array}{l}\text { Mesmo } \\
\text { conhecendo as } \\
\text { metas } \\
\text { organizacionais } \\
\text { alguns agentes } \\
\text { não conduziram } \\
\text { seus projetos. } \\
\text { Algumas } \\
\text { pessoas } \\
\text { treinadas da } \\
\text { área de garantia, } \\
\text { mesmo sem ter } \\
\text { cargo de chefia, } \\
\text { continuam a } \\
\text { realizar novos } \\
\text { projetos. }\end{array}$} & 5.2.1: b, d. & \multirow{3}{*}{$\begin{array}{l}\text { Os líderes de } \\
\text { produção } \\
\text { tiveram a } \\
\text { facilidade de } \\
\text { conduzir } \\
\text { projetos que } \\
\text { estavam } \\
\text { diretamente } \\
\text { ligados a sua } \\
\text { área, o que } \\
\text { favoreceu ao } \\
\text { seu } \\
\text { engajamento. }\end{array}$} & 5.3.1: j, k & \multirow{3}{*}{$\begin{array}{l}\text { A valorização } \\
\text { do líder de } \\
\text { produção como } \\
\text { agente de } \\
\text { melhoria é uma } \\
\text { confirmação da } \\
\text { importância do } \\
\text { nível } \\
\text { hierárquico, } \\
\text { porém } \\
\text { observou-se } \\
\text { diversos agentes } \\
\text { não líderes que } \\
\text { continuam a } \\
\text { realizar } \\
\text { projetos. }\end{array}$} \\
\hline Gestor & 5.1.2: f. & & $\begin{array}{l}\text { Nenhuma } \\
\text { afirmação. }\end{array}$ & & 5.1.2: $\mathrm{f}$. & \\
\hline Agente & $\begin{array}{l}\text { 5.1.3-A1:h. } \\
\text { 5.1.3-A2: e, } \\
\text { h. }\end{array}$ & & 5.2.3-A2: d. & & 5.3.3: b, i. & \\
\hline Aderência & \multicolumn{2}{|c|}{$\begin{array}{l}7 \text { afirmações oriundas das } \\
\text { entrevistas e as fontes objetivas } \\
\text { comprovam a aderência } \\
\text { moderada da proposição na } \\
\text { Montadora A. }\end{array}$} & \multicolumn{2}{|c|}{$\begin{array}{l}3 \text { afirmações oriundas das } \\
\text { entrevistas e as fontes objetivas } \\
\text { comprovam a aderência moderada } \\
\text { da proposição na Montadora B. }\end{array}$} & \multicolumn{2}{|c|}{$\begin{array}{l}5 \text { afirmações oriundas das } \\
\text { entrevistas e as fontes objetivas } \\
\text { comprovam a alta aderência da } \\
\text { proposição na Montadora C. }\end{array}$} \\
\hline
\end{tabular}

Fonte: elaborado pelo autor. 
Quadro 22.5 - Análise e classificação da relevância da proposição teórica P5 (Institucionalização).

P5: Deve-se desenvolver a habilidade do agente interno de melhoria em aplicar na prática uma metodologia e ferramentas de solução de problemas de acordo com o tipo de projeto e dos processos organizacionais.

\begin{tabular}{|c|c|c|c|c|c|c|}
\hline \multirow[t]{2}{*}{ Entrevistado } & \multicolumn{2}{|c|}{ Montadora A } & \multicolumn{2}{|c|}{ Montadora B } & \multicolumn{2}{|c|}{ Montadora $\mathrm{C}$} \\
\hline & Entrevistas & Fontes objetivas & Entrevistas & Fontes objetivas & Entrevistas & Fontes objetivas \\
\hline Coordenador & $\begin{array}{l}\text { 5.1.1: } \mathrm{a}, \mathrm{b}, \mathrm{d}, \\
\mathrm{e}, \mathrm{f} .\end{array}$ & \multirow{3}{*}{$\begin{array}{l}\text { Em projetos } \\
\text { cuja análise de } \\
\text { causa raiz } \\
\text { expunham a } \\
\text { fragilidade de } \\
\text { uma área, a } \\
\text { questão política } \\
\text { passa a atuar } \\
\text { como uma } \\
\text { barreira para } \\
\text { aplicar } \\
\text { ferramentas e } \\
\text { resolver } \\
\text { definitivamente } \\
\text { o problema, fato } \\
\text { não explicado } \\
\text { pela proposição. }\end{array}$} & 5.2.1: f, h. & \multirow{3}{*}{$\begin{array}{l}\text { As notas de } \\
\text { avaliação de } \\
\text { consistência de } \\
\text { projetos } \\
\text { apontam para } \\
\text { menor robustez } \\
\text { nos projetos da } \\
\text { área de } \\
\text { montagem e } \\
\text { recorrentes } \\
\text { restaurações de } \\
\text { padrões em } \\
\text { situações de } \\
\text { fragilidades } \\
\text { tecnológicas do } \\
\text { processo } \\
\text { produtivo. }\end{array}$} & $\begin{array}{l}\text { Nenhuma } \\
\text { afirmação. }\end{array}$ & \multirow{3}{*}{$\begin{array}{l}\text { Este papel é } \\
\text { realizado em } \\
\text { parte pela } \\
\text { consultoria } \\
\text { externa ao } \\
\text { acompanhar } \\
\text { projetos e } \\
\text { indicar as } \\
\text { ferramentas } \\
\text { apropriadas, } \\
\text { fato não } \\
\text { explicado pela } \\
\text { proposição. }\end{array}$} \\
\hline Gestor & 5.1.2: $1, \mathrm{r}$. & & 5.2.2: a. & & 5.1.2: $1, \mathrm{r}$. & \\
\hline Agente & $\begin{array}{l}\text { 5.1.3-A1: b, } \\
\text { c, f. } \\
\text { 5.1.3-A2: a. } \\
\text { 5.1.3-A3: b, } \\
\text { f. }\end{array}$ & & $\begin{array}{l}\text { 5.2.3-A1: a. } \\
\text { 5.2.3-A2: a. } \\
\text { 5.2.3-A3: a. } \\
\text { 5.2.3-A4: a. }\end{array}$ & & 5.3.3: a,j. & \\
\hline Aderência & \multicolumn{2}{|c|}{$\begin{array}{l}\text { As } 13 \text { afirmações não são } \\
\text { relacionadas exclusivamente a } \\
\text { capacitação. As fontes objetivas } \\
\text { comprovam a aderência } \\
\text { moderada da proposição na } \\
\text { Montadora A. }\end{array}$} & \multicolumn{2}{|c|}{$\begin{array}{l}7 \text { afirmações oriundas das } \\
\text { entrevistas e as fontes objetivas } \\
\text { comprovam a aderência moderada } \\
\text { da proposição na Montadora B. }\end{array}$} & \multicolumn{2}{|c|}{$\begin{array}{l}4 \text { afirmações oriundas das } \\
\text { entrevistas e as fontes objetivas } \\
\text { comprovam a aderência moderada } \\
\text { da proposição na Montadora C. }\end{array}$} \\
\hline
\end{tabular}

Fonte: elaborado pelo autor. 
Quadro 22.6 - Análise e classificação da relevância da proposição teórica P6 (Agência humana).

P6: Deve-se desenvolver a habilidade do agente interno de melhoria em gerenciamento de tempo, gerenciamento de conflito, delegação, aceitação a mudança e pensamento sistêmico.

\begin{tabular}{|c|c|c|c|c|c|c|}
\hline \multirow[t]{2}{*}{ Entrevistado } & \multicolumn{2}{|c|}{ Montadora A } & \multicolumn{2}{|c|}{ Montadora B } & \multicolumn{2}{|c|}{ Montadora $\mathrm{C}$} \\
\hline & Entrevistas & Fontes objetivas & Entrevistas & Fontes objetivas & Entrevistas & Fontes objetivas \\
\hline Coordenador & $\begin{array}{l}\text { 5.1.1: c, d, e, } \\
\text { f, i, j, m, n, } \\
\text { o, r. }\end{array}$ & \multirow{3}{*}{$\begin{array}{l}\text { Durante a } \\
\text { realização dos } \\
\text { projetos, era } \\
\text { nítido que boa } \\
\text { parte dos } \\
\text { profissionais } \\
\text { não acreditava } \\
\text { na metodologia } \\
\text { e fazia porque o } \\
\text { chefe tinha } \\
\text { indicado. A } \\
\text { consultoria } \\
\text { falhou ao não } \\
\text { abordar a } \\
\text { mudança } \\
\text { atitudinal. }\end{array}$} & 5.2.1: d, f, m. & \multirow{3}{*}{$\begin{array}{l}\text { Os agentes que } \\
\text { demonstraram } \\
\text { melhor } \\
\text { desempenho nas } \\
\text { avaliações de } \\
\text { projeto e exame } \\
\text { final foram } \\
\text { aqueles } \\
\text { conseguiram } \\
\text { delegar a rotina } \\
\text { da área durante } \\
\text { a imersão de } \\
\text { capacitação. } \\
\text { Observa-se um } \\
\text { elevado número } \\
\text { de projetos } \\
\text { ligados apenas a } \\
\text { restauração de } \\
\text { padrões. }\end{array}$} & 5.3.1: g, j. & \multirow{3}{*}{$\begin{array}{l}\text { Nos projetos } \\
\text { onde houve } \\
\text { necessidade de } \\
\text { envolvimento } \\
\text { de múltiplas } \\
\text { áreas, as } \\
\text { habilidades de } \\
\text { gerenciamento } \\
\text { de conflito e } \\
\text { pensamento } \\
\text { sistêmico foram } \\
\text { fundamentais. } \\
\text { "Não tive } \\
\text { tempo" ou "Não } \\
\text { depende de } \\
\text { mim" eram } \\
\text { frases comuns } \\
\text { nos projetos } \\
\text { atrasados. }\end{array}$} \\
\hline Gestor & 5.1.2: f, k, q. & & $\begin{array}{l}\text { Nenhuma } \\
\text { informação. }\end{array}$ & & 5.1.2: f, k, q. & \\
\hline Agente & $\begin{array}{l}\text { 5.1.3-A1: d, } \\
\text { i. } \\
\text { 5.1.3-A2: b, } \\
\text { h. } \\
\text { 5.1.3-A3: a, } \\
\text { g. }\end{array}$ & & $\begin{array}{l}5.2 .3-\mathrm{A} 1: \mathrm{c} . \\
5.2 .3-\mathrm{A} 2: \mathrm{d} .\end{array}$ & & 5.3.3: h. & \\
\hline Aderência & \multicolumn{2}{|c|}{$\begin{array}{l}19 \text { afirmações oriundas das } \\
\text { entrevistas e as fontes objetivas } \\
\text { comprovam a alta aderência da } \\
\text { proposição na Montadora A. }\end{array}$} & \multicolumn{2}{|c|}{$\begin{array}{l}5 \text { afirmações oriundas das } \\
\text { entrevistas e as fontes objetivas } \\
\text { comprovam a aderência moderada } \\
\text { da proposição na Montadora B. }\end{array}$} & \multicolumn{2}{|c|}{$\begin{array}{l}6 \text { afirmações oriundas das } \\
\text { entrevistas e as fontes objetivas } \\
\text { comprovam a alta aderência da } \\
\text { proposição na Montadora C. }\end{array}$} \\
\hline
\end{tabular}

Fonte: elaborado pelo autor. 
Quadro 22.7 - Análise e classificação da relevância da proposição teórica P7 (Institucionalização).

P7: O coordenador de melhoria contínua deve ser escolhido cuidadosamente e ter dedicação de tempo integral na função.

\begin{tabular}{|c|c|c|c|c|c|c|}
\hline \multirow[t]{2}{*}{ Entrevistado } & \multicolumn{2}{|c|}{ Montadora A } & \multicolumn{2}{|c|}{ Montadora B } & \multicolumn{2}{|c|}{ Montadora C } \\
\hline & Entrevistas & $\begin{array}{c}\text { Fontes } \\
\text { objetivas }\end{array}$ & Entrevistas & Fontes objetivas & Entrevistas & Fontes objetivas \\
\hline Coordenador & 5.1.1: i, s. & \multirow{3}{*}{$\begin{array}{l}\text { O coordenador } \\
\text { tentava, mas } \\
\text { não preenchia a } \\
\text { expectativa dos } \\
\text { agentes quanto } \\
\text { a obtenção de } \\
\text { apoio político e } \\
\text { conhecimento } \\
\text { técnico, apenas } \\
\text { "aumentando" } \\
\text { o volume da } \\
\text { reclamação dos } \\
\text { agentes sobre a } \\
\text { falta de apoio } \\
\text { nos projetos. }\end{array}$} & 5.2.1: i. & \multirow{3}{*}{$\begin{array}{l}\text { Os chamados } \\
\text { coordenadores } \\
\text { de pilar na } \\
\text { realidade } \\
\text { desempenhavam } \\
\text { o papel de } \\
\text { especialista } \\
\text { metodológico } \\
\text { na planta. O } \\
\text { coordenador de } \\
\text { melhoria fazia } \\
\text { apenas trabalhos } \\
\text { administrativos, } \\
\text { como na } \\
\text { Montadora C. }\end{array}$} & $\begin{array}{l}\text { Nenhuma } \\
\text { informação. }\end{array}$ & \multirow{3}{*}{$\begin{array}{l}\text { O coordenador } \\
\text { acabava } \\
\text { desempenhando } \\
\text { um papel } \\
\text { restrito de } \\
\text { secretaria da } \\
\text { consultoria } \\
\text { externa e } \\
\text { geração do } \\
\text { indicador de } \\
\text { situação dos } \\
\text { projetos para } \\
\text { reportar ao } \\
\text { diretor de } \\
\text { planta. }\end{array}$} \\
\hline Gestor & 5.1.2: g. & & $\begin{array}{l}\text { Nenhuma } \\
\text { informação. }\end{array}$ & & 5.1.2: g. & \\
\hline Agente & $\begin{array}{l}5.1 .3-\mathrm{A} 1: \mathrm{c} . \\
5.1 .3-\mathrm{A} 3: \mathrm{d} .\end{array}$ & & 5.2.3-A2: c. & & 5.3.3: f. & \\
\hline Aderência & \multicolumn{2}{|c|}{$\begin{array}{l}5 \text { afirmações oriundas das } \\
\text { entrevistas e as fontes } \\
\text { objetivas demonstram a } \\
\text { ineficácia do papel de } \\
\text { coordenador e comprovam a } \\
\text { não aderência da proposição na } \\
\text { Montadora A. }\end{array}$} & \multicolumn{2}{|c|}{$\begin{array}{l}2 \text { afirmações oriundas das } \\
\text { entrevistas e as fontes objetivas } \\
\text { demonstram a ineficácia do } \\
\text { papel de coordenador e } \\
\text { comprovam a aderência } \\
\text { moderada da proposição na } \\
\text { Montadora B. }\end{array}$} & \multicolumn{2}{|c|}{$\begin{array}{l}2 \text { afirmações oriundas das } \\
\text { entrevistas e as fontes objetivas } \\
\text { demonstram a ineficácia do } \\
\text { papel de coordenador e } \\
\text { comprovam a aderência } \\
\text { moderada da proposição na } \\
\text { Montadora C. }\end{array}$} \\
\hline
\end{tabular}

Fonte: elaborado pelo autor. 
Quadro 22.8 - Análise e classificação da relevância da proposição teórica P8 (Institucionalização).

P8: O projeto deve ter objetivo mensurável, alinhado com a estratégia organizacional, de apuração de resultado não ambígua.

\begin{tabular}{|c|c|c|c|c|c|c|}
\hline \multirow[t]{2}{*}{ Entrevistado } & \multicolumn{2}{|c|}{ Montadora A } & \multicolumn{2}{|c|}{ Montadora B } & \multicolumn{2}{|c|}{ Montadora C } \\
\hline & Entrevistas & Fontes objetivas & Entrevistas & Fontes objetivas & Entrevistas & Fontes objetivas \\
\hline Coordenador & 5.1.1: p, q, u. & \multirow{3}{*}{$\begin{array}{l}\text { Os projetos que } \\
\text { mais } \\
\text { apresentaram } \\
\text { dificuldades } \\
\text { foram aqueles } \\
\text { em que o os } \\
\text { dados ou a } \\
\text { metodologia de } \\
\text { cálculo } \\
\text { indicador de } \\
\text { desempenho } \\
\text { não era } \\
\text { confiável. }\end{array}$} & 5.2.1: d, 1. & \multirow{3}{*}{$\begin{array}{l}\text { Integração entre } \\
\text { pilares é um } \\
\text { diferencial que } \\
\text { torna mais } \\
\text { sistêmica os } \\
\text { projetos na } \\
\text { Montadora B. } \\
\text { Melhorias } \\
\text { ligadas ao pilar } \\
\text { manutenção } \\
\text { deveriam } \\
\text { considerar os } \\
\text { pilares pessoal, } \\
\text { qualidade, meio } \\
\text { ambiente, } \\
\text { tornando as } \\
\text { ações mais } \\
\text { robustas e } \\
\text { sustentáveis. }\end{array}$} & $\begin{array}{l}\text { 5.3.1: b, c, d, i, } \\
\text { k. }\end{array}$ & \multirow{3}{*}{$\begin{array}{l}\text { Salvo mínimas } \\
\text { exceções, os } \\
\text { projetos } \\
\text { adotavam o } \\
\text { indicador de } \\
\text { desempenho da } \\
\text { área produtiva } \\
\text { do agente, } \\
\text { facilitando a } \\
\text { coleta de dados } \\
\text { e a } \\
\text { comprovação de } \\
\text { eficácias das } \\
\text { melhorias } \\
\text { implantadas. }\end{array}$} \\
\hline Gestor & 5.1.2: o. & & $\begin{array}{l}\text { Nenhuma } \\
\text { informação. }\end{array}$ & & 5.1.2: o. & \\
\hline Agente & $\begin{array}{l}\text { 5.1.3-A1: a, } \\
\text { h,j. } \\
\text { 5.1.3-A2: f. }\end{array}$ & & $\begin{array}{l}\text { Nenhuma } \\
\text { informação. }\end{array}$ & & 5.3.3: b. & \\
\hline Aderência & \multicolumn{2}{|c|}{$\begin{array}{l}8 \text { afirmações oriundas das } \\
\text { entrevistas e as fontes objetivas } \\
\text { comprovam a alta aderência da } \\
\text { proposição na Montadora A. }\end{array}$} & \multicolumn{2}{|c|}{$\begin{array}{l}2 \text { afirmações e as fontes objetivas } \\
\text { comprovam a aderência moderada } \\
\text { da proposição na Montadora B. }\end{array}$} & \multicolumn{2}{|c|}{$\begin{array}{l}7 \text { afirmações oriundas das } \\
\text { entrevistas e as fontes objetivas } \\
\text { comprovam a alta aderência da } \\
\text { proposição na Montadora C. }\end{array}$} \\
\hline
\end{tabular}

Fonte: elaborado pelo autor. 
Quadro 22.9 - Análise e classificação da relevância da proposição teórica P9 (Institucionalização).

P9: Deve ser estabelecido um processo de gestão do conhecimento, capaz de resgatar e utilizar o conhecimento gerado em projetos anteriores, que facilite a condução de novos projetos otimizando o estado futuro já alcançado em projetos anteriores.

\begin{tabular}{|c|c|c|c|c|c|c|}
\hline \multirow[t]{2}{*}{ Entrevistado } & \multicolumn{2}{|c|}{ Montadora A } & \multicolumn{2}{|c|}{ Montadora B } & \multicolumn{2}{|c|}{ Montadora C } \\
\hline & Entrevistas & Fontes objetivas & Entrevistas & Fontes objetivas & Entrevistas & Fontes objetivas \\
\hline Coordenador & $\begin{array}{l}\text { Nenhuma } \\
\text { informação. }\end{array}$ & \multirow{3}{*}{$\begin{array}{l}\text { Projetos com } \\
\text { melhorias } \\
\text { paliativas } \\
\text { podem alcançar } \\
\text { a meta, mas não } \\
\text { se sustentaram } \\
\text { após alguns } \\
\text { meses. Nestes } \\
\text { casos observou- } \\
\text { se uma grande } \\
\text { falha na etapa } \\
\text { final de } \\
\text { padronização do } \\
\text { conhecimento } \\
\text { gerado com o } \\
\text { projeto. }\end{array}$} & 5.2.1: d, g, 1. & \multirow{3}{*}{$\begin{array}{l}\text { A importância } \\
\text { da gestão do } \\
\text { conhecimento } \\
\text { aparece aqui } \\
\text { através dos } \\
\text { termos } \\
\text { integração com } \\
\text { os pilares, } \\
\text { implantação de } \\
\text { área modelo e } \\
\text { do modelo de } \\
\text { maturidade em } \\
\text { excelência das } \\
\text { operações. }\end{array}$} & $\begin{array}{l}\text { Nenhuma } \\
\text { informação. }\end{array}$ & \multirow{3}{*}{$\begin{array}{l}\text { Os projetos em } \\
\text { que a estratégia } \\
\text { de sua seleção } \\
\text { foi a extensão } \\
\text { de melhorias } \\
\text { implantadas } \\
\text { anteriormente } \\
\text { em outros } \\
\text { produtos e } \\
\text { processos foram } \\
\text { bem-sucedidos } \\
\text { e concluídos no } \\
\text { prazo. }\end{array}$} \\
\hline Gestor & 5.1.2: $\mathrm{f}, \mathrm{r}$. & & 5.2.2: $\mathrm{d}$ & & 5.1.2: f, r. & \\
\hline Agente & $\begin{array}{l}\text { 5.1.3-A2: b } \\
\text { 5.1.3-A3: b, } \\
\text { d. }\end{array}$ & & $\begin{array}{l}\text { Nenhuma } \\
\text { informação. }\end{array}$ & & 5.3.3: b, c. & \\
\hline Aderência & \multicolumn{2}{|c|}{$\begin{array}{l}5 \text { afirmações oriundas das } \\
\text { entrevistas e as fontes objetivas } \\
\text { comprovam a aderência } \\
\text { moderada da proposição na } \\
\text { Montadora A. }\end{array}$} & \multicolumn{2}{|c|}{$\begin{array}{l}4 \text { afirmações oriundas das } \\
\text { entrevistas e as fontes objetivas } \\
\text { comprovam a aderência moderada } \\
\text { da proposição na Montadora B. }\end{array}$} & \multicolumn{2}{|c|}{$\begin{array}{l}4 \text { afirmações oriundas das } \\
\text { entrevistas e as fontes objetivas } \\
\text { comprovam a aderência moderada } \\
\text { da proposição na Montadora C. }\end{array}$} \\
\hline
\end{tabular}

Fonte: elaborado pelo autor. 
Quadro 22.10 - Análise e classificação da relevância da proposição teórica P10 (Institucionalização).

P10: Deve estar implantada uma sistemática de seleção de projetos com critérios objetivos e uma função de coordenação de portfólio de projetos.

\begin{tabular}{|c|c|c|c|c|c|c|}
\hline \multirow[t]{2}{*}{ Entrevistado } & \multicolumn{2}{|c|}{ Montadora A } & \multicolumn{2}{|c|}{ Montadora B } & \multicolumn{2}{|c|}{ Montadora C } \\
\hline & Entrevistas & $\begin{array}{c}\text { Fontes } \\
\text { objetivas }\end{array}$ & Entrevistas & $\begin{array}{c}\text { Fontes } \\
\text { objetivas }\end{array}$ & Entrevistas & Fontes objetivas \\
\hline Coordenador & 5.1.1:a. & \multirow{3}{*}{$\begin{array}{l}\text { A consultoria } \\
\text { ajuda com a } \\
\text { visão de } \\
\text { viabilidade dos } \\
\text { projetos mesmo } \\
\text { antes de iniciar } \\
\text { a capacitação. } \\
\text { Boa seleção de } \\
\text { projetos } \\
\text { facilita, mas } \\
\text { não garante um } \\
\text { término bem } \\
\text { sucedido em } \\
\text { vários casos. }\end{array}$} & $\begin{array}{l}\text { Nenhuma } \\
\text { informação. }\end{array}$ & \multirow{3}{*}{$\begin{array}{l}\text { A seleção dos } \\
\text { projetos ficava } \\
\text { muito a cargo } \\
\text { do agente, } \\
\text { diferente das } \\
\text { montadoras A e } \\
\text { C, onde o } \\
\text { coordenador e } \\
\text { alguns gestores } \\
\text { foram mais } \\
\text { ativos nesta } \\
\text { etapa. }\end{array}$} & 5.3.1: e, j, k. & \multirow{3}{*}{$\begin{array}{l}\text { A coordenação do } \\
\text { portfólio de } \\
\text { projetos era feita } \\
\text { pelo coordenador. } \\
\text { Entretanto, assim } \\
\text { como na } \\
\text { Montadora A, ela } \\
\text { limitava-se a } \\
\text { registrar o projeto } \\
\text { numa lista e gerar } \\
\text { relatórios de } \\
\text { acompanhamento. } \\
\text { O Diretor validou } \\
\text { a escolha dos } \\
\text { projetos. }\end{array}$} \\
\hline Gestor & 5.1.2: i. & & $\begin{array}{l}\text { Nenhuma } \\
\text { informação. }\end{array}$ & & 5.1.2: i. & \\
\hline Agente & $\begin{array}{l}\text { 5.1.3-A1: b. } \\
5.1 .3-\mathrm{A} 3: \mathrm{d}\end{array}$ & & $\begin{array}{l}\text { Nenhuma } \\
\text { informação. }\end{array}$ & & 5.3.3: b, c. & \\
\hline Aderência & \multicolumn{2}{|c|}{$\begin{array}{l}4 \text { afirmações oriundas das } \\
\text { entrevistas e as fontes objetivas } \\
\text { comprovam a aderência } \\
\text { moderada da proposição na } \\
\text { Montadora A. }\end{array}$} & \multicolumn{2}{|c|}{$\begin{array}{l}\text { Nenhuma afirmação oriunda das } \\
\text { entrevistas e as fontes objetivas } \\
\text { comprovam a não aderência da } \\
\text { proposição na Montadora B. }\end{array}$} & \multicolumn{2}{|c|}{$\begin{array}{l}5 \text { afirmações oriundas das } \\
\text { entrevistas e as fontes objetivas } \\
\text { comprovam a aderência moderada } \\
\text { da proposição na Montadora C. }\end{array}$} \\
\hline
\end{tabular}

Fonte: elaborado pelo autor. 
Quadro 22.11 - Análise e classificação da relevância da proposição teórica P11 (Institucionalização).

P11: Cada projeto de melhoria deve contar com uma equipe adequada a sua complexidade, com comunicação efetiva e regular entre a equipe e outras funções e níveis organizacionais.

\begin{tabular}{|c|c|c|c|c|c|c|}
\hline \multirow[t]{2}{*}{ Entrevistado } & \multicolumn{2}{|c|}{ Montadora A } & \multicolumn{2}{|c|}{ Montadora B } & \multicolumn{2}{|c|}{ Montadora $\mathrm{C}$} \\
\hline & Entrevistas & Fontes objetivas & Entrevistas & Fontes objetivas & Entrevistas & Fontes objetivas \\
\hline Coordenador & $\begin{array}{l}\text { 5.1.1: h, 1, } \\
\text { m. }\end{array}$ & \multirow{3}{*}{$\begin{array}{l}\text { A equipe era } \\
\text { necessária } \\
\text { principalmente } \\
\text { em projetos } \\
\text { com } \\
\text { necessidade de } \\
\text { conhecimento } \\
\text { técnico } \\
\text { especializado, } \\
\text { mas o } \\
\text { alinhamento } \\
\text { com o gestor } \\
\text { era crítico. }\end{array}$} & $\begin{array}{l}\text { Nenhuma } \\
\text { informação. }\end{array}$ & \multirow{3}{*}{$\begin{array}{l}\text { Em diversos } \\
\text { projetos a } \\
\text { equipe atuou } \\
\text { apenas na fase } \\
\text { de } \\
\text { padronização, } \\
\text { para implantar } \\
\text { as melhorias } \\
\text { identificadas } \\
\text { pelo agente. }\end{array}$} & $\begin{array}{l}\text { Nenhuma } \\
\text { informação. }\end{array}$ & \multirow{3}{*}{$\begin{array}{l}\text { Assim como na } \\
\text { Montadora A, a } \\
\text { equipe tinha } \\
\text { uma } \\
\text { participação não } \\
\text { decisiva no } \\
\text { projeto, pois } \\
\text { cabia ao agente } \\
\text { articular } \\
\text { recursos para } \\
\text { conduzir o } \\
\text { projeto. }\end{array}$} \\
\hline Gestor & $\begin{array}{l}\text { Nenhuma } \\
\text { informação. }\end{array}$ & & $\begin{array}{l}\text { Nenhuma } \\
\text { informação. }\end{array}$ & & $\begin{array}{l}\text { Nenhuma } \\
\text { informação. }\end{array}$ & \\
\hline Agente & $\begin{array}{l}\text { 5.1.3-A1: c, } \\
\text { f. } \\
\text { 5.1.3-A2: h. }\end{array}$ & & 5.2.3-A1: a & & $\begin{array}{l}\text { Nenhuma } \\
\text { informação. }\end{array}$ & \\
\hline Aderência & \multicolumn{2}{|c|}{$\begin{array}{l}6 \text { afirmações oriundas das } \\
\text { entrevistas e as fontes objetivas } \\
\text { comprovam a aderência } \\
\text { moderada da proposição na } \\
\text { Montadora A. }\end{array}$} & \multicolumn{2}{|c|}{$\begin{array}{l}1 \text { afirmação oriunda das } \\
\text { entrevistas e as fontes objetivas } \\
\text { comprovam a não aderência da } \\
\text { proposição na Montadora B. }\end{array}$} & \multicolumn{2}{|c|}{$\begin{array}{l}\text { Nenhuma afirmação oriunda das } \\
\text { entrevistas e as fontes objetivas } \\
\text { comprovam a não aderência da } \\
\text { proposição na Montadora C. }\end{array}$} \\
\hline
\end{tabular}

Fonte: elaborado pelo autor. 
Quadro 22.12 - Análise e classificação da relevância da proposição teórica P12 (Institucionalização).

P12: Deve ser criado mecanismos de normalização e de incentivo a continuidade de atuação através de novos projetos de melhoria, que cheguem até o nível dos operadores.

\begin{tabular}{|c|c|c|c|c|c|c|}
\hline \multirow[t]{2}{*}{ Entrevistado } & \multicolumn{2}{|c|}{ Montadora A } & \multicolumn{2}{|c|}{ Montadora B } & \multicolumn{2}{|c|}{ Montadora C } \\
\hline & Entrevistas & Fontes objetivas & Entrevistas & Fontes objetivas & Entrevistas & Fontes objetivas \\
\hline Coordenador & $\begin{array}{l}\text { 5.1.1: o, p, t, } \\
\text { u. }\end{array}$ & \multirow{3}{*}{$\begin{array}{l}\text { Áreas de RH } \\
\text { (avaliação de } \\
\text { desempenho) e } \\
\text { Controladoria } \\
\text { (orçamento) não } \\
\text { envolvidas. A } \\
\text { grande maioria } \\
\text { dos agentes era } \\
\text { liderada por } \\
\text { gestores que } \\
\text { não acreditavam } \\
\text { no programa. } \\
\text { Um trabalho } \\
\text { abrangente de } \\
\text { mudança } \\
\text { atitudinal era } \\
\text { necessário. }\end{array}$} & 5.2.1: a, 1. & \multirow{3}{*}{$\begin{array}{l}\text { A área de RH } \\
\text { participou com } \\
\text { reportes ao } \\
\text { diretor de planta } \\
\text { e cobrando } \\
\text { maior apoio dos } \\
\text { gestores, para } \\
\text { agentes com } \\
\text { projetos } \\
\text { atrasados. O } \\
\text { modelo de } \\
\text { maturidade é na } \\
\text { verdade uma } \\
\text { abordagem de } \\
\text { normalização } \\
\text { muito forte para } \\
\text { iniciar novos } \\
\text { projetos. }\end{array}$} & 5.3.1: c, e, i & \\
\hline Gestor & $\begin{array}{l}\text { 5.1.2: a, c, d, } \\
\text { h, o. }\end{array}$ & & 5.2.2: $\mathrm{c}, \mathrm{d}$. & & $\begin{array}{l}\text { 5.1.2: a, c, d, h, } \\
\text { o. }\end{array}$ & \\
\hline Agente & $\begin{array}{l}\text { 5.1.3-A1: g. } \\
\text { 5.1.3-A2: c, } \\
\text { d, e, f } \\
\text { 5.1.3-A3: c }\end{array}$ & & 5.2.3-A2: b. & & 5.3.3: c, e, j. & \\
\hline Aderência & \multicolumn{2}{|c|}{$\begin{array}{l}15 \text { afirmações oriundas das } \\
\text { entrevistas e as fontes objetivas } \\
\text { comprovam a alta aderência da } \\
\text { proposição na Montadora A. }\end{array}$} & \multicolumn{2}{|c|}{$\begin{array}{l}5 \text { afirmações oriundas das } \\
\text { entrevistas e as fontes objetivas } \\
\text { comprovam a aderência moderada } \\
\text { da proposição na Montadora B. }\end{array}$} & \multicolumn{2}{|c|}{$\begin{array}{l}11 \text { afirmações oriundas das } \\
\text { entrevistas e as fontes objetivas } \\
\text { comprovam a alta aderência da } \\
\text { proposição na Montadora C. }\end{array}$} \\
\hline
\end{tabular}

Fonte: elaborado pelo autor. 
Quadro 22.13 - Análise e classificação da relevância da proposição teórica P13 (Institucionalização).

P13: Deve ser fomentado um ambiente de colaboração para com o agente interno, o que inclui canal de comunicação para esclarecimentos durante o projeto, valorização de trabalho em equipe e da autonomia.

\begin{tabular}{|c|c|c|c|c|c|c|}
\hline \multirow[t]{2}{*}{ Entrevistado } & \multicolumn{2}{|c|}{ Montadora A } & \multicolumn{2}{|c|}{ Montadora B } & \multicolumn{2}{|c|}{ Montadora $\mathrm{C}$} \\
\hline & Entrevistas & Fontes objetivas & Entrevistas & Fontes objetivas & Entrevistas & Fontes objetivas \\
\hline Coordenador & 5.1.1: a, h, 1 . & \multirow{3}{*}{$\begin{array}{l}\text { A maioria dos } \\
\text { gestores faltava } \\
\text { até na reunião de } \\
\text { acompanhamento } \\
\text { de fase dos } \\
\text { projetos. Quando } \\
\text { a autonomia para } \\
\text { modificar } \\
\text { processos era } \\
\text { muito restrita, o } \\
\text { projeto resultava } \\
\text { em soluções } \\
\text { paliativas. A } \\
\text { equipe não era } \\
\text { valorizada por } \\
\text { muitos agentes. }\end{array}$} & $\begin{array}{l}\text { Nenhuma } \\
\text { informação. }\end{array}$ & \multirow{3}{*}{$\begin{array}{l}\text { Na Montadora } \\
\text { B notou-se uma } \\
\text { comunicação } \\
\text { contínua entre } \\
\text { os líderes de } \\
\text { produção } \\
\text { treinados numa } \\
\text { espécie de rede } \\
\text { informal de } \\
\text { apoio e troca de } \\
\text { experiências, já } \\
\text { que eles } \\
\text { estavam sob } \\
\text { regime de total } \\
\text { imersão em } \\
\text { treinamento. }\end{array}$} & $\begin{array}{l}\text { Nenhuma } \\
\text { informação. }\end{array}$ & \multirow{3}{*}{$\begin{array}{l}\text { Assim como na } \\
\text { Montadora A, } \\
\text { esclarecimento } \\
\text { durante projetos } \\
\text { era feito pelo } \\
\text { coordenador e } \\
\text { pelo consultor } \\
\text { externo. Uma } \\
\text { folha A3 foi } \\
\text { criada para } \\
\text { servir de } \\
\text { sumário do } \\
\text { conhecimento } \\
\text { adquirido em } \\
\text { cada projeto. }\end{array}$} \\
\hline Gestor & 5.1.2: h. & & $5.2 .2: \mathrm{b}$ & & 5.1.2: h. & \\
\hline Agente & $\begin{array}{l}\text { 5.1.3-A1: c. } \\
\text { 5.1.3-A2: h. }\end{array}$ & & 5.2.3-A1: a & & 5.3.3: c & \\
\hline Aderência & \multicolumn{2}{|c|}{$\begin{array}{l}6 \text { afirmações oriundas das } \\
\text { entrevistas e as fontes objetivas } \\
\text { comprovam a aderência } \\
\text { moderada da proposição na } \\
\text { Montadora A. }\end{array}$} & \multicolumn{2}{|c|}{$\begin{array}{l}2 \text { afirmações oriundas das } \\
\text { entrevistas e as fontes objetivas } \\
\text { comprovam a aderência moderada } \\
\text { da proposição na Montadora B. }\end{array}$} & \multicolumn{2}{|c|}{$\begin{array}{l}4 \text { afirmações oriundas das } \\
\text { entrevistas e as fontes objetivas } \\
\text { comprovam a aderência moderada } \\
\text { da proposição na Montadora C. }\end{array}$} \\
\hline
\end{tabular}

Fonte: elaborado pelo autor.

Quadro 22.14 - Análise e classificação da relevância da proposição teórica P14 (Agência humana). 
Quadro 22.14 - Análise e classificação da relevância da proposição teórica P14 (Agência Humana).

P14: Deve ser atacada intencionalmente a cultura de busca aos culpados dos problemas.

\begin{tabular}{|c|c|c|c|c|c|c|}
\hline \multirow[t]{2}{*}{ Entrevistado } & \multicolumn{2}{|c|}{ Montadora A } & \multicolumn{2}{|c|}{ Montadora B } & \multicolumn{2}{|c|}{ Montadora C } \\
\hline & Entrevistas & Fontes objetivas & Entrevistas & Fontes objetivas & Entrevistas & Fontes objetivas \\
\hline Coordenador & $\begin{array}{l}\text { 5.1.1: b, c, j, } \\
\text { n, o. }\end{array}$ & \multirow{3}{*}{$\begin{array}{l}\text { Diversos relatos } \\
\text { de barreiras } \\
\text { entre áreas eram } \\
\text { devido ao medo } \\
\text { de expor dados } \\
\text { reais. Boa parte } \\
\text { dos projetos que } \\
\text { não sustentaram } \\
\text { resultados } \\
\text { pararam na } \\
\text { causa "erro } \\
\text { humano" ao } \\
\text { invés de atacar } \\
\text { a falha no } \\
\text { processo. }\end{array}$} & $\begin{array}{l}\text { Nenhuma } \\
\text { informação. }\end{array}$ & \multirow{3}{*}{$\begin{array}{l}\text { Alguns } \\
\text { indicadores não } \\
\text { refletiam as } \\
\text { perdas reais e as } \\
\text { melhorias, } \\
\text { embora reais, } \\
\text { não surtiam } \\
\text { efeitos no } \\
\text { desempenho } \\
\text { reportado. O } \\
\text { medo de ser } \\
\text { culpado } \\
\text { promove a } \\
\text { omissão de } \\
\text { informações } \\
\text { importantes } \\
\text { para o projeto. }\end{array}$} & 5.3.1: e. & \multirow{3}{*}{$\begin{array}{l}\text { Na Montadora } \\
\text { C, antes de } \\
\text { concluir que a } \\
\text { causa de uns } \\
\text { problemas } \\
\text { estava ligada ao } \\
\text { operador, foi } \\
\text { obrigatório a } \\
\text { investigação na } \\
\text { sequência de } 3 \\
\text { perguntas: 1) o } \\
\text { processo ajuda } \\
\text { a acertar? 2) a } \\
\text { qualificação é } \\
\text { suficiente? 3) o } \\
\text { perfil é } \\
\text { adequado? }\end{array}$} \\
\hline Gestor & $\begin{array}{l}\text { Nenhuma } \\
\text { informação. }\end{array}$ & & $\begin{array}{l}\text { Nenhuma } \\
\text { informação. }\end{array}$ & & $\begin{array}{l}\text { Nenhuma } \\
\text { informação. }\end{array}$ & \\
\hline Agente & $\begin{array}{l}\text { Nenhuma } \\
\text { informação. }\end{array}$ & & $\begin{array}{l}\text { 5.2.3-A1: c. } \\
5.2 .3-\mathrm{A} 2: \mathrm{d} . \\
5.2 .3-\mathrm{A} 3: \mathrm{b} .\end{array}$ & & $\begin{array}{l}\text { Nenhuma } \\
\text { informação. }\end{array}$ & \\
\hline Aderência & \multicolumn{2}{|c|}{$\begin{array}{l}5 \text { afirmações oriundas das } \\
\text { entrevistas e as fontes objetivas } \\
\text { comprovam a aderência } \\
\text { moderada da proposição na } \\
\text { Montadora A. }\end{array}$} & \multicolumn{2}{|c|}{$\begin{array}{l}3 \text { afirmações oriundas das } \\
\text { entrevistas e as fontes objetivas } \\
\text { comprovam a aderência moderada } \\
\text { da proposição na Montadora B. }\end{array}$} & \multicolumn{2}{|c|}{$\begin{array}{l}\text { 1 afirmação oriunda das } \\
\text { entrevistas e as fontes objetivas } \\
\text { comprovam a aderência moderada } \\
\text { da proposição na Montadora C. }\end{array}$} \\
\hline
\end{tabular}

Fonte: elaborado pelo autor. 
Quadro 22.15 - Análise e classificação da relevância da proposição teórica P15 (Institucionalização).

P15: Deve ser adotado um modelo de maturidade para formar e fortalecer uma cultura de melhoria, incluindo a melhoria do próprio processo de melhoria.

\begin{tabular}{|c|c|c|c|c|c|c|}
\hline \multirow[t]{2}{*}{ Entrevistado } & \multicolumn{2}{|c|}{ Montadora A } & \multicolumn{2}{|c|}{ Montadora B } & \multicolumn{2}{|c|}{ Montadora C } \\
\hline & Entrevistas & $\begin{array}{c}\text { Fontes } \\
\text { objetivas }\end{array}$ & Entrevistas & Fontes objetivas & Entrevistas & Fontes objetivas \\
\hline Coordenador & $\begin{array}{l}\text { 5.1.1: f, h, u, } \\
\text { v. }\end{array}$ & \multirow{3}{*}{$\begin{array}{l}\text { Assim como na } \\
\text { Montadora C, } \\
\text { quando a } \\
\text { melhoria é um } \\
\text { programa, fica } \\
\text { dependente das } \\
\text { pessoas. } \\
\text { Quando é um } \\
\text { modelo de } \\
\text { excelência com } \\
\text { pilares e } \\
\text { avaliação, } \\
\text { torna-se parte } \\
\text { da gestão do } \\
\text { dia-a-dia. }\end{array}$} & 5.2.1: a, d, 1 . & \multirow{3}{*}{$\begin{array}{l}\text { O modelo de } \\
\text { maturidade } \\
\text { adotado pela } \\
\text { Montadora B } \\
\text { torna a seleção de } \\
\text { projetos } \\
\text { automatizada e } \\
\text { rotineira, leve a } \\
\text { alta direção e } \\
\text { gerência a buscar } \\
\text { e melhoria e } \\
\text { agentes a } \\
\text { atuarem em } \\
\text { novos projetos } \\
\text { sistematicamente. }\end{array}$} & 5.3.1: $\mathrm{d}, \mathrm{f}, \mathrm{k}$. & \multirow{3}{*}{$\begin{array}{l}\text { Assim como na } \\
\text { Montadora A, } \\
\text { as pessoas } \\
\text { esperam da } \\
\text { liderança o } \\
\text { incentivo e } \\
\text { normatização } \\
\text { para que } \\
\text { projetos } \\
\text { aconteçam ao } \\
\text { invés de um } \\
\text { modelo de auto } \\
\text { avaliação e } \\
\text { crescimento. }\end{array}$} \\
\hline Gestor & 5.1.2: n, o. & & 5.2.2: c, d. & & 5.1.2: n, o. & \\
\hline Agente & $\begin{array}{l}\text { 5.1.3-A1: j. } \\
\text { 5.1.3-A2: c. } \\
\text { 5.1.3-A3: c. }\end{array}$ & & $5.2 .3-\mathrm{A} 3: \mathrm{b}$ & & 5.3.3: e, i. & \\
\hline Aderência & \multicolumn{2}{|c|}{$\begin{array}{l}9 \text { afirmações oriundas das } \\
\text { entrevistas e as fontes objetivas } \\
\text { comprovam a alta aderência da } \\
\text { proposição na Montadora A. }\end{array}$} & \multicolumn{2}{|c|}{$\begin{array}{l}6 \text { afirmações oriundas das } \\
\text { entrevistas e as fontes objetivas } \\
\text { comprovam a alta aderência da } \\
\text { proposição na Montadora B. }\end{array}$} & \multicolumn{2}{|c|}{$\begin{array}{l}7 \text { afirmações oriundas das } \\
\text { entrevistas e as fontes objetivas } \\
\text { comprovam a alta aderência da } \\
\text { proposição na Montadora C. }\end{array}$} \\
\hline
\end{tabular}

Fonte: elaborado pelo autor.

Quadro 22.16 - Análise e classificação da relevância da proposição teórica P15 (Institucionalização). 
P16: É necessário assegurar a estabilidade dos equipamentos para que os projetos de melhoria realizados pelos agentes internos tenham resultados sustentáveis.

\begin{tabular}{|c|c|c|c|c|c|c|}
\hline \multirow[t]{2}{*}{ Entrevistado } & \multicolumn{2}{|c|}{ Montadora A } & \multicolumn{2}{|c|}{ Montadora B } & \multicolumn{2}{|c|}{ Montadora $\mathrm{C}$} \\
\hline & Entrevistas & Fontes objetivas & Entrevistas & Fontes objetivas & Entrevistas & Fontes objetivas \\
\hline Coordenador & $\begin{array}{l}\text { Nenhuma } \\
\text { informação. }\end{array}$ & \multirow{3}{*}{$\begin{array}{l}\text { Em projetos } \\
\text { com influência } \\
\text { do desempenho } \\
\text { de máquinas } \\
\text { isto era verdade } \\
\text { na consolidação } \\
\text { dos resultados } \\
\text { esperados. }\end{array}$} & 5.2.1: h & \multirow{3}{*}{$\begin{array}{l}\text { Os projetos de } \\
\text { restauração de } \\
\text { padrões foram } \\
\text { implantados } \\
\text { para atacar as } \\
\text { causas de } \\
\text { instabilidade do } \\
\text { equipamento. }\end{array}$} & $\begin{array}{l}\text { Nenhuma } \\
\text { informação. }\end{array}$ & \multirow{3}{*}{$\begin{array}{l}\text { Por ser uma } \\
\text { planta mais } \\
\text { moderna a } \\
\text { automatizada do } \\
\text { que a } \\
\text { Montadora A, a } \\
\text { estabilidade dos } \\
\text { equipamentos } \\
\text { era muito } \\
\text { menos } \\
\text { impactante nas } \\
\text { perdas } \\
\text { industriais. }\end{array}$} \\
\hline Gestor & $\begin{array}{l}\text { Nenhuma } \\
\text { informação. }\end{array}$ & & $\begin{array}{l}\text { Nenhuma } \\
\text { informação. }\end{array}$ & & $\begin{array}{l}\text { Nenhuma } \\
\text { informação. }\end{array}$ & \\
\hline Agente & $\begin{array}{l}\text { 5.1.3-A1: b, } \\
\text { c. } \\
5.1 .3-\mathrm{A} 3: \mathrm{b}\end{array}$ & & $\begin{array}{l}\text { Nenhuma } \\
\text { informação. }\end{array}$ & & 5.3.3: f, i & \\
\hline Aderência & \multicolumn{2}{|c|}{$\begin{array}{l}3 \text { afirmações oriundas das } \\
\text { entrevistas e as fontes objetivas } \\
\text { demonstram a não aderência da } \\
\text { proposição na Montadora A. }\end{array}$} & \multicolumn{2}{|c|}{$\begin{array}{l}1 \text { afirmação oriunda das } \\
\text { entrevistas e as fontes objetivas } \\
\text { demonstram a não aderência da } \\
\text { proposição na Montadora B. }\end{array}$} & \multicolumn{2}{|c|}{$\begin{array}{l}2 \text { afirmações oriundas das } \\
\text { entrevistas e as fontes objetivas } \\
\text { demonstram a não aderência da } \\
\text { proposição na Montadora C. }\end{array}$} \\
\hline
\end{tabular}

Fonte: elaborado pelo autor. 
A classificação final da relevância das proposições teóricas, descritas nos Quadro 23.1 a 23.16 foi feita considerando três categorias: elementos relevantes, elementos moderadamente relevantes e elementos não relevantes na transformação de profissionais, membros da organização, em agentes internos de melhoria. Foi considerado como elemento relevante aquele que apresentar uma alta aderência em pelo menos duas montadoras. Foi considerado como elemento moderado aquele que apresentar aderência moderada em pelo menos duas montadoras. Demais elementos foram considerados não relevantes. A análise de evidências objetivas e as entrevistas em cada montadora foram consideradas nesta classificação.

Quadro 23.1 - Classificação da relevância da proposição teórica P1

\begin{tabular}{|l|l|l|l|}
\hline Proposição & $\begin{array}{c}\text { Montadora } \\
\text { A }\end{array}$ & $\begin{array}{c}\text { Montadora } \\
\text { B }\end{array}$ & $\begin{array}{c}\text { Montadora } \\
\text { C }\end{array}$ \\
\hline $\begin{array}{l}\text { P1: A transformação de profissionais, membros da } \\
\text { organização, em agentes internos de melhoria deve } \\
\text { ser vista como uma ação estratégica da alta direção. }\end{array}$ & $\begin{array}{l}\text { Alta } \\
\text { relevância }\end{array}$ & $\begin{array}{l}\text { Moderada } \\
\text { relevância }\end{array}$ & $\begin{array}{l}\text { Alta } \\
\text { relevância }\end{array}$ \\
\hline Conclusão sobre a relevância da proposição & \multicolumn{2}{|l|}{ Alta relevância } \\
\hline
\end{tabular}

Fonte: elaborado pelo autor.

Nas três montadoras foi observado a importância do comprometimento da alta direção com a iniciativa de melhoria. Vale ressaltar que o papel da direção foi diferente entre as montadoras. Nas Montadoras A e C, o compromisso da direção foi o de suportar a alocação de recursos para realizar o programa de capacitação e auxiliar na seleção e acompanhamento de projetos. Na Montadora B, o papel da direção não foi o de participar de projetos, e sim de estabelecer o modelo de maturidade de excelência nas operações. O modelo, por si só, reforça a responsabilidade dos gestores em atacar as perdas industriais através de projetos de melhoria usando metodologia estruturada para assegurar a sustentabilidade dos resultados alcançados.

Quadro 23.2 - Classificação da relevância da proposição teórica P2

\begin{tabular}{|l|l|l|l|}
\hline Proposição & $\begin{array}{l}\text { Montadora } \\
\text { A }\end{array}$ & $\begin{array}{l}\text { Montadora } \\
\text { B }\end{array}$ & $\begin{array}{l}\text { Montadora } \\
\text { C }\end{array}$ \\
\hline $\begin{array}{l}\text { P2: A transformação de profissionais, membros da } \\
\text { organização, em agentes internos de melhoria requer } \\
\text { um investimento de tempo e participação dos gestores } \\
\text { no apoio a realização de projetos de melhoria. }\end{array}$ & $\begin{array}{l}\text { Alta } \\
\text { relevância }\end{array}$ & $\begin{array}{l}\text { Alta } \\
\text { relevância }\end{array}$ & $\begin{array}{l}\text { Alta } \\
\text { relevância }\end{array}$ \\
\hline Conclusão sobre a relevância da proposição & \multicolumn{2}{|l|}{ Alta relevância } \\
\hline
\end{tabular}

Fonte: elaborado pelo autor. 
O apoio dos gestores na condução de projetos é um consenso entre todos os entrevistados e também foi verificado como um fator crítico de sucesso nos projetos que foram plenamente concluídos. Vale ressaltar que afirmações coletadas durante as entrevistas sobre tempo para realizar projetos e quebrar barreiras em demais áreas tem uma ligação direta com o apoio do gestor.

Quadro 23.3 - Classificação da relevância da proposição teórica P3

\begin{tabular}{|c|c|c|c|}
\hline Proposição & $\begin{array}{c}\text { Montadora } \\
\text { A }\end{array}$ & $\begin{array}{c}\text { Montadora } \\
\text { B }\end{array}$ & $\begin{array}{c}\text { Montadora } \\
\text { C }\end{array}$ \\
\hline $\begin{array}{l}\text { P3: Os profissionais selecionados para se tornarem } \\
\text { agentes internos de melhoria devem demonstrar } \\
\text { atitude favorável a melhoria e perceber-se capaz de } \\
\text { realizar projetos de melhoria. }\end{array}$ & $\begin{array}{l}\text { Alta } \\
\text { relevância }\end{array}$ & $\begin{array}{l}\text { Moderada } \\
\text { relevância }\end{array}$ & $\begin{array}{l}\text { Alta } \\
\text { relevância }\end{array}$ \\
\hline
\end{tabular}

Fonte: elaborado pelo autor.

Exemplos de aberturas de novos projetos nas Montadoras A e C, onde a estrutura do programa foi excluída em 2016, associadas com a entrevistas destes profissionais e sua percepção de importância de realizar projetos de melhoria de forma estruturada, são fortes evidências que tornam esta proposição relevante. Por exemplo, um dos agentes entrevistados no Montadora A, a que teve pior resultados ligados aos projetos de melhoria, relata que após a qualificação inicial adotou a metodologia de projetos de melhoria aprendida como um modelo mental. Este agente tem conseguido superar barreiras institucionais e continuar a conduzir projetos, em 2 casos observados, concluídos plenamente. $\mathrm{O}$ que muda para os profissionais com este modelo mental é que mesmo em tempo de crise econômica na indústria automobilística, os projetos continuaram a ser abetos, porém mudando o enfoque de qualidade para a redução de custo.

Quadro 23.4 - Classificação da relevância da proposição teórica P4

\begin{tabular}{|l|c|c|l|}
\hline Proposição & Montadora & Montadora & $\begin{array}{c}\text { Montadora } \\
\text { C }\end{array}$ \\
\hline $\begin{array}{l}\text { P4: Os profissionais selecionados para se tornarem } \\
\text { agentes internos de melhoria devem conhecer as }\end{array}$ & $\begin{array}{l}\text { Moderada } \\
\text { relevância }\end{array}$ & $\begin{array}{l}\text { Moderada } \\
\text { relevância }\end{array}$ & $\begin{array}{l}\text { Alta } \\
\text { relevância }\end{array}$ \\
\hline
\end{tabular}


metas organizacionais e estarem no nível organizacional adequado com a maturidade do programa (quanto menos madura a melhoria contínua, maior o nível hierárquico necessário).

Conclusão sobre a relevância da proposição

Fonte: elaborado pelo autor.

Embora um nível hierárquico apropriado seja fator importante, não se observou que é condição indispensável para a transformação dos profissionais. Isto foi comprovado por analisar o sucesso de projetos conduzidos por agentes no primeiro nível de liderança da produção na Montadora B. Eles continuam a realizar projetos porque existe um sistema de seleção e estrutura de apoio de projetos adequada que é parte do modelo de maturidade em excelência de operações. $\mathrm{Na}$ ausência deste sistema estruturado da Montadora B, que é o caso das Montadoras A e C, a participação ativa dos gestores foi fundamental, ou seja, o nível hierárquico deve ser maior para que as barreiras organizacionais se dissolvam e os projetos se concretizem.

Quadro 23.5 - Classificação da relevância da proposição teórica P5

\begin{tabular}{|l|l|l|l|}
\hline Proposição & $\begin{array}{c}\text { Montadora } \\
\text { A }\end{array}$ & $\begin{array}{c}\text { Montadora } \\
\text { B }\end{array}$ & $\begin{array}{c}\text { Montadora } \\
\text { C }\end{array}$ \\
\hline $\begin{array}{l}\text { P5: Deve-se desenvolver a habilidade do agente } \\
\text { interno de melhoria em aplicar na prática uma } \\
\text { metodologia e ferramentas de solução de problemas } \\
\text { de acordo com o tipo de projeto e dos processos } \\
\text { organizacionais. }\end{array}$ & $\begin{array}{l}\text { Moderada } \\
\text { relevância }\end{array}$ & $\begin{array}{c}\text { Moderada } \\
\text { relevância }\end{array}$ & $\begin{array}{c}\text { Moderada } \\
\text { relevância }\end{array}$ \\
\hline Conclusão sobre a relevância da proposição & \multicolumn{2}{|l|}{} \\
\hline
\end{tabular}

Fonte: elaborado pelo autor.

A aplicação de ferramentas depende não só da aquisição de habilidades pelo agente, mas também de superação de questões políticas e fragilidades tecnológicas e do apoio da consultoria externa na realização dos projetos. Mesmo na Montadora B, onde a carga e escopo de treinamento foram elevadas e abrangentes, ao analisar os projetos concluídos com sucesso, se observa que não foi necessário o uso de ferramentas avançadas, como as estatísticas, para o alcance da melhoria, e sim a aplicação de um raciocínio lógico de observação de fenômenos, analise dos dados e tomada de decisão. 
Quadro 23.6 - Classificação da relevância da proposição teórica P6

\begin{tabular}{|l|l|l|l|}
\hline Proposição & Montadora & Montadora & Montadora \\
B & C \\
\hline $\begin{array}{l}\text { P6: Deve-se desenvolver a habilidade do agente } \\
\text { interno de melhoria em gerenciamento de tempo, } \\
\text { gerenciamento de conflito, delegação, aceitação a } \\
\text { mudança e pensamento sistêmico. }\end{array}$ & $\begin{array}{l}\text { Alta } \\
\text { relevância }\end{array}$ & $\begin{array}{l}\text { Moderada } \\
\text { relevância }\end{array}$ & $\begin{array}{l}\text { Alta } \\
\text { relevância }\end{array}$ \\
\hline Conclusão sobre a relevância da proposição & Alta relevância \\
\hline
\end{tabular}

Fonte: elaborado pelo autor.

$\mathrm{Na}$ Montadora B observou-se projetos conduzidos por agentes mais experientes e com baixa escolaridade e que tinham dificuldades de compreensão metodológica evidenciada pelos resultados dos exames finais. Esta limitação foi superada em parte pela habilidade de mobilizar o time de produção para identificar e implantar as melhorias e assim alcançar as metas do projeto. Mais importante do que as habilidades metodológicas para realizar o projeto, foram as habilidades comportamentais de influência da equipe e obtenção de patrocínio interno. Embora não se pode observar a lista de habilidades comportamentais da proposição, as afirmações e evidências documentais observadas nas montadoras têm uma forte ligação com a proposição $\mathrm{P} 3$, também classificada como um aspecto ligado mais a agência humana, pois são habilidades que propiciam o agente a sentir-se capaz de conduzir projetos.

Quadro 23.7 - Classificação da relevância da proposição teórica P7

\begin{tabular}{|l|l|l|l|}
\hline Proposição & $\begin{array}{c}\text { Montadora } \\
\text { A }\end{array}$ & $\begin{array}{c}\text { Montadora } \\
\text { B }\end{array}$ & $\begin{array}{c}\text { Montadora } \\
\text { C }\end{array}$ \\
\hline $\begin{array}{l}\text { P7: O coordenador de melhoria contínua deve ser } \\
\text { escolhido cuidadosamente e ter dedicação de tempo } \\
\text { integral na função. }\end{array}$ & $\begin{array}{l}\text { Não } \\
\text { aderente }\end{array}$ & $\begin{array}{l}\text { Moderada } \\
\text { relevância }\end{array}$ & $\begin{array}{l}\text { Moderada } \\
\text { relevância }\end{array}$ \\
\hline Conclusão sobre a relevância da proposição & \multicolumn{2}{|l|}{ Moderada relevância } \\
\hline
\end{tabular}

Fonte: elaborado pelo autor.

A existência de apoio pelo coordenador de melhoria só foi necessária para projetos em que o gestor não participava e apoiava o agente interno. Isto porque o apoio político de quebrar barreiras departamentais e prover recursos deveria vir do gestor e da alta direção. O apoio técnico deveria vir da equipe de projeto. $\mathrm{O}$ apoio metodológico deveria vir do consultor externo e eventualmente do coordenador de melhoria. Ao supor que o coordenador cumpre 
um pouco de cada papel, na realidade o pode ocorrer é o não comprometimento dos demais atores em seus papeis. É importante ressaltar a fun outro tipo de coordenador que existe na Montadora B: o coordenador de pilar. Este coordenador auxilia na implantação do pilar de excelência operacional das áreas produtivas, não na abertura de projetos de melhoria pontuais.

Quadro 23.8 - Classificação da relevância da proposição teórica P8

\begin{tabular}{|l|l|l|l|}
\hline Proposição & Montadora & Montadora & Montadora \\
\hline $\begin{array}{l}\text { P8: O projeto deve ter objetivo mensurável, alinhado } \\
\text { com a estratégia organizacional, de apuração de } \\
\text { resultado não ambígua. }\end{array}$ & $\begin{array}{l}\text { Alta } \\
\text { relevância }\end{array}$ & $\begin{array}{l}\text { Moderada } \\
\text { relevância }\end{array}$ & $\begin{array}{l}\text { Alta } \\
\text { relevância }\end{array}$ \\
\hline Conclusão sobre a relevância da proposição & Alta relevância \\
\hline
\end{tabular}

Fonte: elaborado pelo autor.

O nível moderado de afirmações ligadas aos objetivos de projeto é devido a este fator ser intrínseco para se iniciar um projeto. Um objetivo mensurável e não ambíguo é um elemento dado como certo e fundamental nas três montadoras.

Quadro 23.9 - Classificação da relevância da proposição teórica P9

\begin{tabular}{|l|l|l|l|}
\hline Proposição & $\begin{array}{c}\text { Montadora } \\
\text { A }\end{array}$ & $\begin{array}{c}\text { Montadora } \\
\text { B }\end{array}$ & $\begin{array}{c}\text { Montadora } \\
\text { C }\end{array}$ \\
\hline $\begin{array}{l}\text { P9: Deve ser estabelecido um processo de gestão do } \\
\text { conhecimento, capaz de resgatar e utilizar o } \\
\text { conhecimento gerado em projetos anteriores, que } \\
\text { facilite a condução de novos projetos otimizando o } \\
\text { estado futuro já alcançado em projetos anteriores. }\end{array}$ & $\begin{array}{c}\text { Moderada } \\
\text { relevância }\end{array}$ & $\begin{array}{c}\text { Moderada } \\
\text { relevância }\end{array}$ & $\begin{array}{c}\text { Moderada } \\
\text { relevância }\end{array}$ \\
\hline Conclusão sobre a relevância da proposição & & \\
\end{tabular}

Fonte: elaborado pelo autor.

A gestão do conhecimento está intimamente relacionada com a proposição P10 e P15, através da prática de selecionar novos projetos por meio de extensão de lições aprendidas, reforçada pelos modelos de maturidade. Isto é muito importante para que os novos projetos aproveitem das lições aprendidas anteriores e acelerem a obtenção de resultados em processos similares, mas não é condição indispensável para a transformação dos agentes. No caso da Montadora $\mathrm{B}$, cada agente de melhoria escolhia o projeto a partir da estratificação das perdas e não a partir de projetos similares, e ainda sim obteve um alto índice de conclusão de projetos. 
Quadro 23.10 - Classificação da relevância da proposição teórica P10

\begin{tabular}{|l|l|l|l|}
\hline Proposição & $\begin{array}{c}\text { Montadora } \\
\text { A }\end{array}$ & $\begin{array}{c}\text { Montadora } \\
\text { B }\end{array}$ & $\begin{array}{c}\text { Montadora } \\
\text { C }\end{array}$ \\
\hline $\begin{array}{l}\text { P10: Deve estar implantada uma sistemática de } \\
\text { seleção de projetos com critérios objetivos e uma } \\
\text { função de coordenação de portfólio de projetos. }\end{array}$ & $\begin{array}{l}\text { Moderada } \\
\text { relevância }\end{array}$ & $\begin{array}{l}\text { Não } \\
\text { relevante }\end{array}$ & $\begin{array}{l}\text { Moderada } \\
\text { relevância }\end{array}$ \\
\hline Conclusão sobre a relevância da proposição & \multicolumn{2}{|l|}{ Moderada relevância } \\
\hline
\end{tabular}

Fonte: elaborado pelo autor.

Uma boa seleção e coordenação do portfólio de projetos é importante, mas não indispensável na transformação de profissionais em agentes internos de melhoria. $\mathrm{O}$ sistema de seleção de projetos na Montadora B é feito através de uma estratificação das perdas industriais. O agente pode consultar quais perdas são as mais impactantes no desempenho de sua área e selecionar o projeto. Isto facilita muito a escolha de projetos com critérios objetivos e faz parte do modus operandi da empresa. Como a única forma de se abrir um projeto de melhoria formalmente reconhecido pela empresa é através deste sistema de estratificação de perdas, isto não apareceu como significativo nas entrevistas porque esta é uma condição sem a qual não se pode iniciar projetos de melhoria.

Quadro 23.11 - Classificação da relevância da proposição teórica P11

\begin{tabular}{|l|l|l|l|}
\hline Proposição & Montadora & Montadora & Montadora \\
B & C \\
\hline $\begin{array}{l}\text { P11: Cada projeto de melhoria deve contar com uma } \\
\text { equipe adequada a sua complexidade, com } \\
\text { comunicação efetiva e regular entre a equipe e outras } \\
\text { funções e níveis organizacionais. }\end{array}$ & $\begin{array}{l}\text { Moderada } \\
\text { relevância }\end{array}$ & $\begin{array}{l}\text { Não } \\
\text { relevante }\end{array}$ & $\begin{array}{l}\text { Não } \\
\text { relevante }\end{array}$ \\
\hline Conclusão sobre a relevância da proposição & Não relevante \\
\hline
\end{tabular}

Fonte: elaborado pelo autor.

A equipe de projeto apoia a condução do projeto, mas não é uma condição necessária para a transformação dos profissionais em agentes de melhoria. Em especial nas Montadoras B e C, onde os projetos foram liderados por pessoal com nível de liderança, a autonomia para mobilizar sua própria equipe de trabalho na realização do projeto era muito elevada. $\mathrm{Na}$ realidade, os fatores relevantes observados foram o apoio gerencial e a adoção de modelo de maturidade, proposições teóricas $\mathrm{P} 2$ e P 15, respectivamente. 
Quadro 23.12 - Classificação da relevância da proposição teórica P12

\begin{tabular}{|c|c|c|c|}
\hline Proposição & $\begin{array}{c}\text { Montadora } \\
\text { A }\end{array}$ & $\begin{array}{c}\text { Montadora } \\
\text { B }\end{array}$ & $\begin{array}{c}\text { Montadora } \\
\text { C }\end{array}$ \\
\hline $\begin{array}{l}\text { P12: Deve ser criado mecanismos de normalização e } \\
\text { de incentivo a continuidade de atuação através de } \\
\text { novos projetos de melhoria, que cheguem até o nível } \\
\text { dos operadores. }\end{array}$ & $\begin{array}{l}\text { Alta } \\
\text { relevância }\end{array}$ & $\begin{array}{l}\text { Moderada } \\
\text { relevância }\end{array}$ & $\begin{array}{l}\text { Alta } \\
\text { relevância }\end{array}$ \\
\hline Conclusão sobre a relevância da proposição & \multicolumn{3}{|c|}{ Alta relevância } \\
\hline
\end{tabular}

Fonte: elaborado pelo autor.

Após a saída do diretor de planta na Montadora $\mathrm{C}$ que puxava a apresentação de projetos a quantidade de novos projetos reduziu sensivelmente, fato também explicado pela redução de quadro e consecutivos lay-offs devido à crise econômica. Já na Montadora B, onde o Diretor de Planta e toda a estrutura gerencial é avaliada quanto aos avanços no nível de excelência das operações, a abertura de novos projetos é o principal meio de atingir o desempenho profissional esperado das funções de liderança na área produtiva.

Quadro 23.13 - Classificação da relevância da proposição teórica P13

\begin{tabular}{|l|l|l|l|}
\hline Proposição & $\begin{array}{c}\text { Montadora } \\
\text { A }\end{array}$ & $\begin{array}{c}\text { Montadora } \\
\text { B }\end{array}$ & $\begin{array}{c}\text { Montadora } \\
\text { C }\end{array}$ \\
\hline $\begin{array}{l}\text { P13: Deve ser fomentado um ambiente de de } \\
\text { colaboração para com o agente interno, o que inclui } \\
\text { canal de comunicação para esclarecimentos durante o } \\
\text { projeto, valorização de trabalho em equipe e da } \\
\text { autonomia. }\end{array}$ & $\begin{array}{l}\text { Moderada } \\
\text { relevância }\end{array}$ & $\begin{array}{l}\text { Moderada } \\
\text { relevância }\end{array}$ & $\begin{array}{c}\text { Moderada } \\
\text { relevância }\end{array}$ \\
\hline Conclusão sobre a relevância da proposição & \multicolumn{2}{|l|}{} \\
\hline
\end{tabular}

Fonte: elaborado pelo autor.

A autonomia e comunicação durante o projeto são fatores importantes na capacitação, mas não asseguram a transformação do profissional em agente de melhoria. Como observado na Montadora A, um dos agentes de melhoria continuou a realizar projetos mesmo num ambiente com a chefia desfavorável ao uso de metodologia estruturada. Isto remete a importância de consideração do aspecto da agência humana, onde o profissional não só espera a criação de um ambiente de colaboração de forma passiva para realizar projetos de melhoria, o que é importante, mas também onde o profissional é o agente transformador que participa da criação deste ambiente de colaboração. 
Quadro 23.14 - Classificação da relevância da proposição teórica P14

\begin{tabular}{|l|l|l|l|}
\hline Proposição & Montadora & Montadora & $\begin{array}{c}\text { Montadora } \\
\text { A }\end{array}$ \\
\hline $\begin{array}{l}\text { P14: Deve ser atacada intencionalmente a cultura de } \\
\text { busca aos culpados dos problemas. }\end{array}$ & $\begin{array}{l}\text { Moderada } \\
\text { relevância }\end{array}$ & $\begin{array}{l}\text { Moderada } \\
\text { relevância }\end{array}$ & $\begin{array}{l}\text { Moderada } \\
\text { relevância }\end{array}$ \\
\hline Conclusão sobre a relevância da proposição & \multicolumn{2}{|l|}{ Moderada relevância } \\
\hline
\end{tabular}

Fonte: elaborado pelo autor.

Embora com poucos relatos diretos dos entrevistados, em inúmeros projetos o medo de expor e tratar fragilidades do processo levou os agentes a operarem no modelo mental "problema devido a falha do operador". Nestes casos, durante o acompanhamento de projetos, o consultor avaliava a etapa de análise de causa como insuficiente e o agente deveria retornar ao processo e identificar a real causa raiz do problema ou perda a ser atacada no projeto.

Quadro 23.15 - Classificação da relevância da proposição teórica P15

\begin{tabular}{|l|l|l|l|}
\hline Proposição & $\begin{array}{l}\text { Montadora } \\
\text { A }\end{array}$ & $\begin{array}{l}\text { Montadora } \\
\text { B }\end{array}$ & $\begin{array}{l}\text { Montadora } \\
\text { C }\end{array}$ \\
\hline $\begin{array}{l}\text { P15: Deve ser adotado um modelo de maturidade } \\
\text { para formar e fortalecer uma cultura de melhoria, } \\
\text { incluindo a melhoria do próprio processo de } \\
\text { melhoria. }\end{array}$ & $\begin{array}{l}\text { Alta } \\
\text { relevância }\end{array}$ & $\begin{array}{l}\text { Alta } \\
\text { relevância }\end{array}$ & $\begin{array}{l}\text { Alta } \\
\text { relevância }\end{array}$ \\
\hline Conclusão sobre a relevância da proposição & Alta relevância \\
\hline
\end{tabular}

Fonte: elaborado pelo autor.

O modelo de maturidade coloca na pauta do dia-a-dia a questão: Como posso melhorar? Sem ele os profissionais perguntam: O que meu chefe ou direção espera? Isto é evidenciado na elevada abertura de novos projetos na Montadora B. Este modelo não substitui a importância do apoio do gestor, mas soma a este aspecto o fato da empresa ter um mecanismo que demonstra o patamar de desempenho atual, as perdas que justificam este patamar e que devem ser atacadas para que se chegue ao próximo nível de desempenho. Em empresas que não possuem um modelo de maturidade que é monitorado pela alta direção, como nas Montadoras A e C, a tendência dos programas de capacitação é apenas prover habilidades aos profissionais, ao invés de torna-los agentes internos de melhoria que continuam a desempenhar projetos após o término da capacitação inicial. 
Quadro 23.16 - Classificação da relevância da proposição teórica P16

\begin{tabular}{|l|l|l|l|}
\hline Proposição & $\begin{array}{l}\text { Montadora } \\
\text { A }\end{array}$ & $\begin{array}{l}\text { Montadora } \\
\text { B }\end{array}$ & $\begin{array}{l}\text { Montadora } \\
\text { C }\end{array}$ \\
\hline $\begin{array}{l}\text { P16: É necessário assegurar a estabilidade dos } \\
\text { equipamentos para que os projetos de melhoria } \\
\text { realizados pelos agentes internos tenham resultados } \\
\text { sustentáveis. }\end{array}$ & $\begin{array}{l}\text { Não } \\
\text { relevante }\end{array}$ & $\begin{array}{l}\text { Não } \\
\text { relevante }\end{array}$ & $\begin{array}{l}\text { Não } \\
\text { relevante }\end{array}$ \\
\hline Conclusão sobre a relevância da proposição & Não relevante & \\
\hline
\end{tabular}

Fonte: elaborado pelo autor.

A estabilidade dos equipamentos está muito mais ligada a sustentação dos resultados do que a transformação de profissionais em agentes internos. Nos projetos da área de manutenção, pode-se observar a importância desta afirmação, mas não se pode considerar que esta é uma condição necessária para transformação de profissionais em agentes internos de melhoria.

5.5.2) Achados da pesquisa de campo não ligados diretamente as proposições teóricas Algumas informações da pesquisa de campo, ora obtidas a partir das entrevistas, ora a partir de observação de continuidade de execução de projetos por alguns dos agentes internos capacitados, não tiveram uma relação tão direta com as proposições teóricas oriundas da revisão bibliográfica. No Quadro 24 estão descritos estes achados e as propostas de novas proposições teóricas a serem testadas em futuras pesquisas.

Quadro 24 - Achados da pesquisa de campo não ligados diretamente as proposições teóricas

\begin{tabular}{|l|l|}
\hline $\begin{array}{l}\text { Achados da pesquisa de campo não ligados } \\
\text { diretamente as proposições teóricas }\end{array}$ & $\begin{array}{l}\text { Novas proposições teóricas de elementos } \\
\text { relevantes para a transformação de profissionais } \\
\text { em agentes internos de melhoria }\end{array}$ \\
\hline $\begin{array}{l}\text { Os profissionais que tem em suas funções } \\
\text { cotidianas a necessidade de resolução de } \\
\text { problemas usando metodologia estruturada, tem } \\
\text { mais facilidade em abrir novos projetos de } \\
\text { melhoria de forma sistemática, já que isto está } \\
\text { alinhado com a sua responsabilidade primária. }\end{array}$ & $\begin{array}{l}\text { N1: Aplicar o processo de capacitaço nos } \\
\text { profissionais que já tem nas suas funções } \\
\text { cotidianas a necessidade de resolução de } \\
\text { problemas, para criar uma massa crítica de } \\
\text { melhoria mais natural e rotineira }\end{array}$ \\
$\begin{array}{l}\text { Isto foi amplamente observado nos agentes } \\
\text { treinados da área de garantia da Montadora A. }\end{array}$ & \\
\hline $\begin{array}{l}\text { Com a crise econômica na economia brasileira } \\
\text { nos anos de 2015 e 2016 o programa de } \\
\text { melhoria nas Montadoras A e C foi desativado. }\end{array}$ & $\begin{array}{l}\text { N2: Num ambiente de recessão econômica os } \\
\text { agentes internos deveriam iniciar projetos de } \\
\text { melhoria ligados a questões relevantes do }\end{array}$ \\
\hline
\end{tabular}




\begin{tabular}{|c|c|}
\hline $\begin{array}{l}\text { Ainda assim alguns profissionais, da área de } \\
\text { garantia da Montadora A continuaram realizando } \\
\text { projetos, só que ao invés de ter como } \\
\text { direcionador a melhoria da qualidade, o novo } \\
\text { direcionador foi a redução de custo. }\end{array}$ & $\begin{array}{l}\text { contexto atual, reforçando uma percepção } \\
\text { positiva e agregadora }\end{array}$ \\
\hline $\begin{array}{l}\text { As barreiras para ganho de autonomia para } \\
\text { desempenhar projetos e promoção de mudanças } \\
\text { em processos produtivos, não ocorreram nos } \\
\text { projetos conduzidos por líderes de produção das } \\
\text { Montadoras B e C, fato que é evidenciado pelo } \\
\text { alto índice de conclusão com sucesso dos } \\
\text { projetos iniciados. }\end{array}$ & $\begin{array}{l}\text { N3: Os líderes de produção são atores } \\
\text { fundamentais para a construção de um motor de } \\
\text { geração de novos projetos de melhoria, e ao se } \\
\text { tornarem agentes internos de melhoria, irão } \\
\text { contribuir com seus projetos próprios e os } \\
\text { projetos de outras funções que precisarão de } \\
\text { comprometimento da produção para implantar e } \\
\text { sustentar melhorias }\end{array}$ \\
\hline $\begin{array}{l}\text { Os gestores que conseguiram participar das } \\
\text { reuniões de acompanhamento e apoiar a } \\
\text { realização dos projetos incorporaram esta } \\
\text { atividade de melhoria em sua rotina diária. Foi } \\
\text { observado a existência de reuniões de } \\
\text { acompanhamento semanais sobre o avanço do } \\
\text { projeto nos gestores de garantia da Montadora } \\
\text { A. Na Montadora C, o próprio diretor de planta } \\
\text { tinha na sua agenda um tempo alocado para } \\
\text { rever projetos em atraso ou com problemas } \\
\text { metodológicos e solicitar medidas corretivas } \\
\text { junto aos gestores. }\end{array}$ & $\begin{array}{l}\text { N4: O apoio aos agentes de melhoria na } \\
\text { realização de projetos deve fazer parte de uma } \\
\text { rotina padronizada dos gestores e não ser } \\
\text { acidental. }\end{array}$ \\
\hline
\end{tabular}

Fonte: elaborado pelo autor. 


\section{CONCLUSÕES E CONSIDERAÇÕES FINAIS}

Este estudo originou-se a partir de uma problemática observada na indústria automobilística: a simples prescrição e aplicação, por parte da consultoria externa, de boas práticas de treinamento em metodologias e ferramentas de solução de problemas não tem sido suficiente para perenizar a atividade de melhoria contínua no dia-a-dia de operações, dado que os profissionais capacitados não realizam sistematicamente a condução de novos projetos de melhoria após sua qualificação inicial. Ora, a melhoria contínua é considerada uma prática essencial na estratégia de operações das principais montadoras globais (Netland, 2013), o que torna a criticidade desta problemática elevada. Daí surgiu a questão de pesquisa:

- Quais elementos são relevantes na transformação efetiva de profissionais, membros da organização, em agentes internos de melhoria contínua, na indústria automobilística?

Para responder esta questão buscou-se descrever e analisar como tornar mais efetivos os esforços de transformação de profissionais, membros da organização, em agentes internos de melhoria na indústria automobilística, que é o objetivo geral desta pesquisa.

Foram pesquisadas três montadoras instaladas no Brasil que contrataram uma consultoria externa para apoiá-las na implantação do programa de capacitação de seus profissionais. $\mathrm{O}$ presente pesquisador atuou como consultor externo nestes programas, o que permitiu acesso a informações e observações diretas entre os anos 2012 a 2016. A pesquisa revelou que nas três montadoras o propósito do processo de capacitação foi o de formar profissionais capazes de realizar projetos de melhoria de forma contínua, e que apenas na Montadora B este propósito foi alcançado, conforme resultados apresentados no Quadro 21.

Foram formuladas 16 proposições teóricas a partir do referencial teórico. Estas proposições foram testadas quanto a sua relevância através da análise de entrevistas junto a coordenadores, gestores e agentes internos das Montadoras A, B e $\mathrm{C}$ e de fontes documentais destas montadoras, o que inclui 410 projetos de melhoria e outras fontes de evidência ligadas a realização de projetos de melhoria. 
As seguintes proposições teóricas foram identificadas como tendo alta relevância na transformação de profissionais em agentes internos de melhoria:

P1: A transformação de profissionais, membros da organização, em agentes internos de melhoria deve ser vista como uma ação estratégica da alta direção.

P2: A transformação de profissionais, membros da organização, em agentes internos de melhoria requer um investimento de tempo e participação dos gestores no apoio a realização de projetos de melhoria.

P3: Os profissionais selecionados para se tornarem agentes internos de melhoria devem demonstrar atitude favorável a melhoria e perceber-se capaz de realizar projetos de melhoria. P6: Deve-se desenvolver a habilidade do agente interno de melhoria em gerenciamento de tempo, gerenciamento de conflito, delegação, aceitação a mudança e pensamento sistêmico.

P8: O projeto deve ter objetivo mensurável, alinhado com a estratégia organizacional, de apuração de resultado não ambígua.

P12: Deve ser criado mecanismos de normalização e de incentivo a continuidade de atuação através de novos projetos de melhoria, que cheguem até o nível dos operadores.

P15: Deve ser adotado um modelo de maturidade para formar e fortalecer uma cultura de melhoria, incluindo a melhoria do próprio processo de melhoria.

As seguintes proposições teóricas foram identificadas como tendo relevância moderada na transformação de profissionais em agentes internos de melhoria:

P4: Os profissionais selecionados para se tornarem agentes internos de melhoria devem conhecer as metas organizacionais e estarem no nível organizacional adequado com a maturidade do programa (quanto menos madura a melhoria contínua, maior o nível hierárquico necessário).

P5: Deve-se desenvolver a habilidade do agente interno de melhoria em aplicar na prática uma metodologia e ferramentas de solução de problemas de acordo com o tipo de projeto e dos processos organizacionais.

P7: O coordenador de melhoria contínua deve ser escolhido cuidadosamente e ter dedicação de tempo integral na função.

P9: Deve ser estabelecido um processo de gestão do conhecimento, capaz de resgatar e utilizar o conhecimento gerado em projetos anteriores, que facilite a condução de novos projetos otimizando o estado futuro já alcançado em projetos anteriores. 
P10: Deve estar implantada uma sistemática de seleção de projetos com critérios objetivos e uma função de coordenação de portfólio de projetos.

P13: Deve ser fomentado um ambiente de colaboração para com o agente interno, o que inclui canal de comunicação para esclarecimentos durante o projeto, valorização de trabalho em equipe e da autonomia.

P14: Deve ser atacada intencionalmente a cultura de busca aos culpados dos problemas.

As seguintes proposições teóricas foram identificadas como não sendo relevante na transformação de profissionais em agentes internos de melhoria:

P11: Cada projeto de melhoria deve contar com uma equipe adequada a sua complexidade, com comunicação efetiva e regular entre a equipe e outras funções e níveis organizacionais.

P16: É necessário assegurar a estabilidade dos equipamentos para que os projetos de melhoria realizados pelos agentes internos tenham resultados sustentáveis.

Os elementos identificados como de alta ou moderada relevância na transformação de profissionais em agentes internos de melhoria confirmam a fundamentação teórica em dois eixos conceituais propostos por este autor: institucionalização de melhoria e agência humana.

Por exemplo, um elemento altamente ligado a institucionalização é a adoção de um modelo de maturidade, relatado na proposição P15. O que pôde-se observar ao comparar os resultados das Montadoras A e C, que não possuem um modelo de maturidade, é que elas encaram a melhoria contínua como um programa, e estão sujeitas ao enfraquecimento da atividade quando ocorre troca da direção ou gestores. Empresas que adotam modelo de maturidade de melhoria contínua patrocinado pelo grupo tem maior estabilidade, por não depender de direção e gestão locais.

Embora pôde-se observar, através de baixo número de agentes das Montadoras A e C que continuaram a realizar projetos após o término da capacitação inicial, que a probabilidade de transformação de um profissional em agente interno de melhoria sem a presença de elementos de institucionalização é remota, ela acontece quando o profissional adota uma postura ativa diante dos obstáculos a realização dos projetos. Para que esta transformação aconteça, o que foi observado nestes casos das Montadoras A e C, o profissional integra a metodologia 
aprendida para resolver os problemas e atingir metas no seu dia-a-dia e enxerga que esta conduta possibilita ou possibilitará tanto crescimento pessoal quanto na carreira.

O peso de cada um destes elementos requer uma leitura adequada do contexto organizacional, dos processos e estruturas existentes, dos recursos disponíveis e das pessoas que deverão transformar-se em agentes internos de melhoria. Ressalta-se aqui a regência do verbo transformar no reflexivo. O máximo que consultores, direção e gestores podem fazer é a criação de circunstâncias favoráveis a ocorrência da transformação, mas em última instância, trata-se aqui do processo de transformar-se em agente interno de melhoria.

Elementos relevantes puderam ser identificados. Mas qual é a dosagem de cada um deles, a ser tomada em cada caso? Em que ordem deverão ser considerados? Quais riscos poderão ser aceitáveis, ao não endereçar um dos elementos relevantes? Dada a complexidade e desdobramento desta decisão na sustentabilidade da própria iniciativa de melhoria contínua, é importante a ausência de viés departamental ou político. Talvez aí resida a maior alavancagem que o uso do consultor externo possa ter, o de ser o catalisador desta transformação, considerando e conciliando demandas, muitas das vezes concorrentes.

\section{Recomendações à Prática}

Dada a difusão da importância de adoção de processos de melhoria contínua (Shah \& Ward, 2003; Voss, 2005; (Netland, 2013), a importância da capacitação para concretizar esforços de mlehoria contínua (García-Sabater, Marín-García e Perelló-Marín, 2012) e ao desapontamento obtido com boa parte das iniciativas de excelência operacional (Pay, 2008) recomenda-se a adoção de utilização de um modelo de análise de prontidão antes de iniciar o estágio de capacitação profissional. Este modelo funcionaria como um diagnóstico onde se checa aspectos facilitadores ou inibidores ligados a cada um dos aspectos altamente e moderadamente relevantes. $\mathrm{O}$ intuito é de identificar, o mais cedo possível, potenciais lacunas que possam inibir a transformação dos profissionais em agentes internos que continuem a implantar projetos de melhoria de forma sistemática e estruturada para obter melhoria de desempenho operacional de firma sustentável. Um exemplo desta análise de prontidão é apresentado nos Quadros 25.1 e 25.2 
A realização deste diagnóstico por um consultor externo é recomendada para que seja mantida a maior imparcialidade possível na identificação de obstáculos e resulte na recomendação de um processo de intervenção adaptado ao contexto organizacional, onde o consultor externo atua como um catalisador deste esforço de transformação dos profissionais em agentes internos de melhoria. Ao mesmo tempo, este referencial tem um alto valor aos profissionais da organização, no sentido de fornecer uma base comum de reflexão sobre qual o nível de prontidão atual e na decisão em conjunto com o consultor externo sobre qual caminho seguir nas ações de capacitação dos seus profissionais.

Adicionalmente os gestores e coordenadores de melhoria contínua poderiam revisar sua jornada de melhoria contínua a partir dos elementos identificados como relevantes. A alta direção deveria considerar seriamente a integração de todos os programas com o cunho de melhoria existentes num modelo unificado de maturidade de melhoria contínua. Também deveria estabelecer princípios ligados melhoria contínua e considerá-los como valores essenciais da organização, materializando estes princípios através da melhoria do nível de maturidade.

Quadro 25.1 - Modelo de análise de prontidão baseado nos elementos altamente relevantes a transformação de profissionais em agentes internos de melhoria.

\begin{tabular}{|l|l|l|l|}
\hline $\begin{array}{l}\text { Elementos } \\
\text { altamente } \\
\text { relevantes }\end{array}$ & $\begin{array}{l}\text { Fatores Facilitadores: } \\
\text { Características atuais } \\
\text { do contexto } \\
\text { organizacional } \\
\text { favoráveis ao } \\
\text { elemento }\end{array}$ & $\begin{array}{l}\text { Fatores Inibidores: } \\
\text { Características atuais } \\
\text { do contexto } \\
\text { organizacional } \\
\text { contrárias ao } \\
\text { elemento }\end{array}$ & $\begin{array}{l}\text { Ações necessárias para a } \\
\text { transformação efetiva dos } \\
\text { profissionais em agentes } \\
\text { internos de melhoria }\end{array}$ \\
\hline P1 & & & \\
\hline P2 & & & \\
\hline P3 & & & \\
\hline P6 & & & \\
\hline P8 & & & \\
\hline P15 & & & \\
\hline
\end{tabular}

Fonte: elaborado pelo autor. 
Quadro 25.2 - Modelo de análise de prontidão baseado nos elementos moderadamente relevantes a transformação de profissionais em agentes internos de melhoria.

\begin{tabular}{|l|l|l|l|}
\hline $\begin{array}{l}\text { Elementos } \\
\text { moderadamente } \\
\text { relevantes }\end{array}$ & $\begin{array}{l}\text { Fatores Facilitadores: } \\
\text { Características atuais } \\
\text { do contexto } \\
\text { organizacional } \\
\text { favoráveis ao } \\
\text { elemento }\end{array}$ & $\begin{array}{l}\text { Fatores Inibidores: } \\
\text { Características atuais } \\
\text { do contexto } \\
\text { organizacional } \\
\text { contrárias ao } \\
\text { elemento }\end{array}$ & $\begin{array}{l}\text { Ações necessárias para a } \\
\text { transformação efetiva dos } \\
\text { profissionais em agentes } \\
\text { internos de melhoria }\end{array}$ \\
\hline P4 & & & \\
\hline P5 & & & \\
\hline P7 & & & \\
\hline P9 & & & \\
\hline P10 & & & \\
\hline P13 & & & \\
\hline P14 & & & \\
\hline
\end{tabular}

Fonte: elaborado pelo autor.

\section{Recomendações à Teoria}

Também são importantes as seguintes recomendações com intuito de fortalecer e desenvolver a teoria administrativa ligada a melhoria contínua: introduzir o tema transformação de agentes internos de melhoria nas pesquisas sobre melhoria contínua, reorganizar os achados das pesquisas existentes em torno dos eixos de institucionalização e de agência humana.

A partir dos achados da pesquisa de campo não ligados diretamente as proposições teóricas, identificados no Quadro 24, puderam ser formuladas novas proposições teóricas. Estas proposições deveriam serem investigadas em futuras pesquisas e desta forma acrescentar conhecimento na teoria administrativa.

\section{Limites}

A pesquisa contou com a análise de campo de apenas representantes da indústria automobilística brasileira e em projetos de melhoria na área de operações. Os elementos revelados como relevantes aqui podem não ser aplicáveis ou necessitarem de ajustes para 
outras indústrias ou outros processos. Os três casos também podem não ser representativos de todas as montadoras

Outra limitação é que o escopo da pesquisa não foi o da melhoria contínua como um todo, mas revelar elementos relevantes para transformação de profissionais em agentes internos de melhoria.

Pesquisas futuras do tipo levantamento com as demais montadoras brasileiras que promovem processos de capacitação profissional visando a elaboração de projetos de melhoria poderiam ser realizadas para confirmar os elementos considerados relevantes, já que este estudo tem o caráter exploratório.

\section{Contribuições}

A grande contribuição é revelar a importância de conciliação de elementos de institucionalização da melhoria com elementos pessoais de agência humana e assim formar um referencial mais robusto, com presença de fatores sociais, técnicos, organizacionais e individuais, para a concretização de melhoria de desempenho através dos projetos conduzidos pelos agentes internos de melhoria. 


\section{REFERÊNCIAS}

Aloini, D., Martini, A., Pellegrini, L. (2011). Effectiveness of different development paths in continuous improvement: empirical results from a (new) methodological approach. International Journal of Technology Management, v. 55, n. 1-2, pp. 6-27, 2011. doi: 10.1504/IJTM.2011.041677.

Argyris C. (2003). A life full of learning. Organization Studies, v. 24(7): pp. 1178-1192. doi:10.1177/01708406030247009

Bandura, A. (2005). The evolution of social cognitive theory. In: Smith, K.G.; Hitt, M.A. Great minds in management, pp9-35. Oxford University Press.

Bessant, J., Caffyn, S., \& Gallagher, M. (2001). An evolutionary model of continuous improvement behaviour. Technovation, 21(2), pp. 67-77. doi: 10.1016/S0166-4972(00)000237

Bessant, J., Caffyn, S., Gilbert, J., Harding, R., \& Webb, S. (1994). Rediscovering continuous improvement. Technovation, 14(1), pp. 17-29. doi: 10.1016/0166-4972(94)90067-1.

Bessant, J., \& Francis, D. (1999). Developing strategic continuous improvement capability. International Journal of Operations \& Production Management, 19(11), 1106-1119. doi: $10.1108 / 01443579910291032$

Choo, A.S.,Linderman, K.W., Schroeder, R.G. (2007). Method and context perspectives on learning and knowledge creation in quality management. Journal of Operations Management, 25 (4), pp. 918-931

Eisenhardt, K. (1989). Building Theories from Case Study Research. The Academy of Management Review, 14(4), pp. 532-550. Retrieved from http://www.jstor.org/stable/258557

Fryer, K., Ogden, S., \& Anthony, J. (2013). Bessant's continuous improvement model: Revisiting and revising. International Journal of Public Sector Management,26(6), pp. 481494. Doi: 10.1108/IJPSM-05-2012-0052 
Garcia-Sabater, J. J., Marin-Garcia, J. A. and Perello-Marin, M. R. (2012), Is implementation of continuous improvement possible? An evolutionary model of enablers and inhibitors. Human Factors and Ergonomics in Manufacturing \& Service Industries, 22, pp. 99-112. doi:10.1002/hfm.20262

Glover, W. J., Farris, J. A., \& Van Aken, E.,M. (2015). The relationship between continuous improvement and rapid improvement sustainability. International Journal of Production Research, 53(13), pp. 4068-4086. doi:http://dx.doi.org/10.1080/00207543.2014.991841

Godoy, A. S. (1995). Introdução à Pesquisa Qualitativa e suas Possibilidades. RAE-Revista de Administração de Empresas, 35(2), pp. 57-63.

Gonzalez, R. V. D., \& Martins, M. F. (2015). Continuous improvement enabling competences: case studies in companies in the automotive sector and capital goods. Gestão \& Produção, 22(4), pp. 725-742. doi: 10.1590/0104-530X1017-13

Huang, X., Rode, J., \& Schroeder, R. (2011). Organizational structure and continuous improvement and learning: Moderating effects of cultural endorsement of participative leadership. Journal of International Business Studies, 42(9), 1103-1120. Retrieved from http://www.jstor.org/stable/41309753

Hyland, P. W., Mellor, R., \& Sloan, T. (2007). Performance measurement and continuous improvement: Are they linked to manufacturing strategy?. International Journal of Technology Management, 37(3), pp. 237-246. doi: 10.1504/IJTM.2007.012260

Kornfeld, B. J., \& Kara, S. (2011). Project portfolio selection in continuous improvement. International Journal of Operations and Production Management, 31(10), 1071-1088. doi: 10.1108/01443571111172435.

Lam, M., O’Donnell, M., \& Robertson, D. (2015). Achieving employee commitment for continuous improvement initiatives. International Journal of Operations \& Production Management, 35(2), pp. 201-215. doi:10.1108/IJOPM-03-2013-0134.

Martin-Alcazar, F., Romero-Fernandes, P.M., \& Sanchez-Gardey, G. (2005). Strategic human resource management: integrating the universalistic, contingent, configurational and contextual perspectives. International Journal of Human Resource Management, vol. 16, no.5, pp.633-59. 
McLean, R., \& Antony, J. (2014). Why continuous improvement initiatives fail in manufacturing environments? A systematic review of the evidence. International Journal of Productivity and Performance Management, 63(3), pp. 370-376. doi: 10.1108/IJPPM-072013-0124.

Netland, T. (2013). Exploring the Phenomenon of Company-Specific Production Systems: One-best-way or Own-best-way?, International Journal of Production Research, v. 51 (4), pp. 1084-1097. doi:10.1080/00207543.2012.676686

Netland, T., \& Aspelund, A. (2014). Multi-plant improvement programmes: A literature review and research agenda. International Journal of Operations \& Production Management, 34(3), pp. 390-418. doi: 10.1108/ijopm-02-2012-0087.

Oprime, P. C., Mendes, G. S., \& Pimenta, M. L. (2012). Continuous improvement: Critical factors in brazilian industrial companies. International Journal of Productivity and Performance Management, 61(1), pp. 69-92. doi: 10.1108/17410401211187516

Pay, R. (2008). Everybody's jumping on the lean bandwagon, but many are being taken for a ride. Industry Week; March 05, 2008.

Peng, D. X, Schroeder, R. G, \& Shah, R.(2008). Linking routines to operations capabilities: A new perspective. Journal of Operations Management, v. 26, n. 6, pp. 730-748. doi: 10.1016/j.jom.2007.11.001

Salah, S. (2015). A project selection, prioritisation and classification approach for organisations managing continuous improvement (CI). International Journal of Project Organisation and Management, 7(1), pp. 98-110. doi: 10.1504/IJPOM.2015.068006

Sanchez, L., Blanco, B. (2014). Three decades of continuous improvement. Total Quality Management \& Business Excellence, v. 25, n. 9-10, pp. 986-1001. doi: $10.1080 / 14783363.2013 .856547$

Shah, R., Ward, P. T.(2003). Lean manufacturing: context, practice bundles and performance. Journal of Operations Management, v. 21, n. 2, pp. 129-149. doi: 10.1016/S02726963(02)00108-0 
Schein, E. H. (2010). Organizational Culture and Leadership, 4th Ed. San Francisco: JosseyBass.

Sousa, R., \& Voss, C. A. (2008). Contingency research in operations management practices. Journal of Operations Management, v. 26, n. 6, pp. 697-713.

Strauss, A.; \& Corbin, J. (2008). Pesquisa qualitativa: técnicas e procedimentos para o desenvolvimento de teoria fundamentada. 2. ed. Porto Alegre: Artmed, 288p. (Série Métodos de Pesquisa).

Torres Jr., A. S., Gati, A. M. (2011). Identification of Barriers Towards Change and Proposal to Institutionalize Continuous Improvement Programs in Manufacturing Operations. Journal of Technology Management \& Innovation, v. 6, n. 2, p. 94-109. doi: 10.4067/S071827242011000200007

Voss, C.A. (2005). Paradigms of manufacturing strategy re-visited. International Journal of Operations \& Production Management, 25(12), pp. 1223-1227. doi: 10.1108/01443570510633620.

Yen-Tsang, C., Csillag, J. M., Siegler, J. (2012). Theory of reasoned action for continuous improvement capabilities: a behavioral approach. RAE-Revista de Administração de Empresas, 52(5), 546-564. doi:10.1590/S0034-75902012000500006

Yin, R. K. (2010). Estudo de caso: planejamento e métodos. $4^{\mathrm{a}}$ Edição. Porto Alegre: Bookman.

Wenbin, N., Hongyi S. (2009). The relationship among organisational learning, continuous improvement and performance improvement: An evolutionary perspective. Total Quality Management \& Business Excellence, v. 20 (10), pp. 1041-1054. doi: $10.1080 / 14783360903247312$

Wu, C. \& Chen, C. (2006). An integrated structural model toward succesfull continuous improvement activity. Technovation, v.26 (n.5-6), pp. 697-707. doi: 10.1016/j.technovation.2005.05.002 


\begin{abstract}
APÊNDICES
APÊNDICE 1 - Lista das assertivas elaboradas a partir do referencial teórico

APÊNDICE 2 - Informações e Declarações oriundas das entrevistas da Montadora A

APÊNDICE 3 - Informações e Declarações oriundas das entrevistas da Montadora B

APÊNDICE 4 - Informações e Declarações oriundas das entrevistas da Montadora C
\end{abstract}

APÊNDICE 5 - Documentos analisados na Montadora A

APÊNDICE 6 - Documentos analisados na Montadora B

APÊNDICE 7 - Documentos analisados na Montadora C 
APÊNDICE 1 - Lista das assertivas elaboradas a partir do referencial teórico

Abaixo estão apresentadas as 46 assertivas oriundas do referencial teórico.

\begin{tabular}{|l|l|}
\hline AS1 & $\begin{array}{l}\text { É necessário uma motivação e crença genuína, por parte dos gestores e alta direção, } \\
\text { de que a transformação dos profissionais em agentes internos é relevante para a } \\
\text { melhoria do desempenho organizacional. }\end{array}$ \\
\hline
\end{tabular}

\begin{tabular}{|l|l|}
\hline AS2 & É necessário um suporte gerencial a realização de projetos de melhoria, o que \\
implica em altos níveis de envolvimento alocação de tempo do gestor para liderar a \\
mudança. Exemplo disso é a comunicação face-a-face e visitas regulares dos \\
gestores na fábrica para acompanhar as rotinas de trabalho.
\end{tabular}

\begin{tabular}{|l|l|}
\hline AS3 & $\begin{array}{l}\text { É necessário considerar o nível organizacional em que estão situados a primeira } \\
\text { leva de profissionais a serem capacitados e o tipo e velocidade de desdobramento } \\
\text { para os demais níveis organizacionais, aumentando o grau de participação dos } \\
\text { membros da organização. }\end{array}$ \\
\hline
\end{tabular}

\begin{tabular}{|l|l|}
\hline AS4 & $\begin{array}{l}\text { É necessário o comprometimento gerencial não apenas com a capacitação, mas } \\
\text { também com o método de implantação. }\end{array}$ \\
\hline
\end{tabular}

\begin{tabular}{|l|l|}
\hline AS5 & É necessário prever e prover a integração das metodologias de solução de \\
& problemas e ferramentas fundamentais e avançadas da qualidade, ensinadas aos \\
& agentes, com os processos organizacionais existentes.
\end{tabular}

\begin{tabular}{|l|l|}
\hline AS6 & $\begin{array}{l}\text { É necessário a escolha cuidadosa das pessoas com função de coordenação da } \\
\text { iniciativa de melhoria contínua. }\end{array}$ \\
\hline
\end{tabular}

\begin{tabular}{|l|l|}
\hline AS7 & É necessário a escolha adequada de abordagem de aprendizagem e aplicação \\
prática dos conteúdos, que devem ser técnicos e comportamentais, trabalhados \\
durante o treinamento dos agentes internos.
\end{tabular}




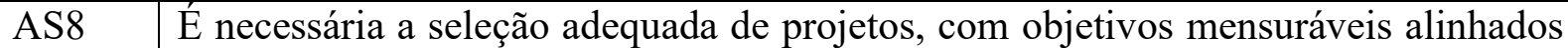
com a estratégia organizacional.

\begin{tabular}{|l|l|}
\hline AS9 & É necessário que os projetos de melhoria conduzidos pelos agentes internos contem
\end{tabular} com a participação ativa da equipe de projeto e suporte de mentores aos agentes internos.

\begin{tabular}{|l|l|}
\hline AS10 & É necessário a resolução de conflito e acúmulo de papéis dos agentes internos, o
\end{tabular} que significa que os agentes internos devem ter desenvolvidas as habilidades de gerenciamento de conflitos, gerenciamento de tempo e delegação.

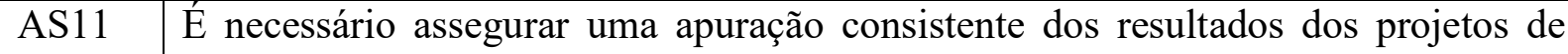
melhoria, incluindo a verificação do estabelecimento eficaz de novos padrões de trabalho.

\begin{tabular}{|l|l|}
\hline AS12 & $\begin{array}{l}\text { É necessário assegurar uma comunicação efetiva dos resultados dos projetos dentro } \\
\text { da organização. Para ser efetiva a comunicação deve ser realizada em todos os } \\
\text { níveis, com linguagem e frequência apropriadas. }\end{array}$ \\
\hline
\end{tabular}

AS13 É necessário monitorar a percepção sobre a eficácia dos projetos de melhoria, de forma a prevenir e corrigir percepções de fracasso da transformação dos agentes internos.

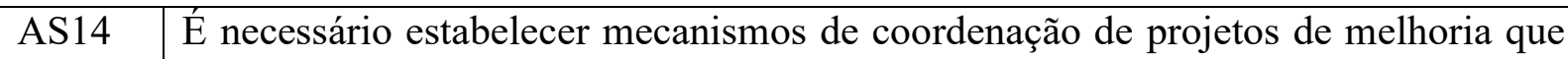
ocorrem concomitantemente, em especial, quanto ao alinhamento de objetivos e ao uso de recursos comuns e escassos.

AS15 $\quad$ É necessário a existência de planos de sugestão visando a participação dos colaboradores na melhoria do processo produtivo.

AS16 $\quad$ É necessário a existência de um sistema de incentivos, não necessariamente 


\begin{tabular}{|l|l|l}
\hline financeiro, para que os profissionais tornem=se motivados com a sua \\
transformação em agentes internos de melhoria.
\end{tabular}

\begin{tabular}{|l|l|}
\hline AS17 & É necessário a realização de reuniões regulares entre os agentes de melhoria,
\end{tabular} operários e líderes.

\begin{tabular}{|l|l|}
\hline AS18 & É necessário assegurar a estabilidade dos equipamentos para que os projetos de
\end{tabular} melhoria realizados pelos agentes internos tenham resultados sustentáveis.

AS19 $\quad$ É necessário que o coordenador de melhoria seja um profissional em tempo integral para realização, apoio e coordenação dos diversos projetos de melhoria.

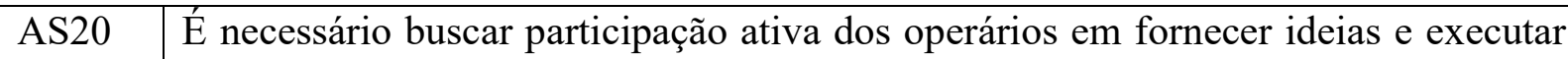
as melhorias propostas, com cuidado especial a comunicação clara para afastar o medo de perda de emprego em função das melhorias.

\begin{tabular}{l|l} 
AS21 & É necessário a seleção times de trabalho multidisciplinares em projetos de melhoria
\end{tabular} que visam resolver problemas que permeiam diversos departamentos funcionais.

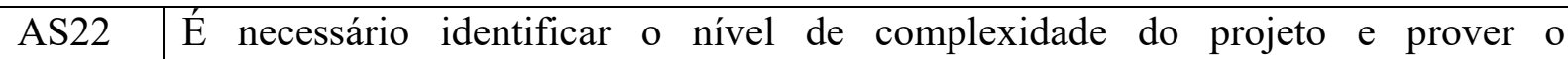
conhecimento de ferramentas em função desta complexidade.

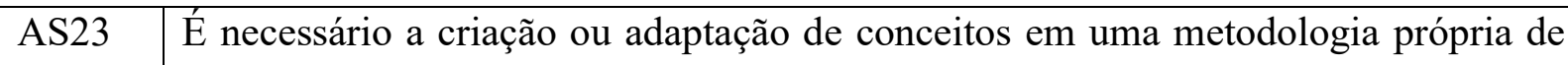
melhoria e modelo de excelência em operações.

\begin{tabular}{|l|l|}
\hline AS24 & É necessário atingir sucesso com os projetos iniciais, solucionando de problemas
\end{tabular} significativos sob a ótica da direção, e, desta forma, gerando um ciclo virtuoso de apoio gerencial a realização de novos projetos de melhoria.

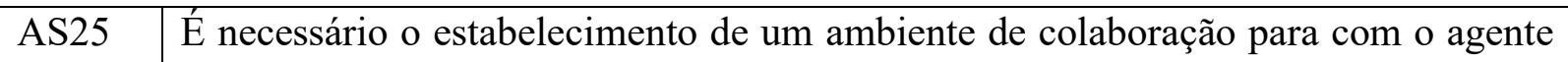
interno, para que as informações necessárias a realização do projeto de melhoria 
possam fluir com maior rapidez e acuracidade.

\begin{tabular}{|l|l|}
\hline AS26 & É necessário um processo de gestão do conhecimento efetivo, capaz de resgatar e
\end{tabular} utilizar o conhecimento gerado em projetos anteriores.

\begin{tabular}{l|l} 
AS27 & É necessário que o agente interno de melhoria entenda as metas organizacionais.
\end{tabular}

\begin{tabular}{l|l}
\hline AS28 & É necessário que o agente interno de melhoria possua autonomia para realizar as
\end{tabular} atividades requeridas pelo projeto de melhoria.

AS29 $\quad$ É necessário que o estabelecimento de um ambiente de colaboração entre os agentes internos de melhoria.

AS30 $\quad$ É necessário o estabelecimento de um canal de comunicação com os agentes internos de melhoria que responda a seus questionamentos e consultas.

AS31 $\quad$ É necessário o uso de táticas de influência pelos gestores, incluindo apelos racionais e de inspiração.

AS32 É necessário selecionar projetos que otimizem continuamente o estado futuro, ou seja, parta das melhorias já alcançadas e promova a melhoria de desempenho, como uma extensão das melhorias alcançadas.

\begin{tabular}{|l|l|}
\hline AS33 & $\begin{array}{l}\text { É necessário estabelecer um gerenciamento do portfólio de projetos, visando } \\
\text { integração e maior grau de impacto em áreas prioritárias oriundas da estratégia de } \\
\text { operações. }\end{array}$ \\
\hline
\end{tabular}

AS34 É necessário estabelecer, desde a fase de seleção inicial de projetos, a escolha de métricas adequadas para julgamento dos resultados a serem alcançados.

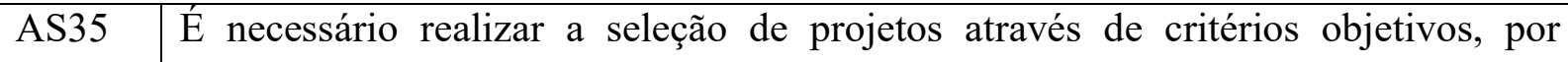


exemplo através do uso de uma matriz de seleção e priorização de projetos.

\begin{tabular}{l|l} 
AS36 & É necessário a promoção da aceitação a mudança, ou seja, instigar nos agentes
\end{tabular} internos e em seus gestores o questionamento e modificação de procedimentos ou práticas enraizadas na busca de melhorias.

AS37 $\quad$ É necessário a promoção de um senso compartilhado de responsabilidade e contribuição para com outras áreas, não só as de atuação do agente interno.

\begin{tabular}{|l|l|}
\hline AS38 & É necessário a adoção de um modelo de maturidade para formar e fortalecer uma
\end{tabular} cultura de melhoria contínua que incentive os agentes internos a dar continuidade dos projetos atuais e realizar novos projetos de melhoria.

AS39 É necessário tornar a melhoria contínua parte da rotina diária dos agentes internos.

\begin{tabular}{|l|l}
\hline AS40 & É necessário estabelecer a melhoria do processo de melhoria contínua.
\end{tabular}

\begin{tabular}{|l|l|}
\hline AS41 & É necessário remover a cultura da busca aos culpados pelos problemas, para que os
\end{tabular} projetos sejam objetivos e não adotes viés politizado.

AS42 $\quad$ É necessário que cada agente interno de melhoria tenha uma atitude favorável em relação a dar continuidade aos projetos atuais e iniciar novos projetos de melhoria.

\begin{tabular}{|l|l|}
\hline AS43 & É necessário o estabelecimento de uma normalização para os agentes internos que
\end{tabular} requeira a continuidade dos projetos atuais e iniciar novos projetos de melhoria.

AS44 $\quad$ É necessário que os agentes internos tenham uma percepção de auto eficácia ao possuir a competência para realizar projetos de melhoria.

AS45 $\quad$ É necessário que haja a paciência gerencial e dos próprios agentes com a colheita dos resultados dos projetos de melhoria. 
AS46 $\quad$ É necessário o fomento de uma cultura de trabalho em equipe e autonomia, já que o contexto cultural brasileiro não favorece a liderança participativa ou a autonomia para iniciativa. 
APÊNDICE 2 - Informações e Declarações oriundas das entrevistas da Montadora A

Abaixo estão apresentadas as declarações mais relevantes oriundas das entrevistas nas montadoras A, na forma de extratos das principais afirmações coletadas durante as entrevistas. As declarações são descritas entre aspas, em itálico e com espaçamento entre linhas simples. Os temas destas declarações são colocados acima e funcionam como um sumário principal inferido a partir das declarações.

Foram entrevistados: o coordenador de melhoria contínua, um gestor e três agentes internos de melhoria.

1.1) Entrevista junto ao coordenador de melhoria da Montadora A

As respostas em relação as assertivas do roteiro de entrevista estão descritas abaixo: Reposta sobre a expectativa de continuidade dos projetos: "7 - Concordo Fortemente"

"É esperado que, após a conclusão de sua capacitação, cada profissional passe a identificar e realizar projetos de melhoria para atingir objetivos de desempenho e resolver problemas crônicos, transformando-se num efetivo agente interno de melhoria contínua."

Resposta sobre a realidade de continuidade de projetos: " 2 - Discordo"

"Os agentes internos capacitados continuaram a implantar projetos de melhoria de forma sistemática, mesmo após o término da capacitação inicial. ”

Abaixo estão descritos os principais temas relatados pelo coordenador de melhoria contínua, que atua há mais de 16 anos na área de qualidade da montadora $\mathrm{A}$ e é pós-graduado.

w) Contratação da consultoria teve o propósito de ajudar na coordenação e suporte aos projetos dos agentes internos durante a capacitação inicial.

"Inicialmente treinamos e desenvolvemos a atividade de melhoria e o pessoal internamente, ganhando know how. Daí o programa cresceu tanto que não podíamos dar conta sozinho, sendo melhor contratar uma empresa e que tivesse a coordenação e suporte aos projetos dos 
agentes internos. A consultoria tinha liberdade de fazer melhoria no treinamento e o consultor deveria ter conhecimento na metodologia e também conhecimento de processo produtivo."

x) O consultor deve compreender questões políticas e rotina da empresa.

"A consultoria deve entender a política e a forma de trabalhar da empresa, ser mais aberta quanto a rigidez de uso de ferramentas porque os agentes estão aprendendo e se o projeto inicial for demasiadamente criticado, eles começam a perder o interesse."

y) O ideal: agente interno como agente transformador.

"Se todos fossem agentes transformadores a empresa seria outra empresa em melhoria de processo."

z) O agente deve saber utilizar de forma apropriada, e não apenas burocrática, as ferramentas.

"Não é necessário usar sempre toda a metodologia, e sim a utilização apropriada as ferramentas."

aa) Existem pessoas que adotaram para si o papel de agente, e se não encontraram espaço para aplicar a melhoria, saíram e foram para outras empresas para tal.

“As pessoas que adotaram para si, ganharam o reconhecimento e são pessoas diferenciadas. Muitos saírem saíram e foram para outras empresas para ser agente transformador."

bb) Resultados iniciais satisfatórios, porém, com baixo índice de transformação de profissionais em agentes internos de melhoria.

"Ao longo de quase uma década de programa de melhoria, aproximadamente 70\% concluíram o projeto inicial (ponto positivo pois dá resultado para o programa). Nos primeiros dois anos tivemos $40 \%$ de continuidade. Mas no final de 10 a 20\% como agente transformador." 
cc) Alta direção não precisa de conhecimento aprofundado nas ferramentas, mas precisa acreditar e não ser imediatista na solução de problemas.

"A alta direção não precisa ser atuante a nível de conhecimento total, mas precisa acreditar na qualidade fica mais fácil para fazer trabalho de melhoria, pois encara extremamente importante em melhorar o produto. Quando a alta direção não tem conceitos fortes de qualidade, porque é imediatista, só acredita naquilo que mostra. Exemplo: caneta faltando a tampa, para ele a causa é a falta da tampa, e não tem conceito na causa raiz, para ele colocar uma pessoa colocando a tampa (retrabalho) tá bom."

dd) Na Montadora A é preciso convencer cada gestor. Na Montadora C, ao convencer o diretor de planta, todos seguem as suas diretrizes.

"O diretor de qualidade começou a puxar a melhoria, mas precisávamos da alta direção das plantas e aí foi a diferença. Exemplo: $\mathrm{Na}$ Montadora $\mathrm{C}$ foi muito difícil no começo, mas por causa da mudança do diretor de planta a coisa ficou muito mais fácil por lá. A Montadora A é mais difícil, é muito grande, cada departamento é um mundo diferente. Na Montadora $\mathrm{C}$, tudo converge e precisa convencer um local só, na Montadora A é preciso convencer cada gestor departamental. A alta direção na montadora A é boa em finanças e tecnicamente, mas não acredita em aplicação de metodologia para melhoria da qualidade. ”

ee) Coordenador deve conhecer profundamente a metodologia e ter habilidades políticas.

"Coordenador precisa conhecer a fundo o tema, deve ser um expert que conheça a fundo. $\mathrm{O}$ coordenador precisa as vezes ser político, não pode radicalizar com consultoria, com o agente e gestor, para criar um ambiente produtivo. Exemplo: uma turma de 10 engenheiros veteranos com grande status junto a gestão pegou um consultor sem flexibilidade. Eles começaram a falar mal do assunto, e nem queriam fazer o treinamento. Tive que conversar de forma firme com engenheiros, e peguei o exemplo de 1 dos 10 que fechou o projeto e usamos o caso para mostrar que era possível. Reverteu-se a situação e 7 concluíram o projeto e fizeram o $2^{\circ}$ projeto."

ff) Nem sempre um profissional experiente é um bom agente interno. 
"Um dos engenheiros era um veterano e o próprio gestor cancelou o projeto dele, inclusive foi pedido que ele pagasse o valor do treinamento (uma pessoa com alto nível de escolaridade, com mestrado, mas teve uma atuação complicada). "

gg) O gestor deve liderar o caminho, estabelecendo metas desafiadoras e apoiando a condução do projeto.

"Papel importantíssimo e de alta influência na qualidade dos projetos. Exemplo: um dos gestores que foi um dos primeiros a fazer a capacitação, discutia com a equipe dele a meta de reduzir 70\% de uma perda porque ele sabia que é possível e queria que eles atingissem isso, o que faria eles acreditarem na metodologia. Ele ajudava, não só pedia, pois ia pessoalmente no início de cada reunião entre áreas. "

hh) $\mathrm{O}$ gestor deve quebrar as barreiras departamentais para que o projeto possa fluir.

“É importante o gestor quebrar as barreiras entre áreas, o projeto na maioria das vezes permeia várias áreas, e no fundo eles estão sendo treinados em gestores de projetos multi departamentais. Sem o gestor o agente não muda as questões interdepartamentais. "

ii) A grande dificuldade do agente é transformar seu tema em prioridade para outras áreas.

“A grande dificuldade do agente é transformar o tema como prioridade em outras áreas e daí entra o gestor, daí o trabalho anda legal."

jj) Profissionais experientes que aprenderam a resolver problemas sem a metodologia são mais resistentes a aplicar projetos de melhoria de forma estruturada. O gestor deve mapear e atuar próximo a estes casos.

"Pessoas mais experientes que não usaram as ferramentas ao longo de sua trajetória profissional tem uma grande dificuldade de aceitar o uso de metodologia. Alguns até ficam pulverizando o mal humor dele para os outros, daí o gestor deve mapear estes casos e trabalhar próximo delas. 
Os resistentes arranjam um monte de desculpas sobre o porquê deve parar o projeto, especialmente se o gestor não conhece o tema e a metodologia. No início fazíamos um trabalho de mapeamento de mudança e comentava com gestor o que deveria ser trabalhado. Quando ele não trabalhava no meio do projeto travava mesmo, era muito previsível."

kk) A consultoria deveria fazer um trabalho de mudança atitudinal, tornando as pessoas mais favoráveis a realização de projetos de melhoria.

"A atitude pessoal de mudança é fundamental. Todo programa de melhoria deveria ter um trabalho de "convencimento e mudança de atitude: citando custos, benefícios, expectativas" para enxergar melhor o programa. Isso deveria ter sido feito melhor pela consultoria.”

11) RH e Controladoria são funções de suporte que deveriam ser envolvidas no programa.

“Esqueci do RH porque ele não participou. O controler também é importante. $\mathrm{O}$ RH poderia contribuir das transformações de mudança na empresa alinhando os resultados do programa com plano de carreira e daí as pessoas enxergariam a oportunidade de crescimento na empresa, deveria contar pontos no final.

Já o controler fazer do programa a parte financeira para mostrar com o programa se paga. Ter um sisteminha para entrada de dados e seu objetivo é sempre melhoria e redução de custo no final. Cada planta (Montadora A e C) tem o seu controler. Chegou-se a fazer uma turma com a presença do controler e foi fantástico, mas depois não deu continuidade. “

mm) Os resultados de uma década do programa comprovam seu benefício.

“1302 pessoas treinadas 762 certificadas. Redução de custo e perdas com a implantação dos projetos foi de $\mathrm{R} \$ 57$, para um investimento de $\mathrm{R} \$ 2,5$ milhões em treinamento e consultoria."

nn) A atitude favorável do agente interno é fundamental para a continuidade de novos projetos de melhoria.

"A atitude pessoal é fundamental, conseguindo entender que a metodologia é boa para ele (conciliar com o dia a dia e ver oportunidades com tudo isso. Exemplo: um inspetor queria fazer treinamentos em ferramentas avançadas de solução de problema e começou a ajudar os 
colegas a terminarem seus projetos. Isto foi em 2 projetos apresentados para direção, mudou da qualidade (inspetor) e se transformou num analista da qualidade e foi para engenharia de produto (sonho dele) e hoje lá já fez trabalho com protótipos melhorando os processos de engenharia, e ainda continua usando a metodologia."

oo) O coordenador deve ter habilidades de negociação e influência.

No início o coordenador de melhoria da Montadora $\mathrm{C}$ era radical e fomos trabalhando a parte comportamental com diálogos e troca de experiências, para mostrar que nas grandes empresas não é do nosso jeito e sim buscar a entender pessoas diferentes dele e chegar ao meio termo. O coordenador não pode ser radical e deve focar na capacitação do maior número possível de pessoas.

pp) $\mathrm{O}$ orçamento do programa de capacitação não pode estar alocado na função qualidade e sim no RH.

“O programa estava alocado no lugar errado estava dentro da qualidade. Não estava dentro do RH. O programa deveria estar dentro do RH que tem o budget para isso. A crise econômica de 2015 e 2016 fez a direção da qualidade perguntar: O que estamos gastando? Daí o apoio ao processo de capacitação dos agentes morreu, porque foi identificado como core o treinamento para o budget do RH.”

qq) A controladoria deve avaliar os resultados dos projetos de forma independente, senão em momentos de crise não se mantém a estrutura do programa.

“A falta do controler na validação dos resultados dos projetos, associada a várias reduções de custo em função do contexto recessivo desde 2015 fez com que o orçamento para capacitação de novos agentes fosse eliminado e a própria estrutura de coordenação alocada em outras áreas, fazendo com que o programa de mais de uma década perdesse boa parte de sua força."

rr) Reduções de custo sem visão sistêmica de seu impacto no longo prazo minaram a estrutura do programa. 
"Na crise houve troca de gestores, presidente e diretor e entrou uma turma nova com enfoque para reduzir gastos. O que vai acontecer? Já estamos sentindo que as pessoas certificadas não praticam novos projetos. Acredito que muitos não estão fazendo novos projetos para não chamar a responsabilidade para si e ouço justificativas do tipo: - Antigamente trabalhávamos assim, mas vocês cancelaram tudo por isso estamos vivendo isso, infelizmente. Eu mesmo não coordeno este processo extinto e fui realocado para outra área. O fogo é que vai ter de recomeçar tudo de novo, tomara que comece alocado no lugar certo. “

\section{2) Entrevista junto a um gestor da Montadora $A$}

As respostas em relação as assertivas do roteiro de entrevista estão descritas abaixo:

Reposta sobre a expectativa de continuidade dos projetos: "7 - Concordo Fortemente"

"É esperado que, após a conclusão de sua capacitação, cada profissional passe a identificar e realizar projetos de melhoria para atingir objetivos de desempenho e resolver problemas crônicos, transformando-se num efetivo agente interno de melhoria contínua."

Resposta sobre a realidade de continuidade de projetos: " 1 - Discordo fortemente" "Os agentes internos capacitados continuaram a implantar projetos de melhoria de forma sistemática, mesmo após o término da capacitação inicial."

Abaixo estão descritos os principais temas relatados por um dos gestores, que atuou como supervisor na área de qualidade da Montadora A entre 2008 a 2015 e possui mestrado em metalurgia.

t) Contratação da consultoria teve o propósito fomentar o programa de melhoria.

"Contratou-se a consultoria para fomentar o programa de melhoria e formar massa crítica para solucionar problemas."

u) A alta direção deve comprar a filosofia de aplicação de metodologia estruturada para resolução de problemas. 
“O programa morreu no final de 2014. Pessoalmente apresentei ao diretor um projeto com ferramentas avançadas para resolver problemas complexos, mas ele era uma pessoa operacional. Se não tem um diretor que compre a metodologia não vai. Faltou o aporte da alta direção."

v) O gestor deve acompanhar semanalmente os projetos dos agentes de sua equipe.

"Uma reunião de apresentação semanal com o padrinho e o agente é fundamental para assegurar que o projeto está no rumo certo."

w) A alta direção deve fomentar os gestores a fomentarem projetos de melhoria.

"Espera-se que a alta direção tenha noção de como a metodologia contribui para o resultado financeiro do negócio agregando valor na redução de falhas e satisfação do cliente. Não precisa ser profundo detentor das ferramentas e técnicas. Precisa fomentar que os gestores fomentem."

x) A alta direção não pode aceitar soluções paliativas, que não ataquem a causa raiz.

“Aceitava-se soluções práticas sem um embasamento teórico robusto. Isto é um problema porque ocorrem soluções paliativas sem endereçar causa raiz, vai apenas navegando de problemas, porém o patamar de falhar continua, sem resolver definitivamente o problema."

y) A falta de tempo para se dedicar aos projetos acaba gerando soluções ineficazes e os problemas acabam recorrendo.

"O coordenador tem o papel teórico de trabalhar com o portfólio de projetos para promover melhorias. $\mathrm{Na}$ prática não ocorreu, porque muitos projetos resolviam problemas momentaneamente, 4 meses depois os problemas ocorriam de novo. No início, alguns agentes seguravam o problema com contenção só para se certificar. Isto ocorria porque os agentes não tinham tempo para não se dedicar adequadamente ao projeto e a gestão não entendia e provia suporte de tempo para endereçar definitivamente cada problema. Não ocorreu na maioria dos casos um amparo de tempo em todas as camadas." 
z) O coordenador melhoria e o seu gestor não tinha força junto a direção para exigir maior apoio de tempo dedicado para a realização dos projetos.

"O coordenador de fato não tinha força. O coordenador teórico era um gestor que não entrava direto na estrutura e tinha medo do estilo de gestão do diretor ou não conseguia convencê-lo. ,

aa) O nível de apoio dos gestores variava muito, e isto afeta significativamente o resultado dos projetos dos agentes de suas equipes.

"O nível de apoio dos gestores variava muito de gestor para gestor. Em algumas áreas o gestor apoiava os analistas a se dedicar a projetos e segurava a bronca do dia-a-dia, para que os analistas conseguissem desenvolver os projetos."

bb) Em áreas ligadas a solução de problemas, projetos de melhoria tem maiores chances de integração com a rotina.

"O gestor do centro técnico veicular, área de garantia que realmente tinha de utilizar ferramentas de análise. Na fábrica uma típica reunião com gestores era a seguinte: ' estamos com estes problemas, o que fizeram, contenção x, y, z; então está tudo ok'. "

cc) O gestor precisa conhecer a metodologia de solução de problemas.

"O gestor que conhecia a ferramenta aplicava e fomentava. É basicamente impossível que não conhece um assunto com boa profundidade fomentá-lo adequadamente. ”

dd) $\mathrm{O}$ agente interno deve acreditar nas ferramentas e metodologia, ter vontade de aprender, aprender e depois aplicar.

"Espera-se a dedicação aos projetos, acreditar no projeto e aplicar os conceitos. O agente deve acreditar na ferramenta e na metodologia, com vontade de aprender, aprender e depois aplicar." 
ee) $\mathrm{O}$ agente interno deve ter desenvolvida a capacidade analítica, conhecimento técnico do processo onde está realizando o projeto e ser um negociador.

"Capacidade analítica, negociar e analisar os dados, conhecimento técnico e de gestão de projetos, em determinados momentos terá de colocar pressão ou ceder. Exemplo: uma área não quer implantar uma lista de verificação para apontamento manual de dados necessários para o projeto. $\mathrm{O}$ agente então precisa influenciar e se não conseguir deve colocar pressão na escalada da pirâmide."

ff) $\mathrm{O}$ agente interno deve monitorar as ações de melhoria até que o novo método esteja enraizado.

"Quando a solução depende de mudança em atitude é preciso influenciar não só pelo convencimento e sim adicionar algum monitoramento. Por exemplo as vezes deve-se mudar a sequência de montagem anterior e o operador está acostumado há 3 meses e gerou um hábito que faz mais fácil e rápido. Para tirar este hábito, que as vezes impacta mais movimentação e tempo, mas no todo não é perda porque tem menos retrabalho. A tendência natural é voltar o método antigo, por isso é importante o próprio agente voltar para acompanhar os 3 turnos. É papel do agente monitorar até que o novo método esteja enraizado."

gg) A própria estrutura de trabalho da área deveria monitorar a implantação das melhorias, mas não faz isso devido a rotina ter inúmeras tarefas a serem feitas.

"O certo deveria ser o chefe internalizar e monitorar, mas na prática isso não ocorre nas montadoras. Um líder cuidando de 100 pessoas tem uma diversidade de problemas muito alta e não consegue dar foco, o agente sim porque está focado neste problema. Eu pessoalmente exigia isto dos meus agentes: você vai monitorar isso e depois eu pessoalmente escalava com o gestor da área."

hh) $\mathrm{O}$ alinhamento com a estratégica de negócio deveria ser direto, pois cada projeto deveria ser um projeto de interesse do CEO. 
"Cada agente deveria ter projetos que fossem considerados projeto do CEO."

ii) Se o gestor valorizar e apoiar, os agentes acabam realizando novos projetos.

"Se a chefia fomenta e acredita na metodologia os novos projetos são iniciados, mesmo após o término do treinamento. A minha área continuou aplicando os conceitos com a dosagem menor, porque eu fomentava."

jj) Quando o agende acredita que a metodologia de projetos de melhoria representa uma oportunidade de crescimento dentro ou fora da empresa, há maior chance de dar continuidade com novos projetos de melhoria.

"Se o agente acredita que pode utilizar a metodologia para crescer profissionalmente, seja na área ou mudando de área ou de empresa. Muitos acreditavam que era reconhecido no mercado como ferramenta de diferenciar sua empregabilidade."

kk) A necessidade de soluções rápidas e sua suficiência diante da grande variedade de problemas é um grande risco a construção de ações de melhoria robustas.

"A necessidade de soluções muito rápidas para os problemas, uma variedade muito grande de problemas, ou seja, não se trabalhava com o Pareto de principais problemas. ”

11) Na Montadora C, a aplicação da metodologia foi muito mais efetiva, devido o apoio do diretor de planta e o envolvimento além

"Na Montadora C, o diretor de planta fomentou com que todos os líderes de produção fossem treinados e era patente alta e ligada ao presidente. Lá fez a ferramenta viva, um ponto isolado no grupo."

1.3) Entrevista junto aos agentes internos de melhoria da Montadora A

As respostas em relação as assertivas do roteiro de entrevista estão descritas abaixo: 
Reposta sobre a própria continuidade dos projetos: "Analista A1: 7 - Concordo Fortemente, Analista A2: 1 -Discordo Fortemente, Analista A3: 6-Concordo"

"Eu continuo a implantar projetos de melhoria de forma sistemática, mesmo após o término da minha capacitação inicial. "

Resposta sobre a qualidade de apoio recebido para dar continuidade de projetos: "Analista A1: 4 - Neutro, Analista A2: 7 - Concordo Fortemente, Analista A3: 4-Neutro"

"O programa atualmente ainda depende dos agentes internos (como eu) para desencadear os projetos. Se eu não puxar as melhorias não acontecem. "

Resposta sobre a percepção do papel do agente interno como agente de transformação do programa de melhoria contínua: "Analista A1: 5 - Concordo levemente, Analista A2: 7 Concordo Fortemente, Analista A3: 7 - Concordo Fortemente"

O agente interno consegue transformar ou mudar o comportamento de outras pessoas e fazêlas ter iniciativa para melhoria contínua.

Abaixo estão descritos os principais temas relatados por três agentes, que atuam como analistas sênior da qualidade da Montadora A. O agente A1 trabalha no centro técnico de garantia e possui mestrado em qualidade. $\mathrm{O}$ agente $\mathrm{A} 2$ trabalha realizando auditoria de processo nas plantas e possui pós-graduação em qualidade. $\mathrm{O}$ analista $\mathrm{A} 3$ trabalha no centro técnico de garantia e é tecnólogo em processos de produção.

Declarações do agente A1

k) Aplicação de metodologia em garantia dá resultados expressivos, o que pode reforçar sua aceitação pessoal e apoio gerencial.

"Em garantia o ganho em 10 anos foi que passamos de 3 falhas/veículo para 0,3 falhas por veículo, dá convertido em 1/5 de gasto de garantia (faixa de centena de milhões)."

1) Aplicação de metodologia ficou muito focada a problemas e a projetos da área da qualidade. 
"Faltou por ciúme da empresa implementar como método oficial em todas atividades, administrativa (muita ineficiente), teria tido mais ganhos, ficou restrito a qualidade e alguns de rh com plano de sugestões."

m) É importante o acompanhamento de projetos por especialistas internos no processo, para validar ações e análises, as vezes muito técnicas.

"Enquanto tinha um suporte técnico de pessoal expert interno, funciona bem, porque o consultor sozinho não consegue perceber se está sendo enrolado, a menos que o consultor seja especialista no processo tecnicamente, sendo superficial, porque as pessoas apresentam números e resultados fajutos, mas o resultado não existe."

n) $\mathrm{O}$ agente deve conseguir treinar o diretor cético quanto a metodologia e ele passou a acreditar que em alguns problemas a metodologia deveria ser aplicada.

“O agente disse ao diretor de qualidade: 'Eu preciso te ensinar algumas ferramentas para você ser o catalisador, o seu peso é muito maior, ele captou e aprendeu fazer leitura."

o) Um diretor com conhecimento técnico consegue apoiar muito através de não aceitar soluções paliativas.

"Como o diretor conhecia muito de ferramental e nossos principais problemas basicamente era casos de fornecedores sem controle de desgaste de ferramentas, ele ajudou muito a cobrar soluções e isto foi atípico, um ponto fora da curva."

p) Um diretor com conhecimento técnico consegue apoiar muito através de não aceitar soluções paliativas.

"Como o diretor conhecia muito de ferramental e nossos principais problemas basicamente era casos de fornecedores sem controle de desgaste de ferramentas, ele ajudou muito a cobrar soluções e isto foi atípico, um ponto fora da curva. Ele dizia: 'Me traz a peça até a tarde na minha sala que eu quero ver a peça, sempre fazia avaliação de fornecedores sobre o seu conhecimento técnico e fazia a turma trabalhar o tipo de questionamento para chegar na causa."

q) Os melhores projetos se originam do pessoal com grande conhecimento técnico prévio. 
"Pode ser treinado, mas se não aprofunda tecnicamente na área não adianta muito. Para melhorar começamos a trazer pessoas da própria engenharia para trabalhar na melhoria. Quando começamos a trazer gente da engenharia que sabiam os detalhes do projetoe foram treinadas na metodologia o efeito foi muito rápido. Quando o cara conhece muito do assunto, pouco conhecimento já é suficiente. $\mathrm{Na}$ verdade é ensinar a pessoal técnica a usar a ferramenta, daí o impacto é grande."

r) Apenas a presença do presidente em uma reunião mensal sobre problemas de qualidade de garantia já foi suficiente para mobilizar estruturas de outros departamentos, como a engenharia.

"Papel fundamental é da postura do presidente da empresa. Porque não adianta, ele é o cara que define as diretrizes. No início do programa entrou um presidente novo que disse: ' escuta tem alguma reunião sobre qualidade, senão eu quero uma reunião mensal'. No início a engenharia nem vinha, mas quando o presidente começou a participar o próprio VP da engenharia começou a vir."

s) A crise não afetou a continuidade de novos projetos de melhoria na área de garantia, apenas mudou o enfoque de melhoria da qualidade para redução de custos de forma robusta.

“Quando se chega no nível de 0,3 falhas por veículo, a conta fica mais difícil. Havia casos nos tempos de vagas gordas, podemos melhorar mas vai ter custo adicional pois a solução não paga. O presidente falava eu pago. Porém esta história que qualidade não tem custo é errada, a qualidade custa sim. Hoje no cenário de vacas magras está no caminho inverso, vamos tirar para ele reclamar um pouco, mas conseguir uma redução de custo. Quando se produz 1/3 do que está produzindo é preciso correr o risco de o cliente reclamar um pouco mas vamos reduzir o custo."

t) A internalização da melhoria contínua ocorre para alguns agentes de forma muito forte.

“A rotina me irrita. Pergunto sempre: Que eu vou fazer de melhor hoje, todo dia. Mesmo sem me pedirem eu desenvolvi ferramentas que nem tem na matriz. Ele me ajuda a fazer melhoria pois gera um relatório que o próprio gerente vê o nível e custo de falhas de cada peça, o que ajuda a selecionar novos projetos para todo o time de garantia" 
u) A maior alavancagem é quando a alta direção internaliza a importância de usar metodologia na busca da melhoria contínua.

“Em montadora funcionário faz o que o chefe pede. A empresa tira o chefe, fica largado. Por isso que nós tivemos a estratégia de convencer o capataz-mor, o diretor da qualidade. Combinamos que eu levanto a bola e você chuta a bola na cabeça do cara. Aí o diretor adorou a ferramenta e fez o gerente trabalhar, que cascateou até os analistas. Não tem sucesso se não tiver o desejo da alta direção. Número e fatos ajudam muita gente com muita boa vontade, mas algumas pessoas só fazem quando o chefe manda."

Declarações do agente A2

h) A abordagem de treinamento com caso real ajuda muito a realização de projeto e entender a metodologia.

"Trabalhei com outra consultoria, mas não conseguia trazer exemplos práticos e tive dificuldade de entender o método. Como vocês são pessoas que vivem a nossa realidade e acaba sendo mais fácil para entender como conduzir o projeto. ”

i) Equilíbrio de apagar logo o incêndio, mas não parar o projeto antes de ações definitivas.

"a planta quer muito mais rápida a resposta e o projeto demanda mais flexibilidade de apagar o incêndio e não jogar a metodologia fora. O problema hoje é ao iniciar um projeto, a gestão quer uma resposta mais rápida. A gestão não aguarda as etapas, não respeita o timing do projeto"

j) Mudou o gestor, a área parou de aplicar metodologia em projetos de melhoria. O perfil de promoção dos gestores deve ser considerado ao realizar promoções

"O supervisor antigo tinha uma visão de continuidade em aplicar isso, depois que ele foi embora nunca mais falaram. Exemplo: gestor atual da minha área é o mais imediatista, ele não pensa em gastar um tempo a mais e resolver assim, então é o próprio perfil do gestor precisa ser escolhido melhor. E isso contamina o time, parece que falo com a porta. O pessoal é muito imediatista. No meu caso por exemplo: Eu não falei que estava fazendo o projeto, fiz uma auditoria e identifiquei o problema, fazia extraoficialmente reuniões de 1 hora por semana, eles me chamavam para ir a área, eu embutia a rotina e não avisava, se eu avisasse eu não sabia o que o gestor ia falar.” 
k) Incentivo errado: fazer cursos ou abrir novos projetos

"Nosso coordenador gostava de ajudar e te ligava depois de 2 a 3 semanas, mesmo quando deixou de ser atividade dele, até hoje ele gosta do que faz. Na verdade era ele, se subir um nível já não era a mesma coisa. Fizemos um projeto e daí acabou, morreu, não havia incentivo a ter outros, isso ficava a cargo do gestor, e o incentivo era mais ligado a fazer mais cursos."

1) $\mathrm{O}$ apoio ao projeto inicial era muito mais forte do que para novos projetos.

"Quando está fazendo o projeto oficial tem ajuda de todos, mas no meu caso é o projeto interno (não acompanhado pela consultoria), precisa chegar no supervisor e precisar ajuda do reparador, no engenheiro de processo, tem que ter influência ou alguém que suporte este auxílio."

m) A liberação de verba para investimento em soluções identificadas nos projetos de melhoria precisa de critérios claros e objetivos.

"O controler tem direcionamento do chefe dele, se o chefe falar não ele replica, ele teria de vender minha ideia para o gestor dele e não sabia como ele vendia. Poxa eu te mostrei um monte de coisa e o outro que pediu um investimento para outra área libera a verba, não sei o critério de decisão."

n) A liberação de verba para investimento em soluções identificadas nos projetos de melhoria precisa de critérios claros e objetivos.

"O controler tem direcionamento do chefe dele, se o chefe falar não ele replica, ele teria de vender minha ideia para o gestor dele e não sabia como ele vendia. Poxa eu te mostrei um monte de coisa e o outro que pediu um investimento para outra área libera a verba, não sei o critério de decisão."

o) É muito importante o agente interno explicar o que está acontecendo para a equipe, não apenas usar o tempo e conhecimento dela.

"O monitor que ajudou no meu projeto até hoje quando o assunto é de projeto de melhoria ela 'fala "eu sei que isto resolve". Embora nunca teve curso, mas participou ativamente do meu projeto, virou um adepto. " 
Declarações do agente A3

h) Pressão de tempo acaba reduzindo a qualidade dos projetos, então deveria ser ensinado como otimizar o tempo de análise e condução de projeto.

"Hoje a rapidez de ter que fazer as coisas. Antes tínhamos tempo de pesquisar. Poderia melhorar a condução de projetos se soubéssemos atuar com maior rapidez na tomada de decisões e no engajamento. Hoje não te permite muito estudo ou planejamento. Como reagir e trabalhar com prazos menores, ser mais assertivo, os executivos mudaram. ”

i) Etapa de padronização mal realizada minava a qualidade dos projetos.

"A dificuldade era um tempo imposto não real de padronizar a rotina e acompanha-la, especialmente para projetos que tinham demandas maiores de tempo."

j) A alta direção deveria apoiar e comprometer-se explicitamente com a realização de novos projetos.

"O apoio a continuidade para os próximos projetos deve ser feito no dia a dia pela alta direção, incluindo disponibilizar recursos para um diagnóstico melhor. ”

k) O coordenador deve avaliar o grau de dificuldade dos projetos e ajudar os agentes a selecionarem projetos apropriados ao nível de recursos existentes para realizá-los..

"O coordenador tem papel muito importante, se for apenas reportar e passar números não funciona, deve ter uma noção do grau de dificuldade do projeto."

1) O gestor deve ajudar o desenvolvimento técnico e comportamental, em especial a atitude de ter segurança ao demonstrar seu projeto em situações não politicamente favoráveis.

"Chefe imediato deve saber os fundamentos da metodologia e entender a postura e dificuldades do agente. Definir as prioridades para o agente. O que faz acontecer é a atitude. Exemplo: analisou e concluiu não seguiu até o fim acontece muito e faltou atitude para ir até as últimas consequências. "Isso sempre foi ação", "este cara vai me barrar" e para no maio do caminho. O perfil do agente deve ser que após descobrir fatos e dados não deve temer os conflitos e dai barra, não pode ter medo de entrar em conflitos. "Ah e se chegar lá o cara vai 
me perguntar, mesmo estando coberto de razão". "Isso vai prejudicar fulano, mas ele tem que se mexer e resolver". O agente de melhoria não pode ter medo. Insegurança prejudica a pessoa. $"$

m) Em funções que demandam análise e solução de problemas, os projetos de melhoria são incorporados na rotina de maneira natural e consistente.

"Metade foi o fator pessoal que influenciou eu continuar iniciando novos projetos, porque eu achei importante e não queria deixar de praticar. A outra parte é exigência, porque na área que eu trabalho, se eu não usasse metodologia para promover a solução de problemas eu cairia em desprestígio, até porque meu trabalho demanda estudo estatístico. Eu conheço pessoas da área de manufatura que não concluíram, não se consegue fazer, porque a rotina é apagar fogo. Dá até para parar, mas por pouco tempo (se tiver vontade tudo dá para fazer), mas como tem problemas crônicos dentro destas áreas eu entendo quem não consegue decolar. Agora com este ritmo de produção baixo de 2015 e 2016 dá para fazer mais. ”

n) Os funcionários em fim de carreira tendem a não iniciar novos projetos. Mas também existem aqueles que adotam a postura de omissão e só fazem se forem pressionados. "Existem os que empurram e empurram e não vai, a pessoa põe um limite em si próprio. Tem dois casos: 1) caso do fim de carreira e não vou mais esquentar a cabeça. 2) postura omisso que independe de idade e escolaridade, é da pessoa" 
APÊNDICE 3 - Informações e Declarações oriundas das entrevistas da Montadora B

Abaixo estão apresentadas as declarações mais relevantes oriundas das entrevistas nas montadoras B, na forma de extratos das principais afirmações coletadas durante as entrevistas. As declarações são descritas entre aspas, em itálico e com espaçamento entre linhas simples. Os temas destas declarações são colocados acima e funcionam como um sumário principal inferido a partir das declarações.

Foram entrevistados: o coordenador de melhoria contínua, um gestor e três agentes internos de melhoria.

\section{1) Entrevista junto ao coordenador de melhoria da Montadora B}

As respostas em relação as assertivas do roteiro de entrevista estão descritas abaixo:

Reposta sobre a expectativa de continuidade dos projetos: "7 - Concordo Fortemente"

"É esperado que, após a conclusão de sua capacitação, cada profissional passe a identificar e realizar projetos de melhoria para atingir objetivos de desempenho e resolver problemas crônicos, transformando-se num efetivo agente interno de melhoria contínua."

Resposta sobre a realidade de continuidade de projetos: "4 - Neutro"

"Os agentes internos capacitados continuaram a implantar projetos de melhoria de forma sistemática, mesmo após o término da capacitação inicial. "

Abaixo estão descritos os principais temas relatados pelo coordenador de melhoria contínua, que atua há mais de 10 anos no escritório de WCM da montadora B e é pós-graduado.

n) A busca de projetos de melhoria contínua é um requisito do grupo e a consistência e profundidade dos projetos é parte de um indicador que compara o nível de maturidade em excelência das operações entre plantas do grupo.

"A excelência é uma imposição do grupo e parte da alta direção de operações. Somos avaliados pela qualidade e robustez dos projetos de melhoria realizados pelos agentes internos." 
o) O líder de produção é a função mais importante de aderir a realização dos projetos de melhoria.

"Decidimos treinar os líderes porque eles são os modelos para todo o pessoal da produção. Nossa direção não economizou em termos de tempo de treinamento e alocação para realizar projetos no programa inicial de capacitação e isto é fundamental, porque depois que eles voltam para rotina fica difícil de realizar melhoria se ele já não tiver uma experiência mais tranquila de ter conduzido pelo menos um projeto e ver que não é um bicho papão."

p) Os melhores líderes foram promovidos ou mudaram de área.

"A grande maioria dos melhores líderes em termos de aprendizagem e do projeto inicial foram promovidos ou foram para funções de suporte a manufatura na área industrial. "

q) O bom projeto é aquele que realiza a integração com demais pilares para garantir a sustentabilidade dos resultados.

"Nós esperamos que os projetos de melhoria de problemas mais crônicos revejam padrões não só de seu pilar, mas dos outros. Exemplo: um projeto de melhoria da qualidade pode ter que padronizar a manutenção autônoma na máquina, que é outro pilar, para garantir sua sustentabilidade."

r) O papel do RH na área é fundamental para ouvir as demandas dos gestores e alinhar expectativas com a consultoria.

"O analista de $R H$ que atua próximo a área consegue passar para a consultoria as nossas particularidades e isso gera um programa de capacitação mais adequado a nossa realidade."

s) Capacitação em imersão gera uma visão sistêmica da excelência em cada agente. "Decidimos dar um banho de loja em termos de conteúdo. Sabíamos que estávamos promovendo muitos dias de treinamentos, mas encaramos como um investimento, pois todos reconhecem que depois que o líder volta para a área fica difícil não virar bombeiro, então decidimos por uma capacitação em imersão total, onde o líder antigo se afastou totalmente das atividades de gestão da área e a outra parte de líderes novatos, recém contratados como trainee ainda não tinha entrado na rotina da área."

t) Alta direção e gestores não pode aceitar no dia a dia apenas soluções paliativas. 
“O maior desafio é que estes líderes não podem aceitar a implantação apenas de soluções provisórias e retrabalhos. Não é porque o problema sumiu que ele não existe. É papel dos gestores dos líderes e da alta direção cobrar projetos que atacam a causa raiz."

u) Em áreas produtivas ligadas a montagem há uma tendência maior de projetos imediatistas serem aceitos. Na área de transformação, como pintura, a tendência é analisar os parâmetros de processo, a máquina, o meio ambiente, tornando mais crítica a análise de sugestões de melhoria.

“A área de montagem é a mais ávida por soluções rápidas e a área de pintura é a mais crítica com soluções de curto prazo. Cada um sabe onde aperta o calo."

v) Coordenador de pilar deve estar presente na fábrica.

“Coordenador precisa conhecer a fábrica e as pessoas, para poder cumprir seu papel de apoiar a realização dos projetos. As vezes tem que pegar na mão e fazer parte do grupo de trabalho e não apenas controlar os indicadores de melhoria."

w) Melhoria pode ser restauração de padrões ou estabelecimento de novos padrões.

"Chamamos de melhoria rápida os acertos e correções de processos instáveis, restaurando padrões de trabalho a condição original. Mas também esperamos projetos mais elaborados que ataquem problemas crônicos e utilizem uma metodologia mais estruturada."

x) Adaptação dos materiais a exemplos da planta ajuda a quebra de resistências a aplicação de metodologia e ferramentas de melhoria.

"Como recebemos manuais e exemplos de implantação de ferramentas da matriz, vemos como muito importante implantar casos pilotos no Brasil e compilar as lições aprendidas no nosso manual local. Estes casos também são usados em treinamento. A consultoria ajudou a montar os materiais usando estes casos locais, que são mais entendidos pelos líderes daqui e quebra resistência, porque é só ir na linha onde a melhoria foi feita e verificar na prática."

y) A implantação de área modelo é a melhor maneira de começar a melhoria num setor. "A melhoria é mais compreendida no setor quando ao invés de projetos isolados, uma parte do setor é eleita como modelo e todos os pilares de excelência são implantados lá, ou seja, ao 
invés de um kaizen de melhoria da produtividade, implantamos padrões de trabalho, segurança, qualidade e manutenção, dando mais robustez ao processo. "

z) A grande dificuldade do agente é transformar seu tema em prioridade para outras áreas.

“Em algumas áreas observa-se que os gestores só correm atrás de melhoria porque a auditoria do modelo de maturidade em excelência, que é feita por auditores externos, está próxima de acontecer."

\section{2) Entrevista junto a um gestor da Montadora $B$}

As respostas em relação as assertivas do roteiro de entrevista estão descritas abaixo:

Reposta sobre a expectativa de continuidade dos projetos: "7 - Concordo Fortemente"

"É esperado que, após a conclusão de sua capacitação, cada profisssional passe a identificar e realizar projetos de melhoria para atingir objetivos de desempenho e resolver problemas crônicos, transformando-se num efetivo agente interno de melhoria contínua."

Resposta sobre a realidade de continuidade de projetos: "4 - Discordo fortemente" "Os agentes internos capacitados continuaram a implantar projetos de melhoria de forma sistemática, mesmo após o término da capacitação inicial. ”

Abaixo estão descritos os principais temas relatados por um dos gestores, que atua como supervisor na área de montagem da Montadora B e possui graduação em engenharia.

f) Contratação da consultoria teve o propósito de trazer um treinamento prático para que os agentes internos pudessem elaborar projetos de melhoria e auxiliassem a implantação dos pilares do modelo de excelência em suas áreas.

"A consultoria foi contratada para desenvolver um treinamento customizado as nossas necessidades. Cada gestor de cada área tecnológica enviou casos práticos que foram usados para elaborar o material de treinamento." 
g) O gestor deve acompanhar o projeto inicial de cada agente interno de melhoria da sua equipe.

"Foi muito importante o gestor acompanhar os líderes na volta do treinamento, pois eles vinham cheios de dúvidas práticas e com vontade de melhorar. Alguns líderes vinham me procurar porque o seu próprio chefe não sábio ou não dava atenção para os projetos de melhoria inicial que ele deveria fazer."

h) O modelo de maturidade com avaliações periódicas e com a alta direção cobrando a melhoria da pontuação, faz com que a melhoria seja desdobrada para os gestores, líderes e até operadores.

"O diretor de planta cobrava muito a nossa melhoria de pontuação nas notas de auditoria externa do modelo de excelência do grupo, que são conduzidas aproximadamente a cada 6 meses. Isto ajuda a estar sempre na pauta de todos nós gestores o tema melhoria e implantação do modelo de excelência do grupo. Cobramos os líderes para desenvolverem projetos rápidos e projetos de média complexidade em conjunto com a sua equipe."

i) A estrutura do modelo de maturidade em passos ou etapas favorece a identificação de lacunas de desempenho ou de padronização, que favorece a realização de projetos de melhoria sistematicamente.

"Ao implantar pilares de excelência em operações, os projetos de melhoria surgem naturalmente, porque para avançar a cada etapa na maturidade são identificados gaps e temos de melhorar para avançar."

j) O gestor que conhece a metodologia apoia muito mais assertivamente. O treinamento do gestor é fundamental para ele não se sentir "ultrapassado" pelo líder de sua equipe que foi treinado como agente interno de melhoria.

"Alguns gestores começaram a perceber que ficaram para trás. Quando os agentes internos voltavam do treinamento com dúvidas e com exemplos de projetos, muitos dos gestores, por não terem a oportunidade de realizar uma capacitação completa, evitavam o tema e deixavam os agentes sozinhos com seus projetos."

1.3) Entrevista junto aos agentes internos de melhoria da Montadora B 
As respostas em relação as assertivas do roteiro de entrevista estão descritas abaixo:

Reposta sobre a própria continuidade dos projetos: "Analista A1: 7 - Concordo Fortemente, Analista A2: 7 - Concordo Fortemente, Analista A3: 7 - Concordo Fortemente, Analista A4: 7 - Concordo Fortemente"

"Eu continuo a implantar projetos de melhoria de forma sistemática, mesmo após o término da minha capacitação inicial."

Resposta sobre a qualidade de apoio recebido para dar continuidade de projetos: "Analista A1: 5 - Concordo levemente, Analista A2: 5 - Concordo levemente, Analista A3: 7 Concordo Fortemente, Analista A4: 5 - Concordo levemente

"O programa atualmente ainda depende dos agentes internos (como eu) para desencadear os projetos. Se eu não puxar as melhorias não acontecem. "

Resposta sobre a percepção do papel do agente interno como agente de transformação do programa de melhoria contínua: "Analista A1: 7 - Concordo Fortemente, Analista A2: 7 Concordo Fortemente, Analista A3: 4 - Neutro, Analista A4: 7 - Concordo Fortemente

$\mathrm{O}$ agente interno consegue transformar ou mudar o comportamento de outras pessoas e fazêlas ter iniciativa para melhoria contínua.

Abaixo estão descritos os principais temas relatados por quatro agentes, que atuam como líderes de produção da Montadora B. O agente A1 tem formação de técnico mecânico, A2 é engenheiro de produção, A3 é pós-graduado em logística e A4 é tecnólogo em processos industriais.

Declarações do agente A1

d) A abordagem prática do treinamento com apresentações acabou auxiliando o agente interno no trabalho em equipe.

"As dinâmicas utilizadas durante o treinamento, uso da metodologia, exposição no flip chart e os coachings me ensinaram a trabalhar em grupo."

e) O treinamento precisa conter desafios atitudinais ligados aos valores esperados pela empresa. 
"Faltou exemplos da realidade em como pôr em prática os valores da empresa, por exemplo segurança. Os líderes precisam construir no dia a dia o trabalho padrão da segurança Precisava de casos improvisados na sala por exemplo uma vassoura caída no meio do caminho e desafiar o time perguntando: Qual a atitude do líder?."

f) A comunicação dos objetivos do processo de capacitação deve ser feita claramente pela alta direção, sob o risco de gerar percepções negativas da importância de realizar projetos de melhoria.

“Tivemos uma condução autoritária pela obrigação de fazer o projeto e não pelo esclarecimento, não houve desenvolvimento, houve cobrança."

Declarações do agente A2

e) Aplicação de metodologia em projeto real é fundamental para o agente interno adquirir segurança na aplicação de metodologia nos projetos de melhoria.

"O que mais significou para minha formação foram as atividades On the Job, aplicação do conceito no local de trabalho principalmente a semana Kaizen. Isto ajudou muito para o exercício de minhas atividades atuais. "

f) Ao cobrar pelos projetos a direção deve mostrar-se disponível por participar dos mesmos, ou seja, liderar o caminho.

"Alta direção não participou efetivamente. Eles trabalhavam questionando por meio de pressão. Deveriam ter participado mais."

g) Os coordenadores devem estar presentes para que os novos projetos tenham um suporte após o término da capacitação inicial, já que a figura do consultor externo desaparece neste momento.

"Os coordenadores de pilar foram muito presentes no momento da capacitação, mas hoje no dia-a-dia da fábrica são muito ausentes."

h) O líder de produção deve empoderar-se como dono do processo de melhoria de sua área. 
"Não é somente o líder que faz melhoria contínua, pois há uma estrutura de suporte formada por analistas, gestores, engenheiros e coordenadores de melhoria. Porém nós fomos treinados para fazer melhoria e nós somos o dono deste processo"

Declarações do agente A3

c) Aprender a trabalhar com metodologia foi muito valorizado pelos agentes da Montadora B.

"Tudo que vivenciamos naquele treinamento é traduzido como experiência de vida. A metodologia me ajudou a concluir a minha monografia do MBA e a desenvolver minha capacidade de Gestão Logística."

d) É necessário desenvolver nos gestores uma visão de foco nos processos e não apenas foco nos resultados.

"O foco da minha chefia imediata sempre foi entregar uma quantidade de carros por hora e existia uma obstrução sistêmica para que as melhorias fossem implantadas. "

Declarações do agente A4

b) Aprender a trabalhar com metodologia foi muito valorizado pelos agentes da Montadora B.

"Todos aqueles fundamentos apreendidos é parte do meu dia a dia. Esta é a importância, aquela foi a base."

c) Aprender a trabalhar com metodologia foi muito valorizado pelos agentes da Montadora B.

"Os coordenadores de pilar são muito passivos, não acompanhando a produção, e tem uma estrutura totalmente política dentro da fábrica." 
APÊNDICE 4 - Informações e Declarações oriundas das entrevistas da Montadora C

Abaixo estão apresentadas as declarações mais relevantes oriundas das entrevistas nas montadoras $\mathrm{C}$, na forma de extratos das principais afirmações coletadas durante as entrevistas. As declarações são descritas entre aspas, em itálico e com espaçamento entre linhas simples. Os temas destas declarações são colocados acima e funcionam como um sumário principal inferido a partir das declarações.

Foram entrevistados: o coordenador de melhoria contínua, um gestor e três agentes internos de melhoria.

\section{1) Entrevista junto ao coordenador de melhoria da Montadora $C$}

As respostas em relação as assertivas do roteiro de entrevista estão descritas abaixo:

Reposta sobre a expectativa de continuidade dos projetos: "7 - Concordo Fortemente"

"É esperado que, após a conclusão de sua capacitação, cada profissional passe a identificar e realizar projetos de melhoria para atingir objetivos de desempenho e resolver problemas crônicos, transformando-se num efetivo agente interno de melhoria contínua."

Resposta sobre a realidade de continuidade de projetos: "4 - Neutro"

"Os agentes internos capacitados continuaram a implantar projetos de melhoria de forma sistemática, mesmo após o término da capacitação inicial. "

Abaixo estão descritos os principais temas relatados pelo coordenador de melhoria contínua, que atua há mais de 15 anos na montadora, com 2 anos coordenando o escritório de melhoria contínua, e é graduado em administração.

1) O apoio do diretor de planta foi decisivo para a quantidade e qualidade dos projetos. "O diretor de planta participava da escolha de cada agente interno de melhoria e aprovava o projeto junto do gestor do agente logo no início do programa. Todos faziam projetos lembrando que no final tinham que apresentar para o diretor, portanto houve um alinhamento muito positivo com a necessidade de completar com sucesso o projeto inicial ligado a capacitação. " 
m) O uso de métricas não só financeiras para avaliar o resultado dos projetos foi muito importante para concluir alguns projetos.

"O diretor de planta não cobrava necessariamente um resultado financeiro. O que importava é se o projeto ia dar resultado para o time."

n) $\mathrm{O}$ resultado financeiro inicial apareceu, mas com a mudança de diretoria perde-se a estrutura de monitoramento dos projetos.

"Dos projetos fechados conseguiu-se 1,4milhão. O resultado continua ainda hoje é o aprendizado. Claro que uma grande maioria caiu no esquecimento."

o) Foi implantado um processo formal de reporte de resultados e avançamento de projetos, fundamental para manter os projetos dentro do prazo e objetivos.

"Manufatura era dona do programa e o patrocinador do programa, não a qualidade como na Montadora A. Para os gerentes o coordenador reportava direto qualquer problema com o projeto ou com o agente. $\mathrm{O}$ reporte para os gerentes era através de uma reunião após cada fase de consultoria, ou seja, a cada 3 semanas, onde se repassava agente por agente. Durante a reunião o gestor já fazia contato querendo saber o que ocorreu e o que deveria ser feito para melhorar e voltar a uma nota verde. Para o diretor de planta era um resumo a cada mês. Durante as consultorias o gestor de cada agente era convidado a participar e um indicador de presença do gestor era reportado ao diretor de planta."

p) A alta direção estabeleceu um diálogo com todos os níveis de operações para identificar projetos relevantes.

"Foco do diretor de planta foi fundamental para os resultados. Ele queria saber sobre a qualidade dos treinamentos (conteúdo) e o tipo de respaldo dado aos agentes internos que não estavam conseguindo atingir o desempenho adequado do projeto. Estabeleceu a meta de 1 projeto/ano / agente. Valorizava muito a voz do chão de fábrica para apontar oportunidades de projeto. Ele fez uma carta de time por time para levantar oportunidades de projetos (tipo de pesquisa onde o próprio diretor de planta perguntava a cada monitor de cada time). Cada time recebeu uma cópia da carta com assinatura dele e do gerente da área. Cada monitor deveria conversar com seu time e apontar os dois pontos que mais incomodava o time. Respostas "a essa peça não monta, isso entra agua, quando monto a peça quebra". Este era o pedido dele, o 
pessoal apontou e eu sentei com líderes de cada área para validar os temas classificando: Kaizen rápido, Tema complexo e temas menos complexos."

q) A alta direção estabeleceu um canal de comunicação direto com o coordenador de melhoria contínua.

"Eu nunca saí da sala dele falando "ele me deixou na mão", a porta da minha sala está sempre aberta para vocês. Dificilmente não seguia a minha recomendação. ”

r) $\mathrm{O}$ agente interno deve apresentar as informações com robustez e com segurança, para evitar a falta de confiança do gestor na qualidade das informações.

“Alguns gerentes, por não conhecerem a ferramenta, eram muito resistentes, pois não visualizava a importância do trabalho para o grupo dele. Exemplo: Na estamparia o gestor era muito resistente. Uma chapa com ondulação e deveria ter feito uma modificação na ferramenta, não acreditava nos dados que tinha que parar a ferramenta e não dava importância, não confiava na informação. ”

s) Embora se reconheça o papel da alta direção, quando um gestor internaliza a importância de usar metodologia de melhoria, ele estabelece esta prática na rotina de sua equipe.

"Umas 20 pessoas ainda continuam usando as ferramentas. Em 2014 até mês 4 ou 5 começou as férias coletivas e começou novos modelos de carros. A meta de 1 projeto por ano só foi atingida pelo pessoal de soldagem 2015 (30 a 40 pessoas na armação), pois a queda nas vendas e redução da estrutura de melhoria seguida da saída do diretor da planta, retirou toda a pressão por realizar projetos melhoria."

t) Em empresas com sistemática de avaliação de desempenho, os projetos de melhoria deveriam fazer parte das dimensões avaliadas.

“O envolvimento do RH não ocorreu. $\mathrm{O}$ ideal é que projetos façam parte da avalição de desempenho. O RH ficou muito fora. $\mathrm{O}$ gestor do $\mathrm{RH}$ não conhecia a metodologia e não acreditava. $\mathrm{O}$ diretor de planta foi solicitado, mas não levou este envolvimento para frente. $\mathrm{O}$ resultado deve estar pontuado na ficha de desempenho. Quem tem que puxar o programa é a manufatura com o $\mathrm{RH}$, porque o resultado é outro." 
u) É importante avaliar este perfil no momento da seleção e prover o desenvolvimento comportamental dos agentes que forem participar do programa.

"Existem pessoas que participaram porque era obrigação e não simpatiza com a metodologia, sempre reclamando. São pessoas que não conseguem trabalhar com metodologia, principalmente para os líderes de idade mais avançada (suava para montar o powerpoint e planilha estatística). Outras pessoas entendem e mandam bem, mas são preguiçosas, trabalham só sob pressão e sempre acham desculpas. "

v) É necessário que haja o alinhamento de metas do projeto com prioridades e objetivos da área do agente interno e de áreas de interface.

“O apoio do gestor imediato e gerencia de outras áreas alinhada com objetivo da fábrica. Exemplos: na reunião de logística e todos devem estar alinhados com o resultado que poderá trazer para fábrica, e a gerência deve estar alinhada com a meta do projeto."

1.2) Entrevista junto a um gestor da Montadora $C$

As respostas em relação as assertivas do roteiro de entrevista estão descritas na seção 1.2 do Apêndice 2, porque o gestor escolhido para entrevista atuou como gestor nas duas plantas, montadoras A e C. Quando ocorreu alguma diferença entre as plantas está ressaltado nas declarações do gestor e no sumário relativo a declaração.

1.3) Entrevista junto ao agente interno de melhoria da Montadora $\mathrm{C}$

As respostas em relação as assertivas do roteiro de entrevista estão descritas abaixo:

Reposta sobre a própria continuidade dos projetos: " 6 - Concordo,

"Eu continuo a implantar projetos de melhoria de forma sistemática, mesmo após o término da minha capacitação inicial."

Resposta sobre a qualidade de apoio recebido para dar continuidade de projetos: "7 Concordo fortemente"

"O programa atualmente ainda depende dos agentes internos (como eu) para desencadear os projetos. Se eu não puxar as melhorias não acontecem." 
Resposta sobre a percepção do papel do agente interno como agente de transformação do programa de melhoria contínua: "6 - Concordo"

$\mathrm{O}$ agente interno consegue transformar ou mudar o comportamento de outras pessoas e fazêlas ter iniciativa para melhoria contínua.

Abaixo estão descritos os principais temas relatados pelo agente, que atua como supervisor de pintura da Montadora $C$ há 17 anos e tem graduação em administração de empresas.

Declarações do agente A1

k) A capacitação ajudou alguns agentes a acreditar que a aplicação da metodologia nos projetos de melhoria é importante, mesmo sob pressão de tempo.

"Hoje o chefe diz "quero que seja para hoje", e eu respondo: 'preciso de 1 semana para analisar e saber qual é a causa raiz'. O chefe novo não gosta de ouvir isso, quer ver o troço na hora, mas depois ele valoriza por apresentar uma coisa mais fundamentada. E aquilo que a gente chegava e dava um tiro a cada minuto, agora não faço mais isso, sou mais assertivo ao invés de atirar para todos os lados."

1) Um processo objetivo de seleção de projetos deveria ser adotado, senão o agente fica a mercê de realizar projetos que consideram o interesse da chefia mas sem representatividade para o negócio.

"O chefe deve dar $3 \mathrm{~h} /$ dia ou 20h/semana para focar em problemas, analisa-los e reduzir as falhas. Isso o chefe não faz, não dá condições para isso. Pede outra coisa que não está linkado no top 3 da área e a prioridade vira o que o chefe quer."

m) É muito importante estabelecer um processo de compilação, acesso e utilização de projetos prévios, para ganhar tempo com análise e soluções de problemas similires.

"Dentro de uma página interna colocar todos os projetos feitos ficarem visíveis para que pudéssemos fazer consulta. Ex.: Hoje trabalho em pintura e outra pessoa no meu lugar não tem acesso a estes projetos. ” 
n) Sem um sistema de padronização com sinalização clara das características especiais e um processo de validação das alterações de processo, os projetos de melhoria podem perder sua eficácia inicial.

“O mesmo problema que ataquei no meu projeto de capacitação inicial voltou a ocorrer há 3 meses atrás. Peguei o projeto e vi que a trajetória não estava mais a mesma, o volume de cola não estava mais a mesma. Descobri que o programa do robô para aplicação da cola foi alterado pelo engenheiro de manutenção do robô. Ele não sabia que este padrão de trajetória e volume de resina era crítico. Daí o problema reduziu drasticamente. "

o) A alta direção deve conhecer e exigir a aplicação de metodologia para realização de projetos de melhoria.

"Hoje a alta direção deveria ter o conhecimento e exigir o uso pelo pessoal da área de análise, engenharia e manutenção. A nova diretoria de hoje não conhece e trabalha dando tiro. Falta o conhecimento. Para conduzir precisa conhecer."

p) Se a coordenação de melhoria tivesse acesso a informações sobre novas tecnologias, os projetos poderiam ser mais valorizados e as soluções poderiam também incluir inovações de processo.

"Os coordenadores de melhoria deveriam trabalhar em conjunto com uma área estratégica de tecnologia, pois há hoje muita tecnologia e nós estamos no dia a dia da fábrica e não temos esta visão estratégica de tecnologia."

q) A seleção de profissionais deveria ser condicionada a uma atitude favorável a melhoria contínua, ou no mínimo desenvolvê-la como parte do processo de capacitação.

“Tem cara que aprendeu e não tem o perfil. Se tem uma visão de enxergar oportunidades o cara com o treinamento evolui. Se ele não tem esta mentalidade e percepção de melhoria pode dar 10 treinamentos e não quer fazer. Eu ouvi "isso não serve para nada."

r) O processo de capacitação deveria ser realista no sentido de mensurar que grau de lacuna atitudinal em relação a melhoria contínua é possível transformar com o processo de capacitação e que agentes possuem um grau de atitude tão desfavorável que nem deveriam ser selecionados como agentes internos de melhoria. 
"Existem caras mais velhos e desmotivados, estão na lei 1530 (importante é dia de pagamento, dia 15 e dia 30). O outro tipo é o que não consegue enxergar, a perda está na frente dele o dia todo e ele não vê. Acho ambos os casos muito difíceis de transformar."

s) Um líder que opera num quadro enxuto de indiretos deveria ter apoio de uma área de tecnologia para implantar projetos de melhoria e inovação.

"Nos últimos anos ocorreu uma brusca redução do efetivo (para ter ideia hoje estamos num nível de produção que é 8 vezes menor que nossa capacidade). Hoje 1 pessoa não tem tempo para fazer por conta de fazer outras atividades que não eram do escopo dele. Por isso que precisamos de uma área estratégica para pensar. Hoje eu falo para o meu chefe, eu quero um cara pensando no corpo técnico."

t) O processo de capacitação desenvolveu a capacidade analítica dos agentes internos, que mesmo sem praticar no dia a dia, afeta sua análise de dados e tomada de decisão.

"Hoje percebo que do montante treinado menos de 30\% utiliza a metodologia par resolver problemas ou iniciar projetos (o pessoal das áreas vejo 1 ou 2 de cada área). Mas é nítido durante as reuniões de auditoria quem participou do processo de capacitação e vai apresentar o problema tem uma apresentação muito mais confiável." 
APÊNDICE 5 - Documentos analisados na Montadora A

1. Planilha de Controle de Projetos na Montadora A

\begin{tabular}{|c|c|c|c|c|c|c|c|c|c|c|c|c|c|c|}
\hline \multirow[b]{2}{*}{ comsente } & \multicolumn{14}{|c|}{ AVALIAÇĀO DOS CANDIDATOS } \\
\hline & GEx & cestre: & mejete inciol & imper & merkice & mencis: & mere & 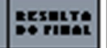 & \begin{tabular}{|c|c|c|} 
GER \\
ol.
\end{tabular} & $\mathbf{D}$ & in & $\mathbf{A}$ & I & C \\
\hline & SUALIDAOE & & & & & & & & $\mathbf{* s}$ & $-17.6 x$ & $10.0 x$ & $\mid=10.8 x$ & $76.7 x$ & $37.4 x$ \\
\hline & SUĂLionot & & & & & & & & $\leqslant s$ & $-10.9 x$ & $10.6 x$ & 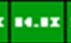 & $31.4 x$ & $23.4 x$ \\
\hline & Locistica & & & & & & & & $* * *$ & $+1 . .4$ & $51.3 x$ & $1.0 x$ & $0.0 x$ & $0.0 x$ \\
\hline & SUALOAOET & & & & & & & & 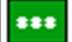 & $28.2 x$ & $18.2 x$ & $=11.2 x$ & $18.7 x$ & a.s. \\
\hline & SUALLOADE & & & & & & & & $\leqslant x$ & $|0.6 x|$ & $\mid 0 . .3 x$ & $=\mid 13.4 x$ & $11.4 x$ & $=04.4 x$ \\
\hline & suatioabe & & & & & & & & $* *$ & $+10.4 x$ & $7 x .2 x$ & $21.4 x$ & $51.2 x$ & $0.1 \mathrm{x}$ \\
\hline & suatioabe & & & & & & & & $2=8$ & $51 . .4$ & $1.0 x$ & $-1.4 x$ & $0 .+x$ & $1.0 x$ \\
\hline & sualloade & & & & & & & & $\operatorname{ses}$ & 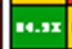 & $50.3 x$ & $1.4 x$ & $0.0 x$ & $0.0 x$ \\
\hline & Logistica & & & & & & & & 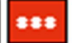 & s.tex & $21.5 x$ & $8.0 x$ & $8.0 x$ & $1.0 x$ \\
\hline & Locistica & & & & & & & & $\approx * s$ & $-1 . .1 x$ & 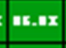 & $=12.2 x$ & $20.0 x$ & $1.0 x$ \\
\hline & SUALIDade & & & & & & & & 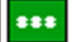 & \begin{tabular}{|l|}
$0.1 x$ \\
\end{tabular} & $12.0 x$ & $=11.2 x$ & $10.0 x$ & $10.4 x$ \\
\hline & Suationot & & & & & & & & $=8$ & \begin{tabular}{|l|}
$10.6 x$ \\
\end{tabular} & $30.2 x$ & $=1 x .5 x$ & $0.5 x$ & $35.5 x$ \\
\hline & OUALIOAder & & & & & & & & $\leqslant x$ & - $10.6 x$ & $10.2 x$ & $31.7 x$ & $31.2 x$ & $12.3 x$ \\
\hline & SUALIDAOE & & & & & & & & 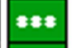 & - $10.6 x$ & $18.5 x$ & $=12.4 x$ & $18.0 x$ & $18.3 x$ \\
\hline & SUALIOAOE & & & & & & & & 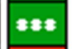 & 10.6x & $18 . .7 x$ & $38.0 x$ & $10.7 x$ & $10 . .3 x$ \\
\hline & SUALIDADE & & & & & & & & 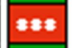 & \begin{tabular}{|l|}
$0.6 x$ \\
\end{tabular} & $78.2 x$ & $53.4 x$ & $1.0 x$ & $1 . x x$ \\
\hline & SUALIDade & & & & & & & & 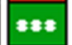 & \begin{tabular}{|l|}
$18.4 x$ \\
\end{tabular} & $31.3 x$ & $n . .3 x$ & $20.7 x$ & $27.4 x$ \\
\hline & ouatlonor & & & & & & & & $2=8$ & \begin{tabular}{|l|}
$0.6 x$ \\
\end{tabular} & $10.5 x$ & $=10.2 x$ & $0.3 x$ & $13.2 x$ \\
\hline & SUALIOAOE & & & & & & & & 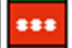 & - $10.1 x$ & $55.4 x$ & $0.1 x$ & D. & $1 . x x$ \\
\hline & SUALOBAor & & & & & & & & 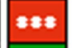 & \begin{tabular}{|l|}
$15.0 x$ \\
\end{tabular} & $23.3 x$ & $52.4 x$ & $0.0 x$ & $0.1 x$ \\
\hline & sualoade & & & & & & & & 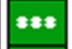 & $20.9 x$ & $31.4 x$ & $33.4 x$ & $13.4 x$ & $1+.4 x$ \\
\hline & SUALIDABE & & & & & & & & 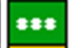 & 10.1x & $10.9 x$ & $x$ & $10.4 x$ & 21.4 \\
\hline & SUationor & & & & & & & & 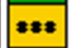 & \begin{tabular}{|l|}
$0.6 x$ \\
\end{tabular} & $12.4 x$ & $=13.4 x$ & $25.2 x$ & 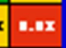 \\
\hline & SUALIOABE & & & & & & & & 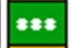 & \begin{tabular}{|l|l|}
$0.6 x$ \\
\end{tabular} & $32.0 x$ & $=11 . .2 x$ & $11.5 x$ & $18.7 x$ \\
\hline & SUALOABDE & & & & & & & & 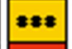 & $17.6 x$ & $13.4 x$ & $21 . .1 x$ & $78.7 x$ & $37.0 x$ \\
\hline & SUALIOAOE & & & & & & & & $\operatorname{ses}$ & 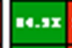 & $32.0 x$ & $0.1 x$ & $0.0 x$ & $0.0 x$ \\
\hline & SUALionor & & & 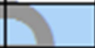 & & & & & $\leqslant * *$ & $\mid 0.4 x$ & $0.0 x$ & -.ux & $0.0 x$ & D.r. \\
\hline & SUALIOAOE & & & & & & & & 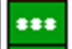 & $18.0 x$ & $13.2 x$ & $x$ & $12.4 x$ & $32.3 x$ \\
\hline & SUALIDade & & & 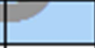 & & & & & 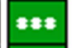 & $12.2 x$ & $31.0 x$ & $x$ & $12.0 x$ & $22.7 x$ \\
\hline & SUALIOAOE & & & & & & & & $* * 2$ & \begin{tabular}{|l|}
$18.3 x$ \\
\end{tabular} & $10.4 x$ & $=11.4 x$ & $10.4 x$ & $23.3 x$ \\
\hline & Suatloaber & & & & & & & & $\leqslant s$ & $31.6 x$ & a $37.4 x$ & $=31.9 x$ & $37.4 x$ & \begin{tabular}{|l|l|}
$x$ \\
$x$
\end{tabular} \\
\hline & SUALIOAOE & & & & & & & & $* * *$ & $10.6 x$ & $17.5 x$ & $22.3 x$ & $58.3 x$ & \begin{tabular}{|l|l|}
$x$ & $0 . .4 x$ \\
\end{tabular} \\
\hline & SUaLionor & & & & & & & & \begin{tabular}{|l|}
$* s s$ \\
\end{tabular} & \begin{tabular}{|c|}
$0.6 x$ \\
\end{tabular} & $10.2 x$ & $12.4 x$ & $11.4 x$ & \begin{tabular}{|l|l|}
$x$ & $11.4 x$ \\
\end{tabular} \\
\hline & SUALIDade & & & & & & & & $2=8$ & \begin{tabular}{|l|}
$10.4 x$ \\
\end{tabular} & $5 x .4 x$ & $x$ & $0.0 x$ & 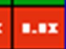 \\
\hline & SUALIDade & & & & & & & & 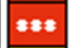 & \begin{tabular}{|l|}
$-18.0 x$ \\
\end{tabular} & $23.3 x$ & $51.6 x$ & $0.1 x$ & $-0.4 x$ \\
\hline & SUALLOADE & & & & & & & & 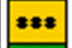 & $20.6 x$ & $12.5 x$ & $\mid 10.4 x$ & $13.2 x$ & \begin{tabular}{|l|l|}
$x$ & $0.0 x$ \\
\end{tabular} \\
\hline & suatloube & & & & & & & & $x=8$ & 10..6x & $11 . .4 x$ & $11.4 x$ & 15.11 & \begin{tabular}{|l|l|}
$x$ & $15.4 x$ \\
\end{tabular} \\
\hline & SUALIOAOE & & & & & & & & $* 2$ & $87.3 x$ & $3 x .5 x$ & $=97.3 x$ & $12.7 x$ & $x=3.3 x$ \\
\hline & SUALBDade & & & & & & & & 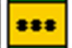 & \begin{tabular}{|l|} 
In. \\
\end{tabular} & $12.7 x$ & $x+13.4 x$ & $77.3 x$ & \begin{tabular}{|l|l|}
$x$ & \\
$x$ & \\
\end{tabular} \\
\hline & SUALLABde & & & & & & & & 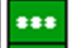 & $10.6 x$ & $10.3 x$ & $=10.4 x$ & $10.4 x$ & \begin{tabular}{|l|l|}
$x .4 x$ \\
\end{tabular} \\
\hline & SUAlloaber & & & & & & & & $\approx * \varepsilon$ & $33.0 x$ & $12.7 x$ & 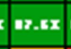 & $10.5 x$ & \begin{tabular}{|l|l|}
$x$ & $13.7 x$ \\
\end{tabular} \\
\hline & suatloabe & & & & & & & & $2=8$ & \begin{tabular}{|l|}
$0.13 x$ \\
\end{tabular} & $10.4 x$ & $5 x .4 x$ & $0.0 x$ & $1 . .1 x$ \\
\hline
\end{tabular}


2. Planilha de Acompanhamento de Projeto na Montadora A

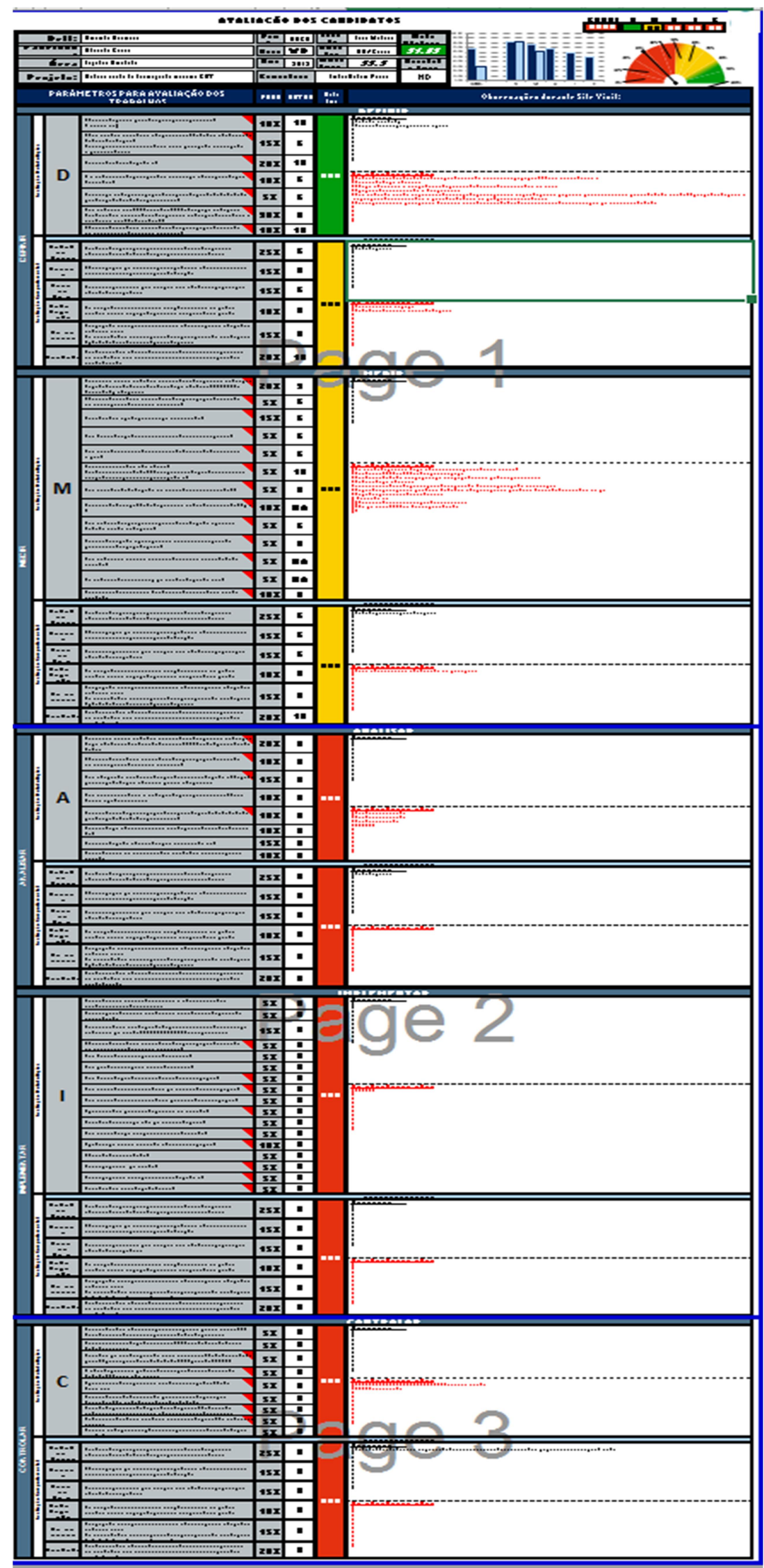


APÊNDICE 6 - Documentos analisados na Montadora B

1. Planilha de avaliação de projetos na Montadora B

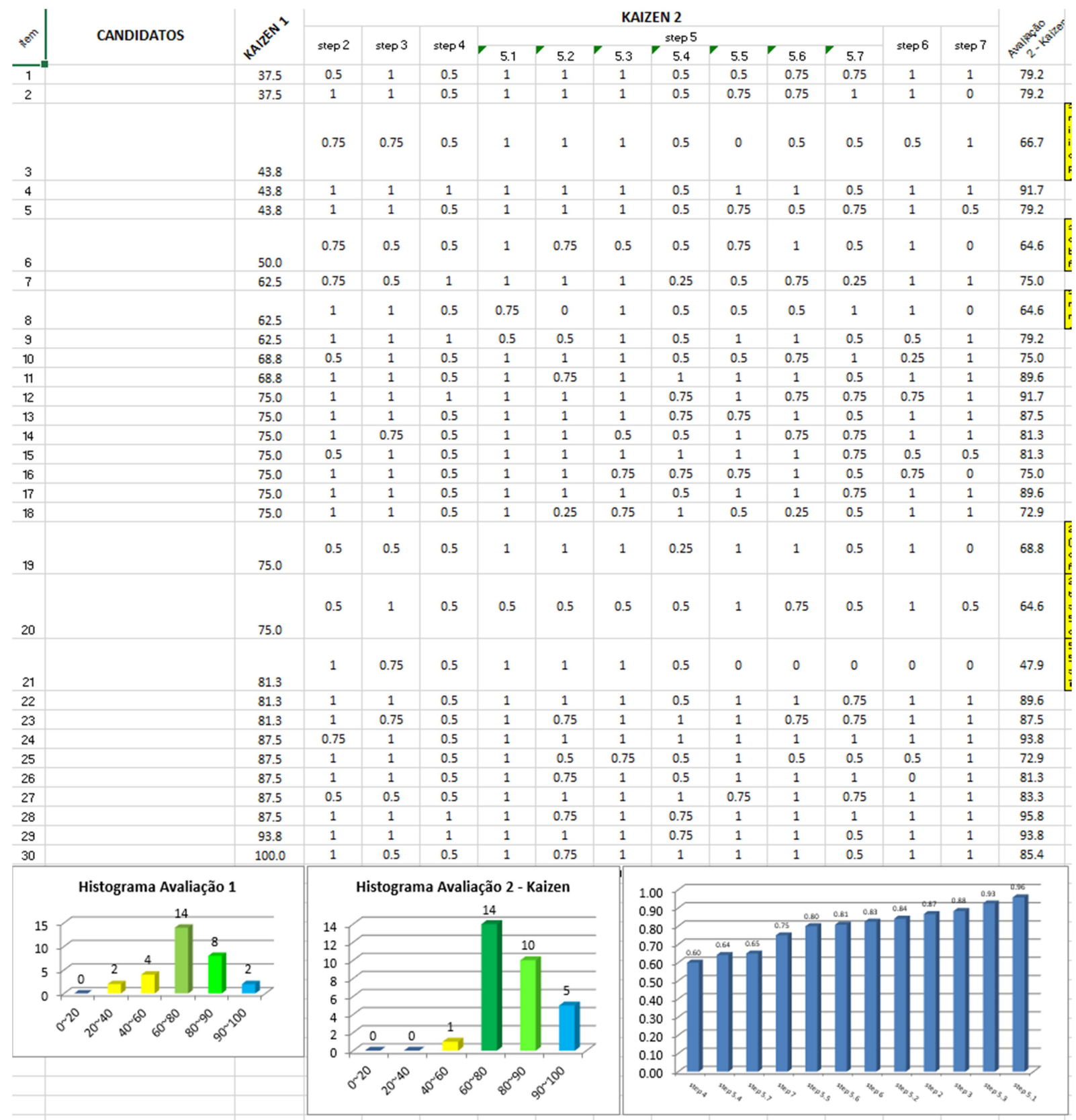


APÊNDICE 7 - Documentos analisados na Montadora C

1. Planilha de Controle de Projetos na Montadora C

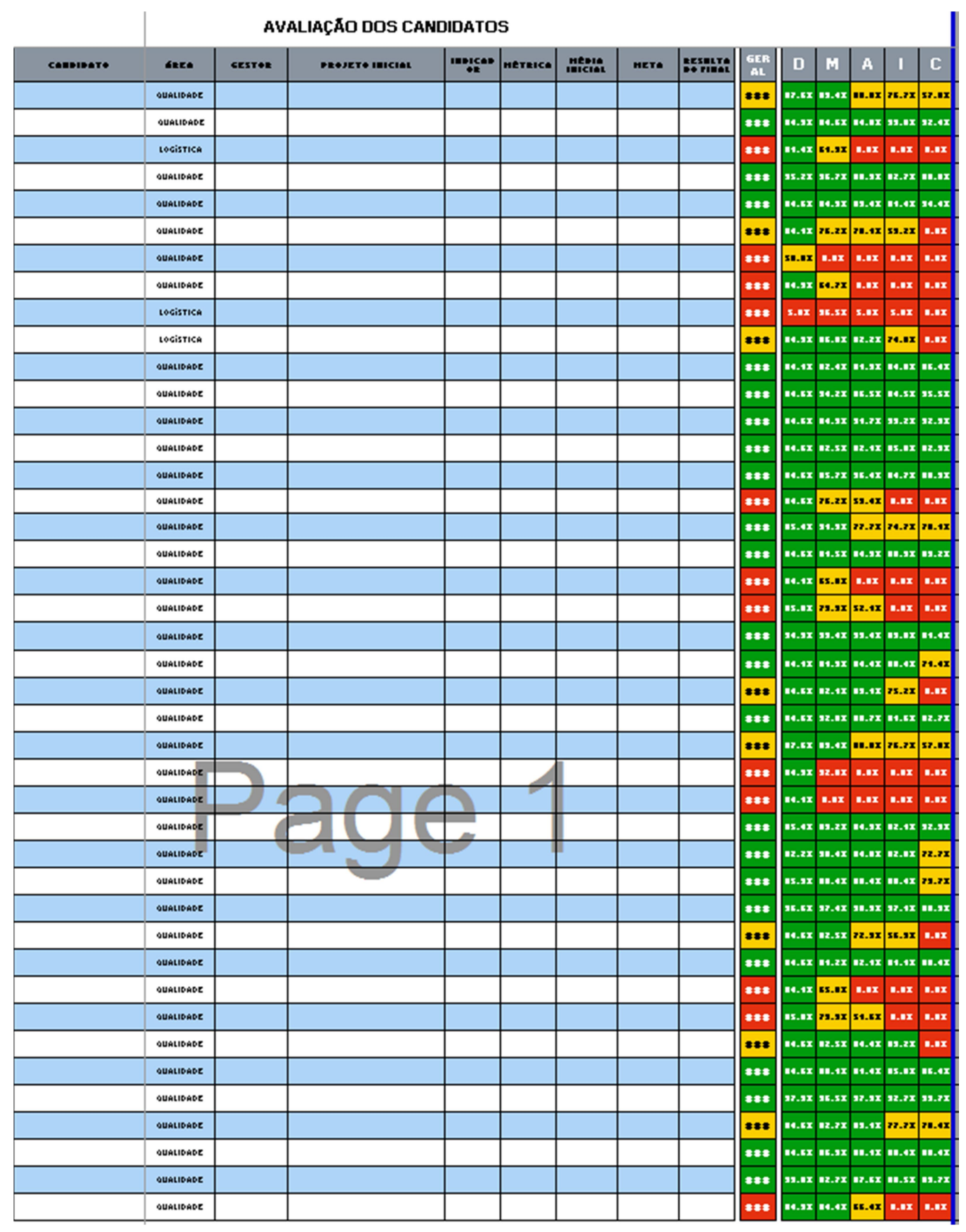


2. Planilha de Acompanhamento de Projeto na Montadora $\mathrm{C}$

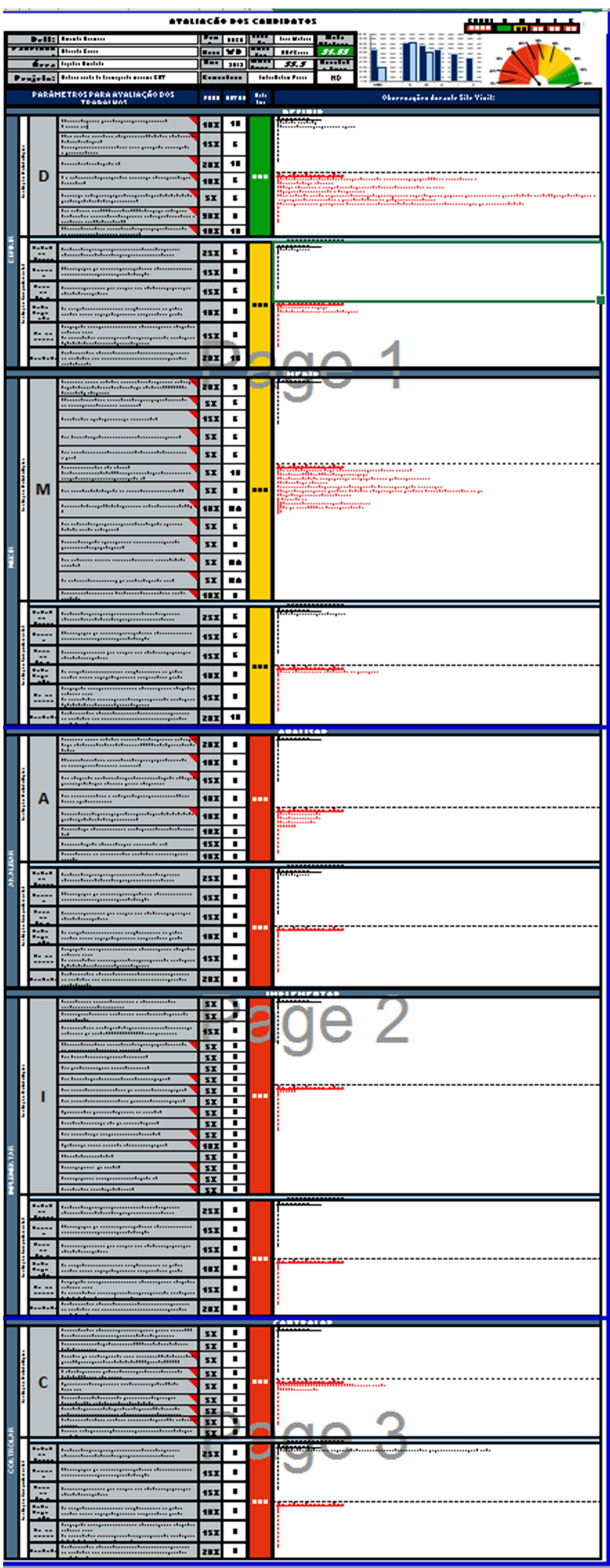




\begin{abstract}
ANEXOS
ANEXO 1 - Roteiro de entrevista do agente interno de melhoria ANEXO 2 - Roteiro de entrevista do gestor ANEXO 3 - Roteiro de entrevista do coordenador de melhoria continua ANEXO 4 - Roteiro de entrevista do consultor externo
\end{abstract}


ANEXO 1 - Roteiro de entrevista do agente interno de melhoria

Bom dia / Boa tarde. Obrigado antecipadamente pela sua disponibilidade. Como nos falamos anteriormente o objetivo desta entrevista é a compreensão do processo de capacitação dos agentes internos de melhoria. A duração prevista será de 45 minutos a 2 horas, de acordo com a sua disponibilidade. Nenhuma informação revelada será documentada com nomes, títulos ou códigos conhecidos de pessoas ou empresas. Podemos gravar a nossa conversa?

1) Caracterização do entrevistado.

Para começar, gostaria que você me descrevesse sua idade, escolaridade e alguma experiência prévia com o tema melhoria contínua, se existir.

2) Processo de capacitação

a. Quais foram os aspectos ou tópicos que você destaca na capacitação e como isso te ajudou? Justifique e exemplifique.

b. O que faltou na capacitação? Justifique e exemplifique.

c. O que deveria ter sido conduzido ou feito de forma diferente? Justifique e exemplifique.

3) Estrutura do programa de melhoria e Papeis.

Descreva o papel teórico (esperado ou definido como ideal) e percepções sobre o seu cumprimento na prática:

a. Alta direção: Atitude e Conhecimento do Método esperados

b. Coordenador de Melhoria Continua: Atitude e Conhecimento do Método

c. Gestores dos agentes internos de melhoria contínua (seu papel): Atitude e Conhecimento

d. Agentes internos de melhoria contínua: Atitude e Conhecimento do Método

e. Outros papeis: Atitude e Conhecimento do Método

4) Resultados.

Descreva os resultados alcançados no projeto de melhoria inicial (projeto realizado durante o seu processo de capacitação) 
5) Continuidade com novos projetos.

Classifique numa escala de 1 a 7, onde 1 é discordo fortemente e 7 é concordo fortemente, a afirmação a seguir: "Eu continuo a implantar projetos de melhoria de forma sistemática, mesmo após o término da minha capacitação inicial. " (ler a tabela abaixo)

\begin{tabular}{|l|l|l|l|l|l|l|}
\hline $\begin{array}{l}\text { Discordo } \\
\text { Fortemente }\end{array}$ & Discordo & $\begin{array}{l}\text { Discordo } \\
\text { levemente }\end{array}$ & Neutro & $\begin{array}{l}\text { Concordo } \\
\text { levemente }\end{array}$ & Concordo & $\begin{array}{l}\text { Concordo } \\
\text { Fortemente }\end{array}$ \\
\hline 1 & 2 & 3 & 4 & 5 & 6 & 7 \\
\hline
\end{tabular}

5.1) Se a resposta anterior for SIM, pergunte: Que fatores pessoais e/ou organizacionais fizeram você a continuar com a implantação de novos projetos de melhoria? Se a resposta anterior for NÃO, pergunte: Que fatores pessoais e/ou organizacionais fizeram você a não iniciar e implantar novos projetos de melhoria?

6) Apoio para a continuidade com novos projetos.

Classifique numa escala de 1 a 7, onde 1 é discordo fortemente e 7 é concordo fortemente, a afirmação a seguir: "O programa atualmente ainda depende dos agentes internos (como eu) para desencadear os projetos. Se eu não puxar as melhorias não acontecem. " (ler a tabela abaixo). Após resposta solicite: Justifique e exemplifique.

\begin{tabular}{|l|l|l|l|l|l|l|}
\hline $\begin{array}{l}\text { Discordo } \\
\text { Fortemente }\end{array}$ & Discordo & $\begin{array}{l}\text { Discordo } \\
\text { levemente }\end{array}$ & Neutro & $\begin{array}{l}\text { Concordo } \\
\text { levemente }\end{array}$ & Concordo & $\begin{array}{l}\text { Concordo } \\
\text { Fortemente }\end{array}$ \\
\hline 1 & 2 & 3 & 4 & 5 & 6 & 7 \\
\hline
\end{tabular}

7) Agente interno no papel de multiplicador da melhoria contínua.

Classifique numa escala de 1 a 7, onde 1 é discordo fortemente e 7 é concordo fortemente, a afirmação a seguir: "O agente interno consegue transformar ou mudar o comportamento de outras pessoas e fazê-las ter iniciativa para melhoria contínua." (ler a tabela abaixo). Após resposta solicite: Justifique e exemplifique.

\begin{tabular}{|l|l|l|l|l|l|l|}
\hline $\begin{array}{l}\text { Discordo } \\
\text { Fortemente }\end{array}$ & Discordo & $\begin{array}{l}\text { Discordo } \\
\text { levemente }\end{array}$ & Neutro & $\begin{array}{l}\text { Concordo } \\
\text { levemente }\end{array}$ & Concordo & $\begin{array}{l}\text { Concordo } \\
\text { Fortemente }\end{array}$ \\
\hline 1 & 2 & 3 & 4 & 5 & 6 & 7 \\
\hline
\end{tabular}


ANEXO 2 - Roteiro de entrevista do gestor

Bom dia / Boa tarde. Obrigado antecipadamente pela sua disponibilidade. Como nos falamos anteriormente o objetivo desta entrevista é a compreensão do processo de capacitação dos agentes internos de melhoria. A duração prevista será de 45 minutos a 2 horas, de acordo com a sua disponibilidade. Nenhuma informação revelada será documentada com nomes, títulos ou códigos conhecidos de pessoas ou empresas. Podemos gravar a nossa conversa?

1) Caracterização do entrevistado.

Para começar, gostaria que você me descrevesse sua idade, escolaridade e alguma experiência prévia com o tema melhoria contínua, se existir.

2) Processo de capacitação

a. Qual(is) foi(ram) o propósito(s) de contratação da consultoria? Justifique e exemplifique.

b. Quais foram as atividades e respectivo tempo (desde a identificação do profissional a ser treinado até o acompanhamento do término de projeto)? Justifique e exemplifique.

c. O que deveria ter sido conduzido ou feito de forma diferente? Justifique e exemplifique.

3) Expectativa sobre a continuidade com novos projetos.

Classifique numa escala de 1 a 7 , onde 1 é discordo fortemente e 7 é concordo fortemente, a afirmação a seguir: "É esperado que, após a conclusão de sua capacitação, cada profissional passe a identificar e realizar projetos de melhoria para atingir objetivos de desempenho e resolver problemas crônicos, transformando-se num efetivo agente interno de melhoria contínua." (ler a tabela abaixo). Após resposta solicite: Justifique e exemplifique.

\begin{tabular}{|l|l|l|l|l|l|l|}
\hline $\begin{array}{l}\text { Discordo } \\
\text { Fortemente }\end{array}$ & Discordo & $\begin{array}{l}\text { Discordo } \\
\text { levemente }\end{array}$ & Neutro & $\begin{array}{l}\text { Concordo } \\
\text { levemente }\end{array}$ & Concordo & $\begin{array}{l}\text { Concordo } \\
\text { Fortemente }\end{array}$ \\
\hline 1 & 2 & 3 & 4 & 5 & 6 & 7 \\
\hline
\end{tabular}


4) Estrutura do programa de melhoria e Papeis.

4.1) Como foi estruturado o programa, em termos de papeis e responsabilidades?

4.2) Como foi acordada a definição de cada um destes papeis?

4.3) Descreva o papel teórico (esperado ou definido como ideal) e percepções sobre o seu cumprimento na prática:

a. Alta direção: Atitude e Conhecimento do Método

b. Coordenador de Melhoria Continua: Atitude e Conhecimento do Método

c. Gestores dos agentes internos de melhoria contínua (seu papel): Atitude e Conhecimento

d. Agentes internos de melhoria contínua: Atitude e Conhecimento do Método

e. Outros papeis: Atitude e Conhecimento do Método esperados

5) Resultados.

Descreva os resultados alcançados nos projetos de melhoria inicial (projetos realizados durante o processo de capacitação dos agentes internos sob sua responsabilidade)

6) Agentes internos altamente engajados com o programa de melhoria.

Identifique agentes internos que foram altamente engajados com o programa de melhoria contínua. Comente sobre os critérios utilizados para esta classificação.

7) Continuidade com novos projetos.

Classifique numa escala de 1 a 7 , onde 1 é discordo fortemente e 7 é concordo fortemente, a afirmação a seguir: "Os agentes internos capacitados continuaram a implantar projetos de melhoria de forma sistemática, mesmo após o término da capacitação inicial. " (ler a tabela abaixo). Após responder, justifique e estime uma porcentagem de agentes treinados que continuaram a implantar novos projetos de melhoria.

\begin{tabular}{|l|l|l|l|l|l|l|}
\hline $\begin{array}{l}\text { Discordo } \\
\text { Fortemente }\end{array}$ & Discordo & $\begin{array}{l}\text { Discordo } \\
\text { levemente }\end{array}$ & Neutro & $\begin{array}{l}\text { Concordo } \\
\text { levemente }\end{array}$ & Concordo & $\begin{array}{l}\text { Concordo } \\
\text { Fortemente }\end{array}$ \\
\hline 1 & 2 & 3 & 4 & 5 & 6 & 7 \\
\hline
\end{tabular}

7.1) Que fatores pessoais e/ou organizacionais fizeram alguns agentes a continuar com a implantação de novos projetos de melhoria? 
7.2) Que fatores pessoais e/ou organizacionais fizeram alguns agentes a não iniciar e implantar novos projetos de melhoria? 
ANEXO 3 - Roteiro de entrevista do coordenador de melhoria continua

Bom dia / Boa tarde. Obrigado antecipadamente pela sua disponibilidade. Como nos falamos anteriormente o objetivo desta entrevista é a compreensão do processo de capacitação dos agentes internos de melhoria. A duração prevista será de 45 minutos a 2 horas, de acordo com a sua disponibilidade. Nenhuma informação revelada será documentada com nomes, títulos ou códigos conhecidos de pessoas ou empresas. Podemos gravar a nossa conversa?

1) Caracterização do entrevistado.

Para começar, gostaria que você me descrevesse sua idade, escolaridade e alguma experiência prévia com o tema melhoria contínua, se existir.

2) Processo de capacitação

a. Qual(is) foi(ram) o propósito(s) de contratação da consultoria? Justifique e exemplifique.

b. Quais foram as atividades e respectivo tempo (desde a identificação do profissional a ser treinado até o acompanhamento do término de projeto)? Justifique e exemplifique.

c. O que deveria ter sido conduzido ou feito de forma diferente? Justifique e exemplifique.

3) Continuidade com novos projetos.

Classifique numa escala de 1 a 7 , onde 1 é discordo fortemente e 7 é concordo fortemente, a afirmação a seguir: "É esperado que, após a conclusão de sua capacitação, cada profissional passe a identificar e realizar projetos de melhoria para atingir objetivos de desempenho e resolver problemas crônicos, transformando-se num efetivo agente interno de melhoria contínua." (ler a tabela abaixo). Após resposta solicite: Justifique e exemplifique.

\begin{tabular}{|l|l|l|l|l|l|l|}
\hline $\begin{array}{l}\text { Discordo } \\
\text { Fortemente }\end{array}$ & Discordo & $\begin{array}{l}\text { Discordo } \\
\text { levemente }\end{array}$ & Neutro & $\begin{array}{l}\text { Concordo } \\
\text { levemente }\end{array}$ & Concordo & $\begin{array}{l}\text { Concordo } \\
\text { Fortemente }\end{array}$ \\
\hline 1 & 2 & 3 & 4 & 5 & 6 & 7 \\
\hline
\end{tabular}


4) Estrutura do programa de melhoria e Papeis.

4.1) Como foi estruturado o programa, em termos de papeis e responsabilidades?

4.2) Como foi acordada a definição de cada um destes papeis?

4.3) Descreva o papel teórico (esperado ou definido como ideal) e percepções sobre o seu cumprimento na prática:

a. Alta direção: Atitude e Conhecimento do Método

b. Coordenador de Melhoria Continua: Atitude e Conhecimento do Método

c. Gestores dos agentes internos de melhoria contínua (seu papel): Atitude e Conhecimento

d. Agentes internos de melhoria contínua: Atitude e Conhecimento do Método

e. Outros papeis: Atitude e Conhecimento do Método esperados

5) Resultados.

Descreva os resultados alcançados nos projetos de melhoria inicial (projetos realizados durante o processo de capacitação dos agentes internos sob sua responsabilidade)

6) Gestores e agentes internos altamente engajados com o programa de melhoria.

Identifique gestores e agentes internos que foram altamente engajados com o programa de melhoria contínua. Comente sobre os critérios utilizados para esta classificação.

7) Continuidade com novos projetos.

Classifique numa escala de 1 a 7 , onde 1 é discordo fortemente e 7 é concordo fortemente, a afirmação a seguir: "Os agentes internos capacitados continuaram a implantar projetos de melhoria de forma sistemática, mesmo após o término da capacitação inicial. " (ler a tabela abaixo). Após responder, justifique e estime uma porcentagem de agentes treinados que continuaram a implantar novos projetos de melhoria.

\begin{tabular}{|l|l|l|l|l|l|l|}
\hline $\begin{array}{l}\text { Discordo } \\
\text { Fortemente }\end{array}$ & Discordo & $\begin{array}{l}\text { Discordo } \\
\text { levemente }\end{array}$ & Neutro & $\begin{array}{l}\text { Concordo } \\
\text { levemente }\end{array}$ & Concordo & $\begin{array}{l}\text { Concordo } \\
\text { Fortemente }\end{array}$ \\
\hline 1 & 2 & 3 & 4 & 5 & 6 & 7 \\
\hline
\end{tabular}

7.1) Que fatores pessoais e/ou organizacionais fizeram alguns agentes a continuar com a implantação de novos projetos de melhoria? 
7.2) Que fatores pessoais e/ou organizacionais fizeram alguns agentes a não iniciar e implantar novos projetos de melhoria? 
ANEXO 4 - Roteiro de entrevista do consultor externo

Bom dia / Boa tarde. Obrigado antecipadamente pela sua disponibilidade. Como nos falamos anteriormente o objetivo desta entrevista é a compreensão do processo de capacitação dos agentes internos de melhoria. A duração prevista será de 45 minutos a 2 horas, de acordo com a sua disponibilidade. Nenhuma informação revelada será documentada com nomes, títulos ou códigos conhecidos de pessoas ou empresas.

$\mathrm{O}$ mesmo roteiro será aplicado novamente para cada uma das montadoras $(\mathrm{A}, \mathrm{B}, \mathrm{C})$ que o consultor participou do processo de capacitação. Podemos gravar a nossa conversa?

1) Caracterização do entrevistado.

Para começar, gostaria que você me descrevesse sua idade, escolaridade e experiência na consultoria e treinamentos ligados a programas de melhoria contínua.

2) Processo de capacitação

a. Qual(is) foi(ram) o propósito(s) de contratação da consultoria? Justifique e exemplifique.

b. Quais foram as atividades e respectivo tempo (desde a identificação do profissional a ser treinado até o acompanhamento do término de projeto)? Justifique e exemplifique.

c. O que deveria ter sido conduzido ou feito de forma diferente? Justifique e exemplifique.

3) Estrutura do programa de melhoria e Papeis.

3.1) Como foi estruturado o programa, em termos de papeis e responsabilidades?

3.2) Como foi acordada a definição de cada um destes papeis?

3.3) Descreva o papel teórico (esperado ou definido como ideal) e percepções sobre o seu cumprimento na prática:

a. Alta direção: Atitude e Conhecimento do Método

b. Coordenador de Melhoria Continua: Atitude e Conhecimento do Método

c. Gestores dos agentes internos de melhoria contínua (seu papel): Atitude e Conhecimento 
d. Agentes internos de melhoria contínua: Atitude e Conhecimento do Método

e. Outros papeis: Atitude e Conhecimento do Método esperados

\section{4) Resultados.}

Descreva, de forma geral, sua percepção sobre os resultados alcançados nos projetos de melhoria inicial (projetos realizados durante o processo de capacitação dos agentes internos)

5) Gestores e agentes internos altamente engajados com o programa de melhoria.

Identifique gestores e agentes internos que foram altamente engajados com o programa de melhoria contínua. Comente sobre os critérios utilizados para esta classificação. 